RAFAEL ALVES DA SILVA

\title{
SUBÚRBIO S/A: \\ reestruturação imobiliária e reconfiguração do espaço urbano carioca sob domínio do capital financeiro no século XXI
}

Exemplar revisado e alterado em relação à versão original, sob responsabilidade do autor e anuência da orientadora. A versão original, em formato digital, ficará arquivada na Biblioteca da Faculdade.

São Paulo, 21 de maio de 2019.

Dissertação apresentada ao Programa de PósGraduação da Faculdade de Arquitetura e Urbanismo da Universidade de São Paulo para obtenção do título de Mestre em Arquitetura e Urbanismo

Área de Concentração: Planejamento Urbano e Regional Orientadora: Prof. a . Dra. Maria Beatriz Cruz Rufino 
Autorizo a reprodução total ou parcial deste trabalho, por qualquer meio convencional ou eletrônico, para fins de estudo e pesquisa, desde que citada a fonte.

Assinatura:

Data 03/03/2019

e-mail:rfl.alvs@gmail.com

\section{FICHA TÉCNICA:}

\section{Paula Cardoso Moreira \\ Mapas}

\section{Luiza Amoroso}

Edição de imagens

\section{Jeferson Felix}

Foto da capa

\section{Elizabeth Othon}

Tradução do resumo

Catalogação na Publicação

Serviço Técnico de Biblioteca

Faculdade de Arquitetura e Urbanismo da Universidade de São Paulo

Silva, Rafael Alves da

Subúrbio S/A: reestruturação imobiliária e reconfiguração do espaço urbano carioca sob domínio do capital financeiro no século XXI / Rafael Alves da Silva; orientadora Maria Beatriz Cruz Rufino. - São Paulo, 2019.

$173 \mathrm{f}$.

Dissertação (Mestrado) - Faculdade de Arquitetura e Urbanismo da Universidade de são Paulo. Área de

concentração: Planejamento Urbano e Regional.

1. Produção do Espaço. 2. Reestruturação Imobiliária. 3. Financeirização. 4. Subúrbio Carioca. I. Rufino, Maria Beatriz Cruz, orient. II. Título. 
FOLHA DE APROVAÇÃO|

RAFAEL ALVES DA SILVA

\begin{abstract}
SUBÚRBIO S/A:
reestruturação imobiliária e reconfiguração do espaço urbano

carioca sob domínio do capital financeiro no século XXI
\end{abstract}

\begin{abstract}
Dissertação apresentada ao Programa de Pós-
Graduação da Faculdade de Arquitetura e Urbanismo da Universidade de São Paulo para obtenção do título de Mestre em Arquitetura e Urbanismo
\end{abstract}

Aprovado em: 12/04/2019

COMISSÃO JULGADORA:

Orientadora: Prof. a Dra. Maria Beatriz Cruz Rufino

Instituição: FAU-USP

Julgamento: Aprovado

Prof. ${ }^{a}$ Dra. Beatriz Bezerra Tone

Instituição: FAU-USJT

Julgamento: Aprovado

Prof. ${ }^{a}$ Dra. Cristina Lontra Nacif

Instituição: EAU-UFF

Julgamento: Aprovado 
Esta dissertação é dedicada à memória de Marielle Franco e Anderson Gomes; à memória dos mais de 300 trabalhadores brasileiros assassinados pela Vale em Brumadinho (MG); à memória de Evaldo Rosa dos Santos, o Manduca, assassinado com 80 tiros em Guadalupe pelo exército brasileiro; à memória do Museu Nacional; e, por fim, a todos os suburbanos e suburbanas que sobrevivem ao caos carioca às costas do Redentor 


\section{Agradecimentos}

Em especial, à Prof. ${ }^{a}$ Beatriz Rufino, orientadora querida, pelo acolhimento na FAU, pela dedicação a este trabalho e por ajudar a manter a calma nos momentos difíceis. Mas também por todo o aprendizado, pelas orientações estimulantes e por colocar as questões necessárias quando eu achava que já tinha as respostas.

Ao Prof. Paulo César X. Pereira pelas conversas provocativas e instigantes ao longo desse processo, pelo rigor teórico e metodológico e pela cooperação nos rumos desta dissertação.

À Prof. a Luciana Royer pelas importantes trocas nos debates em suas aulas e por mostrar que nas divergências teóricas a gente também evolui o pensamento crítico.

À Prof. ${ }^{a}$ Isabel Alvarez pela importante interlocução em suas aulas na FFLCH.

Aos colegas do grupo de pesquisa "Incorporação Imobiliária e Metropolização" Hudynne Lima e Artur Paulani pelas importantes trocas durante o período da pesquisa.

À amiga Paula Cardoso Moreira pela elaboração dos mapas que compõem esta dissertação e pela motivação de sempre.

Ao Lucas Faulhaber pela disponibilização de dados que compõem parte desta dissertação.

Aos amigos Richard Lins, Ivan Zanatta e Luciana Ximenes pela importante interlocução durante todo este processo e também pelos papos de botequim nas idas ao Rio.

À Cristina Nacif, Sonia Ferraz e Juarez Duayer, grande exemplo de professores e a quem sempre serei grato pelos bons tempos de EAU-UFF.

Aos amigos que a pós-graduação me deu: João Volpato, Rérisson Máximo, Lyzandra Martins, Maria Pia, Guilherme Braz, Julia Murad, Isadora Borges, Bruno Avellar e Anselmo Bastos. Sem vocês este percurso teria sido mais penoso e menos divertido.

À Beth, Fefa e Caê, amigas com quem construo cotidianamente um lar cheio de plantas em São Paulo, a nossa Angelingrado.

Aos amigos Felipe Guimarães, Karol Perbiche, Maicon Bezerra e Leticia Pereira por, mesmo de longe, se manterem sempre presentes nesta fase de grandes transformações.

A meu pai e aos meus irmãos - Débora, Felipe e Samuel - por todo apoio e torcida.

À minha sobrinha Lili pelo amor que transborda. 
À minha mãe: amiga e companheira de tantas batalhas que a vida nos impôs. Que nas dores e delícias sempre esteve a meu lado me incentivando. Esta dissertação também é por você! À Luiza pelo carinho, dedicação, compreensão e apoio; por sempre ser o cais no decorrer de toda essa travessia. 
A árvore quando é cortada Chora e sofre de tal maneira Pois vê que o machado que sangra o seu tronco Também é feito de madeira Trovoada, El Efecto. 


\section{RESUMO |}

Título: Subúrbio S/A: reestruturação imobiliária e reconfiguração do espaço urbano carioca sob domínio do capital financeiro no século XXI

As transformações na produção do espaço urbano carioca a partir da primeira década do século XXI, protagonizada pela produção das grandes incorporadoras do setor imobiliário sob domínio do capital financeiro, conformam o objeto de análise desta dissertação.

O que se observa no período estudado é que o urbano tem sido levado às últimas consequências enquanto lócus privilegiado de reprodução ampliada do capital. Portanto, lançar olhar sobre essas transformações nos permite compreender como o imbricamento entre o capital financeiro e o imobiliário, expandindo suas fronteiras de acumulação, engendrou uma verdadeira "explosão" de novos empreendimentos de mercado, reconfigurando o espaço das metrópoles a partir da atuação privilegiada do setor. O resultado desse processo, como mostraremos, foi o encarecimento insano do preço das propriedades imobiliárias e, com isso, a intensificação dos processos de espoliação.

Pretende-se analisar como o Estado atua nessas transformações articulado às frações financeira e imobiliária do capital, seja pela alteração de marcos regulatórios, na promoção de políticas públicas ou na construção de grandes infraestruturas, desempenhando a função de viabilizar as condições gerais de produção e garantir a ampliação da acumulação do setor.

Neste cenário, o subúrbio da Zona Norte carioca despontou como foco de todos esses investimentos que reforçam as transformações em curso, onde a produção de seu espaço torna-se a manifestação mais acabada desse processo.

Palavras-chaves: produção do espaço; reestruturação imobiliária; financeirização; capitalização; subúrbio 


\begin{abstract}
|
Title: Suburb S/A: Real Estate Restructuring and Reconfiguration of the Rio de Janeiro Urban Space under the Domain of Financial Capital in the 21st Century
\end{abstract}

The transformations in the production of the urban space of Rio de Janeiro since the first decade of the XXI century, led by the production of great developers of the real estate sector under the domain of the financial capital, make up the object of analysis of this dissertation. What has been observed in the studied period is that the urban space has been taken to ultimate consequences as a privileged locus of expanded reproduction of capital. Therefore, look up at these transformations allows us to understand how the imbrication between financial capital and real estate, expanding its accumulation boundaries, engendered a real "explosion" of new ventures for the market sector, reconfiguring the metropolitan space from the privileged performance of the sector. The result of this process, as will be shown, was the outrageous increase in the price of real estate properties, and with this, the reinforcement of spoliation processes.

It is intended to analyze how the State operates in these transformations associated with financial and real estate fractions of capital, either by changing regulatory frameworks, promoting public policies or building large infrastructures, fulfilling the role that sets up the general conditions of production and ensures the expansion of the sector's accumulation.

In this scenario, the suburb of the Northern Zone of Rio de Janeiro emerged as the focus of all these investments that enhance the ongoing transformations, where the production of its space becomes the most complete manifestation of this process.

Keywords: production of space; real estate restructuring; financialization; capitalization; suburb 


\section{SIGLAS E ABREVIATURAS |}

ADEMI - Associação de Dirigentes de Empresas do Mercado Imobiliário

AEIU - Área de Especial Interesse Urbanístico

AP - Área de Planejamento

BID - Banco Interamericano de Desenvolvimento

BNH - Banco Nacional de Habitação

BRT - Bus Rapid Transit

CBIC - Câmara Brasileira da Indústria da Construção

CCFGTS - Conselho Curador do Fundo de Garantia do Tempo de Serviço

CCB - Cédulas de Crédito Bancário

CCI - Cédulas de Crédito Imobiliário

CEF - Caixa Econômica Federal

CMN - Conselho Monetário Nacional

CRI - Certificado de Recebíveis Imobiliários

CVM - Comissão de Valores Mobiliários

FAR - Fundo de Arrendamento Residencial

FGTS - Fundo de Garantia do Tempo de Serviço

FII - Fundo de Investimento Imobiliário

FMI - Fundo Monetário Internacional

IPO - Initial Public Offering

LCI - Letra de Crédito Imobiliário

PAC - Programa de Aceleração do Crescimento

PDDUS - Plano Diretor de Desenvolvimento Urbano Sustentável do Município do Rio de Janeiro

PEU - Plano de Estruturação Urbana

PMCMV - Programa Minha Casa Minha Vida

SBPE - Sistema Brasileiro de Poupança e Empréstimo

SECOVI - Sindicato das Empresas de Compra, Venda, Locação e Administração de Imóveis

Residenciais e Comerciais

SFH - Sistema Financeiro de Habitação

SFI - Sistema Financeiro Imobiliário

SINDUSCON - Sindicato da Indústria da Construção Civil

SMU - Secretaria Municipal de Urbanismo da Prefeitura do Município do Rio de Janeiro 
SPE - Sociedade de Propósito Específico

UPP - Unidade de Polícia Pacificadora

VGV - Valor Geral de Vendas 


\section{LISTAGEM DE FIGURAS |}

Figura 1. LOCALIZAÇÃo DAS LiNHAS FÉRREAS NA ÁREA METROPOLITANA DO Rio DE JANEIRO ...7 FIGURA 2. EMPREENDIMENTOS FAIXA 1 DO PMCMV NO BAIRRO DE SANTA CRUZ (AP 5) .............91

FIGURA 3. CONDOMÍNIO BAIRRO CARIOCA NO BAIRRO DO ROCHA (AP 3) ...................................99

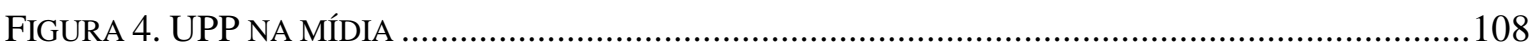

FIGURA 5. LOCALIZAÇÃO DAS UPPS NO MUNICÍPIO DO RIO DE JANEIRO .......................................109

FIGURA 6. IMPLANTAÇÃO DE NOVOS EMPREENDIMENTOS DE GRANDE PORTE NA ZONA NORTE ..136 FIGURA 7. IMPLANTAÇÃO DE NOVOS EMPREENDIMENTOS DE GRANDE PORTE NA ZONA NORTE ..137 FIGURA 8. EMPREENDIMENTO ESTAÇÃO ZONA NORTE, NO BAIRRO DA PAVUNA: JOINT VENTURE ENTRE A LIVING E A CURY 144 


\section{LISTAGEM DE MAPAS |}

MAPA 1. DIVISÃo TERRITORIAL POR ÁREAS DE PLANEJAMENTO (APS) DO MUNICÍPIO DO RIO DE

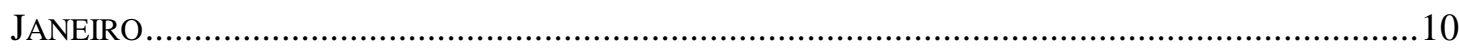

MAPA 2. EMPREENDIMENTOS LANÇADOS PELO PMCMV NO RIO DE JANEIRO (2009-2015)............95

MAPA 3. MACROZONEAMENTO DA CIDADE DO RIO DE JANEIRO - PDDUS 2011 _..............................98

MAPA 4. OCUPAÇÃO TERRITORIAL E VETORES DE CRESCIMENTO - PDDUS 2011 _...........................99

MAPA 5. BAIRROS ONDE OS PEUS FORAM INSTITUÍDOS OU QUE AINDA TRAMITAM NA CÂMARA 101

MAPA 6. VARIAÇÃO DA TAXA DE VALORIZAÇÃO (\%) DO PREÇO DOS IMÓVEIS NO MUNICÍPIO DO RIO

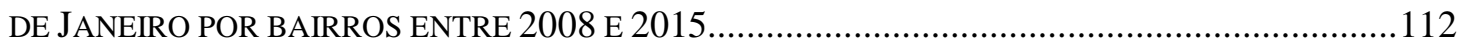

MAPA 7. EMPREENDIMENTOS LANÇADOS NO MUNICÍPIO DO RIO DE JANEIRO ENTRE 2007 E 2015: PORTE E PREÇO

MAPA 8. LANÇAMENTOS DOS EMPREENDIMENTOS DAS EMPRESAS QUE ABRIRAM CAPITAL A PARTIR DE 2005 NA CIDADE DO RIO DE JANEIRO POR PORTE (2000-2006). 130

MAPA 9. LANÇAMENTOS DOS EMPREENDIMENTOS DAS EMPRESAS DE CAPITAL ABERTO NA CIDADE

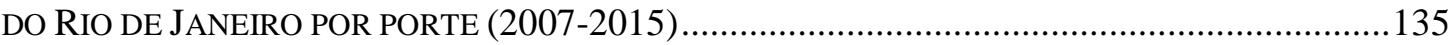

MAPA 10. LANÇAMENTOS DA CYRELA NA CIDADE DO RIO DE JANEIRO POR PORTE (2000-2006). 142

MAPA 11. LANÇAMENTOS DA CYRELA NA CIDADE DO RIO DE JANEIRO POR PORTE (2007-2015). 145

MAPA 12. LANÇAMENTOS DA MRV NA CIDADE DO RIO DE JANEIRO POR PORTE (2007-2015) ......150

MAPA 13. LANÇAMENTOS DA PDG NA CIDADE DO RIO DE JANEIRO POR PORTE (2000-2006) .......155

MAPA 14. LANÇAMENTOS DA PDG NA CIDADE DO RIO DE JANEIRO POR PORTE (2007-2015) .......157

MAPA 15. PREÇO MÉDIO DO M² NO MUNICÍPIO DO RIO DE JANEIRO POR BAIRROS (2015) 163 


\section{LISTAGEM DE TABELAS |}

TABELA 1. INCORPORADORAS BRASILEIRAS LISTADAS NA BOVESPA 66

TABELA 2. FUSÕES, AQUISIÇÕES E PARCERIAS REALIZADAS PELAS GRANDES INCORPORADORAS DE CAPITAL ABERTO .72

TABELA 3. ÁREAS LICENCIADAS NO MUNICÍPIO DO RIO DE JANEIRO (2009-2015). .88

TABELA 4. NÚMERO DE UNID. LICENCIADAS NO MUNICÍPIO DO RIO DE JANEIRO (2009-2015) .89

TABELA 5. ÁREA LICENCIADA TOTAL E TOTAL DE UNIDADES NO ENTORNO (500M DE RAIO) DE CADA estaÇão dos BRT TransOeste, TransCarioca, TransOlímpica, TransBrasil, LinHaS 1, 2 E 4 DO METRÔ E RAMAIS DA SUPERVIA (2009 A 2015) 105

TABELA 6. BAIRROS COM MAIORES VARIAÇÕES DA TAXA DE VALORIZAÇÃO 2008 E 2014 113

TABELA 7. PARTICIPAÇÃO DAS INCORPORADORAS DE CAPITAL ABERTO NO LANÇAMENTO DE NOVOS EMPREENDIMENTOS IMOBILIÁRIOS NA CIDADE DO RIO DE JANEIRO POR AP (2007-2015) ....138 TABElA 8. POSIÇÃo ACIONÁRIA DA CYRELA (2017). 141

TABELA 9. POSIÇÃO ACIONÁRIA DA MRV (2018) 148

TABELA 10. POSIÇÃo ACIONÁRIA DA PDG (2017) 153 


\section{LISTAGEM DE GRÁFICOS |}

GRÁFICO 1. NÚMERO DE UNIDADES LANÇADAS NO BRASIL POR INCORPORADORA (2005-2015)....67

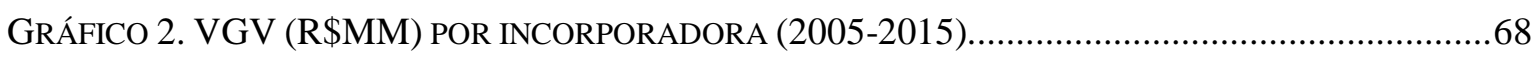

GRÁFICO 3. DISTRIBUIÇÃO GEOGRÁFICA DOS LANÇAMENTOS DA PDG (2007 E 2011) ....................73

GRÁFICO 4. DiSTRIBUIÇÃO GEOGRÁFICA DO LANDBANK DA MRV (2007-2014) ............................73

GrÁfICO 5. ÁreA LICENCIADA PELO PMCMV E NÚMERO DE UNIDADES LICENCIADAS PELO PMCMV POR ÁREA DE PLANEJAMENTO NO MUNICíPIO Do Rio DE JANEIRO (2009-2015) - \%

GRÁFICO 6. ÁREA LICENCIADA E NÚMERO DE UNIDADES LICENCIADAS POR FAIXA DE RENDA DO PMCMV NO MUNICÍPIO DO RIO DE JANEIRO (2009-2013) - \% . .94

GRÁFICO 7. VARIAÇÃO DA TAXA DE VALORIZAÇÃO IMOBILIÁRIA POR CIDADE (2008-2016).........116

GRÁFICO 8. FUSÕES E AQUISIÇÕES NO BRASIL (1985-2015) 117

GRÁFICO 9. UNIDADES RESIDENCIAIS LANÇADAS NA CIDADE DO RIO DE JANEIRO (1980- 2006).. 127

GRÁFICO 10. PARTICIPAÇÃO DO NÚMERO DE UNIDADES LANÇADAS NA CIDADE DO RIO DE JANEIRO POR ÁREA DE PLANEJAMENTO ENTRE 2000 E 2006 128

GRÁFICO 11. PARTICIPAÇÃO DO NÚMERO DE UNIDADES LANÇADAS NA CIDADE DO RIO DE JANEIRO POR ÁREA DE PLANEJAMENTO ENTRE 2007 E 2015 132

GRÁFICO 12. PARTICIPAÇÃO DAS INCORPORADORAS DE CAPITAL ABERTO NO LANÇAMENTO DE NOVOS EMPREENDIMENTOS IMOBILIÁRIOS DA CIDADE DO RIO DE JANEIRO (2007-2015) ......134

GRÁFICO 13. PARTICIPAÇÃO DAS INCORPORADORAS DE CAPITAL ABERTO NO LANÇAMENTO DE NOVOS EMPREENDIMENTOS IMOBILIÁRIOS NA AP 3: RIO DE JANEIRO (2007-2015) 138

GRÁFICO 14. TRAJETÓRIA DA CYRELA NA BOVESPA (2005-2016). 140

GRÁFICO 15. SÉRIE HISTÓRICA DE LANÇAMENTOS DA CYRELA POR SEGMENTO DE MERCADO NA RMRJ .145

GRÁFICO 16. TRAJETÓRIA DA MRV NA BOVESPA (2007-2016) 147

GRÁFICO 17. MRV: UNIDADES LANÇADAS POR ANO NO RIO DE JANEIRO (2007-2015) 149

GRÁFICO 18. TRAJETÓRIA DA PDG NA BOVESPA (2007-2016) 152

GRÁFICO 19. SÉRIE HISTÓRICA DE LANÇAMENTOS DA PDG POR SEGMENTO DE MERCADO 154

GRÁFICO 20. PDG: UNIDADES LANÇADAS POR ANO NO RIO DE JANEIRO (2007-2015) 156

GRÁFICO 21. VARIAÇÃO DA VALORIZAÇÃO (\%) DO PREÇO DOS IMÓVEIS NO RIO DE JANEIRO X PERFORMANCE DA BOVESPA ENTRE 2008 E 2015 160 
INTRODUÇÃO | . .9

CAPÍTULO 01 | A PRODUÇÃO DO ESPAÇO COMO ESTRATÉGIA DE REPRODUÇÃO DO CAPITAL: A PROPRIEDADE DA TERRA, FORMAS DE PRODUÇÃO E FINANCEIRIZAÇÃO . .16

1.1. A PROPRIEDADE DA TERRA COMO CAPITAL FICTíCIO: A RELAÇÃO ENTRE VALORIZAÇÃO E CAPITALIZAÇÃO NA PRODUÇÃO DO ESPAÇO 17

1.2. Formas DE PRODUÇÃo DO ESPAÇO E AVANÇO DA INCORPORAÇÃo IMOBILIÁRIA: A SUPERAÇÃO DO PADRÃO CENTRO X PERIFERIA.

1.3. FINANCEIRIZAÇÃO DA PRODUÇÃO DO ESPAÇO NA PERIFERIA DO CAPITALISMO: NOTAS SOBRE O CONTEXTO BRASILEIRO

CAPÍTULO 02 | A CONFLUÊNCIA ENTRE MERCADO FINANCEIRO, IMOBILIÁRIO E ESTADO NA FORMAÇÃO DE NOVAS FRONTEIRAS IMOBILIÁRIAS: MECANISMOS DE CAPITALIZAÇÃO 61

2.1. ABERTURA DE CAPITAL DAS GRANDES INCORPORADORAS E ESTRATÉGIAS GERAIS DO SETOR IMOBILIÁRIO.

2.2. A CONSTITUIÇÃO DE MECANISMOS JURÍDICO-FINANCEIROS DE CAPITALIZAÇÃO NO ÂMBITO NACIONAL . .78

2.3. A CONSTITUIÇÃO DE MECANISMOS SOCIOESPACIAIS DE CAPITALIZAÇÃO NO ÂMBITO LOCAL

CAPÍTULO 03 | REESTRUTURAÇÃo IMOBILIÁRIA E METROPOLIZAÇÃo DO ESPAÇO URBANO CARIOCA NO SÉCULO XXI: A INTENSIFICAÇÃO DOS PROCESSOS DE CAPITALIZAÇÃO, CENTRALIZAÇÃO DO CAPITAL E A EXPANSÃO DAS FRONTEIRAS DE ACUMULAÇÃO

3.1. AS ESTRATÉGIAS DE ATUAÇÃO DAS GRANDES INCORPORADORAS DE CAPITAL ABERTO NO RIO DE JANEIRO 126

CONSIDERAÇÕES FINAIS. 161

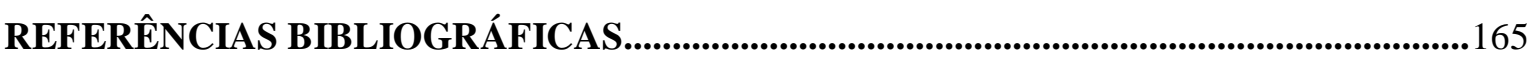




\title{
INTRODUÇÃO|
}

“- O sinal, de R $\$ 300$ mil, foi pago logo depois da visita ao apartamento. Mas enquanto a compradora começava a fazer planos para o seu novo lar, a vendedora ainda tinha dúvidas sobre o negócio. Tanto assim que adiou a entrega da documentação por cinco meses. Desconfiado, o corretor responsável pelo negócio foi pesquisar. O imóvel negociado a $R$ \$ 1,2 milhão, estava novamente à venda numa imobiliária concorrente. Só que por $\mathrm{R} \$ 1,68$ milhão, ou seja, $\mathrm{R} \$ 480$ mil a mais! Questionada, a vendedora sugeriu simplesmente devolver os R 300 mil pagos como sinal. (...) Ainda assim, com o novo negócio, lucrou $\mathrm{R} \$ 180 \mathrm{mil}$. E, por sorte do novo comprador, ela não desistiu da venda novamente.” - Extraído da reportagem "Histórias de uma Bolha", publicada em 21/08/2011 no caderno "Morar Bem" do jornal O Globo.

\begin{abstract}
“- Quero R\$ 800 mil.
- Eu pago!

- Fácil assim? Então, são R\$ 850 mil!

O diálogo parece surreal, e é, mas até bem pouco tempo o fato se repetia quase diariamente nas negociações entre comprador e vendedor. Era tanta mudança que os corretores acabavam perdendo bons negócios por conta do desejo de lucrar mais. Num caso ocorrido recentemente na Barra, um morador do Jardim Oceânico colocou seu apartamento à venda e pediu, a princípio, $\mathrm{R} \$ 800$ mil. A primeira proposta veio tão rapidamente, que ele resolveu aumentar o preço, em R\$ 50 mil. Recebeu a segunda proposta, e de novo, subiu o valor: pediu outros R\$50 mil. A venda só se concretizou quando o apartamento atingiu R\$ 1 milhão. Apenas quatro meses depois do primeiro anúncio." - Extraído da reportagem "Histórias de uma Bolha", publicada em 21/08/2011 no caderno "Morar Bem” do jornal O Globo.
\end{abstract}

\footnotetext{
“- Na orla do Rio, você não encontra mais imóveis de 200 a $300 \mathrm{~m}^{2}$ por menos de R\$ 7 milhões. No Leblon, já foi vendido apartamento com vista para o mar por $\mathrm{R} \$ 32$ milhões, lembra a diretora comercial da Concal, Bianca Carvalho, acrescentando que os preços estão surpreendendo os estrangeiros." - Extraído da reportagem "Os preços dos Imóveis no Rio e de Grandes Cidades Mundo Afora”, publicada em 11/11/2011 no caderno "Economia" do jornal O Globo.
}

\footnotetext{
“- O mercado estava maluco e cresceu numa progressão que deixou muita gente enlouquecida. Mas o Rio precisava desta valorização, pois estava com os preços muito descolados dos praticados em outras áreas cobiçadas do exterior. Nós somos a bola da vez, devido não apenas a toda riqueza natural e histórica da cidade, como também aos Jogos Olímpicos que estão por vir. Agora, os preços tendem a sofrer os reajustes normais. A tendência é de estabilização" - Extraído da reportagem "Os preços dos Imóveis no Rio e de Grandes Cidades Mundo Afora", publicada em 11/11/2011 no caderno "Economia" do jornal O Globo.
} 

s diálogos anteriores foram extraídos de reportagens de $O$ Globo, jornal de maior circulação do município do Rio de Janeiro, realizadas no ano de 2011. À época, os principais meios de comunicação anunciavam com grande entusiasmo as transformações em curso. Dentre elas, o "aquecimento" do mercado imobiliário devido aos ares "olímpicos" que pairavam na cidade, quase sempre sustentadas na ideia de "aproveitar as oportunidades que os Jogos estão dando para transformar a cidade". Assim, as primeiras inquietações que deram origem à presente pesquisa se originaram na esteira desses processos. Chamava ainda mais atenção o fato de toda essa pujança acontecer pouco tempo após uma crise econômica de grandes proporções que impactou diversas nações pelo mundo e que ficou conhecida popularmente como crise financeira mundial (subprimes) deflagrada no ano de 2008. Em contrapartida, como resposta à crise que inevitavelmente chegaria ao Brasil, o governo federal lança em 2009 uma política econômica anticíclica travestida de política habitacional - o Programa Minha Casa Minha Vida - que financiaria de imediato, como de fato financiou, a construção de um milhão de novas unidades habitacionais só na sua primeira fase e outras milhões nas fases seguintes. No processo dessas reflexões, duas questões saltavam aos olhos: uma parte considerável dos países no mundo estavam afundadas numa profunda recessão econômica devido à "bolha imobiliária" que desencadeou tal crise nos Estados Unidos e que, num efeito dominó, foi “quebrando" as economias de outros países (principalmente na Europa). Para se ter uma ideia, no ano em que a crise foi desencadeada, cerca de 850 mil famílias norte americanas perderam suas casas para os bancos devido ao não pagamento de suas hipotecas. Na cidade de Detroit (EUA), casas eram colocas a venda por poucos dólares ${ }^{1}$. De maneira inversa, as cidades brasileiras experimentavam um expressivo aumento nos preços imobiliários no mesmo período. Em janeiro de 2012, poucos meses após as reportagens citadas de $O$ Globo, os imóveis cariocas se "valorizaram" 255\% em relação a janeiro de 2008, alcançando, em 2015, o patamar de $360 \%$. Além disso, era visível a proliferação de novos empreendimentos imobiliários de mercado pelo urbano brasileiro e que, na atualidade, tinham algo de particular: essa expansão imobiliária através da forma incorporação que historicamente se limitava à promoção de empreendimentos de "médio" e "alto" padrões nas áreas mais nobres das cidades, passa a diversificar sua produção para expandir as fronteiras de acumulação em direção às chamadas

\footnotetext{
1 "Em Detroit, casas vendidas a US\$1". Publicada em 08/03/2010 no caderno Geral do Estadão:
} https://www.estadao.com.br/noticias/geral,em-detroit-casas-vendidas-a-us-1,520972 
periferias urbanas. Foram a partir dessas observações que se iniciou nossa investigação teórica.

\section{Objeto}

A partir disso, o presente trabalho propõe enquanto objeto de análise, as transformações ocorridas na produção do espaço do subúrbio da cidade do Rio de Janeiro a partir de meados da primeira década do século XXI em decorrência da intensificação da produção imobiliária realizada, em sua maior parte, pelas grandes incorporadoras nacionais de capital aberto, buscando compreender como o imbricamento entre parte do setor imobiliário e mercado financeiro reconfiguraram o espaço da metrópole carioca e transformaram o espaço suburbano num lugar privilegiado para reprodução ampliada do capital.

$\mathrm{Na}$ contemporaneidade, a produção social do espaço adquire novos contornos e especificidades à medida que as relações sociais capitalistas se desenvolvem. Nessa lógica, a produção imobiliária de mercado ganha relevância enquanto forma de produção mais avançada do ponto de vista da acumulação capitalista se sobrepondo a precariedades históricas sem, no entanto, superá-las. Antes o contrário: as intensifica pela fragmentação que esse processo impõe. De imediato, é necessário compreender a transformação sistêmica pela qual o modo de produção capitalista vem atravessando desde a década de 1970, quando as finanças passam a ser centrais na condução do sistema e, consequentemente, passam a impactar todos os níveis das relações sociais e cotidianas, inclusive o urbano. Este fenômeno que emerge desta transformação do próprio modo de acumulação é conhecido como financeirização, um conceito em disputa pelos mais diversos estudos das mais variadas correntes teóricas, mas que aqui é compreendida como um fenômeno social; uma transformação sistêmica do capitalismo, ainda que mantenha seu fundamento; um continuum evolutivo do modo de acumulação. Para Chesnais (2005), "o mundo contemporâneo apresenta uma configuração específica do capitalismo, na qual o capital portador de juros está localizado no centro das relações econômicas e sociais"2. Dessa forma, o autor também adverte que o capital financeiro sempre teve um papel importante para o funcionamento do sistema capitalista enquanto credor ao adiantar capital na forma de empréstimo para o setor produtivo. O que muda na atualidade é que esse capital se autonomiza e se desloca para o

\footnotetext{
${ }^{2}$ CHESNAIS, 2005, p. 35
} 
quadro acionário e conselho das empresas onde investe seu capital, influenciando diretamente na organização, estratégias e rumos das mesmas, ainda que se mantenha uma posição de exterioridade ao processo produtivo.

Nesse contexto, todo o espaço social passa a ser mobilizado lucrativamente sob domínio das finanças. Esse imbricamento entre imobiliário (dimensão socioespacial) e financeiro (dimensão socioeconômica) intensificou a produção do espaço das cidades brasileiras a partir de meados da primeira década do século XXI, no momento em que as grandes incorporadoras nacionais se vincularam ao capital financeiro mundial decorrente da abertura de capital na bolsa de valores. Esse movimento culminou numa acelerada expansão de novos empreendimentos imobiliários em várias cidades brasileiras - sobretudo nas metrópoles para espaços menos valorizados, não raro precários, onde historicamente esse mercado não atuava. Lefebvre ([1972] 1999) aponta como a partir da década de 1970, a mobilização do espaço pelo capital deu sobrevida à acumulação. Segundo o autor,

\begin{abstract}
o setor imobiliário se torna tardiamente, mas de maneira cada vez mais nítida, um setor subordinado ao grande capitalismo, ocupado por suas empresas (industriais, comerciais, bancárias), com uma rentabilidade cuidadosamente organizada sob a cobertura da organização do território. O processo que subordina as forças produtivas ao capitalismo se reproduz aqui, visando à subordinação do espaço que entra no mercado para investimento dos capitais. (LEFEBVRE, [1972] 1999, pp. 163-164)
\end{abstract}

Contudo, esse processo no contexto brasileiro possui especificidades que remetem à atuação do Estado na criação de uma série de mecanismos para garantir a reprodução ampliada do capital a partir do imobiliário, desde a criação de novos marcos regulatórios que garantam a intensificação da propriedade imobiliária enquanto mercadoria fictícia e a segurança jurídica para os investidores no âmbito nacional e até mesmo políticas urbanas locais e provisão de infraestruturas, como ocorreu no Rio de Janeiro nos últimos 12 anos.

Devido a seu papel de destaque na economia nacional, o Rio de Janeiro emerge como referência concreta de tais processos de transformações ocorridas na produção do espaço das metrópoles brasileiras no período, com especial destaque à expansão da produção imobiliária para subúrbio da Zona Norte da cidade. Essa região da cidade tornou-se então lugar privilegiado para atuação dessas grandes incorporadoras de capital aberto, consolidando-se como nova fronteira de acumulação de capital.

Vale mencionar que o título da dissertação - SUBÚRBIO S/A: reestruturação imobiliária e reconfiguração da metrópole carioca sob domínio do capital financeiro no século XXI - faz 
menção a um tipo de sociedade empresarial constituída a partir de capital dividido em ações conhecida como Sociedade Anônima de capital aberto. O título ganhou força no decorrer das análises realizadas no trabalho quando se observou que as transformações decorrentes do processo de reestruturação imobiliária no território suburbano carioca tiveram participação, na maior parte dos casos, das empresas incorporadoras de capital aberto no lançamento de novos empreendimentos imobiliários, conforme será mostrado no terceiro capítulo e em dados que podem ser observados ao longo do texto e peças gráficas.

\section{O subúrbio como ideologia: uma aproximação socioespacial}

A realidade suburbana do Rio de Janeiro vem se modificando ao longo do tempo desde o período colonial, passando pela acelerada urbanização que tem nos ramais da ferrovia seu principal condutor, até a atualidade, período no qual procuramos dedicar nossos esforços nesta dissertação. Assim, o conceito carioca da categoria espacial subúrbio "sobrevive nos mais diferentes discursos, sejam eles críticos ou não, seja ciência ou poesia"3. Cabe inicialmente fazer uma aproximação desse objeto espacial que perpassa todo este trabalho, conferindo-lhe alguma especificidade através das pistas deixadas pela própria evolução urbana da cidade. Para isso, nos aprofundaremos na obra $O$ Rapto Ideológico da Categoria Subúrbio do geógrafo Nelson Fernandes, que dedicou boa parte de suas pesquisas a compreender todos os aspectos sociais e ideológicos que permeiam esse espaço no contexto da metrópole carioca.

Destarte, Fernandes (2011) argumenta que o conceito carioca da categoria socioespacial "subúrbio" sofreu, ao longo da história da cidade, um rapto ideológico 4 . O marco desta mudança abrupta de significado origina-se, segundo o autor, nas reformas urbanísticas empreendidas por pelo então prefeito Pereira Passos a partir de 1903 inspiradas na reforma de Paris lideradas pelo Barão de Haussmann ${ }^{5}$. Não por acaso, as reformas inauguraram um

\footnotetext{
${ }^{3}$ FERNANDES, 2011, p. 160

${ }^{4}$ Segundo o autor, a noção de rapto ideológico de categorias sociais e espaciais foi exposta por Lefebvre. Nesse sentido, Fernandes ressalta que "podemos entender o rapto ideológico como uma mudança brusca e drástica do significado de categorias e conceitos, quando então os atributos mais originais e essenciais que o definiam são expurgados de seu conteúdo e substituídos por significados novos e completamente estranhos à sua extração mais genuína" (FERNANDES, 2011, p. 16)

${ }^{5}$ Em sua obra intitulada Paris, Capital da Modernidade (2015), David Harvey aponta que as reformas de Paris dirigidas por Haussmann no século XIX vão muito além de uma nova configuração espacial - arquitetônica e urbanística - para a cidade. As reformas marcam um processo de ruptura que engendra a modernidade industrial, transformando profundamente as relações socioespaciais, a cultura e costumes na cidade.
} 
processo de produção desigual do espaço urbano carioca à feição das relações sociais capitalistas. "O Estado, visto aqui em sua instância municipal, deu início a um novo processo de exploração da força de trabalho, comandado agora diretamente por ele e de natureza estritamente espacial”'. Até este momento, o conceito de subúrbio utilizado no Rio de Janeiro representava seu sentido original, a saber, os espaços fora da cidade, ainda que subordinados a ela, com urbanização bastante incipiente e caracterizado pelas habitações de caráter hedônico das classes médias e altas do período. Com a Reforma Passos, a área passou ser caracterizada de forma pejorativa nos mais variados discursos, uma vez que o subúrbio carioca se expandiu enquanto espaço de moraria proletária.

A partir de um regate acerca do conceito de subúrbio na história da sociedade, Fernandes (2011) tem por objetivo compreender como, desde a antiguidade até a cidade moderna, o subúrbio tem várias interpretações diferentes, revelando a polissemia desses lugares, bem como seus aspectos invariantes. No contexto urbano-industrial do século XX, o autor recorre à obra O Direito à Cidade ([1968] 2010) de Henri Lefebvre, para compreender a ocupação socioespacial de Paris no século XIX, especialmente no que tange ao conceito de ideologia do habitat. $\mathrm{O}$ autor francês aponta que a ideologia do habitat foi uma estratégia bem-sucedida para conquista parisiense no século XIX e reconhece que tal estratégia tinha como característica a moralização da classe proletária enquanto proprietários imobiliários.

No entanto, é necessário entender como, no Rio de Janeiro, a categoria subúrbio ganha novo significado a partir do início do século XX. Foi a partir da obra da geógrafa Maria Segada Soares que, já na década de 1950, observou a existência de um significado particular do conceito de subúrbio no cotidiano carioca. A autora notou que havia uma discrepância entre o significado histórico e geográfico da palavra com aquele praticado no Rio de Janeiro. Posteriormente, outros pesquisadores cariocas que se debruçaram sobre o estudo desse espaço, "sempre tiveram a preocupação em explicar que não estavam se referindo à periferia da cidade, mas aos bairros populares e ferroviários situados dentro do território municipal e da área urbana da cidade" ${ }^{\text {7 }}$. Além disso, ressaltavam a particularidade do emprego da palavra no caso do Rio, diferenciando-a da forma como é aplicada nos Estados Unidos e Europa, normalmente associada às classes médias e altas.

\footnotetext{
${ }^{6}$ ABREU, 1987, p. 17

${ }^{7}$ Ibid., p. 34
} 
Fernandes (2011) aponta duas características importantes que diferencia o modo como o subúrbio é retratado no Rio de Janeiro pois, diferentemente do sentido original do termo que tem como aspecto invariante a sua posição periférica ao longo do tempo, há, no caso do Rio, a "perda no sentido locacional e espacial"8. O outro aspecto que caracteriza o conceito no Rio de Janeiro é a associação instantânea que se faz entre os ramais ferroviários e bairros populares. Essa relação entre ferrovia e subúrbio é tão forte que não se denomina subúrbio as áreas onde o trem não possui influência. Além disso, há que se constatar a não utilização do conceito para designar os espaços ocupados pelas classes médias e altas, ainda que geograficamente ocupem áreas "afastadas" do núcleo central. É o caso da Barra da Tijuca.

Figura 1. Localização das linhas férreas na Área Metropolitana do Rio de Janeiro

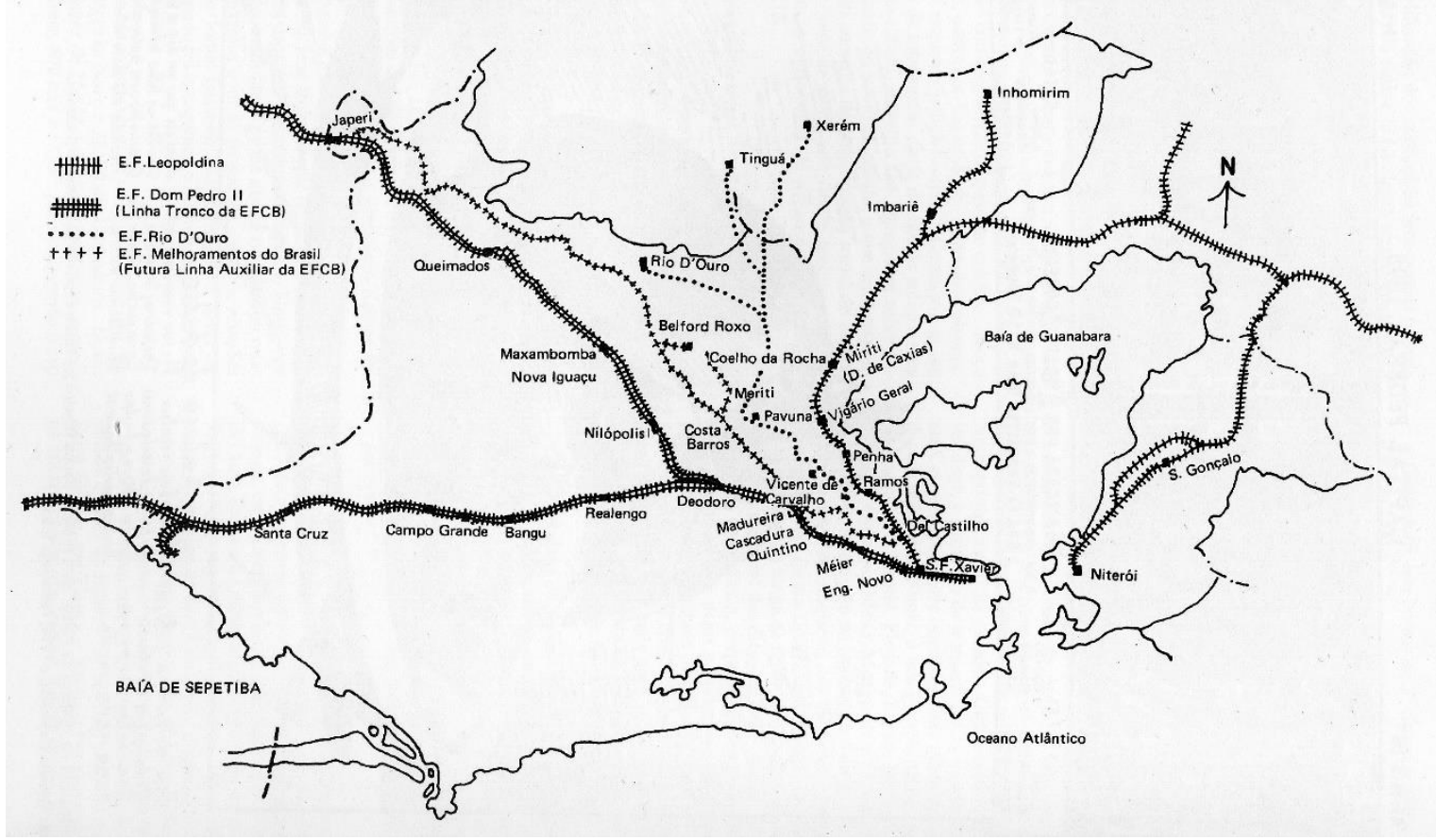

Fonte: ABREU, 2008

É importante ressaltar que até o início do século XX quando o conceito de subúrbio guardava seu significado original, os bairros da Zona Sul eram enquadrados na categoria subúrbio. Copacabana, Ipanema e Leblon são os exemplos mais notáveis. Essa situação muda quando a marcha urbanizadora promovida pela elite carioca em aliança com o Estado ocupa essas áreas com seus palacetes e, posteriormente, com seus edifícios multifamiliares. A própria Barra da Tijuca, a partir da sua massiva ocupação na década de 1980 promovida pela incorporação imobiliária e pelo Estado para abrigar as classes média e alta em grandes

\footnotetext{
${ }^{8}$ Ibid., p. 34
} 
condomínios fechados, rapidamente foi incorporada ao núcleo metropolitano, apesar da sua posição periférica na cidade. Segundo Fernandes,

\begin{abstract}
"tal juízo nos leva à conclusão que, de fato, há uma espécie de veto à imaginação no que tange à existência de subúrbios de classes abastardas no Rio de Janeiro. É a classe social que determina o que é subúrbio, a geografia não importa, a tal ponto de a posição excêntrica e francamente suburbana da Barra da Tijuca ser vista como um acidente, algo fora dos nossos padrões e difícil de ser admitido" (FERNANDES, 2011, p.36, grifo nosso).
\end{abstract}

A palavra subúrbio transformou-se então em sinônimo de desprestígio social e de bairros proletariados assistidos pela linha ferroviária. Diferente do exposto por Lefebvre acerca da ideologia do habitat no contexto parisiense, a ocupação dos espaços "periféricos" da cidade do Rio de Janeiro não teve um sentido moralizante para a classe trabalhadora. Além disso, essa ocupação se deu, na maioria dos casos, à própria sorte dos trabalhadores a partir da produção doméstica ou através da provisão habitacional via Estado. Esse fato, inclusive é o que consolidou a expansão das favelas e loteamentos privados, com precária infraestrutura, em todo território da cidade, extrapolando seus limites e formando o que se compreende hoje como Região Metropolitana do Rio de Janeiro (RMRJ). Por fim, entende-se que o significado da categoria subúrbio no Rio de Janeiro, como explicitado por Fernandes (2011), envolve diretamente as relações entre espaço e ideologia, representando uma forma de consciência do espaço de uma determinada época e cultura.

Sob essa perspectiva, é recorrente a dificuldade em se definir e limitar o que é subúrbio nos estudos sobre a cidade do Rio de Janeiro. Isso ocorre pelo caráter essencialmente simbólico do conceito. Seus limites são imprecisos, variáveis ao longo do tempo de acordo com a evolução urbana da cidade e não se baseia no tradicional e nem no legal, mas na difusa consciência social, como resume o geógrafo suburbano.

$\mathrm{Na}$ atualidade, a apreensão dos limites do subúrbio no Rio de Janeiro se mostra ainda mais difícil. O Plano Diretor de Desenvolvimento Sustentável do Município do Rio de Janeiro lançado em 2011, por exemplo, constitui uma nova delimitação interna do município a partir de Macrozonas de Ocupação e também de Áreas de Planejamento. Essas duas demarcações, embora guardem semelhanças em alguns espaços, não se compatibilizam totalmente. Há, ainda, a divisão tradicional da cidade por Zonas - Centro, Sul, Norte e Oeste - que, embora se mantenha viva no linguajar cotidiano dos moradores da cidade como forma de localização, caiu em certo desuso pelo poder municipal, aparecendo de maneira genérica no texto legal do último Plano. Para aumentar a complexidade da questão, soma-se a isso o 
imaginário popular acerca da categoria subúrbio enquanto pertencimento, costumes e cultura específica: neste caso, o subúrbio extrapola os limites político-administrativos do município do Rio de Janeiro. É habitual encontrar pessoas residentes em municípios da Baixada Fluminense ou até mesmo de outros que compõem a RMRJ, como São Gonçalo e Itaguaí, que se identificam enquanto moradores do subúrbio ou, simplesmente, suburbanos. Quem vai dizer que não são?

Para fins puramente didáticos visando facilitar a interlocução e a compreensão do recorte espacial que aqui se estabelece, ainda que esta dissertação compartilhe da visão postulada por Nelson Fernandes acerca da categoria subúrbio enquanto ideologia, compreendendo a categoria subúrbio como processo e com nenhuma pretensão de delimitar definitivamente o que é o subúrbio no Rio de Janeiro, nos atreveremos a fazer uma delimitação virtual. Quando houver menção ao subúrbio, estaremos nos referindo tão somente aos bairros da Zona Norte e Oeste da cidade, com exceção aos bairros que compõem a Baixada de Jacarepaguá ${ }^{9}$. Para ser ainda mais específico, valendo-se das divisões postas no último Plano Diretor, referemse aos bairros da AP 3 e AP 5, ainda que o objeto espacial deste trabalho esteja nos limites da AP 3 que, por sua vez, também será denominada Zona Norte Suburbana. O mapa a seguir ilustra bem essa divisão.

\footnotetext{
${ }^{9}$ Segundo dados da Secretaria Municipal de Urbanismo da Prefeitura do Município do Rio de Janeiro (SMU), compõem a Baixada de Jacarepaguá os seguintes bairros: Jacarepaguá, Anil, Gardênia Azul, Cidade de Deus, Curicica, Freguesia, Pechincha, Taquara, Praça Seca, Tanque, Joá, Barra da Tijuca, Itanhangá, Camorim, Vargem Grande, Vargem Pequena, Recreio dos Bandeirantes e Grumari
} 
Mapa 1. Divisão territorial por Áreas de Planejamento (APs) do município do Rio de Janeiro

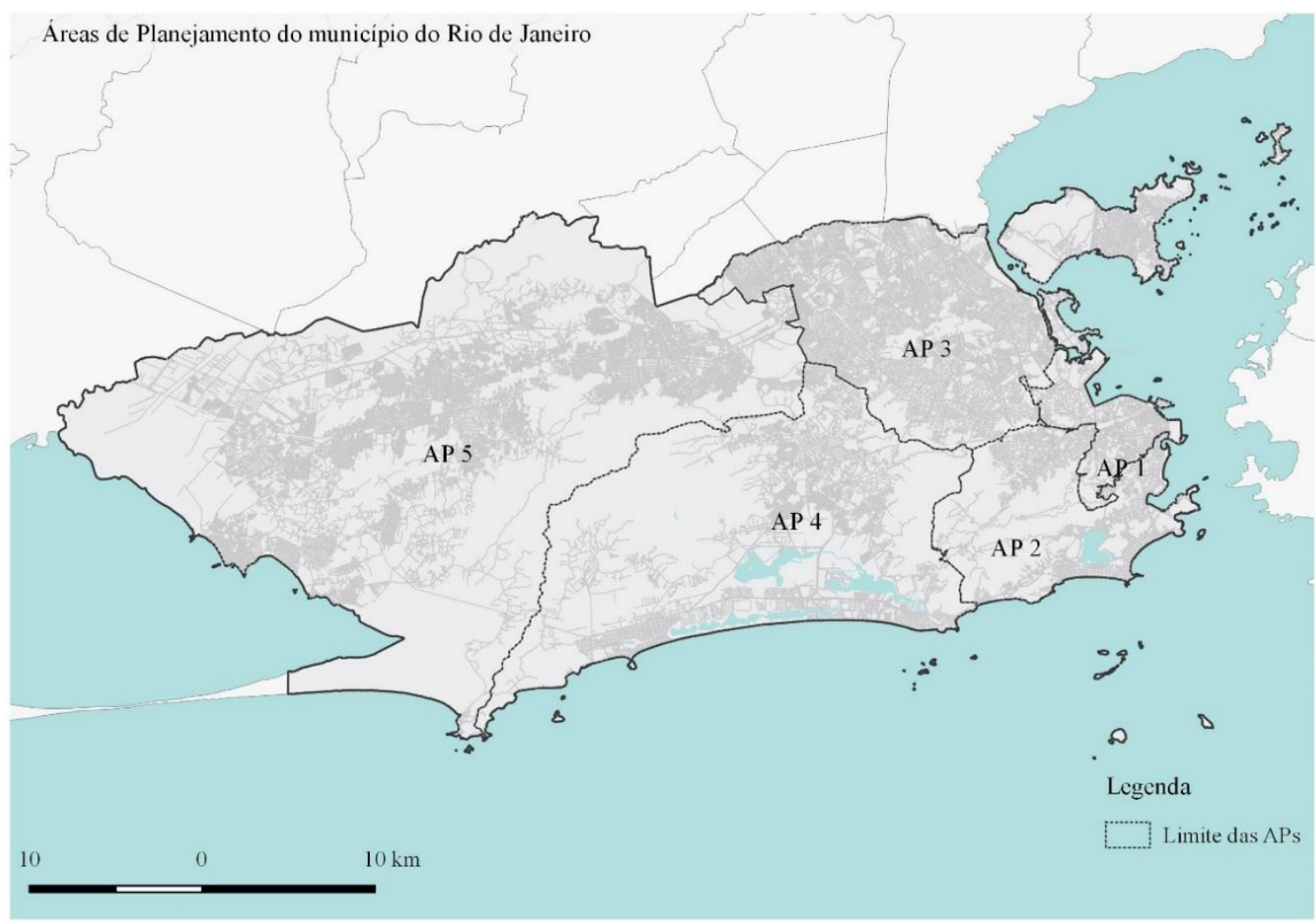

Fonte: elaboração do autor a partir de dados do PDDUS/2011

\section{Objetivos}

O objetivo geral da pesquisa é:

- Compreender o impacto das transformações ocorridas a partir de meados da década de 2000 na produção do espaço metropolitano do Rio de Janeiro decorrentes do processo de reestruturação imobiliária conduzido pelas grandes incorporadoras nacionais associadas ao capital financeiro, tendo como recorte espacial a Zona Norte do subúrbio carioca.

Os objetivos específicos da pesquisa são:

- Analisar do ponto de vista teórico como, no atual regime de acumulação capitalista financeiro, a propriedade imobiliária intensifica-se enquanto capital fictício;

- Explorar a ideia de superação do padrão de estruturação urbana centro x periferia, bastante consolidada nos estudos urbanos sobre o Rio de Janeiro, a partir do conceito de formas de produção do espaço, buscando analisar o espaço urbano enquanto totalidade; 
- Compreender as novas características da produção do espaço na contemporaneidade a partir da chave de análise que conecta o imobiliário (dimensão socioespacial) com o financeiro (dimensão socioeconômica) tendo em vista as especificidades do contexto brasileiro;

- Apreender como se estabelece a coalização entre mercado financeiro, o imobiliário e o Estado na conformação de um novo patamar de acumulação a partir da produção do espaço no contexto brasileiro e, mais especificamente, na metrópole carioca;

- Compreender como o Estado, em seus diferentes níveis, viabiliza as condições gerais de produção e dá garantias para reprodução ampliada do capital a partir de mecanismos de capitalização, como a instituição de novos marcos regulatórios financeiros e financiamento de políticas habitacionais no âmbito global e de políticas públicas de segurança, provisão de novas infraestruturas e flexibilização de parâmetros urbanísticos, no âmbito local.

- Analisar a integração das incorporadoras brasileiras à dinâmica do capital financeiro, compreendendo que a financeirização do imobiliário no Brasil tem particularidades fundamentais que rementem à atuação do Estado e à própria especificidade das relações capitalistas na sociedade brasileira, bem como os movimentos estratégicos na produção imediata (inserção, escala, relação com infraestruturas, tipologias) das grandes incorporadoras de capital aberto estudadas que atuam na Zona Norte suburbana;

\section{Metodologia}

A pesquisa divide-se em dois grandes grupos que se relacionam durante o decorrer do trabalho, a saber, o de investigação teórica de caráter abstrato associado ao levantamento, sistematização e análise crítica de dados concretos sobre o objeto e o problema de pesquisa. Dentro do primeiro grupo, se propôs o aprofundamento em bibliografias que dão aporte teórico e contextualização histórica necessários para a compreensão do objeto num contexto global, ou seja, a partir das questões fundamentais que conformam as relações sociais capitalistas, não perdendo de vista as mediações necessárias com as especificidades da formação social latino-americana e, particularmente, a brasileira. São textos que fornecem os conceitos-base da pesquisa e chaves de análise crítica dentro do tema da produção do espaço na sociedade capitalista, como as questões formuladas por Marx ([1865] 2013; [1894] 2017) acerca da teoria do valor, da distribuição global do mais-valor e moderna propriedade 
da terra enquanto capital fictício e que foram retomadas e atualizadas por Lefebvre ([1970] 1999; [1972] 1999; e [1972] 2008) e Harvey (2013). Recorremos também à obra de Martins (1979) para compreender as especificidades da formação da moderna propriedade privada da terra no Brasil a partir da Lei de Terras de 1850. As obras de Pereira (1988) e de Tone (2015), apoiadas também nas obras de Marx, contribuem para uma melhor compreensão da intensificação da relação fetichizada entre preço e valor no atual regime de acumulação financeiro, bem como a compreensão da formação dos preços no imobiliário que tem na capitalização da renda o seu fundamento.

Apropria-se da obra de Chesnais (2005) para compreender o domínio das finanças em todas as esferas das relações sociais na atualidade. Nesse sentido, a obra de Amaral (2012) e Paulani (2012), nos ajuda a compreender os desdobramentos do domínio das finanças num contexto de uma economia capitalista dependente, como é o caso brasileiro, cuja inserção econômica no mundo atual se estabelece enquanto uma plataforma de valorização financeira. Ainda sobre as obras já citadas de Lefebvre, é a partir delas que são lançadas as bases para a compreensão de como o espaço passa a ser mobilizado lucrativamente pelo capital para a reprodução ampliada do capital. Os trabalhos de Rufino (2012), Lencioni (2017) e de Pereira (2017) ajudam a compreender o imbricamento do imobiliário e o financeiro na atualidade, onde a propriedade da terra se intensifica enquanto capital fictício, tornando os preços das propriedades imobiliárias e dos aluguéis cada vez mais insanos e, com isso, reforçando processos de espoliação.

Dentro de nossa investigação teórica utilizou-se também um conjunto de bibliografias mais recentes que abordam a forma incorporação no contexto brasileiro do século XXI, onde grandes as grandes incorporadoras se articulam ao mercado financeiro e também ao Estado em suas diferentes esferas para garantir a expansão da produção imobiliária em larga escala Brasil afora. As pesquisas de Royer (2009), Fix (2011), Shimbo (2012), Rufino (2012) e Sanfelici (2013) ajudam a esclarecer o tema. Ainda dentro do mesmo tema, mas destacando as transformações ocorridas nas periferias metropolitanas, recorremos às pesquisas de Volochko (2015).

A Aproximação do território carioca é feita por diferentes entradas. O trabalho de Fernandes (2011) contribuiu para compreender como se constituiu o conceito de subúrbio na cidade do Rio de Janeiro ao longo do século XX. A contribuição teórica de Ribeiro (1997) discute a formação, expansão e consolidação da forma incorporação na cidade do Rio de Janeiro, bem 
como o avanço das fronteiras imobiliárias. Recentemente, o trabalho de Faulhaber (2016) avança esse debate no contexto do capital financeiro no século XXI no Rio de Janeiro, compreendendo também a estratégias das grandes incorporadoras e sua coalizão política com o Estado.

Já no segundo grupo, realizou-se uma aproximação com toda a produção imobiliária de mercado da cidade do Rio de Janeiro, dando enfoque à produção das grandes incorporadoras nacionais de capital aberto, que captaram um grande montante recursos via mercado financeiro e também tiveram uma atuação expressiva na cidade, não só pela grande quantidade de empreendimentos lançados, Valores Gerais de Vendas (VGVs), mas também pelos seus portes e impacto nos distintos espaços da cidade. Levando em conta a produção, as estratégias de atuação no Rio de Janeiro, trajetória e estrutura acionária, optou-se por aprofundar os estudos sobre as seguintes incorporadoras: PDG, Cyrella e MRV. Estas incorporadoras destacaram-se, segundo nossas análises, no hall das maiores incorporadoras nacionais, e passaram a concentrar a maior parte de sua produção na metrópole carioca justamente no espaço da Zona Norte suburbana, onde historicamente não atuavam.

A pesquisa empírica apoiou-se fundamentalmente nos dados levantados pela ADEMI Rio (Associação de Dirigentes de Empresas do Mercado Imobiliário) e SMU (Secretaria Municipal de Urbanismo) sobre a análise da produção imobiliária no município do Rio de Janeiro entre os anos de 2000-2006 e 2007-2015 a partir de informações sobre a localização dos empreendimentos, porte (número de unidades), preço médio por unidade, incorporadora promotora e tipos de financiamento, dando ênfase a uma análise mais minuciosa na área estudada. Esses dados foram correlacionados considerando o estabelecimento de relações dessa produção com as infraestruturas já existentes (Metrô Linha 2, ramais ferroviários da Supervia e principais vias expressas) e as criadas recentemente (corredores BRTs e obras de infraestrutura), bem como a relação com as Unidades de Polícia Pacificadora (UPPs), visando a compreensão do impacto desse conjunto de empreendimentos no espaço suburbano. Outros dados complementares sobre o tema foram levantados em outras associações patronais vinculadas ao mercado imobiliário como a ABRAINC, CBIC, SECOVI e o SINDUSCON e na imprensa especializada a partir de entrevistas com agentes do setor. Para realização dessas análises, foi utilizado uma ferramenta digital de georreferenciamento - o QGIS, software livre de sistema de informação geográfica (SIG) que permite a visualização, edição e análise de dados georreferenciados - com o intuito de 
espacializar e dar clareza através dos diversos mapas produzidos ao movimento de expansão da produção imobiliária, facilitando as correlações com outros dados importantes como infraestrutura, espacialização das políticas públicas e instrumentos urbanísticos que compõem a legislação local. Outras ferramentas de análise como tabelas e gráficos, além de fotografias reforçam e dão sustentação aos argumentos apresentados nesta dissertação.

O processo de análise dos resultados se consolidou a partir do levantamento, organização, sistematização e correlação dos dados e outros materiais levantados, abordados à luz dos conceitos e aportes teóricos relacionados na bibliografia base desta pesquisa, através de uma análise crítica das múltiplas escalas socioespaciais que medeia a totalidade dos processos globais, ou seja, os aspectos que são comuns e essenciais ao fenômeno, ao mesmo tempo em que se explicita suas particularidades numa escala de análise mais imediata. Em seguida, fazendo o caminho inverso, dialeticamente, tenta-se analisar as especificidades à luz dos processos globais. Esta forma de análise se dá de maneira contínua durante toda a elaboração da pesquisa, correlacionando os aspectos teóricos e abstratos aos empíricos e mais concretos, buscando apreender a dinâmica do movimento real do objeto de pesquisa e captar sua essência.

\section{Estrutura da dissertação}

A dissertação divide-se em três capítulos. O primeiro é dedicado a discutir as características fundamentais do modo de produção capitalista e sua relação com a produção do espaço, atentando para as particularidades do imobiliário. Nesse sentido, é importante compreender como a instituição da moderna propriedade da terra faz com que a este elemento natural funcione como capital fictício a partir da relação dialética entre os processos de valorização e capitalização. Na contemporaneidade, esses processos se tornam mais fetichizados e se intensificam à medida que a terra passa a ser mobilizada também enquanto patrimônio rentista a partir das finanças.

No capítulo dois, daremos destaque às articulações entre capital financeiro, imobiliário e Estado em suas mais variadas escalas (do global ao local) e arranjos entre si, buscando compreender o papel de cada agente na criação de mecanismos que intensificam a capitalização da propriedade imobiliária na produção do espaço do subúrbio do Rio de 
Janeiro a partir do processo de reestruturação ocorrido a partir da segunda metade da década de 2000.

No terceiro e último capítulo, abordaremos as transformações socioespaciais (homogeneização, fragmentação e hierarquização) decorrentes do processo de reestruturação imobiliária no território suburbano carioca a partir das estratégias de atuação das grandes incorporadoras de capital aberto. Esta reestruturação tem no domínio do capital financeiro, na metropolização do espaço e na centralização do capital no imobiliário suas características fundamentais. 


\section{CAPÍTULO 01 |}

A produção do espaço como estratégia de reprodução do capital: a propriedade da terra, formas de produção e financeirização 
Este capítulo inicial tem por objetivo discutir os fundamentos estruturantes do modo de produção capitalista e sua relação com o espaço enquanto condição, meio e produto apoiados na relação que se estabelece entre os processos de valorização e capitalização. $O$ setor imobiliário possui características particulares frente a outros ramos produtivos, uma vez que o produto imobiliário se encrava à terra, um bem natural que não possui valor, mas que, enquanto mercadoria, adquire um preço. Na contemporaneidade, quando a emergência do imobiliário se imbrica com a esfera financeira mundializada, esses processos se intensificam e se tornam mais fetichizados à medida que a terra também passa a ser mobilizada como propriedade mobiliária.

\subsection{A propriedade da terra como capital fictício: a relação entre valorização e capitalização na produção do espaço}

As investigações teóricas empreendidas neste item começam por compreender como a instituição da moderna propriedade da terra e sua introdução no circuito de trocas no seio das relações sociais capitalistas como uma mercadoria especial, monopolizável, alienável e inerente a qualquer atividade humana - seja para exploração e extração ou até mesmo como espaço onde se desenvolve a produção -, passa a ser mobilizada como capital fictício. Interessa saber também como esta característica da terra enquanto propriedade, ou seja, inserida no modo de produção capitalista, torna-se mais patente na contemporaneidade, onde a atual forma de acumulação predominantemente financeira incide e se imbrica com a produção do imobiliário.

Para tanto, recorreremos às ideias de Marx a partir da obra $O$ Capital e às contribuições de outros autores filiados à corrente marxista como Lefebvre ([1972] 1999; [1972] 2008), Harvey (2013), Pereira (1988; 2017) e Tone (2015), sobre a questão da moderna propriedade da terra à luz da relação dialética entre valor e preço. O resgate da teoria do valor e sua atualização se revela, portanto, central para a compreensão de tal relação na produção do espaço contemporânea sob hegemonia da acumulação financeira, onde os processos de exploração e espoliação para sua reprodução são cada vez mais acentuados. 
Segundo Marx ([1867] 2013), toda a riqueza origina-se da terra e do trabalhador. Desde os primeiros indícios da vida humana no planeta, o homem interagiu com a natureza modificando-a teleologicamente, ou seja, a natureza sempre foi objeto do trabalho humano para seus devidos fins e condição primeira para toda a produção de infinitos valores de uso visando a satisfação de suas necessidades. Isso é, portanto, uma relação a-histórica. Porém, na sociedade de relações capitalistas, onde a riqueza é representada pela forma-mercadoria, os valores de uso, além de se constituírem como "conteúdo material da riqueza, (...) [se] constituem, ao mesmo tempo, os suportes materiais do valor de troca" ${ }^{10}$. Para Harvey, essa concepção universal da relação entre o homem e a terra "só é útil na medida em que indica as condições que o capital deve enfrentar ou modificar. $\mathrm{O}$ valor de uso da terra e de seus pertences tem de ser considerado em relação ao modo de produção capitalista"11.

Para se compreender como a terra passa a ser precificada na sociedade capitalista e a construção de uma teoria a respeito, deve-se, antes de tudo, se compreender uma categoria central do pensamento marxiano: o valor. Marx reconstitui a crítica desta categoria, examinando seu desenvolvimento a partir das ideias dos teóricos da Economia Política clássica, de inspiração burguesa, desde o século XVII. As interpretações dessa categoria continuam sendo debatidas e disputadas por diversas correntes do pensamento ainda nos dias de hoje. Traçaremos aqui, de forma concisa, a trajetória desse pensamento ${ }^{12}$ até a forma mais acabada da teoria do valor em Marx.

Diferentemente da fragmentação das ciências na contemporaneidade, a Economia Política clássica se pretendeu enquanto ciência voltada para uma análise globalizante da sociedade de sua época, preocupada com a totalidade da vida econômica e social, incentivada a solucionar os problemas para um novo e complexo sistema de relações sociais (capitalista) e formular uma teoria científica nova que fornecesse respostas aos anseios da nova classe social em ascensão: a burguesia. Nesse sentido, Lefebvre (2008) aponta que a Economia Política se apresentava enquanto ciência da produção.

\footnotetext{
${ }^{10}$ MARX, [1867] 2013, p. 114

${ }^{11}$ HARVEY, 2013, p. 431

${ }^{12}$ A trajetória do pensamento da Economia Política clássica descritas neste trabalho, levando em consideração as contribuições da escola mercantilista, dos fisiocratas franceses, de Adam Smith e David Ricardo, se basearam nos escritos de Marx em sua obra "Teorias da Mais-Valia". Pretende-se aqui apenas dar um breve panorama dos pontos que foram fundamentais para as formulações teóricas de Marx acerca do valor. Para maiores esclarecimentos, consultar a obra supracitada.
} 
Marx reconhecia a validade científica elaborada pelos principais expoentes da Economia Política clássica e seus avanços, inclusive partindo delas para consolidar uma teoria nova. Contudo, não deixou de apontar as inconsistências teóricas e seus respectivos conteúdos ideológicos em cada autor, que nem sempre encararam de frente à questão da origem do valor, pois precisavam justificar ideologicamente a necessidade de um modo de produção centrado na exploração do trabalho e na apropriação privada dos lucros. "Explicá-la, significava, em última instância, captar a essência do modo como a riqueza era produzida e transformada em excedente para acumulação" ${ }^{13}$. Nas palavras de Marx:

\begin{abstract}
A economia vulgar, com efeito, não faz mais que interpretar, sistematizar e louvar doutrinariamente as concepções dos agentes presos dentro das relações burguesas de produção. Não nos deve surpreender, portanto, que ela, precisamente na forma de manifestação alienada das relações econômicas, nas quais essas aparecem, prima facie, como contradições totais e absurdas - e toda a ciência seria supérflua se a forma de manifestação e a essência das coisas coincidissem imediatamente -, se sinta aqui perfeitamente à vontade e que essas relações lhe apareçam tanto mais naturais quanto mais escondida se encontrar nela a correlação interna, ao mesmo tempo em que são correntes para a concepção comum. (MARX, [1894] 2017, p. 880)
\end{abstract}

Com o aumento da produção na sociedade mercantil no século XVII, a categoria do trabalho toma um protagonismo cada vez maior nos debates. Dentre os pensadores da chamada Escola Mercantilista, o inglês William Petty (1623-1687) é quem dá um passo à frente na contribuição para os primeiros apontamentos para uma teoria do valor baseada no trabalho, ainda que de forma imprecisa (neste momento, os pensadores mercantilistas estavam preocupados com a defesa de um comércio internacional e o entesouramento de metais preciosos - em especial o ouro -, pois entendiam serem estas as bases de toda riqueza). Em linhas gerais, o autor diz haver uma distinção "entre preço natural, preço político e verdadeiro preço de mercado. Por preço natural entende na realidade o valor, (...) uma vez que da determinação do valor depende a determinação da mais-valia*"14. Em sua obra, Petty determina, de fato, o valor das mercadorias pela quantidade de trabalho nelas contida, sem distinguir, porém, a espécie de trabalho, importando apenas o tempo de trabalho. Isso fica explícito nessa passagem de sua obra:

"Se uma pessoa para levar a Londres uma onça de prata extraída do Peru precisar do mesmo tempo que empregaria para produzir um bushel de trigo,

\footnotetext{
${ }^{13}$ COSTA e MORAES, 1984 , p. 94

${ }^{14}$ MARX, Vol. 1, 1980, p. 343, grifos do autor

* No decorrer do texto, será adotada a expressão "mais-valor". Será mantida a expressão "mais-valia" apenas nos casos onde as citações a tragam desta forma, mantendo sua integridade. A expressões "mais-valor e "maisvalia" possuem o mesmo significado, variando de acordo com a tradução.
} 
então uma mercadoria é o preço natural da outra; se a mesma pessoa, com a exploração de novas e mais ricas minas, obtiver duas onças de ouro, com mesmo esforço empregado anteriormente para obter uma, o preço do trigo de 10 xelins por bushel será tão barato, agora, quanto antes o preço de 5 xelins, desde que não variem as demais condições" (p. 31). "Admitamos exija a produção de um bushel de trigo tanto trabalho quanto a de uma onça de prata' (p. 66)" (PETTY, W., apud MARX, Vol. 1, 1980, p. 343, grifos do autor)

Diferente dos fisiocratas franceses, Petty não compactuava com a ideia de que a renda fundiária era um "dom natural". Trabalhava essa ideia associada ao valor-trabalho e à produção agrícola, levando em consideração a localização das terras e o trabalho aplicado a terras com mesma fertilidade. A partir de suas ideias que, mais a frente, David Ricardo vai consolidar uma teoria sobre a renda diferencial. Porém, como Marx mesmo observa, seu pensamento se aproximava dos fisiocratas quando dizia que há duas formas de excedente (lucro): "a renda da terra ou a renda em dinheiro (juro). Deriva a segunda da primeira. Para ele, e mais tarde para os fisiocratas, a primeira é a forma genuína da mais-valia"15.

Na segunda metade do século XVII, consolidam-se algumas concepções teóricas onde a produção agrícola se torna uma questão central. A chamada escola fisiocrata nasce no bojo dos trabalhos de orientação naturalística. Passam, então, a analisar a economia não mais pela ótica da circulação, mas da produção. Interessava-lhes a análise empírica dos elementos constitutivos do funcionamento econômico, a fisiologia da economia, independentemente de considerações acerca do papel do Estado ou da vontade dos indivíduos. Tratava-se de descobrir e enunciar as "leis naturais" de uma ordem econômica capaz de regular a si própria. Com certa simplicidade, os fisiocratas estabeleceram uma teoria onde o valor de uso e a geração natural de excedentes são centrais. Porém, Marx adverte que os fisiocratas apenas reproduziam a visão de seu contexto histórico. Segundo ele:

\footnotetext{
"Não se pode censurar os fisiocratas por terem, como todos os seus sucessores, considerado como capital estes modos materiais de existência, instrumentos, matérias-primas etc., separados das condições sociais em que aparecem na produção capitalista, ou seja, na forma em que genericamente são elementos do processo de trabalho, dissociados da forma social, erigindo assim o modo de produção capitalista em modo eterno e natural de produção. (...) tiveram eles o mérito de considerá-las formas fisiológicas da sociedade: formas oriundas da necessidade natural da própria produção, independentemente da vontade, da política, etc. São leis materiais; o erro estava apenas em ver na lei material de determinado estádio social histórico, uma lei abstrata que rege por igual todas as formas sociais" (MARX, Vol. 1, 1980, p. 19)
}

${ }^{15}$ Ibid., p. 344 
Os fisiocratas defendiam a ideia de que só a agricultura cria um novo valor, sendo o único setor produtivo de fato e de onde se cria excedente. Para eles, a indústria e o comércio são atividades onde ocorrem apenas uma transferência ao produto do valor das matérias-primas e do trabalho, não havendo criação de novo valor, apenas modificação da matéria. A "produtividade, esse nível de produtividade donde se parte como condição prévia, tem de existir, antes de tudo, no trabalho agrícola, (...) e assim aparece como dom, como força produtiva da natureza"16

Apesar de serem os responsáveis pela virada que se tem da concepção do valor tirando-a da circulação e levando-a para produção, Marx expõe os limites e contradições dos estudos produzidos pelos mercantilistas e fisiocratas, sem deixar de reconhecer suas respectivas contribuições. A crítica está centrada em suas concepções limitadas de que o valor está nas propriedades físicas ou naturais do bem, no apego ao valor de uso e à ideia de que existe apenas trabalho concreto. Além disso, Marx critica o que chama de concepção metafísica do valor contida nessas análises, pois entendem que a mais-valia é sempre resultado de uma “ordem natural” do sistema econômico.

Os estudos de Economia Política sobre a origem do valor mudam de patamar com a obra do escocês Adam Smith (1723-1790), pensador bastante recorrido, ainda hoje, pelas suas ideias acerca da livre-concorrência determinada pelas forças do mercado e pela variação dos preços em função da lei da oferta e da procura. Smith defendia que o trabalho é a medida real do valor de troca de todas as mercadorias. Segundo o autor, "o trabalho, por nunca variar seu próprio valor, é a única medida real e definitiva que, em todos os tempos e lugares, pode ser utilizada para estimar e comparar o valor de todas as mercadorias" ${ }^{17}$. Acreditava, ainda, na existência de um preço natural, definido pela "soma das taxas naturais dos salários, lucro e renda" 18 . Foi um dos primeiros a observar que "o grande desenvolvimento real das forças produtivas só começa quando este se transforma em trabalho assalariado" ${ }^{19}$. Dizia também que os salários, lucro e renda são determinados pelas taxas comuns ou médias, influenciada pela oferta e procura de trabalho, capital e terra.

Quanto à origem do mais-valor, Smith diz que, no capitalismo, o fato de alguns indivíduos conseguirem realizar uma certa acumulação de capital, torna-os aptos a adquirir meios

\footnotetext{
${ }^{16}$ Ibid., p. 24

${ }^{17}$ SMITH, A. apud Ibid., p. 55

${ }^{18}$ Ibid., p. 74

${ }^{19}$ Ibid., p. 48
} 
materiais para a produção e a contratar trabalho alheio, pago em salário "com o fim de obter lucro mediante a venda do produto resultante ou com o que o trabalho delas tiver acrescentado ao valor daquelas matérias-primas" ${ }^{20}$. Nesse caso, o trabalho total incorporado ao produto divide-se, ao final da produção, em duas partes: uma que representa o salário e outra que constitui o lucro. Para Smith, o lucro é apenas uma dedução natural do produto do trabalho. De qualquer modo, será sempre o trabalho a verdadeira medida do valor, onde o capitalista, por sua vez, se apropria de uma quantidade a mais trabalho realizado e não pago (mais-valor). O lucro, portanto, será o equivalente à parcela de trabalho não pago. Para Marx, nesse ponto, Smith revela a verdadeira origem da mais-valor.

Contudo, o mais-valor, para Smith, não se dá apenas na forma de lucro, mas também como renda fundiária. Os proprietários de terras aparecem em seus escritos como um contraponto do trabalho. Representam um papel de total passividade na produção, "cuja atividade consiste unicamente em explorar o progresso do desenvolvimento social, para o qual nada contribui e no qual nada arrisca" ${ }^{21}$ e que, por ser proprietário de direito de uma parcela do globo terrestre, aparece no mercado "exigindo" parte da produção sem nada ter produzido. O trabalhador, então, transfere uma parcela do seu trabalho excedente ao proprietário da terra na forma de "renda do solo". Segundo Smith:

\footnotetext{
"Logo que a terra toda de um país se torna propriedade privada, querem os proprietários, como todas as demais pessoas, colher onde não semearam, e exigem renda fundiária até para os produtos naturais do solo ..." $\mathrm{O}$ trabalhador "tem de entregar ao dono da terra parte do que colheu ou produziu com o trabalho. Essa parte ou, o que dá no mesmo, seu preço constituí a renda fundiária" (SMITH, A. apud MARX, Vol. 1, 1980, p. 60 , grifos do autor)
}

Para Marx, Smith representa um considerável avanço em relação aos fisiocratas, quando reconhece o mais-valor como apropriação do sobretrabalho, tanto na indústria quanto na agricultura, ainda que não a concebesse como categoria específica.

Já no início do século XIX, com o desenvolvimento da grande indústria, outro importante expoente da Economia Política clássica ganha notoriedade: trata-se do inglês David Ricardo (1772-1823). Com ele surge uma teoria integrada do valor, do lucro e da renda. Ricardo se debruça com grande rigor sobre as obras de seus antecessores, sobretudo Adam Smith, e revoluciona o modo como até então se explicava a origem do valor. Ricardo defende a ideia

\footnotetext{
${ }^{20}$ SMITH, A. apud MARX, Vol.1, 1980, p. 57

${ }^{21}$ MARX, [1894] 2017, p. 833
} 
de que a origem e o fundamento do valor na produção capitalista são o tempo de trabalho. A ideia de que o tempo de trabalho determina o valor das mercadorias, deve ser aplicada não apenas ao trabalho investido na produção de mercadorias, mas igualmente naquele já contido previamente nas matérias-primas e nas máquinas e equipamentos (trabalho morto). Segundo Marx, Ricardo explica em sua obra que:

\begin{abstract}
"a proposição de ser o valor da mercadoria determinado pelo tempo de trabalho tanto se estende ao trabalho que se aplicou de imediato à mercadoria no último processo de trabalho, quanto ao tempo de trabalho contido na matéria. prima e nos meios de trabalho necessários à produção da mercadoria" (MARX, Vol. 2, 1980, p. 605)
\end{abstract}

O tempo de trabalho e o mais-valor passam a ser vistos como a gênese de toda acumulação capitalista. Como diz Marx, com isso ele distingue e aponta a contradição entre o funcionamento real e o funcionamento aparente do sistema. Ao contrário de Smith, para Ricardo não existe um equivalente invariável de valor pois todos os elementos que compõem o valor possuem quantidades variáveis de trabalho. O preço de mercado das mercadorias, segundo Ricardo, não é determinado pela lei da oferta e da procura como afirmava Smith, mas pelos preços de produção.

Em seus estudos sobre a renda na terra, Ricardo nega a existência de uma renda absoluta ${ }^{22}$. Por outro lado, revoluciona o modo como se discutia a questão da renda na terra ao atentar para um outro tipo de renda (para Ricardo, a de único tipo que se pode existir), a chamada renda diferencial, ou seja, "a diferença de magnitude da renda - a renda maior ou menor, decorrente da fertilidade diversa dos tipos de terra. Dada igual fertilidade, a renda diferencial só pode originar-se da magnitude diversa do capital aplicado" ${ }^{23}$. Em outras palavras, o autor concebe a renda diferencial de acordo com a fertilidade, onde se gera maior produtividade com a aplicação da mesma quantidade de trabalho (I) e como a diferença de produtividade obtida pela aplicação sucessiva de capital numa mesma terra (II). Com Ricardo encerra-se um período da Economia Política, que representa a "fase heroica" do pensamento burguês. Superar suas ideias implicaria, segundo o próprio Marx, ultrapassar a concepção burguesa de mundo. Tomemos agora o pensamento mais acabado de Marx sobre a origem do valor e sua relação com a formação dos preços da terra.

Já no capítulo primeiro d'O Capital, onde se toma a forma-mercadoria, Marx desvenda os fatores que a constituem, a saber, sua substância e sua grandeza. A essência e aparência da

\footnotetext{
${ }^{22}$ Ibid., p. 674

${ }^{23}$ Ibid., 671, grifos do autor
} 
mercadoria é constituída dialeticamente pelo seu valor de uso (substância) e seu valor (grandeza; expressado pelo valor de troca). Já de início, é importante esclarecer a ideia de que, para Marx, o valor é, antes de tudo, uma categoria social ${ }^{24}$. O valor de uso de uma mercadoria diz respeito à sua utilidade, ou seja, em como uma dada mercadoria satisfaz a necessidade humana e serve à sua conveniência através de suas propriedades. Ela "não existe sem um corpo. Por isso, o próprio corpo da mercadoria é um valor de uso ou um bem" ${ }^{25}$. A categoria valor é o ponto de apoio fundamental da relação capital-trabalho. É uma forma de mediação social generalizada no capitalismo determinada "pelo quantum de trabalho materializado em seu valor de uso, pelo tempo de trabalho socialmente necessário"26 à produção de uma mercadoria. Segundo Duayer e Araújo (2015): “O valor é a forma específica que a riqueza assume no capitalismo e, simultaneamente, uma forma de mediação social singular" ${ }^{\prime 27}$. O valor de troca aparece, então, como a forma de manifestação do valor, uma "relação quantitativa, a proporção na qual valores de uso de um tipo são trocados por valores de uso de outro tipo" 28 , a expressão de algo igual em mercadorias diferentes.

No momento crítico do capitalismo contemporâneo, Pereira (2017) ressalta a importância da historicidade do valor e reitera, a partir de Marx, que a sua objetividade "não é algo natural ou a-histórico. (...) A objetividade do valor é um fato social próprio das relações capitalistas de produção, sendo reposto na circulação por meio das relações de troca que estruturam a emergência do valor como trabalho abstrato"29

A categoria trabalho na obra de Marx é central na formação do valor. Um valor de uso ou um bem só possui valor porque há, objetivado nele, trabalho humano. E a grandeza desse valor é medida pela "quantidade de substância formadora de valor, isto é, da quantidade de trabalho nele contida" ${ }^{30}$. Porém, surge da própria forma-mercadoria, um caráter enigmático dos produtos do trabalho, onde estes são abstraídos e passam a ter vida própria no ato da troca e "as relações entre os produtores, nas quais se efetivam [as] determinações sociais de

\footnotetext{
${ }^{24}$ Em sua obra intitulada "Introdução ao Estudo do Método de Marx", José Paulo Netto, recorrendo à obra de Marx, diz que "as categorias "exprimem formas de modo de ser, determinações de existência, frequentemente aspectos isolados de [uma] sociedade determinada' (...) Por isso mesmo, tanto real quanto teoricamente, as categorias são históricas e transitórias: as categorias próprias da sociedade burguesa só tem validez plena no seu marco" (NETTO, 2011, p. 46, grifos do autor)

${ }^{25}$ MARX, [1867] 2013, p. 114

${ }^{26}$ Ibid., 263-264

${ }^{27}$ DUAYER e ARAÚJO, 2015, p. 23

${ }^{28}$ MARX, [1867] 2013, p. 114-115

${ }^{29}$ PEREIRA, 2017, p. 181

${ }^{30}$ MARX, [1867] 2013, p. 116
} 
seu trabalho, assumem a forma de uma relação social entre os produtos do trabalho" 31 . Marx prossegue analisando o caráter misterioso forma-mercadoria que, segundo ele:

\begin{abstract}
consiste, portanto, simplesmente no fato de que ela reflete aos homens os caracteres sociais de seu próprio trabalho como caracteres objetivos dos próprios produtos do trabalho, como propriedades sociais que são naturais a essas coisas e, por isso, reflete também a relação social dos produtores com o trabalho total como uma relação social entre os objetos, existente à margem dos produtores. É por meio desse quiproquó que os produtos do trabalho se tornam mercadorias, coisas sensíveissuprassensíveis ou sociais. (MARX, [1867] 2013, p. 147, grifos nossos)
\end{abstract}

Em outras palavras, surge um tipo de relação social entre os objetos do trabalho, independente da vontade dos produtores. Essa relação objetivada na forma-mercadoria, "é apenas uma relação social determinada entre os próprios homens que aqui assume, para eles, a forma fantasmagórica de uma relação entre coisas"32. A essa relação entre "coisas", Marx chama de fetichismo da mercadoria "que se cola aos produtos do trabalho tão logo eles são produzidos" $" 33$.

É necessário discorrer acerca dessas categorias centrais do pensamento marxiano pois o objeto central de análise nesta etapa, a terra - um bem natural não produzido, sem trabalho objetivado para sua formação, portanto não dotado de valor -, será analisada à luz da produção do espaço urbano pela chave análise do imobiliário, ou seja, da produção da mercadoria edificação constituída de valor que está a ela imbricada, tornando mais complexa a análise e a distinção da natureza dos ganhos que atuam na formação do preço dessa mercadoria, a saber, o lucro (na produção imediata da construção), a renda (advinda da captura de um mais-valor global a partir da propriedade) e o juro (através do adiantamento de capital para financiamento da compra do terreno, da produção e do consumo). Pereira (2017), ao analisar a relação dialética entre valor e preço, a partir de Marx, reforça essa ideia quando diz que o "valor não é preço, mas contraditoriamente aquele se expressa por meio deste" ${ }^{34}$. Em trabalho anterior, quando foca na propriedade imobiliária enquanto mercadoria especial e o descolamento entre o preço de produção do produto imobiliário e seu valor de venda, o autor reforça que:

"no mercado imobiliário, a propriedade da terra e a do edifício se sobrepõem como privatização de espaços enquanto propriedades imobiliárias, imbricando-se como mercadorias imóveis e equivalentes através dos preços de mercado. Embora sejam, do ponto de vista do valor,

\footnotetext{
${ }^{31}$ Ibid., p. 147

${ }^{32}$ Ibid., p. 147

${ }^{33}$ Ibid., p. 148

${ }^{34}$ PEREIRA, 2017, p. 177
} 
mercadorias absolutamente desiguais, encontram no valor representado no mercado a regulação de seus preços. $\mathrm{O}$ preço, medida e representação monetária do valor, parece representar a si mesmo. A existência do representante (preço) permite pressupor a existência do representado (valor)" (PEREIRA, 1988, pp. 8-9)

Como dito anteriormente, a moderna propriedade da terra passa a ser mobilizada como uma mercadoria constituída de preço. Como se dá a formação desse preço é o que buscaremos discorrer a seguir partindo de estudos acerca da renda auferida na terra.

É preciso avaliar que Marx, mesmo de forma incompleta, construiu sua teoria sobre a propriedade da terra e seus diferentes tipos de renda a partir da produção agrícola. No Livro III d'O Capital ele expõe sua tese sobre o tema por 11 longos capítulos. Em apenas um deles ele se ateve à questão da renda na construção, que é o que nos interessa aqui. Porém, seja na agricultura, na mineração ou na construção, o agente proprietário da terra é central para compreensão da renda. Harvey (2013), de maneira sintética, diz que a renda é "simplesmente um pagamento feito aos proprietários pelo direito de usar a terra e seus pertences" 35 . Em outras palavras, o proprietário da terra é a figura que possui um título por direito sobre uma parcela do globo terrestre e, como proprietário da mesma e de todas as riquezas ali presentes, extrai um sobrelucro, sob a forma de renda, do capital que usufrui daquele espaço. No contexto da produção imobiliária, onde a propriedade da terra e a construção se sobrepõem, essa renda se dá a partir da disputa da repartição do valor excedente frente ao capitalista construtor.

Segundo Harvey, o pagamento desse sobrelucro feito aos proprietários não seria possível "sem a troca geral de mercadorias, a plena monetização da economia e todas as armadilhas legais e jurídicas da propriedade privada na terra" ${ }^{36}$. Contudo, esse aparato legal que garante o direito à propriedade da terra e o pagamento pelo seu uso, não tem relevância sem haja a exploração de mais-valor do trabalho na terra. O setor da construção carrega, como composição da extração do mais-valor, o juro, o lucro e a renda. A parcela da renda então é o extraordinário, ou seja, aquilo que ultrapassa a garantia do lucro. Resgatando o que Marx escrevera no capítulo d'A Fórmula Trinitária acerca da formação dos rendimentos das três classes, a saber, o lucro do capitalista, a renda do proprietário da terra e o salário do trabalhador, temos que

\footnotetext{
${ }^{35}$ HARVEY, 2013, p. 428

${ }^{36}$ Ibid., 2013, p. 428
} 
assim como o capitalista ativo extrai do trabalhador o mais-trabalho e, com isso, sob a forma de lucro, o mais-valor e o mais-produto, também o proprietário fundiário extrai do capitalista uma parte desse mais-valor, ou mais-produto, sob a forma de renda fundiária. Para o capitalista, o capital é uma perpétua máquina de sugar mais-trabalho; o solo, um ímã inesgotável que atrai para o proprietário fundiário uma parte do mais-valor sugada pelo capital; e, por último, o trabalho é a condição que sempre se renova e o meio para obter, sob a forma de salário, uma parcela do valor produzido pelo trabalhador e, por conseguinte, uma parte do produto social proporcional a essa parte do valor, os meios de subsistência necessários. Então, além do lucro (lucros empresariais mais juros) esse mais-valor compreende também a renda ou, em suma, todo o mais-valor indiviso. Aqui, pelo contrário, como fonte de rendimento, tal expressão só se relaciona com a parte que recai sobre o capitalista. (MARX, [1894] 2017, pp. 883-886)

Em resumo, é a partir do trabalho vivo que o proprietário de terras aufere sua remuneração, ou seja, sua parte na distribuição do mais-valor global na forma de renda. Ele o faz diretamente ou por intermédio de outrem. Lefebvre aponta que os elementos supracitados, a saber, o lucro, a renda e o salário, "são representados como separados, e sua separação tem um sentido objetivo, pois cada grupo parece receber uma parte determinada do 'rendimento' global. Há, portanto, uma aparência alienada das relações sociais. É a ilusão da separação numa unidade, a da dominação do poder econômico e político da burguesia"37

O pagamento de uma renda ao proprietário pelo uso da terra é uma relação social. Portanto, não é a terra, em si, que gera renda, mas o fato de no capitalismo existir uma forma jurídica que garante o monopólio de porções do globo terrestre, transformando-a em propriedade privada. Assegurada por um conjunto de leis que a garante como tal, ela passa a ser comercializada, arrendada ou vendida como uma mercadoria.

A propriedade privada da terra não é uma invenção do modo de produção capitalista. Ela foi pressuposta, incorporada e adequada de maneira a engendrar as condições gerais de acumulação deste modo de produção. Em cada época da história, nos diversos tipos de sociedade, "a propriedade privada se desenvolveu de um modo diferente e sob um conjunto de relações sociais inteiramente diferentes" ${ }^{38}$. A medida que o capitalismo se desenvolvia, as antigas relações econômicas da propriedade da terra foram dissolvidas e foi se aprimorando o que hoje se entende como a moderna propriedade da terra. Harvey, citando Marx, escreve que a principal característica da moderna propriedade da terra "é a dissolução completa da conexão entre a posse da terra e a terra, a tal ponto que o proprietário desta

\footnotetext{
${ }^{37}$ LEFEBVRE, [1972] 2008, p. 51, grifo nosso

${ }^{38}$ HARVEY, 2013, p. 442
} 
última, em troca de um pagamento monetário direto, confere todos os direitos à terra como instrumento e condição da produção sobre o capital" ${ }^{39}$. A terra então passa a ser regida pelas leis de mercado, tornando-se um "bem comercializável, dependente do valor de troca e da especulação, não do uso e do valor de uso"40.

$\mathrm{Na}$ atualidade, com a hegemonia financeira, foram criados e aprimorados uma série de dispositivos legais para tornar mais aceleradas as transações que envolvem a propriedade da terra. Seguindo essa mesma linha, no Brasil, há muito vem se desenvolvendo uma série de marcos regulatórios que dão sustentabilidade e segurança a essas transações como a criação dos Fundos de Investimento Imobiliário (FIIs) e dos Créditos de Recebíveis Imobiliários (CRIs), mas também das leis do Patrimônio de Afetação, a Alienação Fiduciária o Valor do Incontroverso, instrumentos estes abordados mais adiante.

Tanto nas obras de Marx como na de Lefebvre, pode-se notar como os autores remontam cuidadosamente como determinadas condições socio-históricas desenvolveram o que se chama de moderna propriedade da terra. Em seus escritos, essa quebra de paradigma se dá com a transição de um antigo modo de produção específico para um novo. Em suma, eles descrevem o desenvolvimento do capitalismo a partir de seu modo de produção antecessor: o feudalismo. Nada mais natural, uma vez que ambos pensadores elaboram suas ideias a partir do contexto no qual estão inseridos, ou seja, os países de economias capitalistas avançadas europeus. Porém, pode-se afirmar com segurança que a história dos países latinoamericanos, e particularmente o caso do Brasil, esta transição se dá de uma forma particular, uma vez que estes países não passaram por este tipo de transição de base feudal. Harvey (2013) aponta que nestes países onde propriedade fundiária não era uma precondição, o capital engendra as condições necessárias para a formação da propriedade privada da terra. Para o autor,

Quando o capital encontra situações em que a propriedade privada da terra não existe, ela deve dar passos ativos para cria-la e desse modo garantir a produção do trabalho assalariado. E a necessidade de negar o acesso do trabalhador à terra como meio de produção não diminui de modo algum com o avanço do capitalismo. Na verdade, isso continua sendo uma necessidade permanente para que a reprodução da relação de classe entre o capital e o trabalho seja assegurada (HARVEY, 2013, p.462)

\footnotetext{
${ }^{39}$ Ibid., p. 442

${ }^{40}$ LEFEBVRE, [1972] 1999, p. 161
} 
Não é o intuito remontar aqui como se desenvolvera a economia colonial de base escravocrata nos países latino-americanos até o final do século XIX, tampouco adentrar nos pormenores da correlação de forças que se colocara entre os interesses das diferentes frações dominantes no período que antecedeu tal fato. O objetivo é apenas sublinhar o ponto de inflexão em que a terra se transforma e a centralidade que passa a ter com a instituição da moderna propriedade de base capitalista, bem como evidenciar como tal fato se desdobra no urbano. Abordaremos o caso brasileiro.

Fruto do aperfeiçoamento de um projeto que tramitava desde 1843 acerca da divisão de terras e colonização, a Lei de Terras de 1850 "é um marco no processo de mercantilização da terra no Brasil ${ }^{41}$. Após a interrupção da concessão de sesmarias com a Constituição de 1824, como aponta Smith (1990), "a resolução da questão fundiária, que impunha a iniciativa do Estado na tarefa de legitimar a propriedade privada e a discriminação das terras públicas ou estatais, permanece na mesma situação que a questão do tráfico [de escravos]" ${ }^{\prime 2}$ que havia tido sua interdição formal em 1831, mas não extinta de fato.

Neste imbróglio, muitas foram as tentativas de regulamentar a questão da propriedade fundiária no país, mas sempre esbarravam em interesses das frações da classe dominante agrária da época. No interim deste processo, até a promulgação da lei de 1950, iniciou-se um "amplo processo de apossamento de terras, que caracterizará, no país, a formação do latifúndio, na sua forma mais acabada"43.

Dentre os motivos mais urgentes para a regulamentação de uma lei que dispusesse sobre a propriedade da terra era a chegada cada vez mais maciça de trabalhadores livres imigrados da Europa e a inevitável abolição do trabalho escravo que se daria apenas em 1888, mas que já se avistava num horizonte próximo, sobretudo com a promulgação da lei que extinguia o tráfico de escravos - a Lei Eusébio de Queiroz, sob forte pressão da Inglaterra. Smith cita em sua obra o que seria um anteprojeto bastante esclarecedor, a respeito da promulgação de uma lei que salvaguardasse os interesses dos fazendeiros e senhores de escravos:

\footnotetext{
"um dos benefícios da providência que a Seção tem a honra de propor a Vossa Majestade Imperial é tornar mais custosa a aquisição de terras ... Como a profusão em datas de terras tem, mais que outras cousas, contribuído para a dificuldade que hoje se sente de obter trabalhadores livres é seu parecer que d'ora em diante sejam as terras vendidas sem
}

\footnotetext{
${ }^{41}$ FIX, 2011, p. 57

${ }^{42}$ SMITH, 1990, p. 303-304

${ }^{43}$ Ibid., p. 304
} 
exceção alguma. Aumentando-se, assim, o valor das terras e dificultando-se, consequentemente, a sua aquisição, é de esperar que o imigrado pobre alugue o seu trabalho efetivamente por algum tempo, antes de obter meios de se fazer proprietário" (SMITH, 1990, p. 306, grifos nossos)

A Lei de Terras formalizou uma legislação territorial que garantia a negociabilidade da terra. Seu principal ponto afirmava que toda terra devoluta não poderia ser adquirida por outro título que não fosse através de sua compra e a penalização de quem se delas se apossassem. Smith elenca outros pontos importantes da lei, como a legitimação da propriedade das sesmarias em comisso; a legitimação das posses já ocupadas; obrigatoriedade do título de posse da terra através de um registro de terras; dentre outros ${ }^{44}$.

A aprovação de uma lei que transformava a terra num bem comercializável tem estreita relação com o trabalho cativo exercido no Brasil até então. Martins (1979) traz uma interessante tese, centrada na metamorfose da renda capitalizada e conexão com as transformações do trabalho. Segundo o autor, "a renda capitalizada era a principal forma de capital tanto sob o regime do trabalho escravo quanto sob o regime do trabalho livre." 45 .

Durante o período que predominava o trabalho escravo no Brasil, a terra era destituída de preço. "A ocupação da terra obedecia a dois caminhos distintos: de um lado o pequeno lavrador que ocupava terras presumivelmente devolutas; de outro, o grande fazendeiro que, por via legal, obtinha cartas de sesmarias, mesmo em áreas onde já existiam posseiros" 46 .

Nesse sentido, eram os trabalhadores cativos que possuía valor de troca no mercado. $\mathrm{O}$ fazendeiro imobilizava seu capital na pessoa do escravo, como renda capitalizada, ou seja, um "tributo antecipado ao traficante de negros com base numa probabilidade de ganho futuro. $\mathrm{O}$ fazendeiro comprava a capacidade do escravo criar riqueza" ${ }^{\star 47}$. Em negociações de empréstimos entre fazendeiros e instituições bancárias, o escravo - e não a terra - servia como garantia no caso do não pagamento. Martins sintetiza essa inflexão da metamorfose da renda capitalizada ao afirmar que

\footnotetext{
"A renda capitalizada no escravo transformava-se em renda territorial capitalizada: num regime de terras livres, o trabalho tinha que ser cativo; num regime de trabalho livre, a terra tinha que ser cativa. No Brasil, a renda territorial capitalizada não é essencialmente uma transfigurada herança feudal. Ela é engendrada no bojo da crise do trabalho escravo, como meio para garantir a sujeição do trabalho ao capital,
}

\footnotetext{
${ }^{44}$ SMITH, 1990, p. 323-325

${ }^{45}$ MARTINS, 1979 , p. 23

46 Ibid., p. 24

${ }^{47}$ Ibid., p. 26
} 
como substituto de expropriação territorial do trabalhador e substituto da acumulação primitiva na produção da força de trabalho. A renda territorial surge da metamorfose da renda capitalizada na pessoa do escravo; surge, portanto, como forma de capital tributária do comércio, como aquisição do direito de exploração da força de trabalho. A propriedade do escravo se transfigura em propriedade da terra como meio para extorquir trabalho e não para extorquir renda. A renda capitalizada não se constitui como instrumento de ócio, mas como instrumento de negócio. Engendra, portanto, um capitalista que personifica o capital produtivo subjugado pelo comércio, a produção cativa da circulação" (MARTINS, 1979, p. 32, grifo nosso)

É importante registar essa "virada" onde a transformação da terra em mercadoria passa a ser central nas relações sociais de produção no Brasil, com suas especificidades frente a um processo global. Outro ponto importante de ser comentado é que "a Lei de Terras não incidiu imediatamente nas áreas urbanas, mas sim por meio de uma série de medidas tomadas nas décadas seguintes" ${ }^{4}$. O urbano passa então a se constituir "como uma fronteira de valorização dos lucros e dos excedentes obtidos em outras atividades pelo capital agrário, comercial e, futuramente, industrial" 49 .

Já em 1870, com a crise da economia agrícola de base escravista e, pouco a pouco, com a afirmação de uma economia urbana organizada com base no trabalho livre, o Rio de Janeiro, por toda sua importância econômica e política como capital do país, desponta como a primeira grande cidade brasileira a possuir um mercado capitalista. Com isso, "expande-se a intervenção sobre a cidade, através da legislação urbana e dos investimentos urbanos realizados pelo Poder Público e pelas empresas privadas" $" 50$.

Através de uma minuciosa investigação histórica acerca do mercado urbano de terras que se estabelecia, Ribeiro (1997) destaca que, no Rio de Janeiro, entre os anos de 1870 e 1890, há um crescimento vertiginoso do número de novos logradouros na cidade, expressando uma franca expansão na malha urbana carioca. Além disso, as chácaras e fazendas nos arredores do centro histórico passam a ser vendidos em grandes lotes ao mesmo tempo que há uma explosão demográfica, quase dobrando a população da cidade no período. Segundo levantamento do autor, "O crescimento populacional foi amplamente superior à domiciliar, houve uma deterioração das condições habitacionais, o que pode ser verificado pelo aumento da densidade domiciliar" ${ }^{\text {51 }}$. Esse fenômeno pode ser explicado, por um somatório de fatores:

\footnotetext{
${ }^{48}$ FIX, 2011, p. 59

${ }^{49}$ Ibid., p. 60

${ }^{50}$ RIBEIRO, 1997, p. 165

${ }^{51}$ Ibid., p. 169
} 
o afluxo de uma população de trabalhadores livres - seja de imigrantes portugueses ou de homens negros libertos - que chegavam à capital em busca de trabalho, buscavam também um lugar para sua moradia. Isso foi a condição perfeita para que um grupo de pequenos proprietários rentistas construíssem uma série de moradias coletivas, também conhecidas como cortiços, nas localidades próximas ao centro histórico da cidade. Com isso, a mercadoria-terra e a moradia passam a ter seus preços elevados, pois a renda capitalizada tem na propriedade da terra urbana sua fonte de riqueza e antecipa a partir dela, suas projeções de rendas futuras. Por outro lado, o aumento das atividades comerciais nas áreas centrais resulta no encarecimento do preço da terra e dos aluguéis na região, viabilizando a expansão e consolidação de um mercado de terras de loteamentos periféricos. Assim, esse centro histórico "perde boa parte da população residente, produto do processo de especialização comercial desta parte da cidade, tornando elevados os preços fundiários e

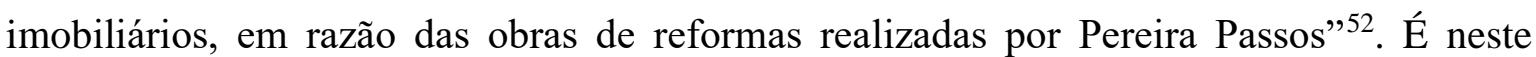
momento, enfim, que se constitui e um do mercado de terras urbanas na cidade e seu crescimento a partir de 1890.

A partir do exemplo do Rio de Janeiro, podemos agora iluminar uma característica central da terra enquanto propriedade privada. A chave de análise para a compreender a transição para sua forma mais acabada, ou seja, estritamente capitalista, está em compreender que a terra passa a ser tratada como um ativo financeiro (capital fictício).

Seguindo as pistas deixadas por Marx para apreender como se forma a renda nos terrenos para construção, podemos dizer de maneira geral que o proprietário da terra personifica um título de propriedade sobre uma parcela do globo terrestre e extrai dela seus ganhos monetários na forma de renda. No que diz respeito aos terrenos para construção, esta renda vem do predomínio do preço de monopólio ${ }^{53}$ de sua propriedade. Um dos pilares do modo de produção capitalista é manter uma massa de trabalhadores sem acesso à propriedade privada para, além de força-las a vender sua força de trabalho para um capitalista em troca de um salário que satisfaça o mínimo para sua reprodução, deve pagar um tributo na forma de aluguel em troca do direito de habitar a Terra já que este trabalhador necessita de moradia. Portanto, como aponta Marx, a necessidade cada vez maior de criar moradias, mas também

\footnotetext{
52 Ibid., p. 174

53 O preço de monopólio, segundo Marx, é um preço não regulado pelo seu preço de produção. “o preço determinado apenas pela ânsia de comprar e pela solvência dos compradores, independentemente do preço determinado pelo preço geral de produção, bem como pelo valor dos produtos" (MARX, [1894] 2017, p. 835)
} 
de capital fixo (edifícios industriais, ferrovias, etc.) que se incorporam à terra, aumentam necessariamente a renda imobiliária ${ }^{54}$. Neste caso, existe um duplo monopólio da terra: enquanto matéria (fins de extração e reprodução), mas também como espaço:

\footnotetext{
"Em ambos os sentidos a propriedade da terra exige seu tributo. A demanda de terrenos para construção eleva o valor do solo como espaço e fundamento, ao passo que, em virtude disso, aumenta simultaneamente a demanda de elementos do corpo terrestre que servem como materiais de construção" (MARX, [1894] 2017, p. 834)
}

Harvey avança nessa compreensão quando afirma que a aquisição de terras livremente comercializada assegura ao comprador o direito a uma renda que, por sua vez, pode ser vista meramente como juro sobre algum capital fictício. Nesse sentido,

\begin{abstract}
o dinheiro investido é, em todos os casos, capital que rende juros. A terra se torna uma forma de capital fictício e o mercado imobiliário funciona simplesmente como um ramo particular - embora com algumas características especiais - da circulação do capital que rende juros. Nessas condições, a terra é tratada como um simples bem financeiro que é comprado e vendido segundo a renda que ele produz. Como todas essas formas de capital fictício, o que é negociado é um direito sobre receitas futuras, o que significa um direito sobre os lucros futuros do uso da terra ou, mais diretamente, um direito sobre o trabalho futuro (HARVEY, 2013, pp.447-448, grifos nosso)
\end{abstract}

Conforme mencionado anteriormente, a terra é uma mercadoria especial por não possuir trabalho objetivado na sua composição, portanto a formação de seu preço não é estabelecida como em outras mercadorias que se constituem a partir do seu preço de produção. Nesse caso "o valor suposto é determinado pela pressuposição de um valor de troca estabelecido na relação com outras mercadorias através de um preço" ${ }^{55}$. O preço da terra então nada mais é que a expressão da capitalização da renda gerada pela mercadoria paga ao proprietário, cuja produção nela se localiza. No contexto da produção imobiliária, percebe-se um estranho descolamento entre o preço de produção da edificação e seu preço de mercado, como se neste setor os preços dos produtos não possuíssem qualquer fundamento, com expressivas variações ao longo do tempo. Esse estranhamento "resulta do encravamento do mercado de terras e do mercado de edifícios no mercado imobiliário, que funde, num único mercado, a propriedade da terra e a propriedade de edifícios, que se sintetizam como mercadorias através da valorização imobiliária" ${ }^{\circ 6}$. Portanto, ao preço de produção da edificação deve se

\footnotetext{
${ }^{54}$ A renda imobiliária advém da propriedade imobiliária, ou seja, do monopólio de privatização do espaço onde o seu uso por outrem dá ao seu proprietário o direito a ela [renda] pela propriedade.

55 PEREIRA, 1988, p. 9

${ }^{56}$ Ibid., p. 10
} 
incorporar a renda capitalizada da terra, que funciona sem um parâmetro claro uma vez que tem como base o alcance futuro de preços de monopólio. Com isso,

\begin{abstract}
A contradição qualitativa entre preço e valor torna-se central na particularização da reprodução do capital vinculado à produção imobiliária. À medida que a produção imobiliária capitalista passa a ser cada vez mais de mercado - visando, portanto, à lucratividade -, mais terá uma forma diferenciada de realização nas relações de competição intercapitalista. $\mathbf{O}$ preço de produção da construção não regulará o preço de mercado do imóvel, porque neste se sobrepõe o preço da terra como renda capitalizada (PEREIRA, 1988, p. 11, grifo nosso)
\end{abstract}

Como estratégia inexorável de expansão e acumulação capitalista, a partir das últimas décadas do século $\mathrm{XX}$, intensifica-se a produção do espaço visando a sobrevivência do sistema. Neste momento, o financeiro (dimensão econômica) e o imobiliário (dimensão espacial) se imbricam, formando uma parceria extremamente eficaz para seus devidos fins.

Lefebvre aponta que a partir da década de 1970, “da produção de coisas no espaço, passa-se à produção do espaço como tal" ${ }^{\Perp 57}$. O autor segue afirmando que no atual estágio do capitalismo, "o setor imobiliário se torna tardiamente, mas de maneira cada vez mais nítida, um setor subordinado ao grande capitalismo" 58 . O capitalismo se utiliza então do imobiliário para garantir sua reprodução ampliada subordinando o espaço ao mercado, se tornando um campo aberto para o investimento de capitais dos mais variados.

\footnotetext{
o espaço inteiro se torna o lugar da reprodução das relações de produção. As contradições do espaço não advêm de sua forma racional, mas do conteúdo prático e social, mais especificamente o conteúdo capitalista. Com efeito, o espaço da sociedade capitalista pretende-se racional, quando na prática é comercializado, despedaçado, vendido em parcelas (LEFEBVRE, [1972] 2008, pp. 53-57).
}

Para avançar na compreensão da relação dialética entre preço e valor na produção contemporânea do espaço, é necessário “compreender que o espaço como condição, meio e resultado dessa produção, tem na terra um elemento indissociável, um valor de uso que privatizado e comercializado, tem preço" ${ }^{\text {59 }}$. Em outras palavras, o espaço-mercadoria possui um valor de mercado, mas, por não ser fruto do trabalho humano, seu 'valor' é apenas uma expressão do preço. Neste sentido é possível afirmar que tal contradição se revela como uma relação fetichizada, nos termos de Marx.

\footnotetext{
${ }^{57}$ LEFEBVRE, [1972] 2008, pp.111-112

${ }^{58}$ Id., [1972] 1999, p. 163

${ }^{59}$ PEREIRA, 2017, p. 186
} 
Essa relação fetichizada entre preço e valor dá a aparência de que estas categorias possuem significados idênticos. Na produção do espaço essa relação encontra no conceito de especulação a explicação para os processos de encarecimento do preço da terra. Tal conceito possui grande influência e é largamente utilizado nas bibliografias acadêmicas sobre o tema, sendo também fortemente apropriada pelo senso comum. Contudo, esse conceito funciona como uma espécie de cortina de fumaça que encobre dois processos distintos e complementares ao mesmo tempo que, na produção do espaço, são fundamentais para a compreensão da totalidade de como o espaço é produzido. Tais processos são a valorização e a capitalização. Ambos processos representam formas de garantir rendimentos através do espaço para o capitalista construtor e para o proprietário da terra, o que torna difícil sua distinção. A valorização do espaço ocorre, em linhas gerais, quando o trabalho socialmente necessário é incorporado efetivamente na produção do espaço através das construções ou melhoramentos, sejam através de novas edificações, obras de infraestrutura, etc. Neste caso, trata-se da produção imediata do espaço. Por sua vez, a capitalização se liga a um processo fictício de precificação da terra através da captura de valorização (mais-valor, portanto) futura de algumas áreas. Ela projeta os ganhos de uma renda futura no tempo presente, ou seja, o proprietário da terra eleva o seu preço considerando que futuramente sua propriedade será objeto de ganhos monetários bastante superiores ao que ela pode lhe render no hoje. A capitalização antecipa que uma valorização tende a ocorrer no futuro, realizando-se em maior ou menor dimensão. Atualmente, essa relação dialética fica mais sobressaltada com a participação dos ganhos rentistas e financeiros de naturezas diversas incidindo sobre a produção do espaço e a capitalização passa a ser requerida tendo como imperativo a insaciabilidade do capital financeiro.

Cabe aqui destacar, a partir dos conceitos de valorização e capitalização, a diferença fundamental que se impõe entre renda fundiária e renda imobiliária, bem como a origem da remuneração de seus respectivos proprietários. No caso da renda fundiária, "é a partir da própria existência da renda no interior do processo de produção que se forma o preço de monopólio, como um lucro extraordinário que paga a renda”. Já no caso da produção imobiliária, essa renda se forma a partir do preço de monopólio aumentado pela competição comercial, pelo desejo e pela capacidade de pagar dos compradores que gera a renda" ${ }^{~}$. Pode-se dizer que, em linhas gerais, a renda fundiária se vincula ao processo de valorização

\footnotetext{
${ }^{60}$ Ibid., 2017, p. 204
} 
e a renda imobiliária, ao processo de capitalização da terra. Portanto, quando há uma elevação no preço do produto imobiliário, há uma sobreposição entre esses dois tipos de renda, pois além dele "se originar do sobrelucro (mais-valia) intra-setorial, como renda fundiária, também se origina da distribuição da mais-valia global inter-setorial, como renda imobiliária. Esse constitui o movimento particular de valorização-capitalização através da produção imobiliária" ${ }^{\text {1 }}$. De forma conclusiva, Tone esclarece que a definição do preço da terra no imobiliário

se dá menos em decorrência do trabalho necessário à sua produção imediata e mais na disputa pela apropriação do produto imobiliário (propriedade). Essa disputa é decidida pela capacidade de pagamento no mercado imobiliário, em que o preço se constitui e oscila initerruptamente, conforme o desenvolvimento urbano e econômico em geral" (TONE, 2015, p. 28, grifo nosso)

É incontestável que parte da variação do preço deriva do processo de valorização do espaço através de melhorias urbanas. Contudo, essa explicação é insuficiente, pois reduz a forma de formação dos preços imobiliários aos aspectos físicos da construção e urbanização, ou seja, ao trabalho necessário à sua produção imediata que, em muitos casos - vale ressaltar podem deteriorar seus preços como, por exemplo, a abertura do elevado Paulo de Frontin, no Rio de Janeiro, que deteriorou o preço dos imóveis de seu entorno imediato . A formação do preço do produto imobiliário se dá então "na distribuição da mais-valia global, pela formação dos preços no mercado imobiliário em que a propriedade imobiliária, de um lado, e a capacidade de pagamento, de outro, são preponderantes"62. Ainda assim, não é tarefa fácil desvendar a forma como a terra é precificada, pois, como ressalta Pereira (2017),

\footnotetext{
no "imobiliário" a propriedade da terra é parte do produto, meio de produção e condição de acesso. Mas, também, porque o espaço produzido, como produto do trabalho, é a mercadoria que contém valor e a partir do qual uma parte da mais-valia que ela realiza expressa o preço da terra sob forma de renda capitalizada. A capitalização dessa renda (uma transfiguração da mais-valia do produto imobiliário) constitui o "valor" da terra. Revela-se aí uma (ir)racionalidade de produção imobiliária capitalista "porque contém, nela própria, uma parte da mercadoria produzida (o edifício, como a coisa construída) e, outra, que não é resultado de trabalho (terra). (PEREIRA, 2017, p. 192)
}

Na produção contemporânea do espaço, o fetiche se complexifica, obscurecendo essas relações pois, com a financeirização atual, torna-se mais árduo desvendar a forma como a mais-valia global é repartida entre os diferentes agentes envolvidos (bancos, agências

\footnotetext{
61 TONE, 2015, pp. 41-42
}

62 TONE, 2015, p. 29 
financeiras, gestoras de fundos de investimento), pois sua repartição é pulverizada em diversos lugares e jurisdições, na maioria das vezes, bem distante do local de extração dessa mais-valia. A compressão do tempo-espaço através do desenvolvimento tecnológico torna isso não apenas possível, como desejável e vantajoso. "No caso da produção imobiliária o processo de distribuição da mais-valia global é central pelo fato de a propriedade privada integrar o produto em questão"63. Nessa lógica,

os preços monopolistas (e a renda capitalizada) no imobiliário ganham ainda maior autonomia seguindo a lógica financeira, em que se considera a taxa de retorno pela capitalização de todo o montante de capital-dinheiro adiantado, independente de que este tenha sido investimento na produção, na compra da terra ou outra despesa. Dessa maneira o monopólio da propriedade da terra incide na elevação da renda da terra ao conformar um mecanismo de distribuição da mais-valia que eleva, mutuamente, a renda e o preço de monopólio (PEREIRA, 2017, p. 202)

A produção imobiliária, associada à financeirização na atualidade, tende a obscurecer a relação entre valorização e capitalização na produção do espaço e a tornar cada vez mais insana a oscilação de preços dos produtos imobiliários. O segredo para elucidação deste problema é a compreensão da relação entre preço e valor e como este último se torna uma categoria central para compreensão da totalidade dos processos que se recolocam no atual regime de acumulação capitalista, pois é a partir da combinação entre a exploração do trabalho e a espoliação imobiliária e financeira que se conforma a gênese da reprodução capitalista atual.

Na sequência, abordaremos as características da produção do mercado, mais especificamente a forma incorporação e como este tipo de forma de produção ganha força e se consolida no contexto do Rio de Janeiro, impactando a dinâmica de crescimento da cidade. Por outro lado, os estudos sobre as formas de produção do espaço urbano, tendo como referência a cidade do Rio de Janeiro, ajuda a iluminar um debate teórico acerca da reificação das análises fragmentadas de produção do espaço baseada no padrão de estruturação urbana dual "centro (ricos) x periferia (pobres)". Nossa proposta é a de superação deste modelo fragmentado e limitador de análise dos processos de produção do espaço para explicar a evolução urbana da cidade.

\footnotetext{
${ }^{63}$ Ibid., p. 27
} 


\subsection{Formas de produção do espaço e avanço da incorporação imobiliária: a superação do padrão centro $x$ periferia}

A indústria da construção civil apresenta, de uma maneira geral, uma série de particularidades que a diferencia de outros setores produtivos, como o longo período de produção e circulação, ou seja, da rotação do capital, a necessidade da terra para a produção e o consumo e a dependência de financiamentos devido a seu alto preço para ampliação de uma demanda solvável. No contexto latino-americano dependente uma face dessas particularidades torna-se especialmente patente, a saber, a coexistência das formas de produção mais "atrasadas" com formas mais "avançadas" do ponto de vista da acumulação capitalista sem que isso constitua na eliminação das formas menos desenvolvidas como acontece em outros ramos produtivos. Basta lembrar um dos símbolos da Revolução Industrial, os teares mecânicos da indústria têxtil inglesa no século XIX, que aboliram, num curto espaço de tempo, os teares manuais devido sua alta capacidade produtiva e que na atualidade se mostram profundamente obsoletos frente aos teares informatizados. Retomando o ponto principal, Jaramillo (1982) aponta que no setor da construção, simultaneamente com a incorporação, forma que "opera de acordo com as estritas leis de acumulação de capital, existem outras formas transitórias e retrógradas de produção de 'espaço construído', com natureza e dinâmica muito particulares" ${ }^{\prime}$. Essas diferentes formas de produção que conformam o mesmo processo de urbanização são, segundo o autor, a produção doméstica ${ }^{65}$, a produção por encomenda, a produção de mercado e a produção estatal que se entrelaçam e se combinam na "produção do espaço em sua totalidade"66.

Nos estudos urbanos em geral, é comum notar a associação quase instantânea do conceito "forma de produção" a aspectos formais do produto imobiliário. Da mesma maneira, também é comum observar a correlação intuitiva que se faz das diferentes formas de produção a determinados espaços urbanos como, por exemplo, a alegação de que a produção de mercado está no "centro (rico)" e a produção doméstica na "periferia (pobre)". Ou a associação de que favelas são inevitavelmente realizadas como produção doméstica. Essas visões tendem a reificar a produção do espaço, ressaltando aspectos da aparência (forma) em detrimento de seu conteúdo social. Na atualidade, a coexistência e entrelaçamento entre as formas de

\footnotetext{
64 JARAMILLO, 1982, p. 152

${ }^{65}$ Em muitos trabalhos acadêmicos é comum o uso do termo "autoconstrução". Manteremos aqui o conceito original trabalhado por Jaramillo (1982).

${ }^{66}$ RUFINO e PEREIRA, 2011, p. 07
} 
produção se complexificam e suas distinções se tornam mais intricadas, vide o avanço das relações capitalistas a partir da produção de mercado no interior das favelas do Rio de Janeiro com a produção de grandes condomínios incorporados por empresas de capital aberto ou não - mais sofisticadas do ponto de vista da acumulação capitalista. De maneira sintética, as formas de produção são, antes de tudo, uma relação social. Para Jaramillo (1982), "trata-se de sistemas que relacionam os homens entre si e estes com os meios de produção para produzir um bem ou uma série de bens" ${ }^{67}$ e que são definidas pela conformação entre os agentes envolvidos no controle da produção e na estrutura de reprodução.

Nesse sentido, seguindo os objetivos expostos para este trabalho, buscaremos compreender a forma mais avançada das relações capitalistas na produção do espaço: a produção de mercado sob os imperativos da incorporação imobiliária cuja estrutura de produção se caracteriza pela

relação capital-trabalho assalariado, cujo sentido geral é a acumulação de capital através da apropriação do mais-valor gerado pelos trabalhadores do setor (embora o mecanismo de renda do solo permita atrair o mais-valor gerado em outros setores). Os agentes que detém o controle econômico direto da produção, embora apresente distintas variações, tem 0 denominador comum de serem agentes capitalistas. O controle técnico, embora existam conformações que se desviem dessa regra, é normalmente exercido por agentes que também são capitalistas ou extensões do próprio capital. A produção é orientada para o mercado geral onde o produto circula sob a forma de mercadoria e os processos produtivos tendem a ser repetitivos e contínuos (JARAMILLO, 1982, p. 186)

Rufino (2012) chama atenção para a importância que produção de mercado passou a ter na atualidade ao ponto de corriqueiramente se utilizar o termo "produção imobiliária" para se referir a esta forma de produção mais avançada do ponto de vista das relações capitalistas. Nos termos da autora, "cumpre ressaltar, que embora essa utilização esteja consagrada, representa uma transposição inadequada, que confunde as duas noções, uma geral e ahistórica - a produção imobiliária - e, outra, particular e histórica - a produção para mercado"68.

Na produção de mercado, as empresas incorporadoras são consideradas um ponto nodal em todo processo da promoção de cada empreendimento, desde sua concepção, passando pela escolha do terreno, público-alvo, a produção propriamente dita e a circulação. Segundo Topalov (1974), o incorporador imobiliário é "um agente social que gerencia a circulação

\footnotetext{
67 JARAMILLO, 1982, p. 175

${ }^{68}$ RUFINO, 2012, p. 36
} 
de capital imobiliário e sua transformação em mercadoria habitação" ${ }^{69}$. De maneira mais ilustrativa, Ribeiro (1997) complementa o conceito anunciado por Topalov ao apontar que

"Ele [o incorporador] é o "chefe da orquestra", tendo como função coordenar o processo produtivo e assumir as responsabilidades pela comercialização. (...) $\mathrm{O}$ iniciador e organizador do processo de produção da moradia. (...) É o agente que, comprando o terreno e detendo o financiamento para a construção e comercialização, decide o processo de produção, no que diz respeito às características arquitetônicas, econômicofinanceiras e locacionais" (RIBEIRO, 1997, pp. 92-94)

A origem da figura do incorporador no Brasil está ligada à mudança no regime de propriedades condominiais instituídas a partir do decreto 5.481 de 1928 que dispõe sobre a alienação parcial dos edifícios com mais de cinco andares. Esse decreto possibilita o surgimento "de uma figura que articula o proprietário original do terreno, os futuros compradores dos imóveis, o construtor e, posteriormente, o financiador, na criação de um novo bem que envolve relações jurídicas de propriedade privada e de propriedade coletiva"70 . Contudo, a instituição jurídica da figura do incorporador enquanto atividade econômica só apareceu no ano de 1964 através da Lei nº 4.591, cujo Artigo 29 o define como

\begin{abstract}
"pessoa jurídica ou física, comerciante ou não, que embora não efetuando a construção, compromissa e efetiva a venda de frações ideais de terreno objetivando a vinculação de tais frações a unidades autônomas, em edificações a serem construídas ou em construção sob regime condominial, ou que meramente aceite propostas para efetivação de tais transações, coordenando e levando a termo a incorporação e responsabilizando-se, conforme o caso, pela entrega, a certo prazo, preço e determinadas condições, das obras concluídas"
\end{abstract}

No interior do processo de incorporação de um empreendimento, o agente incorporador se desdobra em diversas figuras a depender do estágio da promoção e do agente com quem interage. Ribeiro (1997) aponta essas conexões estabelecidas entre os diversos agentes envolvidos no processo de incorporação em seus estudos. Apoiando-se nestas conexões, buscaremos atualiza-los segundo as transformações ocorridas no setor na atualidade com o imbricamento do imobiliário com o capital financeiro.

Segundo o autor, frente ao proprietário do terreno, o incorporador assume a dupla função de capitalista comercial e proprietário de terra. No primeiro caso, ele imobiliza um capital de circulação na compra da propriedade imobiliária. No segundo caso, já como proprietário, ele busca capitalizar a renda a partir da transformação do uso. Nesta disputa, a renda imobiliária

\footnotetext{
69 "un agent social qui assure la gestion d'un capital immobilier de circulation dans sa phase de transformation em marchandise logement" TOPALOV, 1974, p. 15

${ }^{70}$ RIBEIRO, 1997, p. 264
} 
não é transferida totalmente para o proprietário original. Parte dela - já capitalizada - será auferida pelo agente incorporador e pelos investidores financeiros. Neste último caso, como rendimento financeiro.

Frente ao capitalista construtor, há também uma dupla relação entre os agentes. O incorporador contrata a empresa construtora que ficará à cargo do controle técnico da construção. Contudo, esse controle é condicionado às exigências e comandos do incorporador que assume uma postura ativa nesse processo, uma vez que fica sob sua responsabilidade o planejamento e gestão da construção. Essa dupla conexão entre esses agentes "tem como origem o fato de ele não se restringir a um papel passivo de revender ou alugar o terreno adquirido, mas de promoção do empreendimento, gerindo a produção e a comercialização"71.

Como dito anteriormente, uma das particularidades do setor imobiliário frente a outros setores produtivos, é a dependência de financiamento tanto para a produção, mas principalmente para o consumo devido ao alto preço da mercadoria habitação para garantir a solvabilidade da demanda. Nesse sentido, o incorporador estabelece uma relação enquanto capital comercial com o capital financiador enquanto credor. Segundo Ribeiro (1997), esse capital é representado tanto pelas agências bancárias/financeiras que provê empréstimos quanto o investidor imobiliário que garante uma boa parcela das unidades do empreendimento para extrair delas um aluguel.

Contudo, na atualidade, essa relação entre incorporadores e capital financeiro ganha novas características a partir do momento em que as grandes incorporadoras nacionais abrem seu capital na bolsa de valores a partir de meados da primeira década do século XXI. Como veremos mais detalhadamente no próximo subitem, esse capital não cumpre mais a função de mero credor da produção, mas passa a compor a própria estrutura acionária dessas empresas em situação de comando. Essa mudança de patamar do capital financeiro frente a produção imobiliária de mercado, altera decisivamente a dinâmica não apenas dessas empresas, mas da produção do espaço das metrópoles.

No caso brasileiro, o Estado tem papel historicamente importante no financiamento imobiliário. Segundo Ribeiro (1997), a criação do Sistema Financeiro da Habitação (SFH) em 1964, atendendo as reivindicações do setor, corresponderá ao momento de consolidação

\footnotetext{
${ }^{71}$ Ibid, , p. 100
} 
da incorporação imobiliária no Brasil. "O SFH passou a fornecer exclusiva e diretamente ao incorporador $80 \%$ do capital necessário à realização dos empreendimentos não apenas desobrigando-o a realizar maciços investimentos, mas tornando-o "chefe da orquestra" frente a outros agentes e aos compradores" ${ }^{\text {, }}$. Além disso, com o decorrer do tempo, o SFH foi se adequando às novas demandas do setor imobiliário sempre que alguma crise entravava a produção de novos empreendimentos. Como veremos mais adiante, no recente processo de expansão imobiliária iniciado em meados da década passada, o Programa Minha Casa Minha Vida (PMCMV) passa a cumprir esse papel.

O Rio de Janeiro foi pioneiro na instituição da forma incorporação no Brasil com a invenção do apartamento-zona sul "destinado às camadas médias de alto poder aquisitivo, introduzindo uma importante diferenciação nas condições habitacionais" "73 a partir da década de 1940, a partir do bairro de Copacabana. Como já mencionado, esta forma se torna a mais avançada do ponto de vista da acumulação capitalista e, embora não elimine as formas anteriores, marginaliza a produção realizada pelo pequeno capital imobiliário que atuava, sobretudo, por encomenda, nos termos de Jaramillo (1982).

Em meados da década de 1960 com a crescente expansão da incorporação na produção de um espaço privilegiado da cidade, acirram-se também as contradições espaciais na cidade do Rio de Janeiro. A expansão e consolidação dessa forma de produção, embora relevante, não representa a maior parcela do crescimento imobiliário da cidade. Segundo dados da Light (concessionária de distribuição e comercialização de energia elétrica do município do Rio de Janeiro) trazidos nos estudos de Ribeiro, cerca de 56\% das novas construções residenciais da cidade não eram legalizadas pelo governo municipal. Tal informação pode causar certo espanto quando se percebe que a expansão do número de propriedades imobiliárias promovida pela expansão da forma condomínio avança concomitantemente com a produção doméstica de moradias - precárias na maior parte dos casos. Todavia, quando se analisa a produção do espaço urbano em sua totalidade, nota-se que o processo real engendra uma unidade contraditória (dialética) onde “o chamado 'moderno' cresce e se alimenta da existência do "atrasado",74. Sintetizando nos termos de Trotsky, um processo desigual e combinado.

\footnotetext{
${ }^{72}$ Ibid., pp. 300-301

${ }^{73}$ Ibid., p. 263

74 OLIVEIRA, [1972] 2013, p. 33
} 
Este debate de cunho teórico acerca das coexistências das formas de produção do espaço nos instiga a lançar luz sobre uma outra questão com a qual se relaciona estreitamente, a saber, as análises fragmentadas de produção do espaço baseada no padrão de estruturação urbana dual "centro (ricos) x periferia (pobres)" que ganhou bastante visibilidade e se consolidou nos estudos urbanos na América Latina a partir da Teoria da Urbanização Dependente desenvolvida por Manuel Castells (1973) e que, no caso brasileiro, serviu para explicar o processo de segregação socioespacial engendrado a partir do vertiginoso crescimento urbano brasileiro no período industrial, sobretudo após 1940, quando um grande contingente populacional foi forçado a migrar do campo para a cidade (êxodo rural) a fim de vender sua força de trabalho. Sustenta-se aqui a ideia de que o estabelecimento de um padrão dual de estruturação urbana tende a reificar o processo de produção do espaço na cidade capitalista, bem como limitar a compreensão de totalidade espacial. Lefebvre ([1968] 2010) adverte que "todo sistema tende a aprisionar a reflexão, a fechar horizontes"75. De maneira complementar, Pereira (2017) reforça que "falar em produção do espaço, implica, simultaneamente, em superar a fragmentação (espacial) e a setorização (econômica e social)" "76 uma vez que

\begin{abstract}
os estudos sobre urbanização muitas vezes se reduziram ao visível da cidade e ao segmentado da urbanização. Por isso, se tende mais a fragmentar a análise da metrópole do que a compreender sua fragmentação porque releva aspectos parciais e de escala desconsiderando elementos gerais e totalizantes, que envolvem a simultaneidade e o imbricamento de diferentes aspectos numa estrutura" (PEREIRA, 2013, p.100)
\end{abstract}

A diferenciação socioespacial - constituída historicamente e que nas cidades latinoamericanas se tornam ainda mais flagrantes - é um processo inexorável da produção capitalista do espaço, como apontado por Rufino e Pereira (2011). Nesta lógica, as diferentes formas de produção operam simultaneamente na produção do mesmo espaço urbano, negando-se umas às outras ao mesmo tempo que se impulsionam num movimento dialético.

No caso do Rio de Janeiro, a Teoria da Urbanização Dependente caiu como uma luva para reforçar o conceito carioca de subúrbio já consolidado na cidade. Tanto a teoria como o conceito supõem "que toda a periferia da cidade subdesenvolvida é pobre e socialmente desprestigiada. A lógica do modelo e o conceito se explicam, são coerentes entre si, ou seja, o modelo fundamenta teoricamente o conceito e este é a demonstração da validade histórica

\footnotetext{
${ }^{75}$ LEFEBVRE, [1968] 2010, p. 9

76 PEREIRA, 2017, p. 186, grifo nosso
} 
e empírica do modelo."77. É, portanto, a partir da dessas duas premissas que os estudos urbanos têm reificado a evolução urbana da cidade do Rio de Janeiro reforçando a dualidade entre centro (ricos) x subúrbio (pobres).

Contudo, tendo em vista a forma particular com que a cidade do Rio de Janeiro se expandiu e desenvolveu ao longo do século XX, é possível colocar em xeque as alegações de que o Rio se enquadra nos limites deste padrão. Dois fatores tornam-se decisivos nesta argumentação: apesar dos inúmeros esforços, o Estado não conseguiu erradicar todas as favelas das áreas nobres da cidade. O Rio de Janeiro se desenvolveu ao longo do século XX conciliando (não sem conflitos) diferentes formas de produção e diferentes estratos sociais no mesmo espaço. A favela da Rocinha em São Conrado, o Vidigal no Leblon e o Cantagalo/Pavão-Pavãozinho entre Ipanema e Copacabana são alguns dos exemplos mais comuns. Além disso, como aponta Fernandes (2011), a constituição da Barra da Tijuca como frente de expansão imobiliária na cidade a partir da década de 1980, rompe com a coerência interna do padrão dual centro x periferia. Apesar de sua posição "periférica" na cidade, a Barra se consolidou enquanto "subúrbio residencial de alto status na periferia urbana do Rio de Janeiro"78, ainda que não carregue este atributo. Abreu (2008) prevera que "apesar de constituir um bairro periférico, a Barra da Tijuca está, entretanto, sendo ocupada por classes de alta renda, o que leva a crer que, em futuro, próximo, será parte integrante do núcleo metropolitano",79.

Dentro deste pensamento, é a classe social que define a posição do que é núcleo, periferia ou subúrbio. $\mathrm{O}$ não reconhecimento da posição periférica da Barra da Tijuca coloca em evidência os limites e uma certa obsessão em se interpretar a estrutura urbana do Rio de Janeiro através do dualístico padrão tradicional latino-americano" (FERNANDES, 2011, p. 90)

Baseando-se na experiência do Rio de Janeiro, pode-se dizer que as análises do urbano latino-americano calcadas no modelo centro x periferia limitam a compreensão de sua totalidade e escamoteiam as múltiplas camadas que conformam a produção do espaço, bem como sua diversidade de produtos imobiliários uma vez que "justapõe espaços ricos e pobres e interpreta a cidade como se fosse um mosaico, onde se incrustam o centro vertical e a autoconstrução periférica" ${ }^{\sharp 0}$.

\footnotetext{
${ }^{77}$ FERNANDES, 2011, p. 89

${ }^{78}$ Ibid., p. 89

${ }^{79}$ ABREU, 2008, p. 18

${ }^{80}$ PEREIRA, 2005.
} 
Na contemporaneidade os processos de produção dos espaços das metrópoles ganham novas características, exigindo grandes esforços interpretativos e a superação de conceitos que davam conta de explicar outra realidade urbana que não a atual, pois "não se trata mais de realidades territoriais estanques (como historicamente procurou-se mostrar por meio do modelo centro-periferia), mas de uma realidade dinâmica, onde a diferenciação pode se apresentar em espaços justapostos"81. Isso pode ser notado a partir da expansão das fronteiras de acumulação a partir do imobiliário vinculado ao capital financeiro para todo espaço das metrópoles, consolidando a produção de mercado através da forma-incorporação. Nesse sentido, o território suburbano do Rio de Janeiro e também em outras metrópoles brasileiras despontam como a manifestação mais acabada desse processo. No item seguinte demonstraremos como se dá o imbricamento entre o financeiro e o imobiliário no contexto brasileiro e como essa associação transformou decisivamente o urbano brasileiro e o carioca, em particular, no século XXI.

\subsection{Financeirização da produção do espaço na periferia do capitalismo: notas sobre o contexto brasileiro}

A produção do espaço adquire novas características à medida que as relações sociais capitalistas se desenvolvem e se sofisticam. Assim, torna-se necessário compreender essas transformações para avançar o conhecimento nos estudos urbanos a partir de chaves de análise que deem conta de desvelar os processos que emergem da atualidade e que, na perspectiva desta dissertação, aponta para a problemática urbana - que se intensifica a partir do seu imbricamento com as finanças mundializadas - como central na sociedade contemporânea.

No início da década de 1970, Henri Lefebvre apontava para uma hipótese ousada que, embora virtual, já anunciava uma marcha acelerada para o que o autor denomina como sociedade urbana, ou seja, "a sociedade que resulta da urbanização completa. Aquela que nasce da industrialização e a sucede" 82 . Embora ousada, Lefebvre sustenta sua tese ao longo de toda sua obra a partir de duas dimensões que se relacionam dialeticamente: a teórica e a da práxis. Por este ângulo, o autor ainda ressalta que

\footnotetext{
${ }^{81}$ RUFINO e PEREIRA, 2011, p. 10

${ }^{82}$ LEFEBVRE, [1970] 2008, pp. 15-16
} 
a expressão "sociedade urbana" responde a uma necessidade teórica. Não se trata simplesmente de uma apresentação literária ou pedagógica, nem de uma formalização do saber adquirido, mas de uma elaboração, de uma pesquisa, e mesmo de uma formação de conceitos. Um movimento do pensamento em direção a um certo concreto e talvez para o concreto se esboça e se precisa. Esse movimento, caso se confirme, conduzirá a uma prática, a prática urbana, apreendida ou re-apreendida. (LEFEBVRE, [1970] 2008, p. 18, grifos do autor).

Passados quase 50 anos da hipótese virtual aventada por Lefebvre, já se pode afirmar com alguma segurança que tal hipótese - tendo em vista o acirramento da problemática urbana na contemporaneidade - tornou-se, em certa medida, real. No caso brasileiro, este acirramento pode ser analisado pela perspectiva da emergência do imobiliário que passa a ser mobilizado sob o predomínio do capital fictício na produção dos espaços das metrópoles nos últimos anos. Nesse sentido, esse processo se manifesta de maneira mais intensa em todo o território metropolitano, diferenciando-se de outros momentos onde alguns espaços se tornavam privilegiados enquanto lócus da reprodução ampliada do capital a partir do imobiliário. Por sua vez, os espaços menos valorizados dessas metrópoles que, no caso do Rio de Janeiro, é conhecido como subúrbio, passam a ser mobilizados como novas fronteiras de acumulação, inflexionando uma característica histórica dessas áreas de ser o lugar de reprodução e rebaixamento da reprodução da força de trabalho, num período urbanoindustrial que Maricato (2015) denomina, no contexto latino-americano, como urbanização com baixos salários que tem como traço marcante uma urbanização de padrão extensivo, horizontal, precário do ponto de vista das infraestruturas e tendo a produção doméstica e a estatal - embora não prescindisse da produção por encomenda e de mercado - como formas de produção predominantes. No caso do Rio de Janeiro, este período é marcado pela intensa eclosão das favelas nesses espaços menos valorizados da metrópole.

Também a partir dos anos 1970, como apontado por Amaral (2012), vem ocorrendo grandes transformações na forma como o sistema capitalista funciona e se organiza no mundo, passando a ingressar numa nova fase, a saber, aquela onde o aspecto financeiro passa a ter grande relevância nas transformações da dinâmica do sistema. Percebe-se, portanto, um outro movimento próprio do desenvolvimento das relações capitalistas que tem como característica a crescente autonomização das finanças frente aos capitais produtivos, sobressaltando o fato de como a financeirização, enquanto fenômeno social que emerge desse processo, está nos diversos níveis da vida cotidiana. Como já apontado, a financeirização é aqui compreendida nos termos de Lapavitsas (2011) como uma 
transformação sistêmica do modo de acumulação capitalista conduzida pelas economias capitalistas avançadas. Em sua tese, Amaral (2012) traz dados empíricos que demonstram a potência desse fenômeno global como o fato de que entre 1980 e 2006, o crescimento da riqueza fictícia no mundo, baseado no estoque de ativos financeiros mundial, foi muito superior ao crescimento do PIB em todo mundo. Enquanto o PIB cresceu 314\% no período, a riqueza financeira aumentou $1292 \%$.

Chesnais (2005), assinala que o capital financeiro sempre teve um papel importante para o funcionamento do sistema capitalista, contudo seu papel estava muito mais condicionado à figura de credor, ou seja, ao empréstimo de um dinheiro que lhe será devolvido no tempo acrescido de juros. O que muda na atualidade é que esse capital sai de uma figura mais "passiva" e desloca-se para o quadro acionário das empresas onde aplica seu capital e, com isso, influenciando diretamente na organização e rumos das mesmas, ainda que se mantenha numa posição externa ao processo produtivo. De acordo com o autor, "o mundo contemporâneo apresenta uma configuração específica do capitalismo, na qual o capital portador de juros está localizado no centro das relações econômicas e sociais"83.

Nesse cenário, as instituições financeiras, fundos de investimentos, fundos de pensão e até mesmo as instituições bancárias passam a ter protagonismo na aplicação mais rentável dos capitais nelas investidos, sobretudo fortunas familiares e lucros auferidos no setor produtivo e que não foram reaplicados produtivamente, mas também de fundos de previdência privada de trabalhadores. A "nova cara" do capitalismo passa a ser qualificada não mais pelo arquétipo do capitalista enquanto indivíduo proprietário dos meios de produção tal como conhecido no período industrial, mas justamente pelo investidor anônimo que se associa a outros montantes de capital advindos de diversos lugares do planeta tendo como finalidade “'fazer' dinheiro sem sair da esfera financeira, sob a forma de juros de empréstimos, de dividendos e outros pagamentos recebidos a título de posse de ações e, enfim, de lucros nascidos de especulação bem-sucedida" ${ }^{"}$. Por se tratar de um comando externo ao processo de produção, esse capital tem como aspecto determinante uma obcecada "insaciabilidade", onde as maiores rentabilidades somada a uma rápida liquidez são imperativas. Acerca desse aspecto, Chesnais (2005) pontua que

a pressão "impessoal" dos "mercados", exercida sobre os grupos industriais pelo viés do nível comparado da taxa de juros sobre os títulos da dívida e

${ }^{83}$ CHESNAIS, 2005, p. 35

${ }^{84}$ Ibid., p. 35 
dos lucros industriais, se multiplica em formas de controle muito mais diretas, que beneficiam construções teóricas feitas sob medida. Impõem-se novas normas de rentabilidade, que geram pressões bastante acentuadas sobre os salários, tanto em termos de produtividade e de flexibilidade do trabalho, como de mudanças nas formas de determinação dos salários" (CHESNAIS, 2005, p.42).

Fazendo um resgate histórico a fim de contextualizar as transformações que caracterizam as especificidades atuais do sistema capitalista, pode-se dizer que esse processo é desencadeado com a crise no interior regime de acumulação fordista-keynesiano - os "anos dourados" do capitalismo -, marcado pela forte industrialização, consumo em massa, reconstrução das infraestruturas arruinadas (no caso europeu) e pelo Estado de bem-estar social nos países capitalistas centrais consolidados após a Segunda Guerra Mundial. A crise desse modelo já no início da década de 1970 devido à dificuldade cada vez maior de sustentação do crescimento econômico - foi determinada, segundo Amaral (2012), pelo inchaço do setor manufatureiro internacional combinado com a vertiginosa queda dos lucros das empresas dos setores da indústria e serviços. Além disso, a capacidade de manter em progresso a ampliação de mercados de consumo dava claros sinais de esgotamento. Esses fatores foram fundamentais para entravar a retomada de crescimento. Segundo Gorender (1997),

\begin{abstract}
as deficiências e insuficiências do fordismo salientaram-se, particularmente no quadro do primeiro choque do petróleo (1973) e da recessão cíclica de 1973-1975. Simultaneamente, acentuavam-se as dificuldades fiscais do intervencionismo estatal keynesiano e do Estado do Bem-Estar Social. A aceleração do processo inflacionário evidenciava os tropeços do regime fordista-keynesiano, no momento em que a acumulação de capital e o crescimento das forças produtivas tocavam os limites cíclicos da economia capitalista. (GORENDER, 1997, p. 314)
\end{abstract}

O que se vê a partir disso é a ascensão de ideias neoliberais que já vinham se mostrando potentes desde o final da década de 1960, abrindo caminho para uma reestruturação que buscava alternativas mais rentáveis de aplicação de capitais excedentes que não podiam ser reinvestidos de maneira lucrativa na produção. "O cenário que se desenhava no momento era, então, caracterizado por crescimento dos investimentos, elevação dos preços das ações e queda da lucratividade" 85 .

Em outra obra, Chesnais (1998) aponta que é a partir de 1986 - após um período preliminar de internacionalização financeira entre 1960 a 1979 e, posteriormente, com um ciclo de consolidação das finanças de mercado sem a intermediação bancária a partir de um processo de desregulamentação e liberalização financeira entre 1979 e 1985 - que as finanças se

\footnotetext{
${ }^{85}$ AMARAL, 2012, p. 74
} 
consolidam em todo mundo, incorporando mercados em desenvolvimento e generalizando a especulação. Na esteira desse processo, os Estados passam a atuar na consolidação das condições de implementação da mundialização financeira através do tripé desregulamentação-descompartimentalização-desintermediação, conforme apontado por Chesnais (2005). De maneira mais elucidativa, "A desregulamentação ou liberalização monetária e financeira, a descompartimentalização dos mercados financeiros nacionais e a desintermediação, a saber, a abertura das operações de empréstimos, antes reservadas aos bancos, a todo tipo de investidos institucional" $"$.

Alguns momentos no decorrer da década de 1970 foram bastante representativos de como esse processo marca também uma política de Estado dos países centrais e conduzida pelos Estados Unidos. A recessão da economia estadunidense levou, em 1971, à saída do país do acordo de Bretton Woods, encerrando o padrão de paridade dólar-ouro e marcando o início de um padrão com características puramente financeiras baseado na flutuação do dólar. Em 1974, através do então subsecretário do tesouro Paul Volcker, os Estados Unidos passam a praticar uma política conhecida como Dólar Forte, através da manutenção de altas taxas de juros e alta do câmbio. Já em 1979, há uma intensificação dessas políticas iniciadas poucos anos antes e que ficou conhecido como o "Golpe de 1979" ou "Choque de Juros" onde os Estados Unidos, por meio de elevação excessiva das taxas de juros "da noite para o dia", aceleraram as medidas de liberalização e desregulamentação de sua economia, bem como de uma política de aprofundamento do endividamento de países devedores e de si próprio. Como consequência desse choque, pode-se citar o desencadeamento da crise da dívida dos países subdesenvolvidos no início da década de 1980, que atingiu em cheio a economia dos países da América Latina. Segundo Amaral (2012) este momento tornou-se emblemático, pois é a partir dele que se configura um novo patamar de acumulação na periferia do sistema. Como assinala Fiori (1997),

\footnotetext{
Iniciou-se ali um vasto processo de desregulamentação monetária e financeira que permitiu o surgimento dos mercados de obrigações interconectados internacionalmente onde os governos passam a financiar os seus déficits colocando títulos da dívida pública nos mercados financeiros globais e transformando-se em reféns da "ditadura dos credores" (FIORI, 1997, p. 91)
}

Para Chesnais (2005), o poderoso crescimento das finanças contemporâneas, bem como a sua consolidação podem ser explicados pela coexistência de três fatores:

\footnotetext{
${ }^{86}$ CHESNAIS, 2005, p. 46
} 
A primeira concerne ao movimento de autonomia relativa da esfera financeira em relação à produção, mas sobretudo em face da capacidade de intervenção das autoridades monetárias. A segunda relaciona-se ao caráter fetiche, perfeitamente mistificador, dos "valores" criados pelos mercados financeiros. A terceira remete ao fato de que são os operadores que delimitam os contornos da mundialização financeira e decidem quais agentes econômicos, pertencentes a quais países e em quais tipos de transações, participarão. (CHESNAIS, 2005, p.45, grifos nossos).

Vale lembrar, contudo, que o debate sobre o capital portador de juros e o importante papel que as finanças possuem na economia não é um assunto novo. Engels chegou a esboçar um pequeno artigo sobre o tema intitulado A Bolsa, onde, no final do século XIX, já demonstrava indícios do eminente protagonismo financeiro no interior da própria produção capitalista. Segundo Pereira, "Engels ainda menciona uma transformação gradual da indústria em

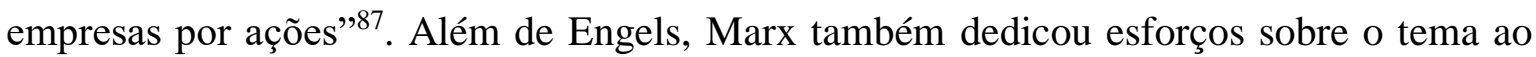
analisar criticamente essa exteriorização da relação capitalista sobre a forma de capital portador de juros no decorrer de toda a Seção V no volume terceiro d'O Capital. Para o autor, esse capital passa a assumir sua forma mais fetichizada, onde dinheiro aparentemente “cria" mais dinheiro (D-D'). De forma bastante elucidativa, o pensador alemão escreve que

a relação social é consumada como relação de uma coisa, o dinheiro, consigo mesma. Em vez da transformação real do dinheiro em capital, aqui se mostra apenas a sua forma vazia de conteúdo. Assim como na força de trabalho, o valor de uso do dinheiro transforma-se em fonte de criação de valor, de um valor maior que está contido nele mesmo. Como tal, o dinheiro é potencialmente um valor que se valoriza a si mesmo e que é emprestado, o que constitui a forma de venda para essa mercadoria peculiar. Assim, criar valor torna-se uma qualidade do dinheiro tanto quanto dar peras é uma qualidade da pereira (MARX, [1894] 2017, p.442).

A partir das ideias lançadas por Marx, pode-se compreender como este capital - representado na figura do crédito, ou seja, externo às relações capitalistas descritas - se situa numa posição de emprestador de uma quantia de dinheiro que lhe seria devolvido, no tempo, acrescido de juros. Conforme descrito por Chesnais (2005), na atualidade, o capital portador de juros funciona como uma propriedade patrimonial que tem na figura do proprietário-acionista detentor de títulos de empresas o seu principal representante. Por este ponto de vista, é nesse agente capitalista que se concentra "os meios de influir na repartição da renda em duas dimensões essenciais: a da distribuição da riqueza produzida entre salários, lucros e renda financeira, e a da repartição entre a parte atribuída ao investimento e a parte distribuída como dividendos e juros" ${ }^{\prime 88}$. Portanto,

\footnotetext{
${ }^{87}$ PEREIRA, 2017, p. 174

${ }^{88}$ CHESNAIS, 2005, p. 48
} 
os detentores das ações e de volumes importantes de títulos da dívida pública devem ser definidos como proprietários situados em posição de exterioridade à produção, e não como "credores". O regime de acumulação contemporâneo (...) foi caracterizado como "patrimonial". A palavra remete a relações econômicas e sociais das quais o termo 'credor' não dá conta. Um patrimônio designa uma propriedade mobiliária e imobiliária que foi acumulada e dirigida para o "rendimento" (CHESNAIS, 2005, pp.48-49, grifos nossos)

Com base no fragmento anterior exposto pelo autor francês, pode-se fazer uma primeira aproximação do tema com a produção do espaço que, a rigor, perpetua-se enquanto produção de propriedades imobiliárias, pois essa propriedade (patrimonial) no contexto contemporâneo "cria direito a rendas sob a forma de aluguéis, de rendas do solo. (...) $A$ finalidade dela não é nem o consumo nem a criação de riquezas que aumentem a capacidade de produção, mas o 'rendimento" ${ }^{\circ 9}$. O que se forma a partir disso é uma relação intricada entre os ganhos advindos do capital que, na atualidade assume também uma forma financeira e da renda de monopólio sobre uma parcela do globo terrestre, pois "é em torno da captura de parte da mais-valia, sob a forma de juro e de renda, que emerge uma nova coalizão das finanças mundializadas, que abarca o financeiro e a produção imobiliária" ${ }^{90}$. Uma outra aproximação com a produção do espaço pode ser feita a partir das ideias de Chesnais quando o autor aponta, como consequência do avanço das finanças, duas situações relevantes: a primeira diz respeito ao processo de centralização do capital como processo que resulta das fusões e aquisições de empresas estruturadas pelos investidores financeiros. A outra tem a ver com a maneira pela qual a finança conseguiu consolidar a 'exterioridade da produção' no coração das relações capitalistas atuais. O processo da reestruturação imobiliária despontado em meados da última década nas metrópoles brasileiras, expõe esses pontos elencados pelo autor de forma bastante clara. A abertura de capital das grandes incorporadoras nacionais foi um marco no avanço das relações capitalistas no setor imobiliário. O que se notou a partir desse momento, foi a aquisição de empresas médias e pequenas, de atuação local, para expansão territorial e diversificação dos produtos imobiliários das "grandes", impactando decisivamente a organização espacial do urbano. Este tema será abordado minuciosamente nos próximos capítulos.

Seguindo desses apontamentos gerais acerca da financeirização enquanto fenômeno social que desenvolveu as relações capitalistas globalmente, torna-se necessário compreender a

\footnotetext{
${ }^{89}$ Ibid., p. 50

${ }^{90}$ PEREIRA, 2017, p. 185
} 
inserção da economia dependente brasileira no interior desse sistema que, por sua vez, engendra "um novo fator determinante e condicionador da capacidade de crescer (e se desenvolver) das economias periféricas" ${ }^{91}$. A partir das pressões externas, o Estado brasileiro se torna o principal agente condutor desse processo, transformando sua economia numa plataforma de valorização financeira internacional que tem no neoliberalismo, seu alicerce de sustentação ideológica e política. Segundo Amaral (2012), as relações econômicas internacionais se intensificam na atualidade "pautadas pela ação imperialista ${ }^{92}$ empreendida por determinadas estruturas capitalistas através da intensificação do movimento de capitais, sustentando a necessidade de que estas estruturas definam o plano mundial como sua esfera de atuação" $"$.

Para compreender o papel que o Brasil tem hoje frente ao capitalismo financeiro, Paulani (2012), faz uma retrospectiva histórica do processo de inserção da economia brasileira no movimento de acumulação capitalista em nível mundial. A autora elenca cinco fases ao longo da história brasileira na qual a economia brasileira foi importante de diferentes formas dentro do sistema econômico mundial.

De forma sintética, o Brasil teve, nos seus primórdios, um importante papel como reserva patrimonial no período chamado de acumulação primitiva no capitalismo, fornecendo metais preciosos e matéria-prima (commodities) aos países centrais do capitalismo, sobretudo os da Europa. Passada essa fase e indo até o início do século XX, o Brasil desempenha um importante papel como "alavanca da acumulação" dos países do Centro, fornecendo bens primários de baixo valor agregado. Paulani (2012) assinala que, somadas, essas duas primeiras fases representam cerca de quatro séculos da história do Brasil.

$\mathrm{Na}$ terceira fase que se inicia a partir de 1930, o Brasil tem a possibilidade de comandar internamente seu processo de acumulação favorecido por uma conjuntura de crise econômica

\footnotetext{
91 AMARAL, 2012, p. 03

92 Tal como propõe Lenin ao dizer que "o imperialismo é, pela sua essência econômica, o capitalismo monopolista. Isto já determina o lugar do imperialismo na história, pois o monopólio, que nasce solo da livre concorrência e precisamente a partir dela, é a transição do capitalismo para uma ordem econômica e social superior" (LENIN, [1917] 2012, p. 165)". Contudo, na etapa atual do capitalismo o imperialismo tal como proposto por Lenin ganha novos contornos ainda que mantenha seu fundamento inicial. Além disso, é necessário pontuar que as ideias de Lenin são bastante generalistas e tem como objetivo a apreensão das bases que formam essa fase superior. Nesse sentido, é mister compreender como o imperialismo se manifesta de diferentes formas nos diferentes contextos.

93 Ibid., pp. 03-04
} 
de escala mundial em decorrência da sobreacumulação de produtos que atingiu os países do centro do capitalismo na crise de 1929. Segundo a autora,

\begin{abstract}
o capital do Centro do sistema vai encontrar na economia brasileira, nos anos 1950, o mercado que começava a escassear no mundo desenvolvido. O país torna-se assim objeto do deslocamento espacial do capital do Centro, fazendo com que o processo de acumulação "determinado desde dentro" fosse comandado, nos setores mais dinâmicos da economia, pelas necessidades e imperativos do capital de fora (PAULANI, 2012, p.90)
\end{abstract}

Já na quarta fase iniciada na década de 1970, num contexto de consolidação das finanças nas relações capitalistas em que se altera consideravelmente as características de acumulação em todo mundo, a autora aponta que é nesse contexto que "começa a se constituir aquilo que viria a ser chamado de 'financeirização', indicando um processo em que a acumulação se dá sob os imperativos e a lógica da valorização financeira"94. Segundo Paulani, esse novo regime de acumulação "vai encontrar no Brasil a demanda por empréstimos que faltava a um capital financeiro robusto e ávido por aplicações no contexto de uma crise de sobreacumulação irresolvida no Centro" 95 . É nesse contexto, como já mencionado anteriormente, que desenrola a crise da dívida dos países da América Latina, ocasionando um longo período durante a década de 1980 de estagnação da economia brasileira. Ela ainda defende a ideia de que nesta etapa, a economia brasileira "ingressou" nesse processo de financeirização de forma passiva, uma vez que

\begin{abstract}
A explosão do endividamento na economia brasileira e sua entrada na ciranda financeira foi algo determinado de fora para dentro, foi resultado das decisões políticas das economias centrais, em especial da economia norte-americana, que, diante da necessidade de reafirmar o dólar como dinheiro mundial, decretou a quadruplicação de suas taxas de juros internas, produzindo com isso um desmesurado salto nas despesas com juros que os ativos financeiros de emissão brasileira decorrentes dos empréstimos efetuados nos anos 1970 deveriam honrar (AMARAL, 2012, p. 117)
\end{abstract}

No início dos anos 1990, com a consolidação do processo de financeirização em todo mundo como periodizado por Chesnais (1998), a economia brasileira se transforma no que Paulani denomina como "plataforma internacional de valorização financeira" ${ }^{96}$. Nesse sentido, o Brasil passa a adotar "uma opção política conscientemente definida na agenda daqueles que assumiram a condução do país respaldados ideológica e politicamente pelos princípios neoliberais"97. Chama atenção o fato de que esse conjunto de ações foi

\footnotetext{
94 PAULANI, 2012, p. 91

95 Ibid., p. 91

96 Ibid., p. 91

97 AMARAL, 2012, p. 117
} 
a forma encontrada pelo país para escapar da armadilha constituída pelo binômio "crise da dívida-alta inflação", que marcou a fase anterior, foi a completa submissão de sua política econômica às exigências dos credores, em outras palavras a adoção do discurso e da prática neoliberais. O desdobramento desse processo vai colocar o país como uma permanente fonte de oferta de ganhos financeiros ao capital cigano que gira o mundo buscando as aplicações mais lucrativas (PAULANI, 2012, p.91)

No decorrer da mesma década, surfando no receituário neoliberal consolidado no mundo, o Estado brasileiro tomou as providências necessárias para o ingresso do país na era da financeirização. Foi a partir do então governo de Collor de Mello que tais medidas foram implementadas e ganharam força nos governos seguintes com Itamar Franco, Fernando Henrique Cardoso e Luiz Inácio Lula da Silva. Como característica das políticas austeras que se iniciaram no período, estão a "privatização de empresas estatais, redução das instituições do Estado, controle dos gastos públicos, emissão de títulos da dívida pública, desregulamentação do mercado financeiro nacional, prática de altas taxas de juros, início da privatização do sistema previdenciário e precarização nas relações de trabalho"98. Até o primeiro mandato de Lula, pode-se dizer que as estratégias adotadas no país foram as de acumulação de déficit, ou seja, de atração de capital estrangeiro para garantir as regras do Fundo Monetário Internacional (FMI) e a estabilidade monetária. Já a partir deste mesmo mandato presidencial, adota-se a estratégia de acumulação de reservas internacionais, com a atração de capitais estrangeiros e intensificação do lançamento de títulos da dívida pública, aumentando o endividamento interno e consolidando o Brasil enquanto plataforma de valorização com a transferência de excedentes a partir das finanças.

Mesmo que tenha se consolidado historicamente como uma força progressista no campo da esquerda, no governo Lula a política econômica não muda. “A liquidez é rigidamente controlada, os juros permanecem em patamares extremamente altos e os superávits primários elevam-se para além dos níveis exigidos pelo próprio FMI"99. Ademais, outras medidas como a reforma da previdência do funcionalismo público e a reformulação da lei de falências no sentido de priorizar os credores financeiros foram tomadas para aumentar o grau de confiança do país e completar o processo de inserção nos circuitos mundiais de acumulação financeira.

Diante de um cenário macroeconômico internacional favorável, o Brasil conseguiu reduzir as taxas de juros, estabilizar a inflação e o câmbio e diminuir o risco-país neste período,

\footnotetext{
98 TONE, 2010, p. 16 apud RUFINO, 2012, p. 49

${ }^{99}$ Ibid., p. 93
} 
ajudando assim a elevar o montante de crédito imobiliário transacionados pelas instituições financeiras.

Na atualidade, Paulani (2012) assevera que "a economia brasileira é hoje uma economia financeirizada, com um acelerado processo de centralização de capitais e completamente integrada ao capitalismo rentista dominante" ${ }^{100}$, concentrando no Estado a principal fonte de acumulação rentista, praticando uma das taxas de juros mais altas do mundo e comprometendo uma parte considerável do orçamento com o pagamento dos rentistas. Concluindo, pode-se dizer que a inserção da economia brasileira se insere na atualidade "no cenário mundial como emergente plataforma de valorização financeira, garantindo ganhos inigualáveis num mundo em que as taxas de juros reais são nulas ou negativas" ${ }^{101}$.

Todo esse cenário brasileiro acima descrito vem transformando também a produção do espaço no Brasil desde a década de 1990. Porém, é a partir de meados da primeira década do século XXI que esses processos se intensificam, tendo como principais agentes dessas transformações em curso as grandes incorporadoras e construtoras nacionais que se vinculam ao capital financeiro mundial a partir da abertura de capital na Bolsa. Esse movimento culminou numa acelerada expansão de novos empreendimentos imobiliários em várias cidades brasileiras - sobretudo nas metrópoles - para espaços menos valorizados, não raro precários, onde historicamente esse mercado não atuava, desencadeando um intenso processo de capitalização das propriedades imobiliárias, elevando freneticamente seus preços.

$\mathrm{Na}$ esteira desses processos onde as relações capitalistas de caráter financeiro passam a ser hegemônicas, há, "um reconhecimento, cada vez maior, de que os fenômenos atinentes às finanças não se limitariam às altas esferas de especulação internacional com moedas e papéis, possuindo também importantes ramificações na prática cotidiana das sociedades" ${ }^{102}$. Sanfelici (2013a) ainda ressalta também que os estudos sobre o impacto da financeirização na sociedade não podem ser simplificados e reduzidos a uma mera dominação das finanças sobre o setor produtivo, pois, sendo ela um fenômeno social e uma transformação sistêmica do próprio modo de acumulação, possui como característica a penetração em todas as relações da vida cotidiana, seja econômica ou social. Nessa lógica, "a urbanização pode,

\footnotetext{
${ }^{100}$ PAULANI, 2012, p. 97

${ }^{101}$ Ibid., p. 98

102 SANFELICI, 2013a, p. 28
} 
então, ser compreendida como um fenômeno que se encontra, crescentemente, sob influência do capital portador de juros" $" 103$.

Nesse duplo movimento que tem, de um lado, a emergência do imobiliário (dimensão socioespacial) e de outro, a hegemonia das finanças (dimensão socioeconômica) como centrais para as relações sociais capitalistas atuais, Lefebvre ressalta a importância do espaço para o sistema afirmando que

\begin{abstract}
o capitalismo se estendeu subordinando a si o que lhe preexistia: agricultura, solo e subsolo, domínio edificado e realidades urbanas de origem histórica. Do mesmo modo ele se estendeu constituindo setores novos, comercializados, industrializados: os lazeres, a cultura e a arte dita 'moderna', a urbanização. (...) o capitalismo só se manteve estendendose ao espaço inteiro" (LEFEBVRE, [1972] 2008, p.117, grifo do autor)
\end{abstract}

Nessa lógica onde o espaço passa a ser central para a acumulação capitalista, pode-se dizer que ele, assim como qualquer outra mercadoria produzida, contém e dissimula relações sociais capitalistas. Em outra obra, o autor francês assinala que a partir das crises do setor produtivo do período fordista-keynesiano, o espaço passa a ser central para a sobrevida do modo de produção capitalista:

\begin{abstract}
a produção do espaço, em si, não é nova. Os grupos dominantes sempre produziram este ou aquele espaço particular, o das antigas cidades, o dos campos (aí incluídas as paisagens que em seguida parecem "naturais"). $\mathbf{O}$ novo é a produção global e total do espaço social. Essa extensão enorme da atividade produtiva realiza-se em função dos interesses dos que a inventam, dos que a gerem, dos que dela se beneficiam. (...) Ele [o capitalismo] encontrou um novo alento na conquista do espaço, em termos triviais, na especulação imobiliária, nas grandes obras (dentro e fora das cidades), na compra e na venda do espaço. E isso à escala mundial. (LEFEBVRE, [1970] 1999, p.142-143, grifos nossos)
\end{abstract}

No mundo contemporâneo, intensificam-se as contradições e conflitos da produção social do espaço quando ele é capturado pelo capital financeiro e rentista para atuar como lócus privilegiado de acumulação direta de capital. Nesse sentido, o espaço mobilizado como riqueza imobiliária e financeira passa a ter seu preço elevado, fato que pode ser notado a partir de 2007 nas cidades brasileiras. O imbricamento dessas duas dimensões, segundo Pereira (2017), “cria liquidez e manipula a raridade do espaço, favorecendo a produção do espaço e do valor a tal ponto que ela alcança o nível da economia mundial. A propriedade

${ }^{103}$ Ibid., p. 28, grifo nosso 
da terra e propriedade do dinheiro se ativam mutuamente na mobilização do espaço pelo capital" 104 . Nessa combinação,

\begin{abstract}
A financeirização da produção expande-se mobilizando a riqueza imobiliária e mobiliária, como patrimônios rentistas. A capitalização desses direitos de propriedade expressos em um enorme conjunto de títulos imobiliários, hipotecários, dívida pública, ações, etc. se ajusta em favor de uma lógica rentista, criando mais do que uma complexidade econômica nova. Pela fusão desses direitos patrimoniais, conectam-se o imobiliário e as extensões do capital financeiro globalizado. Cria-se uma força política inédita formada pela coalizão de frações proprietárias da classe dominante capaz de restaurar a dominação capitalista a nível mundial. (PEREIRA, 2017, pp.195-196).
\end{abstract}

$\mathrm{Na}$ atualidade, a produção desigual e diferencial do espaço no urbano se intensifica com a associação entre imobiliário e financeiro. Rufino (2017) aponta que dentre as especificidades da acumulação capitalista a partir do imobiliário estão a "dependência estrutural dos financiamentos (dimensão econômica) e relevância da renda imobiliária (dimensão espacial) $"$ "105. Nesse contexto, o sistema de crédito torna-se ferramenta fundamental, uma vez que "ao adiantar recursos ociosos àqueles que não dispõem desses recursos em determinado ponto do tempo, o sistema de crédito permite uma compatibilização entre diferentes temporalidades do processo de acumulação"106. No Brasil, a abertura de capital fez com que as incorporadoras sofressem pressões de toda ordem de seus investidores para intensificar a expansão da produção. Por outro lado, o que garantiu essa expansão sem precedentes foi a disponibilização e facilitação de crédito imobiliário habitacional para segmentos de renda mais populares que, no contexto brasileiro, só foi possível graças a ação do Estado devido à conjuntura macroeconômica favorável, com a modernização nos marcos regulatórios e de política de subsídios com o Programa Minha Casa Minha Vida (PMCMV), fatos estes que serão largamente abordados no capítulo dois. Esse conjunto de fatores foram fundamentais para que as grandes incorporadoras de capital aberto expandissem seus leques de atuação ao mesmo tempo que deram segurança de retorno financeiro aos investidores. Rufino (2017) ainda aponta que

a dependência estrutural de financiamentos facilitou a forte e rápida penetração do capital financeiro, favorecendo processos de centralização de capital no setor. Nesse processo, o capital financeiro, além de capital de empréstimo, aparecerá na forma de ações e em uma diversidade de títulos imobiliários, passando a interferir de maneira direta na gestão das

\footnotetext{
104 PEREIRA, 2017, p.187, grifo nosso

${ }^{105}$ RUFINO, 2017, p. 216

${ }^{106}$ SANFELICI, 2013a, p. 29
} 
empresas, impondo a racionalidade das finanças de um crescimento contínuo no setor (RUFINO, 2017, p. 216)

Decorre desse processo uma forte tensão, onde, de um lado, está a necessidade de expansão desenfreada em que se reivindica mais do que a economia pode dar para satisfazer a crescente margem de rendimento dos investidores acionistas em situação de exterioridade à produção e, de outro lado, a gestão dos riscos que decorrem do crescimento exponencial num curto espaço de tempo, o que demanda uma rápida expansão geográfica da produção não apenas para as áreas mais valorizadas de outras metrópoles e cidades médias brasileiras onde não atuavam, o que poderia ser compensada de alguma forma pela expertise de se atuar tradicionalmente para os segmentos de médio e alto padrão. Essa expansão geográfica deveria vir necessariamente acompanhada da expansão para outros segmentos econômicos mais populares, na maioria dos casos fora do know-how dessas empresas.

Como consequência desse processo o que se nota no nível mais imediato e até mesmo na observação da paisagem contemporânea das metrópoles brasileiras é uma eclosão de grandes empreendimentos imobiliários de mercado com centenas de unidades em todos os espaços das metrópoles, porém com maior incidência e impacto nas áreas menos valorizadas, sobretudo porque ocupam antigas glebas ociosas oriundas dos processos de desindustrialização. Segundo Volochko, “As diferenças entre 'produtos imobiliários' em termos da rentabilidade, das características dos projetos e da escolha dos terrenos giram em torno da necessidade de se aumentar o volume das unidades habitacionais lançadas quanto mais ‘popular' for o imóvel" ${ }^{\text {107 }}$. Nesse sentido, a generalização da forma-condomínio que, a rigor, é a generalização da propriedade imobiliária fragmentada em múltiplas parcelas para todo território das metrópoles, desencadeia um insano processo de capitalização da propriedade, onde a captura dos ganhos advindos do conjunto desses empreendimentos serão auferidos na forma de renda imobiliária e financeira (mobiliária), na esfera de distribuição da mais-valia global, mas também no plano imediato a partir dos lucros advindos da valorização do espaço. Como indica Rufino (2017), “os ganhos advindos da renda imobiliária serão exacerbados e capturados em parte pelos proprietários de ações e títulos imobiliários. Assim, a projeção de ganhos financeiros (capital fictício) impulsiona a elevação da renda imobiliária e amplia sua histórica relevância no setor" 108 .

\footnotetext{
107 VOLOCHKO, 2015b, p.105

${ }^{108}$ RUFINO, 2017, p. 2016
} 
Cabe aqui ressaltar alguns aspectos desses mecanismos de capitalização na atualidade: o primeiro, relacionado a propriedade mobiliária, diz respeito à capitalização auferida pelas incorporadoras através da captura de recursos via mercado financeiro mundial e que deverá gerar rendimentos sob a forma de renda financeira. $\mathrm{O}$ segundo, relacionado à propriedade imobiliária, diz respeito à capitalização auferida pelos altos preços que os imóveis passam a alcançar. Esses preços relacionam-se fortemente com a disponibilidade e prazos de financiamentos, consolidado em políticas públicas como o Programa Minha casa Minha Vida. São, portanto, derivados da reorganização das finanças e dos financiamentos, coordenados principalmente por esforços na esfera nacional, onde são definidas as condições de maior atração do capital financeiro internacional em forte medida determinada pela captura de fundos paraestatais. Esses mecanismos de capitalização engendrados na esfera nacional, precisam se articular à reprodução imediata do capital no canteiro. Aqui as estratégias de ampliação dos ganhos se associam fortemente às políticas públicas municipais, que vão permitir a realização de preços elevados em áreas antes não exploradas pelo mercado imobiliário.

Os altos preços inicialmente associados aos imóveis e, na sequência, à terra, são a expressão máxima do funcionamento da propriedade imobiliária como capital fictício, que transfere rendimentos que poderão (ou não) ser auferidos no futuro para o tempo presente. “Atualmente, é em torno da captura de parte da mais-valia, sob a forma de juro e de renda, que emerge uma nova coalizão das finanças mundializadas, que abarca o financeiro e a produção imobiliária"109. Nesta lógica, ambos rendimentos são mobilizados enquanto patrimônio rentista.

No capítulo seguinte, abordaremos como se estabeleceu de forma mais concreta no contexto brasileiro as articulações entre as finanças, as grandes incorporadoras nacionais e o Estado em suas várias esferas, dando destaque à articulação entre as incorporadoras e o mercado financeiro a partir da abertura de capital na bolsa em meados da primeira década do século XXI, mas também os processos que se vem se desencadeando desde a década de 1990 no âmbito nacional a partir da criação de novos marcos regulatórios para o setor, fornecendo toda a segurança jurídica para que os investimentos financeiros possam atingir os rendimentos esperados. Abordaremos também as articulações realizadas na esfera local entre as grandes incorporadoras e o governo municipal carioca que proveu uma série de

${ }^{109}$ PEREIRA, 2017, p. 185 
mecanismos legais - desde a criação de novas normas urbanísticas e edilícias, até a flexibilização da legislação local -, políticas públicas de segurança, a construção de grandes novas infraestrutura e reapropriação das antigas, promovendo as condições gerais para a formação de novas fronteiras de acumulação a partir da produção do espaço.

A maioria desses grandes empreendimentos necessitam que a figura do Estado, em suas diferentes esferas federativas, reforce a regulamentação da propriedade, tanto do ponto de vista urbano, quanto do ponto de vista jurídico e financeiro para que esses se realizem com sucesso, ou seja, viabilizem que os preços de mercado alcancem sua máxima rentabilidade. Abordaremos em seguida como a convergência entre capital imobiliário e Estado torna não apenas possível, mas intensos os mecanismos de valorização e capitalização da terra. No caso particular do Rio de Janeiro, também abordaremos, ainda que de passagem, o impacto dos megaeventos esportivos internacionais nesse processo. 


\section{CAPÍTULO 02 |}

A confluência entre mercado financeiro, imobiliário e Estado na formação de novas fronteiras imobiliárias: mecanismos de capitalização 
A primeira década dos anos 2000 é marcada por uma profunda reestruturação no setor imobiliário brasileiro. Como já apontado, este setor expandiu-se com extrema pujança, elevando a novos patamares jamais presenciados o volume de lançamentos e de lucros e rendimentos auferidos. Como se pode observar em diversas cidades brasileiras - e de maneira mais intensa nas áreas metropolitanas -, esse boom engendrou de maneira acelerada profundas transformações em todos esses espaços. A maneira como se desencadeou a magnitude dessas transformações não seria possível sem uma poderosa articulação entre os principais agentes da produção do espaço contemporânea, a saber, o mercado financeiro mundial, as principais incorporadoras nacionais e o Estado, onde cada um passa a ter um papel crucial nessas transformações, ainda que as incorporadoras apareçam como a face mais visível desse processo. Essas articulações são decorrentes dos arranjos em diferentes escalas - do global ao local - tendo como finalidade a acumulação de capital a partir dos rendimentos obtidos na produção do espaço a partir da capitalização das propriedades mobiliária e imobiliária. Nesse sentido, este capítulo dará destaque a essas articulações, buscando compreender o papel de cada agente na produção do espaço na atualidade, tendo como perspectiva as transformações ocorridas na cidade do Rio de Janeiro no período estudado.

\subsection{Abertura de capital das grandes incorporadoras e estratégias gerais do setor imobiliário}

De início, é necessário dizer que o período compreendido entre os anos de 2005 e 2007 é chave em todo esse processo. O que se presenciou neste ínterim foi a abertura de capital na bolsa de valores das maiores e mais importantes incorporadoras do setor imobiliário brasileiro, bem como a adesão ao Novo Mercado ${ }^{110}$ pelas mesmas. Incorporadoras como PDG, Cyrela e MRV, só para citar alguns exemplos, fizeram suas ofertas públicas iniciais $\left(I P O^{111}\right)$, a partir do lançamento de papéis no mercado financeiro, tendo por objetivo a captura de recursos. Conforme apontado por Miele (2007), esse processo de captação a um

\footnotetext{
110 Segundo dados da Bovespa, o Novo Mercado é um padrão internacional de governança corporativa e de transparência cujo receituário deve ser implementado pelas empresas que abrem capital na Bolsa. Tal padrão é exigido pelos investidores e é recomendado a empresas que pretendam realizar ofertas grandes e direcionadas a qualquer tipo de investidor. Dentre as regras principais do Novo Mercado podemos citar a composição do capital exclusivamente por ações ordinárias com direito a voto, auditorias internas, divulg ações periódicas com resultados, fatos relevantes, negociações, etc.

${ }^{111}$ Initial Public Offering ou Oferta Pública Inicial é uma sigla que designa a abertura de capital feita por uma empresa na Bolsa de Valores, ou seja, indica a primeira oferta de ações no mercado financeiro de uma determinada companhia.
} 
custo baixo pelas incorporadoras tem por prioridade "a realização de incorporação, compra de terrenos e lançamentos imobiliários bem como aquisição de outras empresas deste ramo que sejam proprietárias de terrenos e que detenham empreendimentos já lançados no mercado que interessem a esses grandes empreendedores"112 . Além disso, o autor ainda faz um importante destaque, onde

\begin{abstract}
os montantes de capital absorvido por essas empresas não são utilizados para a construção de novos empreendimentos. A construção ainda continua sendo financiada pelo Sistema Financeiro da Habitação (SFH). A captação de recursos através de vendas de ações em bolsa aumenta o patrimônio da empresa e permite também que seu crescimento e lucro cresçam consideravelmente, o que permite que ela consiga mais dinheiro junto ao SFH para realizar a construção dos empreendimentos imobiliários. Assim, a grande aplicação desses recursos é em compra de terrenos e incorporações imobiliárias" (MIELE, 2007, p. 121)
\end{abstract}

É importante apontar, no entanto, que o momento encontrado pelas grandes incorporadoras como ideal para abertura de capital na bolsa de valores não é fortuito ou fruto do acaso. Como já discutido e detalhado a partir das ideias de Paulani (2012) no item 1.3 deste trabalho, desde a década de 1980, é notável o crescimento do movimento de financeirização no Brasil, que transformou o país no que a autora denomina como plataforma internacional de valorização financeira dentro de um contexto mundial de acumulação capitalista.

Como efeito desse cenário macroeconômico que caracteriza a década de 1990, pode-se elencar algumas medidas tomadas nesse sentido em prol do setor imobiliário com o mesmo propósito. A partir da década de 1990, como aponta Faulhaber (2015), o Estado brasileiro cria uma série de instrumentos financeiros e arcabouço jurídico específicos para dar maior segurança jurídica e liquidez às transações imobiliárias. Porém, como aponta Shimbo (2012), a aproximação entre o capital financeiro e o setor imobiliário, neste período, se deu de forma truncada (abordaremos esses pontos com mais detalhe no capítulo 3). Dessa forma, a partir de meados da década de 2000, o setor passa a crescer consideravelmente.

o setor imobiliário, por meio de suas organizações de classe, participou da elaboração do SFI e da criação dos Fundos de Investimentos Imobiliários, como alternativas ao financiamento e atração de recursos ao mercado brasileiro. Nesse mesmo contexto, complementando ao SFI, são criadas uma série de outros instrumentos legais, que segundo os empresários, visam estabelecer uma maior segurança jurídica à atuação do setor, como a instituição do Valor Incontroverso, a Alienação Fiduciária e as SPE's. As legislações complementares ao SFI criaram além destes parâmetros de regulação da atividade da construção civil e incorporação, um repertório amplo de dispositivos que visavam dar mais liquidez ao ativo imobiliário, para a consequente entrada no mercado de capitais, como as Cédulas de

${ }^{112}$ MIELE, 2007, p. 121 
Crédito Imobiliário, as Letras de Crédito Imobiliário e os Certificados de Recebíveis Imobiliários" (FAULHABER, 2015, pp. 41-42)

O "conjunto de transformações institucionais e regulatórias que permitiram não apenas impulsionar o crédito habitacional, mas também tornar o circuito imobiliário (compreendido de forma ampla, incluindo aqui o crédito ao comprador final dos imóveis) mais atrativo aos investidores financeiros"113 é, para Sanfelici (2013b), o aspecto fundamental para compreensão das transformações ocorridas nos negócios imobiliários brasileiros.

Tavares (2008) aponta que outros fatores, além de melhores condições de crédito, também favoreceram o processo de abertura de capital e captura de novos investidores: "o momento favorável do mercado de ações; a adesão ao Novo Mercado; a entrada de investidores estrangeiros" ${ }^{\text {114 }}$. Todo cenário favorecia para que o próximo passo - a abertura de capital na bolsa de valores - pudesse ser dado pelas grandes incorporadoras.

Embora algumas companhias do setor imobiliário já tivessem iniciado suas transações na Bolsa anteriormente, é a partir de 2006 que há um grande movimento de abertura de capital por parte das grandes incorporadoras para aumentar significativamente o volume de capital, expandindo, assim, o poder de investimento dessas empresas. Um fator importante para o desenvolvimento das operações foi, segundo pesquisa exploratória de Tavares (2008), “a adesão das empresas emissoras ao Novo Mercado, comprometendo-se a adotar melhor padrão de procedimentos de governança corporativa e melhorar a qualidade de informações disponibilizada aos investidores" ${ }^{115}$, como já mencionado. Na realidade, as reformulações internas e a rápida e volumosa injeção de capital que essas empresas sofrem são de tal ordem, que elas acabam por se configurar numa nova empresa, guardando apenas "a razão social e o currículo da original"116.

Shimbo (2012) aponta que, influenciadas pelo "case" norte-americano de negócios imobiliários - o real estate -, as incorporadoras brasileiras passam a recorrer a uma série de instrumentos financeiros para angariar recursos. Nesse sentido, segundo Royer (2009), contaminado pelas múltiplas acepções de "real estate", o negócio imobiliário "passou a configurar um novo modo de ser da reprodução do capital imobiliário, demandando a estruturação de um sistema de crédito a serviço da valorização imobiliária e da acumulação

\footnotetext{
${ }^{113}$ SANFELICI, 2013b, p. 04

${ }^{114}$ TAVARES, 2008, p. 67

${ }^{115}$ Ibid., p. 67

${ }^{116}$ LIMA JR., 2007, p. 12
} 
financeira do capital" ${ }^{117}$. Shimbo alerta que no caso brasileiro desenvolveu-se apenas um aspecto do modelo norte-americano: a adesão ao mercado de capitais via captação direta de recursos para a incorporadora, ou seja, os capitais que entravam financiavam a estrutura da empresa.

\footnotetext{
No caso das empresas construtoras e incorporadoras com atuação no setor residencial, diferentemente do caso norte-americano, a unidade habitacional não passou a ser transacionada, ela mesma, no mercado financeiro, mas sim as ações de determinada empresa que atua na produção e incorporação de empreendimentos residenciais. Ou seja, configurou-se aqui um real estate à moda brasileira (SHIMBO, 2012, p. 68)
}

O setor imobiliário sempre teve como característica o predomínio de empresas pequenas e médias, de atuação local ou regional e de gestão familiar. Tal característica se torna mais evidente no contexto dos países latino-americanos, como o Brasil. Porém, o que se vê a partir desse momento é a intensificação das relações capitalistas no setor - sobretudo a partir das empresas que tinham atuação privilegiada nas metrópoles de São Paulo e Rio de Janeiro - e a busca por um grande volume de recursos no mercado financeiro, onde se orbitam capitais de todo o mundo, para realizar suas operações. Essa articulação entre o imobiliário e o financeiro entre os anos de 2005 e 2007 produziu um "rearranjo dos vínculos escalares como consequência do adensamento e intensificação das relações econômicas travadas entre agentes que privilegiam diferentes escalas geográficas de operação" ${ }^{118}$. A entrada de investidores estrangeiros no controle acionário dessas empresas aponta "para uma articulação diferenciada entre as escalas local, nacional e global na produção dos espaços metropolitanos" $" 119$.

A partir do momento que as incorporadoras abrem capital na bolsa, os números do setor imobiliário e da construção civil mudam de patamar. Segundo reportagem do jornal Folha de São Paulo em 28 de março de 2007, intitulada "Imóveis e construção lideram abertura de capital neste ano", os setores de construção civil e imobiliário concentraram $50 \%$ do montante de $\mathrm{R}$ \$ 8,83 bilhões já emitidos em ações em 2007. Das 17 emissões (entre abertura de capital e emissões secundárias) até o momento examinado, 11 ficaram com as companhias dos setores. Em 2006, o segmento respondeu por 18,9\% das ofertas de ações realizadas, concentrando a maior fatia dos R \$ 31,3 bilhões captados ${ }^{120}$. Segundo Sanfelici,

\footnotetext{
117 ROYER, 2009, p. 41

118 SANFELICI, 2013b, p. 03

${ }^{119}$ Ibid., p. 03

${ }^{120} \mathrm{https}$ ://acervo.folha.com.br/leitor.do?numero=17124\&anchor=5229898\&origem=busca\&pd=3d1ec0db261
} 
o volume de capital levantado por incorporadoras e construtoras no biênio 2006/7 mediante a emissão de ações e debêntures foi surpreendente: mais de $\mathrm{R} \$ 15$ bilhões em ações e quase $\mathrm{R} \$ 2$ bilhões em debêntures, a maior parte (em torno de $70 \%$ segundo entrevistas e matérias de jornais) adquirida por grandes investidores institucionais estrangeiros3. O uso desses recursos se materializou nos dados de unidades lançadas e valor geral de vendas (VGV) lançado entre 2005 e 2010, período que corresponde às transformações de maior profundidade no setor (SAFELICI, 2013b, p. 05)

Tabela 1. Incorporadoras brasileiras listadas na BOVESPA

\begin{tabular}{|c|c|c|c|c|c|c|c|c|}
\hline Empresa & $\begin{array}{c}\text { Código } \\
\text { Bovespa }\end{array}$ & Ano & $\begin{array}{c}\text { I.P.O } \\
\text { (R\$ milhões) }\end{array}$ & 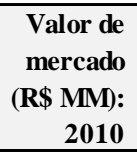 & $\begin{array}{r}\begin{array}{r}\text { Valor de } \\
\text { mercado }\end{array} \\
\text { (R\$ MM): } \\
2015 \\
\end{array}$ & $\begin{array}{r}\text { Patrimônio } \\
\text { Líquido } \\
\text { (R\$ MM): } \\
2010 \\
\end{array}$ & $\begin{array}{r}\text { Patrimônio } \\
\text { Líquido } \\
\text { (R\$ MM): } \\
2015 \\
\end{array}$ & $\begin{array}{r}\text { Atua no } \\
\text { RJ? }\end{array}$ \\
\hline Brookfield (Brascan) & BISA3 & 2006 & 940 & $4.041,6$ & $2.116,0$ & $2.605,1$ & $1.908,0$ & $\bar{S}$ \\
\hline CCDI & CCDI3 & 2007 & 556,8 & $1.039,5$ & N/I & 765,9 & N/I & $\mathrm{N}$ \\
\hline CR2 & CRDE3 & 2007 & 353,7 & 304,4 & 87,1 & 395,1 & 236,0 & $S$ \\
\hline Cyrela/Living & CYRE3 & 2005 & 511 & $9.608,5$ & $4.045,0$ & $4.201,7$ & $5.887,0$ & $\mathrm{~S}$ \\
\hline Direcional & DIRR3 & 2009 & N/I & $1.852,1$ & 874,3 & 782,8 & $1.646,0$ & $\mathrm{~S}$ \\
\hline Even & EVEN3 & 2007 & 460 & $2.304,9$ & 870,7 & $1.303,1$ & $2.159,0$ & S \\
\hline Eztec & EZTC3 & 2007 & 542,1 & $1.770,9$ & $2.591,0$ & $1.093,6$ & $2.702,0$ & $\mathrm{~N}$ \\
\hline Gafisa/Tenda & GFSA3 & 2006 & 494,4 & $6.341,1$ & 763,6 & $3.545,4$ & $3.095,0$ & $\mathrm{~S}$ \\
\hline Helbor & HBOR3 & 2007 & 267,3 & $1.337,7$ & 355,6 & 647,2 & $1.382,0$ & S \\
\hline JHSF & JHSF3 & 2007 & 432,4 & $1.432,0$ & 572,2 & 960,2 & $2.645,0$ & $\mathrm{~N}$ \\
\hline João Fortes & JFEN3 & 2007 & $\mathrm{~N} / \mathrm{I}$ & $1.275,0$ & 758,2 & 316,8 & 970,9 & $\mathrm{~S}$ \\
\hline MRV & MRVE3 & 2007 & $1.071,1$ & $8.277,9$ & $4.886,0$ & $2.663,3$ & $4.776,0$ & S \\
\hline PDG & PDGR3 & 2007 & 483 & $12.458,0$ & 126,9 & $5.613,1$ & $1.934,0$ & S \\
\hline Rodobens & RDNI3 & 2007 & 448,5 & 893,2 & 302,4 & 668,4 & 818,4 & $\mathrm{~N}$ \\
\hline Rossi & RSID3 & 2006 & 612,5 & $4.550,6$ & 53,8 & $2.455,7$ & $1.226,0$ & $S$ \\
\hline Tecnisa & TCSA3 & 2007 & 649,9 & N/I & 411,1 & N/I & $1.667,0$ & $\mathrm{~N}$ \\
\hline Trisul & TRIS3 & 2007 & 318,8 & 638,0 & 182,6 & 509,8 & 510,0 & $\mathrm{~N}$ \\
\hline Viver (InPar) & VIVR3 & 2007 & 756 & 998,5 & 5,9 & $1.072,3$ & 184,7 & $\mathrm{~N}$ \\
\hline
\end{tabular}

Fonte: elaboração do autor a partir de dados da BOVESPA, Tavares (2008), Fix (2011) e Faulhaber (2015)

Após a captação desses recursos financeiros, os sinais de crescimento foram percebidos em pouco tempo. Em 2005, apenas a Cyrela tinha rompido a barreira de R\$1bi em VGV/ano. Curiosamente, uma das primeiras a negociar suas ações na bolsa a partir do mesmo ano. Até então, as marcas mais expressivas em termos de alcance de VGV era da Gafisa (R\$ 682 milhões) e PDG (R \$ 592 milhões). Em relação ao número de unidades lançadas, a média figurava entre 2000 e 3000 unidades/ano, número que oscilava moderadamente dentro desse intervalo. A partir de 2006, no entanto, esses números explodem e as empresas dão saltos cada vez maiores de produtividade e vendas. Em 2011, a PDG atinge a marca de R \$11,374 bi em VGV e mais de 40mil unidades lançadas. No ano anterior, a MRV bate o recorde de lançamento no setor alcançando a marca de mais de 50 mil unidades. Essa alta performance 
que se nota a partir de 2009 está atrelada ao lançamento do Programa Minha Casa Minha Vida. No entanto, a partir de 2012 as incorporadoras passam a ter problemas para cumprir os prazos de suas obras e, com isso, passam também a não performar de acordo com a expectativa de seus investidores. Um dos motivos que explica esse quadro é que o crescimento vertiginoso e a expansão para outros mercados acarretaram problemas logísticos de fornecimento de materiais de construção, conflitos com legislação locais e até mesmo dificuldades em se estabelecer nas concorrências locais de mercado de terras. No caso da PDG, influenciou também os escândalos de corrupção dentro da empresa, o que afugentou seus investidores, comprometendo seriamente a saúde financeira da empresa. O desempenho global de três das principais incorporadoras no período de 2005 e 2015 pode ser compreendido com mais clareza a partir dos gráficos abaixo:

Gráfico 1. Número de unidades lançadas no Brasil por incorporadora (2005-2015)

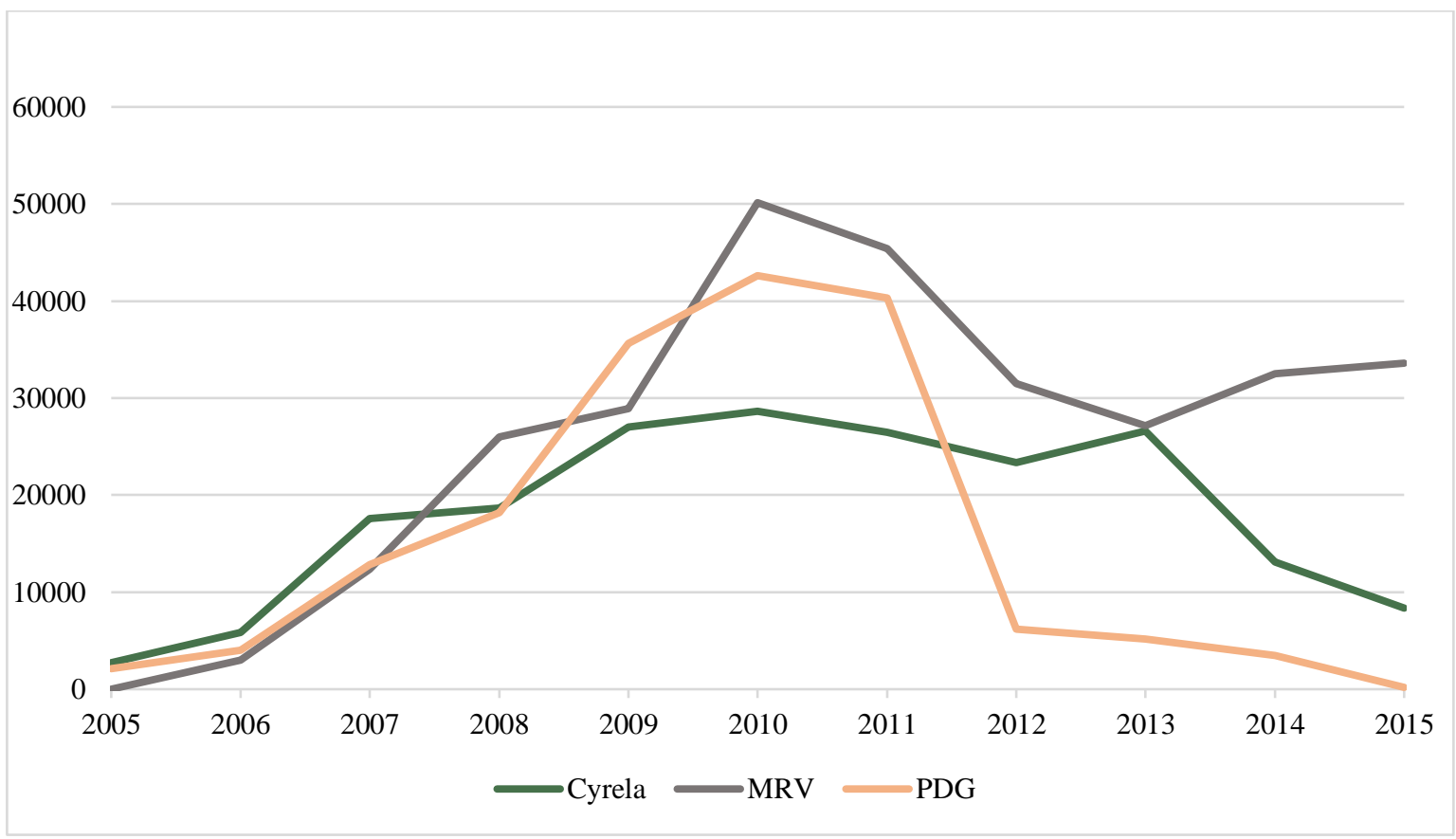

Fonte: elaboração do autor a partir de dados dos relatórios disponibilizados pelas empresas em seus sites 
Gráfico 2. VGV (R \$MM) por incorporadora (2005-2015)

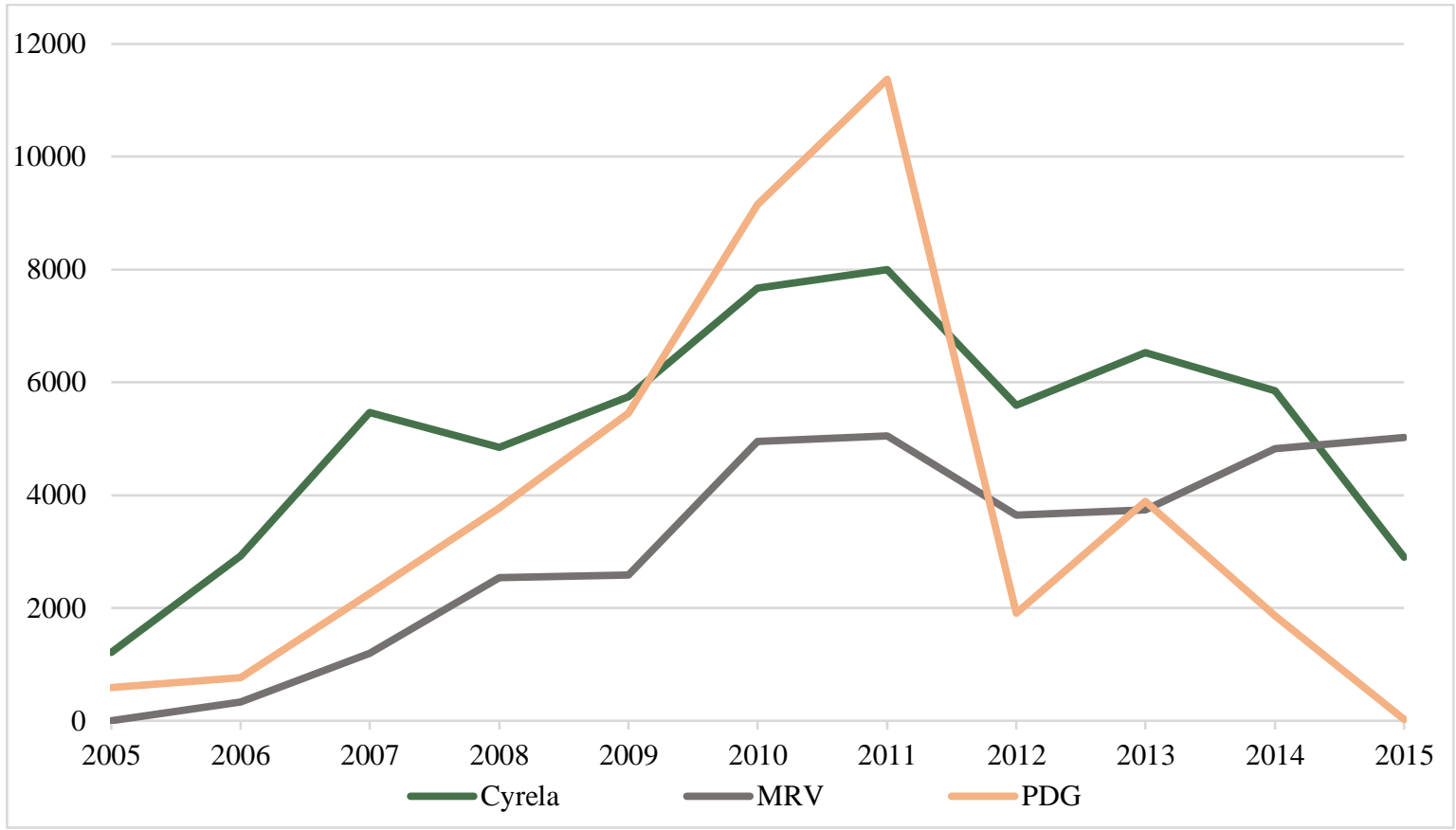

Fonte: elaboração do autor a partir de dados dos relatórios disponibilizados pelas empresas em seus sites

Analisando ainda os gráficos acima, tanto no que diz respeito às unidades lançadas quanto ao valor de vendas alcançadas, é notável a forte flutuação e não regularidade tanto de produção quanto de ganhos ano após ano. Em parte, isso poderia ser explicado pelo fato de muitas empresas de capital aberto terem expandido sua produção para outros estados brasileiros, o que pode ter feito as empresas, em determinados momentos, privilegiar esta ou aquela região específica de atuação, mediante suas estratégias particulares. Contudo, tal fenômeno é observado na análise da produção global dessas empresas em todo território nacional e não apenas em cidades ou metrópoles específicas. Isso nos leva a uma discussão de cunho mais teórico que reforça a tese de que a indústria imobiliária guarda uma característica particular de produção frente a outros tipos de produção de mercadorias. A questão da propriedade da terra - ora como obstáculo, ora como impulso - e, consequentemente, da renda capitalizada, é central neste ramo produção, bem como o tempo de realização desse capital, conferindo a ela uma característica particular. A partir dessa visão, discorda-se da visão clássica imputada por alguns pesquisadores dessa área do conhecimento de que a indústria da construção é uma indústria atrasada. Essa forma particular de valorização do capital a partir do imobiliário ocorre combinando dois processos de captura de mais-valor, seja "pelo trabalho diretamente incorporado na produção imediata da construção [valorização], como pelo desenvolvimento de condições gerais que resulta em 
elevação do preço do imóvel no mercado [capitalização] ${ }^{121 "}$. Pela combinação dessas formas de captura de mais-valor, pode-se superar a aparente ideia de que a construção é uma indústria atrasada. Neste sentido, pode-se dizer que:

\begin{abstract}
"decorre daí uma "associação" entre proprietários e capitalistas na produção imobiliária, que dão pouca importância ao aumento da produtividade (aumento da quantidade produzida com redução do valor individual) do trabalho na construção, mas abusam da exploração extensiva do trabalho (aumento da quantidade produzida sem redução do valor individual) pela utilização de um número cada vez maior de trabalhadores com reduzida qualificação. A consequência é que o processo de trabalho na construção se particulariza no processo de valorização, por ser potenciado pela valorização imobiliária e não concorrer para a redução do tempo de trabalho social" (PEREIRA, 1988, p. 15)
\end{abstract}

É importante pontuar, no entanto, que a abertura de capital não homogeneíza essas empresas apesar de terem que cumprir determinados requisitos estabelecidos pelo Novo Mercado e de proporcionar retornos financeiros maiores e mais rápidos para seus acionistas. Há, no interior de cada empresa, diferentes estruturas acionárias que podem interferir nas estratégias de atuação, tanto do ponto de vista da expansão territorial, quanto da forma de associação a outras empresas e até mesmo dos segmentos econômicos que a empresa irá abranger.

Dentro desse grupo de empresas de capital aberto, pode-se observar a existência de pelo menos dois subgrupos distintos no que diz respeito à estrutura acionária: um primeiro grupo de empresas que, apesar de possuir um controlador acionário, tem suas ações "pulverizadas" no mercado com pequenas participações sob controle de diversos proprietários. $\mathrm{O}$ caso mais emblemático é o da PDG que, até a data de consulta para esta pesquisa ${ }^{122}$, possuía cerca de $34 \%(22,38 \%+11,66 \%)$ de suas ações sob controle acionário de duas subsidiárias do mesmo Fundo de Investimento - a Vinci Partners - e o restante das ações fragmentadas no mercado. Ao passo que, de outro lado, existem as empresas que mesmo com capital aberto, possuem o controle na figura do "dono" original e de sua família sobre a maior parte das ações. Neste caso, essas empresas veem na abertura de capital uma possibilidade de aumentar o capital da empresa para expansão dos investimentos sem que se perca o controle de todo o processo decisório. Como exemplo, pode-se citar a MRV, dirigida pelo seu sócio fundador Rubens Menin, que detém, sozinho, 33,6\% das ações da empresa. No período estudado, algumas empresas retiraram suas ações do mercado e voltaram a ter o controle restrito, como a canadense Brookfield (em 2017 passou a se chamar Tegra) que encerrou suas ofertas de ações no Novo Mercado em 2014. Outra característica importante a ser ressaltada é a

${ }^{121}$ PEREIRA, 1988, pp. $15-16$
${ }^{122}$ Em $19 / 11 / 2018$ 
diversidade de investidores dessas empresas, que vão desde pessoas físicas e jurídicas diversas, bancos nacionais e estrangeiros, fundos de pensão, private equity, etc., como apontado por Shimbo (2012). Para Fix (2011),

\begin{abstract}
o setor é difícil de ser inteiramente capturado por capital internacional, ao menos em um primeiro momento. Os conhecimentos locais, a pressão sobre o poder público (executivo, legislativo e judiciário), a falta de articulação com a economia mundial, a pouca proximidade entre os mercados de capitais e o mercado imobiliário são alguns dos fatores que dificultam a metamorfose completa (FIX, 2011, p. 150)
\end{abstract}

É importante deixar aqui registrado que essas informações sobre estruturas acionárias das empresas incorporadoras são de difícil precisão. Algumas informações lançadas nos relatórios das empresas, na página da Bovespa (BM\&F Bovespa) ou até mesmo em sites especializados no mercado de ações, como a EconoInfo, trazem informações conflitantes. No caso de empresas que encerram sua participação na bolsa, fecham-se também a maioria das informações sobre as mesmas. Outro fato interessante de notar nos relatórios de resultados é que, no momento de forte expansão do setor, as informações listadas são de mais diretas e de fácil leitura, ainda que genéricas. No momento de crise, os mesmos tipos de informação não ficam tão claros. No caso dos fundos de investimentos a investigação se torna ainda mais penosa, pois os mesmos mantem em sigilo a identidade e nacionalidade de seus beneficiários e até mesmo de seus diretores executivos.

Após a grande injeção de capital via mercado financeiro, essas empresas expandiram exponencialmente seus tamanhos e poder de investimento em curto prazo e para isso precisaram mostrar resultados e retorno rápido para seus acionistas. Isso passava, obviamente, por ampliar o volume de produção de novos empreendimentos. Porém, a ampliação dentro de seus respectivos nichos de produção, ou seja, majoritariamente para os setores de renda média, média-alta e alta, não seria suficiente para a "saciar" o mercado. A expansão para outros segmentos era o caminho a ser tomado. Isso significou, na prática, produzir habitação para uma faixa de renda que, "ao menos teórica e discursivamente, corresponderia ao déficit habitacional"123.

Os esforços do mercado imobiliário para a produção de unidades residenciais mais acessíveis para faixas de renda mais baixas surtiram efeito e o segmento econômico contemplou uma demanda que não era anteriormente absorvida pelos agentes do mercado, mas que tampouco se referia, em sua maioria, ao déficit habitacional brasileiro (SHIMBO, 2012, p. 75)

${ }^{123}$ SHIMBO, 2012, p. 74 
Algumas empresas optaram por uma postura mais agressiva no mercado, lançando produtos em diversos segmentos econômicos, comprando terrenos em diversas localidades para formação de um banco de terras (landbank), para além do eixo Rio-São Paulo, expandindo sua atuação para outros estados brasileiros com a força da marca, como a PDG, que adquiriu empresas que atuavam em outros segmentos e depois as fundiu à marca, embora algumas parcerias (joint ventures ${ }^{124}$ ) também tenham sido realizadas. Acerca deste último ponto, outras empresas como a Cyrela também diversificaram, expandiram para além de seu mercado de origem e formaram seus respectivos landbanks. Contudo, elas criaram subsidiárias para atuarem nos nichos de mercado econômico e popular, sobretudo do PMCMV, além de fazerem parcerias com empresas de pequeno e médio portes, muitas vezes locais, que possuíam know-how tanto na produção para determinados segmentos econômicos, quanto no domínio do mercado da região para onde se expandiram, bem como de suas características culturais próprias e das particularidades do mercado de terras local, ampliando seu leque de atuação com mais segurança. Além disso, as parcerias com essas empresas são fundamentais para acelerar os trâmites de aprovação de projetos junto ao governo local. No caso da MRV, empresa que tradicionalmente atua no segmento econômico, com largo know-how, expandiu sua atuação e intensificou sua produção, sendo uma das principais empresas em volume de contratos do PMCMV (12\% entre 2011 e 2012). Outras empresas optaram por não expandir sua atuação para outros segmentos econômico e outros estados brasileiros, intensificando a produção e lançamento de novos produtos imobiliários dentro do seu métier.

124 Segundo o dicionáriofinanceiro.com, joint venture é um acordo entre duas ou mais empresas que estabelece alianças estratégicas por um objetivo comercial comum, por tempo determinado. As companhias concordam em unir seus recursos para o desenvolvimento de um negócio conjunto e dividem os resultados, sejam eles lucros ou prejuízos. 
Tabela 2. Fusões, aquisições e parcerias realizadas pelas grandes incorporadoras de capital aberto

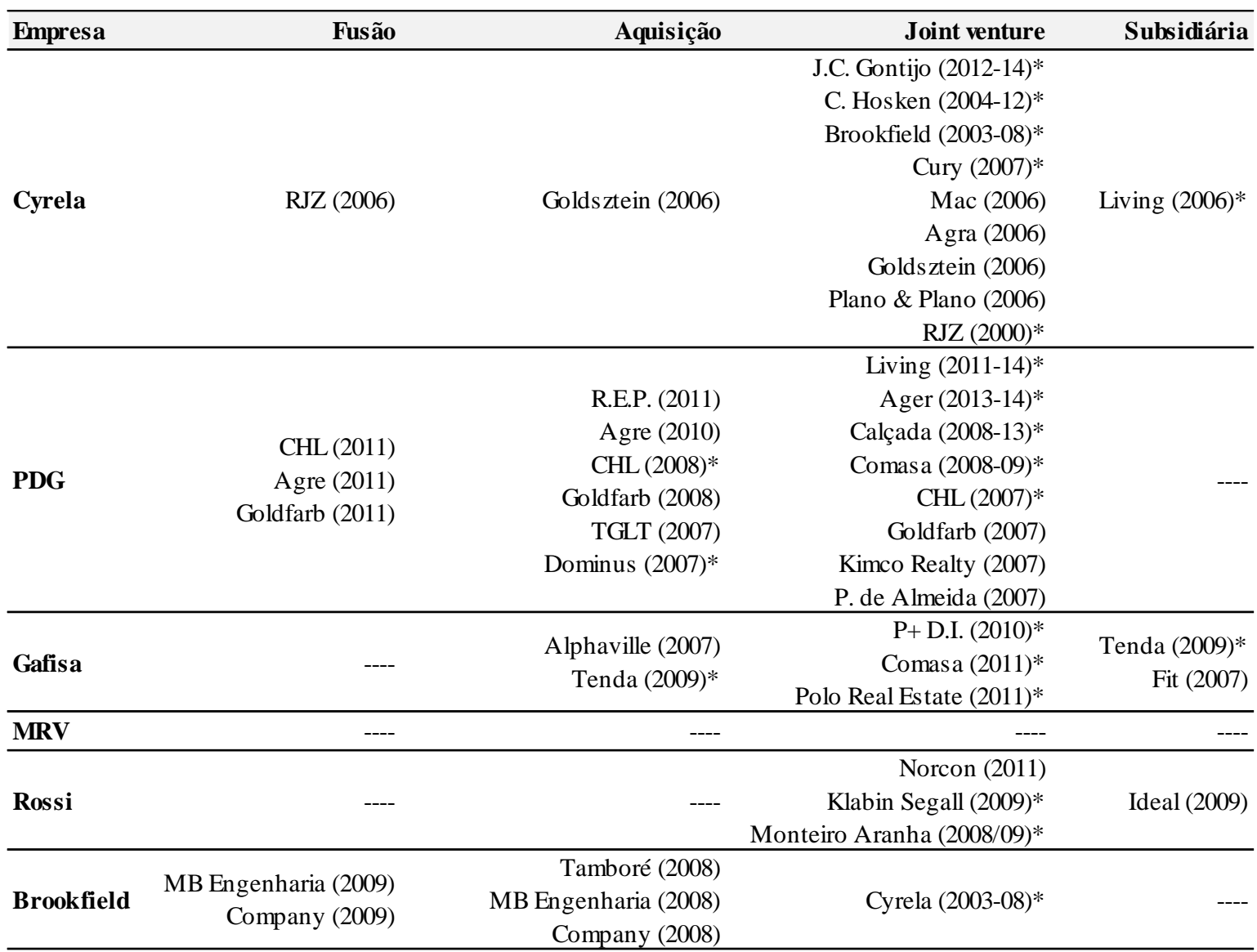

* Atuação no Rio de Janeiro

Fonte: elaboração do autor a partir de dados dos relatórios de resultados das empresas pesquisadas

$\mathrm{Na}$ tabela anterior estão listadas as principais incorporadoras de capital aberto do país mostrando como a expressiva capitalização dessas empresas via mercado financeiro fez com que elas fagocitassem outras empresas do setor, configurando num processo típico de centralização do capital. Esse processo no imobiliário "tende a acontecer de forma tardia" 125 . Nessa reorganização de propriedades dos capitais no setor, as empresas que concentraram capital via mercado financeiro, acabam por expropriar outras empresas menores, fazendo com que a concorrência dentro do setor se torne mais acirrada e esteja num patamar mais elevado, pois a capacidade de produção e de acumulação tornam-se mais intensas. No caso das joint ventures, Lencioni (2017) aponta que no setor imobiliário, muitas empresas se associam para realização de um ou vários empreendimentos imobiliários. "É usual as

${ }^{125}$ RUFINO, 2012, p. 188 
empresas estabelecerem, por meio de um contrato, uma sociedade específica voltada para uma determinada atividade, formando uma SPE - Sociedade de Propósito Específico"126

Para se ter ideia da dimensão dessa expansão geográfica, até mesmo as empresas maiores que já atuavam em mais de um estado, ainda assim, tinham uma atuação em bairros específicos de cada cidade e com um volume de produção bem modesto comparado ao que vieram a produzir após a abertura de capital. A PDG, por exemplo, que em 2006 lançara empreendimentos em apenas três estados brasileiros - São Paulo, Rio de Janeiro e Bahia em 2010 já tinha expandido sua atuação para 17 estados, Distrito Federal e até mesmo para a Argentina. A MRV ainda concentra a maior parte de seu landbank na Região Sudeste, porém o crescimento de aquisição de terrenos em outras regiões do país é notável.

Gráfico 3. Distribuição geográfica dos lançamentos da PDG (2007 e 2011)

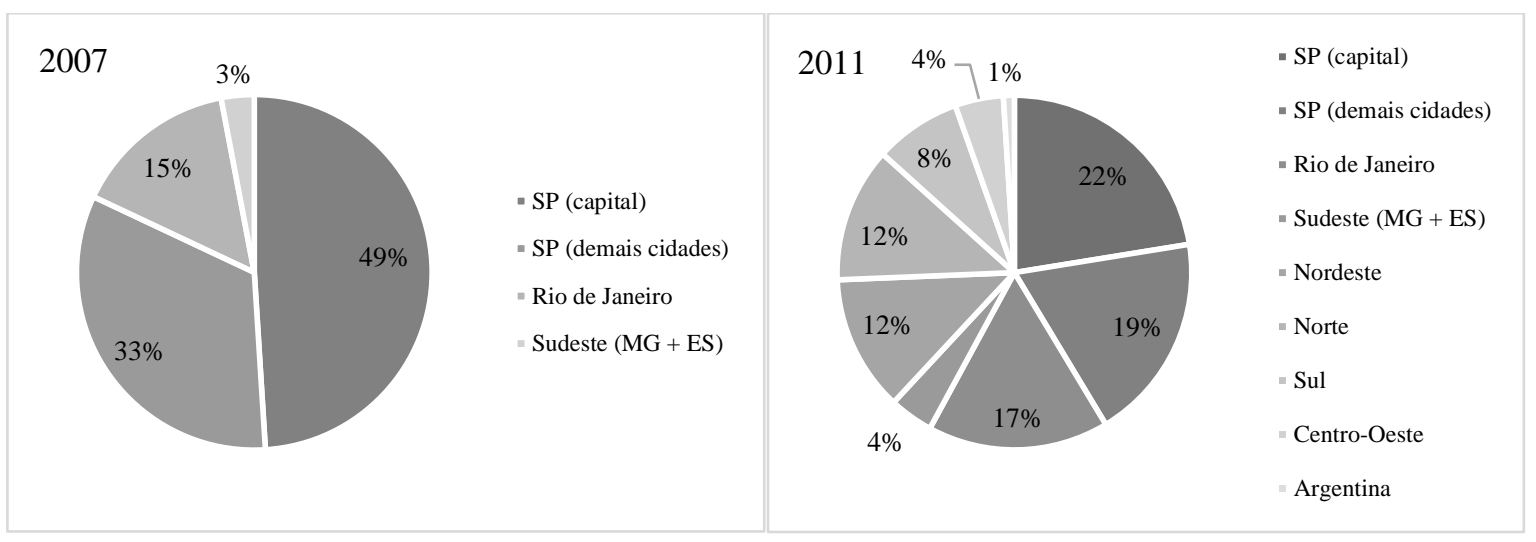

Fonte: elaboração do autor a partir de dados dos relatórios de resultados anuais da PDG

Gráfico 4. Distribuição geográfica do landbank da MRV (2007-2014)

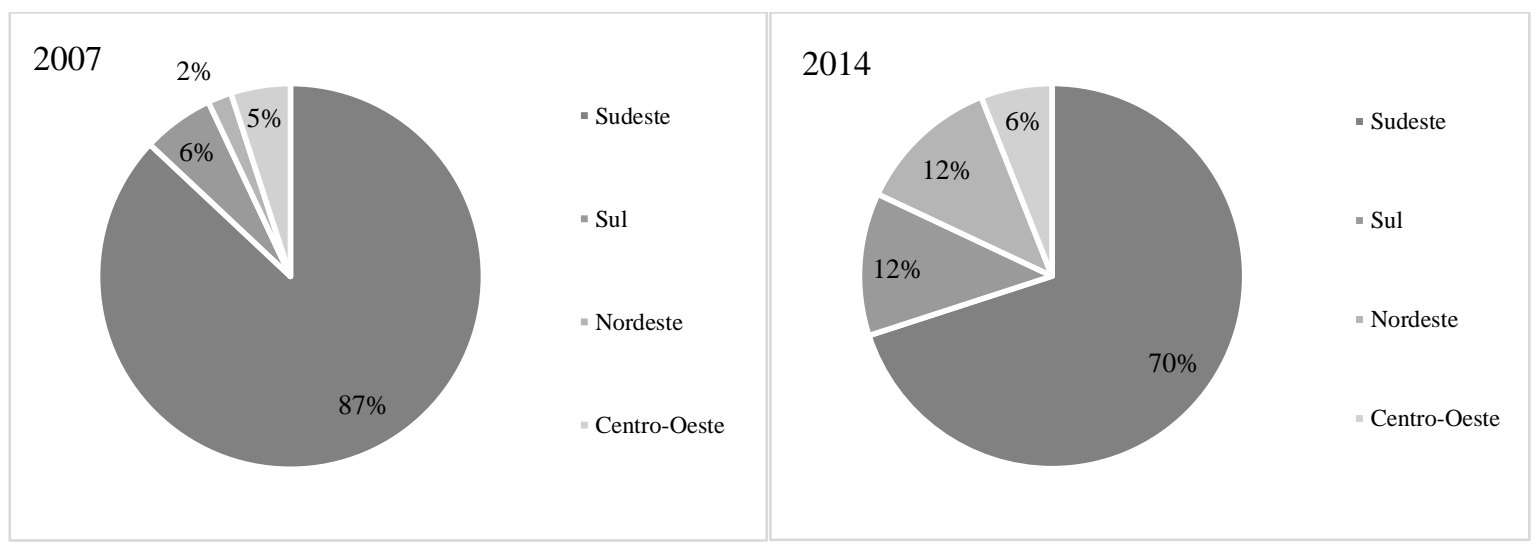

Fonte: elaboração do autor a partir de dados dos relatórios de resultados anuais da MRV

${ }^{126}$ LENCIONI, 2017, p. 121 
A capitalização das incorporadoras via mercado financeiro, desencadeou uma grande disputa entre as empresas pela aquisição de novos terrenos para formação de seus respectivos landbanks. Uma boa parte deste capital absorvido foi imobilizado em terras. A criação dos bancos foi essencial para garantir aos investidores que a produção não apenas não cessaria, mas expandiria. Segundo Santos (2016), os terrenos "passam a figurar como um elo na cadeia da financeirização da produção imobiliária: eles haviam se tornado a ponte de acesso ao mercado de capitais" ${ }^{127}$. De forma geral, as empresas lançaram mão de duas estratégias para obtenção desses terrenos: através da compra direta ou da permuta. No segundo caso, o proprietário do terreno cede o terreno para a incorporadora e esta lhe remunera em unidades habitacionais ao término da produção do empreendimento. Essa corrida pelo incremento dos landbanks pôde ser percebida, num primeiro momento, nas áreas mais valorizadas das grandes metrópoles, em especial no Rio de Janeiro e em São Paulo, onde essas incorporadoras já atuavam. Contudo, os terrenos disponíveis nessas áreas foram ficando cada vez mais escassos e caros, obrigando as empresas a buscarem novas fronteiras de expansão para acumulação.

É a partir desse processo que se desencadeia dois fenômenos imbricados significativos ocorridos na produção do espaço nas cidades brasileiras desde então: a dispersão geográfica da produção habitacional de mercado das grandes incorporadoras nacionais para outros estados brasileiros, conforme já descrito e exposto nos gráficos anteriores, mas também para as periferias urbanas das principais metrópoles brasileiras. Isso pode ser observado com muita clareza na cidade do Rio de Janeiro, onde, a partir de 2007, há uma franca expansão dessa produção para territórios da cidade que até então estavam fora do radar das incorporadoras, sobretudo para Zona Norte e Zona Oeste. Esta última, muito em função dos empreendimentos Faixa 1 do PMCMV.

O outro fenômeno ocorrido foi que essa disputa entre as incorporadoras pela aquisição de terras aumentou o seu preço consideravelmente. Fix (2011) reforça que, “diferentemente de outros ramos econômicos, o aumento na escala nem sempre se traduz na redução do preço unitário dos produtos no caso da construção civil" ${ }^{128}$. Aqui fica evidente, de maneira mais concreta, como o mecanismo de capitalização da terra atua, uma vez que na disputa entre o

\footnotetext{
127 SANTOS, 2016, p. 15
}

${ }^{128}$ FIX, 2011, p. 193 
proprietário da terra e a incorporadora, prevalece o aumento da renda da terra a ser pago para o primeiro, que será auferida no presente, projetando os ganhos no futuro.

O estoque de terrenos funciona como base para a criação de capital fictício,
uma promessa de ganhos futuros antecipando o que poderá ser construído
nos terrenos adquiridos. (...) o monopólio sobre uma parte do território é o
modo que as empresas encontram de garantir aos investidores que serão
capazes de se apropriar de lucro, na construção, e de incrementos de renda
da terra, na incorporação. (FIX, 2011, p. 195)

Esses processos somados deixaram as incorporadoras numa verdadeira sinuca de bico, pois devido à capitalização via mercado financeiro e a necessidade de demonstrar rápidos resultados, era preciso expandir a produção para outras faixas de renda que tradicionalmente não eram atendidas pelo mercado. Ao mesmo tempo, a procura por novos terrenos para realizar essa produção inflacionou seu preço, tornando a produção desses novos empreendimentos mais onerosa, o que dificultaria a aquisição de unidades habitacionais pelas faixas de renda para a qual este mercado agora voltava sua atenção.

Somado a esses processos, é desencadeada entre 2007 e 2008, nos Estados Unidos e em outros países da Europa, uma crise econômica de proporções mundiais que ficou conhecida como a crise dos subprimes. Com o mercado financeiro em profunda crise e instabilidade, há uma fuga de capitais injetados nas incorporadoras brasileiras. As incorporadoras se viram altamente endividadas e com boa parte do seu capital imobilizado em terrenos espalhados por diversas áreas das cidades e metrópoles brasileiras. Os landbanks, até então atrativos, passam a ser um enorme entrave às empresas.

Devido à impossibilidade dos empresários incorporadores, neste contexto, de realizar sua produção, entra em cena então, de maneira mais patente, um dos principais agentes que promoverá as condições gerais para destravar e viabilizar que essa produção se concretize, garantindo, com isso, a reprodução capitalista: o Estado. É (n)ele que (se) impulsiona a dinâmica de valorização do valor.

Na seção seguinte será abordada como se estabeleceu essa relação entre capital e Estado no contexto da produção imobiliária recente brasileira e, mais especificamente, no Rio de Janeiro, abordando as articulações feitas entre as empresas incorporadoras e o governo federal brasileiro que se estendem desde a década de 1990 e também as articulações no âmbito local entre essas mesmas empresas e o governos municipal e estadual no Rio de Janeiro. Dessa maneira, pode-se compreender de forma mais clara como se concretizou a expansão das fronteiras de acumulação capitalista do setor imobiliário a partir da 
reestruturação imobiliária e avanço para o subúrbio carioca. Mas antes, é necessária uma compreensão mais ampla acerca do Estado e os limites de sua conceituação, buscando se afastar de definições simplistas que o encerram dentro de um arcabouço jurídico ou que tratam o Estado como a política do bem comum.

Como já debatido, não dá pra negar que o capitalismo vem se transformando ao longo dos anos, embora ainda se sustente sobre sua estrutura fundante, a saber, a relação capitaltrabalho. À medida que ele avança, as relações sociais engendradas a partir dessas transformações se dinamizam para mantê-lo em funcionamento, ampliando sua reprodução. O Estado que em sua aparência reificada se mostra como um ente neutro, mediador de conflitos sociais e apartado das relações de classe, acompanha essas transformações, uma vez que ele é, em verdade, parte fundamental da reprodução do capital.

O Estado é, antes de tudo, uma relação social. Na sociedade onde as relações sociais são mediadas pela troca de mercadorias, ou seja, capitalistas, o Estado deve ser visto então como uma relação social essencialmente capitalista. Em sua obra, Mascaro (2013) remonta as origens do Estado moderno a partir da teoria marxiana mais madura e reconhece que até o advento do capitalismo nunca foi visto em sociedades anteriores uma forma de organização política estatal como se conhece na atualidade. É somente no capitalismo que o poder econômico se aparta do poder político e os atores que representam cada uma desses poderes se distinguem, pelo menos em teoria. Segundo o autor, "para entendimento do Estado e da política, é necessário o entendimento de sua posição relacional, estrutural, histórica, dinâmica e contraditória dentro da totalidade da reprodução social". Portanto, a compreensão dos contornos desse Estado "só pode se fundar na crítica da economia política capitalista, lastreada necessariamente na totalidade social" ${ }^{129}$.

O Estado se exibe então enquanto um fenômeno especificamente capitalista. Desse modo, "não se pode buscar suas respostas, a princípio, na política, mas sim no capitalismo. (...) A troca de mercadorias é a chave para desvendar essa especificidade" ${ }^{130}$. É ele que vai garantir a partir de sua forma política e arcabouço jurídico, engendrados no seio do modo de produção capitalista, as condições gerais de reprodução do capital e assegurar a troca das mercadorias,

\footnotetext{
${ }^{129}$ MASCARO, pp. 11-14

${ }^{130}$ Ibid., p. 18
} 
ou seja, a instituição das relações sociais capitalistas. Ao mesmo tempo, esse mesmo Estado aparece como um "terceiro" na dinâmica entre capital e trabalho, não como um corpo estranho à essa relação, mas como parte essencial que assegura a conformação dessa relação.

Daí a dificuldade em se aperceber, à primeira vista, a conexão entre capitalismo e Estado, na medida em que, sendo um aparato terceiro em relação à exploração, o Estado não é nenhum burguês em específico nem está em sua função imediata. A separação em face de todas as classes e indivíduos constitui uma chave da possibilidade da própria reprodução do capital: o aparato estatal é a garantia da mercadoria, da propriedade privada e dos vínculos jurídicos de exploração que jungem o capital e o trabalho (MASCARO, 2013, p.18, grifo nosso)

No campo da produção do espaço, a instituição e garantia da propriedade privada da terra é central para a reprodução capitalista. Nesse sentido, o Estado atua na formulação de formas jurídicas que perpetue essa forma de propriedade e, somado a isso, garanta também maior dinamismo e segurança na transação desta propriedade como mercadoria a partir de instrumentos e mecanismos instituídos por lei que visem sua maior liquidez.

Partindo também de uma abordagem materialista e histórica para abordar o Estado moderno, Harvey (2005) aponta, ainda no campo da produção do espaço, outro papel desempenhado pelo Estado para assegurar a reprodução capitalista a partir do espaço. Segundo o autor, o Estado possui “um papel importante no provimento de 'bens públicos' e infraestruturas sociais e físicas; pré-requisitos necessários para a produção e troca capitalista, mas os quais nenhum capitalista individual acharia possível prover com lucro" ${ }^{\prime 31}$.

É a partir desse entendimento acerca do Estado que será discutido mais detalhadamente as articulações empreendidas com o capital incorporador no contexto brasileiro em suas diferentes esferas a partir de relações já estabelecidas na década de 1990 com a criação de novos instrumentos financeiros-imobiliários já num contexto de neoliberalização, mas, sobretudo, a partir de meados da década de 2000 com o boom imobiliário ocorridos nas cidades brasileiras, tendo como referência as transformações ocorridas no Rio de Janeiro e, particularmente, no subúrbio carioca.

${ }^{131}$ HARVEY, 2005, p. 85 


\subsection{A constituição de mecanismos jurídico-financeiros e imobiliários de capitalização no âmbito nacional}

\section{Criação e sofisticação de instrumentos financeiros imobiliários}

É inegável que a abertura de capital das grandes incorporadoras explica, em grande parte, a expansão da produção imobiliária no Brasil a partir de 2007. Porém, esta se tornou a face mais visível de todo esse processo. Outros fatores colaboraram decisivamente para que todo um ambiente favorável fosse estabelecido e respaldasse o exitoso processo de abertura de capital das principais empresas do setor. A atuação do Estado na esfera federal que, por um lado, vem aperfeiçoando o ambiente regulatório desde a década de 1990, proporcionando maior segurança jurídica aos agentes envolvidos - sobretudo no que diz respeito à propriedade - e mecanismos que aceleram a liquidez da mercadoria imóvel como ativo financeiro, foram fundamentais para que a engrenagem do sistema pudesse funcionar. Por outro lado, na esfera do consumo, facilitou o acesso ao crédito para o usuário final, com alterações nas taxas de juros, alargamento do prazo de financiamento e flexibilização do percentual financiável.

Como já mencionado, esse processo se inicia na década de 1990, cujo cenário é marcado pela inserção ativa das economias latino-americanas no neoliberalismo. É neste período que uma série de políticas macroeconômicas são realizadas seguindo a cartilha neoliberal instituídas há pouco mais de uma década antes pelos governos estadunidense e inglês, fortalecendo amplamente o capital financeiro. Embora o discurso hegemônico neoliberal revele em sua aparência uma militância em prol da retirada do Estado da economia, o que se esconde por trás dessa retórica é justamente a captura do Estado para um modo específico de atuação na economia. De forma bem sucinta, pode-se citar a influência decisiva do Fundo Monetário Internacional (FMI), os mecanismos de garantia de estabilidade cambial, altas taxas de juros e uma abertura cada vez maior das economias nacionais para circulação de capitais estrangeiros. Segundo Royer (2009),

\footnotetext{
As profundas transformações do padrão de acumulação capitalista nas últimas décadas e a disseminação das finanças como matriz de organização da riqueza em escala mundial impuseram uma nova racionalidade ao desenho institucional das políticas públicas, tanto nos países do centro quanto nos países subdesenvolvidos (ROYER, 2009, p.13)
}

Nesse contexto, as políticas de Estado passam a atuar no sentido de facilitar a entrada de capital financeiro nas economias nacionais, transformando e atingindo todos os ramos da economia e, como não poderia deixar de ser, também atingiram o setor imobiliário brasileiro 
que, através do lobby de seus representantes, buscaram instituir um modelo de captação de recursos privados através do mercado financeiro após o fim do Banco Nacional de Habitação $(\mathrm{BNH})$ e, consequentemente dos financiamentos oriundos dele. Fato este que acarretou num longo período, entre as décadas de 1980 e 1990, de estagnação do setor. Com isso, os primeiros mecanismos de financiamento via mercado privado apareceram no início da década de 1990. No ano de 1993 foi instituída a Lei n 8.668 que criou os Fundos de Investimento Imobiliário (FII), caracterizado pela comunhão de recursos captados e destinados à aplicação em empreendimentos de natureza exclusivamente imobiliária, sob regulação da Comissão de Valores Mobiliários (CVM). Segundo Fix (2011),

\begin{abstract}
A vantagem dos FII do ponto de vista do circuito imobiliário é que os fundos permitem reunir recursos para investimentos, sem fragmentar a propriedade do imóvel. Algo particularmente vantajoso para torres de escritório que, no padrão anterior, exigiam a reunião de um número grande de investidores, que repartiriam as salas ou andares do edifício. A criação de um FII permite que cada um deles se torne proprietário de certo número de cotas. Ainda para o setor imobiliário, isso permitia atrair investidores que não tinham necessariamente interesse em utilizar o imóvel. (FIX, 2011, p. 126)
\end{abstract}

Com o objetivo de captar recursos privados via mercado financeiro, em 1997 é instituído o Sistema de Financiamento Imobiliário (SFI) através da Lei no 9.514. Segundo o texto legal, a captação desses recursos se realiza por meio da securitização de títulos e, como garantia para que as transações ocorressem de maneira segura, o Sistema também institui o instrumento da alienação fiduciária, visando maior eficiência no resgate da propriedade caso o pagamento do financiamento seja interrompido, como indica Royer (2009). O SFI buscou então se aproximar do modus operandi do mercado financeiro e, com isso, garantir um ambiente seguro e rentável de negócios para investidores sem intermediação do Estado, seguindo os predicados neoliberais em voga. Dessa forma, o SFI lançou mão de um novo instrumento financeiro, o Certificado de Recebíveis Imobiliários (CRI), que se configura pelo texto da lei como um título de crédito nominativo, de livre negociação, lastreado em créditos imobiliários e que constitui promessa de pagamento em dinheiro. A autora ainda assinala que

no Brasil, em especial, a montagem do SFI teve como justificativa a necessidade de construção de padrões alternativos para o financiamento das políticas públicas, informadas pelas severas restrições da política fiscal e pelos limites do endividamento externo. Assim, (...) a conjuntura histórica direcionava os esforços da política econômica para as reformas institucionais predicadas pelo discurso da 'austeridade fiscal' permanente (ROYER, 2009, p.15) 
No contexto brasileiro, "Os mecanismos em funcionamento, como Fundos de Investimento Imobiliário (FII) e Certificados de Recebíveis Imobiliários (CRI), entre outros, têm alcance restrito no segmento residencial" 132 . Diante desse cenário, o instrumento da alienação fiduciária foi "considerado pelo mercado de crédito imobiliário o mais inovador"133, pois garantia a sustentabilidade jurídica desejada pelos agentes financeiros em suas transações, colocando em xeque a "lenta execução das operações feitas com hipoteca no Brasil, especialmente na sua execução judicial"134. Esse instrumento foi crucial para garantir um ambiente mais favorável para o aporte de capital via mercado financeiro no setor, pois no caso da hipoteca

\begin{abstract}
é transferido o direito de posse e o domínio ao mutuário. Mesmo este tendo pago apenas 20 ou $30 \%$ do valor total do financiamento, o tomador do empréstimo já tem a posse e o domínio, ainda que esse domínio seja entregue ao agente financeiro. Na alienação transfere-se apenas a posse $e$ não o domínio. O domínio só é transferido com a liquidação da dívida. (...) A alienação fiduciária, sendo considerada uma garantia real do bem que está sendo adquirido, transfere para o banco a propriedade do imóvel, tendo o mutuário somente a posse e não a propriedade" (ROYER, 2009, p.115, grifos nosso)
\end{abstract}

Nessa perspectiva, Rufino (2012) aponta que essa primeira aproximação entre capital financeiro e o setor imobiliário no Brasil traz à tona outros agentes que não apenas as incorporadoras e construtoras como os "fundos de pensão, fundos de investimentos, companhias securitizadoras e fundos ligados a grandes corporações" ${ }^{135}$. Outra característica importante a ser ressaltada é que a instituição desses instrumentos potencializa a propriedade imobiliária como ativo financeiro, uma vez que transforma esta mercadoria num "papel" dotado de maior liquidez quando transacionado via mercado de ações. Botelho (2005) sugere que esses instrumentos engendram um fenômeno novo que o autor denomina como desabsolutização da propriedade imobiliária, uma vez que a já consagrada propriedade privada absoluta, baseada num registro de título legal, passa a ser "substituída por uma propriedade parcelar de um bem imobiliário, que dá direito à extração de uma renda e de juros sobre a propriedade, mas não sobre o ativo em si"136.

Contudo, devido à instabilidade macroeconômica no Brasil dos anos 1990, o SFI não se consolidou enquanto uma alternativa via mercado de captação de recursos para garantir a

\footnotetext{
${ }^{132}$ FIX, 2011, p. 136

${ }^{133}$ Ibid., p. 115

${ }^{134}$ Ibid., p. 115

135 RUFINO, 2012, p. 66

${ }^{136}$ BOTELHO, 2005, p. 155
} 
retomada da produção imobiliária, mesmo que tenha sido considerado um importante avanço pelos agentes do mercado. Royer (2009) também aponta que a elevada taxa de juros praticada no país à época foi o principal entrave para o desenvolvimento do SFI. Além disso havia, por parte do setor, uma crítica a alguns pontos considerados um obstáculo ao pleno desenvolvimento do Sistema, como a ausência de legislação que garantisse "o pleno cumprimento das leis, normas operacionais e contratos, que pudessem enquadrar o risco jurídico como mínimo e previamente mensurável, especialmente no caso da retomada das garantias reais"137. Paralelamente a essas críticas, o setor imobiliário também pleiteava desonerações tributárias até então não previstas no SFI.

Já na década de 2000, com o favorecimento da conjuntura macroeconômica internacional e estabilidade monetária, é instituído no ano de 2004 uma nova lei com objetivo de reforçar o avanço da financeirização no setor imobiliário e calibrar alguns aspectos que ainda tornava truncado o pleno funcionamento do SFI. Trata-se da Lei $n^{\circ} 10.931$, comumente chamada por Lei do Patrimônio de Afetação, que dispõe também sobre outros instrumentos, como o Valor do Incontroverso e uma atualização da Alienação Fiduciária. Esta lei veio para consolidar “a base legal do setor imobiliário-financeiro e reforçou as garantias a financiadores e compradores, reforçando o arcabouço jurídico necessário à expansão do setor imobiliário no modelo do SFI"138. A instituição do instrumento Patrimônio de Afetação "segrega os ativos de um empreendimento dos outros ativos da empresa promotora, de forma que os recursos financeiros de um determinado empreendimento ficam apartados do resto dos ativos da empresa construtora e incorporadora" ${ }^{139}$, o que dá maior segurança ao consumidor final caso a empresa venha a decretar falência. Rufino (2012) ainda esclarece que, "ao adotarem este regime de afetação, os incorporadores beneficiam-se ainda de uma tributação especial, com alíquota única de 7\%"140.

Ainda no âmbito desta lei, o Artigo 50 , que dispõe sobre o Valor do Incontroverso, garante que, no caso de contratos que estejam sub judice, o comprador continue arcando com as despesas das parcelas até que a disputa judicial esteja resolvida. "Trata-se de suspensão de pagamento do financiamento imobiliário restrito ao que está sendo questionado

\footnotetext{
${ }^{137}$ ROYER, 2009, p. 117

${ }^{138}$ Ibid., p. 118

${ }^{139}$ Ibid., p. 118

${ }^{140}$ RUFINO, 2012, p. 56
} 
judicialmente e não em relação a todo o contrato. Buscou-se acabar com a chamada 'indústria das liminares"”141.

Além disso, outros títulos foram adicionados ao escopo da lei com intuito de facilitar as negociações entre as partes, dar maior autonomia para as instituições financeiras e reduzir custos na emissão de títulos de crédito no mercado como as Cédulas de Crédito Imobiliário (CCI), Letras de Crédito Imobiliário (LCI) e as Cédulas de Crédito Bancário (CCB). De acordo com Shimbo (2012), esse conjunto de instrumentos financeiros significavam, na verdade, uma estratégia requerida pelos agentes de mercado "para garantir a realização da rentabilidade do capital emprestado, como para pressionar o setor à financeirização, através da necessidade crescente de adoção de instrumentos de captação externa de recursos para a incorporação e construção imobiliária" ${ }^{142}$.

Para além dos instrumentos financeiros acima citados, um outro fator foi de extrema importância para impulsionar o boom imobiliário que se observou a partir de 2007. Enquanto a instituição legal de instrumentos financeiros buscou beneficiar os agentes de produção e investidores com a criação de mecanismos que dinamizassem as operações, garantissem a acumulação e dessem segurança jurídica aos negócios, por outro lado, a facilitação e flexibilização do crédito e das formas de financiamento ao consumidor final era a peça que faltava para garantir a expansão pois, como já discutido anteriormente, uma as características que tornam particulares a mercadoria habitação é o seu alto preço, não sendo possível para a maior parte da sociedade a sua integral aquisição de imediato. Com relação ao sucesso desse tipo de subsídio ao consumo, Shimbo (2012) atribui

\footnotetext{
à melhoria do crédito para pessoa física a partir da redução das taxas de juros, do aumento dos prazos de pagamento (até 30 anos) e da diminuição nos valores de entrada (necessidade de menor poupança prévia) - além da ampliação da quota de financiamento de imóveis (para imóveis usados, por exemplo, de $70 \%$ do valor total do imóvel passível de ser financiado passou-se para 90\%). (...) Essas melhorias no crédito também se devem à queda da taxa de juros da economia, reforçando a repercussão do contexto macroeconômico do país na situação do financiamento habitacional" (SHIMBO, 2012, p.53)
}

Por fim, o que é importante sublinhar é que, apesar de todos os instrumentos citados que foram instituídos e colocados em prática terem sido importantes, pode-se dizer que o que configura a particular financeirização ocorrida no setor imobiliário brasileiro é a captura dos

\footnotetext{
${ }^{141}$ ROYER, 2009, p. 118

142 SHIMBO, 2012, p. 62
} 
fundos paraestatais vinculados ao SFH - o Fundo de Garantia do Tempo de Serviço (FGTS) e o Sistema Brasileiro de Poupança e Empréstimo (SBPE) - para financiamento dessa produção, uma vez que a garantia e segurança que esses fundos davam aos investimentos era o que os tornava atrativos. Como esclarece Rufino (2012),

contrariando o discurso difundido pelas entidades representativas do setor imobiliário de falência do Estado e de necessidade de se buscar novas fontes de financiamento, as tradicionais fontes de financiamento imobiliário no Brasil (SBPE e FGTS) começam a apresentar resultados excepcionais a partir de 2005, configurando-se como a grande base para a expansão do setor. Entre 2005 e 2010, a contratação de recursos para a habitação a partir da utilização do FGTS foi multiplicado em cerca de cinco vezes, sendo este aumento ainda mais expressivo no caso do SBPE, onde os volumes contratados em 2010 superam em mais de dez vezes as contrações do ano de 2005 (RUFINO, 2012, pp.58-59)

Através da instituição do CRI, uma parte dos recursos oriundos do SBPE e do FGTS passaram a ser objetos de disputa, "a partir de uma série de resoluções dos conselhos responsáveis pelo SBPE (CMN) e pelo FGTS (CCFGTS), que foram editadas praticamente ano a ano desde 1998"143. Tais resoluções propiciavam para a difusão dos CRI's já que permitia a aquisição desses títulos em financiamentos para empreendimentos imobiliários, no caso do FGTS que, em tese, deveria destinar recursos para a provisão habitacional de uma demanda não solvente, além de facilitar a captação de recursos do SBPE com um custo muito baixo.

Em síntese, como conclui Fix (2011), "no lugar de fontes novas, prometidas pelo SFI, capturam-se recursos dos dois fundos que eram a base do BNH e que continuam sendo primordiais para a política habitacional" ${ }^{144}$. Essa contradição que marca a financeirização do imobiliário no Brasil se sustenta, de um lado, por meio de um discurso ideológico de inoperância do Estado e de resolução da problemática habitacional pela via do mercado como saída única e, por outro, pela dependência de fundos geridos pelo próprio Estado em prol da facilitação da entrada de investimentos financeiros.

O modelo de financiamento, lastreado na captação de recursos pelos mercados de capitais, seja nos mercados primários, seja nos mercados secundários, não prescinde do fundo público, como pode parecer à primeira vista. Praticamente não há experiência no mundo, em especial na periferia do capitalismo, de uma captação de recursos que não tenha contado com o apoio dos fundos estatais, seja pelo aporte direto de recursos orçamentários, seja pela concessão de garantias, seja pela concessão de isenções e vantagens tributárias que garantem competitividade aos fundos de investimento. O próprio Banco Mundial, sempre um militante do

\footnotetext{
143 RUFINO, 2012, p. 55
}

${ }^{144}$ FIX, 2011, p. 132 
protagonismo do mercado, é um defensor da participação ativa do Estado na criação das condições efetivas para o desenvolvimento do financiamento imobiliário. Assim, mesmo os mais sofisticados sistemas de crédito tendem a depender do Estado para impulsionar a acumulação de capital (ROYER, 2009, pp.26-27)

Nessa lógica, o Estado se faz ativamente presente mobilizando financiamentos, subsídios, institucionalização de instrumentos, além de outras políticas pautadas em padrões internacionais, para criar as condições gerais de acumulação a partir do imobiliário no Brasil.

\section{Programa Minha Casa Minha Vida}

Como mencionado anteriormente, o ano de 2008 é marcado por uma profunda crise financeira internacional que ficou conhecida como a crise dos subprimes, que se originou nos Estados Unidos e rapidamente afetou várias economias pelo fundo, principalmente nos países da Europa.

A fuga de capitais em consequência dessa crise atingiu em cheio as grandes incorporadoras do setor imobiliário brasileiro que poucos anos antes abrira seu capital na Bolsa de Valores. Essas empresas haviam imobilizado grande parte dos recursos financeiros oriundos das ofertas de suas ações em terrenos para construção de novos empreendimentos e, com a retirada desses recursos durante a crise se viram altamente endividadas e com um vasto estoque de terrenos inerte.

Como forma de reagir à inevitável crise que chegaria com força ao Brasil, o governo federal lança um pacote de medidas anticíclicas para estimular a economia. É a partir disso que em 2009 foi lançado o Programa Minha Casa Minha Vida como uma dessas políticas, algo que há alguns anos - vale mencionar - já era pleiteado pelas associações e sindicatos da indústria da construção civil e incorporadoras através de lobby junto ao governo federal. O Programa, além de resgatar a saúde financeira das incorporadoras, conseguiria, em pouco tempo, mobilizar uma grande quantidade de novos postos de trabalho na construção civil. Historicamente no Brasil, o setor da construção foi a saída encontrada como medida anticíclica em momentos de crise e de retomada da economia, uma vez que a baixa composição orgânica do capital do setor permite empregar uma grande quantidade de trabalhadores a baixos salários.

Com isso, o PMCMV conseguiu aliar, ao menos no discurso, duas questões urgentes no contexto brasileiro. De um lado, o histórico quadro de déficit habitacional merecia atenção, 
sobretudo porque quem ocupava o poder político do país à época era justamente o partido político forjado, décadas antes, no cerne das lutas populares urbanas que tinha como uma das principais bandeiras o direito à moradia. De outro lado, a crise mundial demandava do governo brasileiro um programa econômico de rápida reação. Nesse sentido, o desenho do PMCMV contou com a participação dos ministérios da Casa Civil e Fazenda e da Caixa Econômica Federal (CEF) em conjunto com entidades representativas do setor imobiliário e construção civil, como a Câmara Brasileira da Indústria da Construção (CBIC) e os Sindicatos das Empresas de Compra, Venda, Locação e Administração de Imóveis Residenciais e Comerciais (SECOVIs). O Ministério das Cidades que, desde sua criação, vinha desenvolvendo um trabalho meticuloso em relação ao combate do déficit habitacional, levando em consideração a sua complexidade e a diversidade regional, teve uma participação coadjuvante nesse processo, o que reforça a ideia de que a instituição do PMCMV tinha um caráter prioritariamente econômico e que o enfrentamento do déficit habitacional fora apenas um pretexto. A partir disso, o Programa foi lançado como Medida Provisória (MPv 459) em 2009, alcançando o status de Lei ( $\left.n^{\circ} 11.977\right)$ no mesmo ano.

Em linhas gerais, o desenho da primeira fase do Programa, iniciada em 2009 e finalizada em 2011, previu a construção de 1 milhão de unidades habitacionais, divididos em três faixas de renda através do aporte de R \$ 34 milhões oriundos da União e do FGTS. A Faixa 1 foi destinada a famílias com renda até três salários mínimos. Nessa faixa, o subsídio era quase integral garantidos com recursos da União através de subvenção. As operações eram garantidas pelo Fundo de Arrendamento Residencial (FAR) e poderia ser acionado pelas prefeituras e construtoras, desde que a operação fosse aprovada pela CEF para a liberação dos recursos. As Faixas 2 e 3 do programa se diferenciavam basicamente nas faixas de renda: 3 a 6 salários mínimos e 6 a 10 salários mínimos, respectivamente. Nessas faixas os recursos eram oriundos do FGTS, o que exigia retorno com pagamento de juros, ainda que abaixo dos praticados pelo mercado. A Fase 2 do programa, que durou de 2011 a 2014, alterou alguns pontos da primeira fase: foram previstos o dobro da quantidade de unidades habitacionais a serem construídas em relação à Fase 1 e a Faixa 1 passou a corresponder $60 \%$ (na Fase 1 foram apenas 40\%) do total de unidades. Ademais, os limites das faixas de renda foram atualizados.

Após esse breve panorama do Programa, pode-se dizer que, dentro do campo dos estudos urbanos, muitas foram as pesquisas que se dedicaram a observar o PMCMV sob diversas 
perspectivas teóricas e eixos analíticos. No contexto do atual trabalho, lançaremos luz sobre um ponto que se considera importante para compreensão deste trabalho: a relação entre os agentes imobiliários e o Estado na formulação do Programa e como a lógica financeira que o permeia refletiu na produção do espaço.

Ao contrário do que acontecia no período do $\mathrm{BNH}$, onde o Estado atuava como um agente na promoção e gerenciamento dos projetos, funcionando como um elo entre a fonte de recursos e as construtoras, o desenho institucional do PMCMV prescinde dessa figura. Como aponta Rufino (2015), “A instituição financeira (Caixa Econômica Federal), por um lado, e as empresas, por outro lado, ganham centralidade em detrimento dos órgãos e instituições responsáveis pelas políticas urbanas e habitacionais" ${ }^{\text {145 }}$. O Programa tem como característica central uma política de crédito imobiliário, onde a Caixa exerce a função de credora direta das incorporadoras. Estas, por sua vez, ficam responsáveis pela viabilidade do empreendimento e passam a produzir o urbano a partir de suas próprias estratégias, num contexto onde a gestão territorial, tradicionalmente dirigida pelo Estado, perde relevância. Na realidade, o que se observou neste período foi justamente a inversão desses papéis, onde os poderes locais se subjugam às estratégias de acumulação das incorporadoras, adequando e flexibilizando suas leis urbanísticas para receber esses novos empreendimentos.

\footnotetext{
O reforço de uma lógica financeira está pautado em grande medida pelo papel das empresas de construção no Programa, que passam a atuar como proponentes de empreendimentos junto à Caixa, seguindo as normas e condições mínimas estabelecidas. Dentro dessa racionalidade, conduzida pelas empresas, a escolha dos terrenos e as características dos projetos são condições essenciais para "viabilizar" os empreendimentos. A seleção de terrenos mais baratos, a ampliação da escala e padronização dos projetos tornam-se assim estratégias financeiras essenciais no desenvolvimento do PMCMV. Essas estratégias são ainda mais evidentes nas grandes empresas (RUFINO, 2015, pp. 55-56).
}

A questão da terra, como não poderia deixar de ser, torna-se central para viabilidade dos empreendimentos do PMCMV, uma vez que o grande volume de recursos promovidos pelo programa engendra uma disputa entre as incorporadoras, impulsionando "a expansão do mercado de terras em muitas cidades, ampliando a concorrência em torno de terrenos que antes eram tidos como 'fora' do mercado formal de habitações"146. A partir dessa concorrência, o que se constata é o expressivo aumento do preço da terra nas cidades brasileiras. Com isso, se acirram as contradições onde o próprio programa que tinha como

\footnotetext{
145 RUFINO, 2015, p. 55

${ }^{146}$ Ibid., p. 59
} 
um dos objetivos primordiais a redução do déficit habitacional a partir da disponibilidade de crédito para a produção e o consumo, contribui para a criação do obstáculo que impossibilita a redução do mesmo. Por outro lado, ampliam-se os ganhos decorrentes da capitalização da propriedade da terra, confirmando o entendimento inicial de que o PMCMV foi, antes de tudo, um programa econômico que viabilizou as condições de gerais de acumulação financeira num período marcado pela expansão do setor no Brasil.

\subsection{A constituição de mecanismos socioespaciais de capitalização no âmbito local}

\section{O PMCMV no Rio de Janeiro}

Poucos meses após o lançamento do PMCMV no cenário nacional, o município do Rio de Janeiro aderiu ao programa a partir da instituição da Lei Complementar 97/2009. Essa LC dispõe de normas especiais para implantação dos empreendimentos associados ao programa, prevalecendo sobre a legislação local vigente. A meta estipulada pela prefeitura à época era de amplo atendimento às famílias enquadradas na Faixa 1 do programa. Grupo este que representava cerca de $90 \%$ do déficit habitacional da cidade. Contudo, o que a primeira vista podia parecer uma forma assertiva de mitigar o déficit, tornou-se um expediente de reassentamento de famílias forçadamente removidas de áreas (comunidades, favelas e ocupações) que estavam no radar do governo municipal e das grandes incorporadoras para realização de obras de infraestrutura, equipamentos públicos e instalações que serviriam aos Jogos Olímpicos realizados em 2016 na cidade, como também para lançamento de novos empreendimentos imobiliários. Cardoso (2015) aponta que,

\footnotetext{
segundo uma representante da Caixa, apesar do limite máximo de 50\% para unidades habitacionais destinadas a situações em que a escolha das famílias foi dispensada de sorteio, o município do Rio de Janeiro já teria utilizado "quase 90\%" em termos de unidades para situações de reassentamento, com a perspectiva de apenas em algum momento no futuro adequar tais percentuais à norma atribuída (CARDOSO et al, 2015, pp. 77-78)
}

Além da flexibilização de normas urbanísticas para empreendimentos do PMCMV, a prefeitura do Rio também legislou acerca de concessões de incentivos fiscais para as construções e construtoras, doou terrenos para implementação de empreendimentos Faixa 1, bem como agilizou o licenciamento de obras a partir da instituição de comissão especial voltada exclusivamente para aprovação de projetos vinculados ao programa. 
Desde o início da adesão da prefeitura do Rio ao programa, fazendo dele o seu exclusivo programa habitacional, os números de empreendimentos vinculados ao PMCMV foram bem representativos e figuravam em diversos bairros da cidade. Entre 2009 e 2015, foram licenciadas mais de 5 milhões de $\mathrm{m}^{2}$ (26,3\% da área residencial licenciada), totalizando cerca de 93 mil unidades (44,4\% do número de unidades residenciais licenciadas) entre as 3 faixas do programa. As tabelas a seguir mostram que nos dois primeiros anos, as unidades licenciadas vinculadas ao programa foram extremamente significativas. Em 2010, cerca de $70 \%$ de todas as unidades residenciais licenciadas na cidade estavam vinculadas ao PMCMV.

A partir de 2010, esses números tem uma queda significativa, embora a quantidade de unidades licenciadas vinculadas ao programa tenha ainda uma participação relevante no montante total. Tal fato pode ser explicado pela diversificação dos lançamentos das grandes incorporadoras que atuam na cidade e que possuem expressiva participação no programa, bem como pela imposição de restrições por parte da prefeitura quanto à livre implantação de empreendimentos na AP 5, uma vez que é a área da cidade menos assistida do ponto de vista de infraestruturas de mobilidade e saneamento básico, bem como de equipamentos públicos.

Tabela 3. Áreas licenciadas no município do Rio de Janeiro (2009-2015)

\begin{tabular}{lrrrrr}
\hline \multirow{2}{*}{ Ano } & \multicolumn{2}{c}{ Área } & \multicolumn{2}{c}{ Participação do MCMVna área } \\
& Total $\left(\mathrm{m}^{2}\right)$ & Residencial $\left(\mathrm{m}^{2}\right)$ & MCMV $\left(\mathrm{m}^{2}\right)$ & Total $(\%)$ & Residencial $(\%)$ \\
\hline 2009 & 5.065 .207 & 3.355 .090 & 1.071 .330 & 21,2 & 31,9 \\
2010 & 4.900 .829 & 3.048 .676 & 1.528 .358 & 31,2 & 50,1 \\
2011 & 5.302 .692 & 2.512 .811 & 683.510 & 12,9 & 27,2 \\
2012 & 5.192 .019 & 3.128 .806 & 269.122 & 5,2 & 8,6 \\
2013 & 5.951 .075 & 3.033 .175 & 485.597 & 8,2 & 16,0 \\
2014 & 4.399 .796 & 2.317 .850 & 523.959 & 11,9 & 22,6 \\
2015 & 3.670 .401 & 1.656 .996 & 457.049 & 12,5 & 27,6 \\
Total & $\mathbf{3 4 . 4 8 2 . 0 1 9}$ & $\mathbf{1 9 . 0 5 3 . 4 0 4}$ & $\mathbf{5 . 0 1 8 . 9 2 5}$ & $\mathbf{1 4 , 6}$ & $\mathbf{2 6 , 3}$ \\
\hline
\end{tabular}

Fonte: Secretaria Municipal de Urbanismo 
Tabela 4. Número de unid. licenciadas no município do Rio de Janeiro (2009-2015)

\begin{tabular}{lrrrrr}
\hline \multicolumn{1}{c}{ Ano } & \multicolumn{2}{c}{ Unidades } & \multicolumn{3}{c}{$\begin{array}{c}\text { Participação do MCMVno } \\
\text { número de unidades }\end{array}$} \\
& \multicolumn{1}{c}{ Total } & Residencial & MCMV & \multicolumn{1}{c}{ Total (\%) } & Residencial (\%) \\
\hline 2009 & 42.583 & 38.056 & 19.996 & 47,0 & 52,5 \\
2010 & 45.430 & 40.683 & 28.611 & 63,0 & 70,3 \\
2011 & 39.874 & 26.593 & 12.476 & 31,3 & 46,9 \\
2012 & 34.875 & 26.180 & 4.920 & 14,1 & 18,8 \\
2013 & 38.834 & 31.726 & 9.193 & 23,7 & 29,0 \\
2014 & 33.264 & 27.310 & 10.209 & 30,7 & 37,4 \\
2015 & 21.618 & 18.607 & 7.536 & 34,9 & 40,5 \\
Total & $\mathbf{2 5 6 . 4 7 8}$ & $\mathbf{2 0 9 . 1 5 5}$ & $\mathbf{9 2 . 9 4 1}$ & $\mathbf{3 6 , 2}$ & $\mathbf{4 4 , 4}$ \\
\hline
\end{tabular}

Fonte: Secretaria Municipal de Urbanismo

A distribuição dos empreendimentos do PMCMV pela cidade de acordo com as Áreas de Planejamento não guarda uma proporção equilibrada. Os empreendimentos também possuem características muito particulares de acordo com cada AP, seja em relação ao enquadramento das faixas, tipologias e até mesmo no que diz respeito a seus portes. A AP 5, por exemplo, que corresponde aos bairros da Zona Oeste, é responsável por mais da metade dos empreendimentos lançados pelo PMCMV com cerca de 55\% das áreas e unidades licenciadas no período entre 2009 e 2015. No outro extremo, a AP 2, que corresponde aos bairros da Zona Sul e Grande Tijuca, teve uma participação bastante residual no programa, sobretudo por conta dos altos preços dos terrenos, legislação rígida e pela quase saturação da área, dificultando a aquisição de terrenos que se enquadrem nos requisitos do programa. A AP 1, que abrange os bairros da região central e São Cristóvão, também teve uma participação bem pequena no programa no período. Os empreendimentos mais representativos dessa área são os condomínios Faixa 1 Zé Keti e Ismael Silva no bairro do Estácio, no terreno do antigo Complexo Penitenciário Frei Caneca.

Contribuindo com mais da metade dos empreendimentos lançados via PMCMV, a AP 5 é composta pelos bairros mais precarizados da cidade, localizados na Zona Oeste. É nesta área da cidade onde se encontra também a maior parte da população da cidade do Rio. Os empreendimentos da AP 5 estão, em sua maioria, enquadrados na Faixa 1 do programa. Devido a expressiva oferta de terrenos grandes e baratos, uma vez que boa parcela da área ainda preserva características rurais, muitas incorporadoras encontraram nesta área a possibilidade de construir empreendimentos de grandes dimensões. No bairro de Santa Cruz, por exemplo, a construtora Emccamp desenvolveu um complexo com 6 condomínios 
(Almada, Aveiro, Cascais, Coimbra, Estoril e Évora) justapostos, totalizando 2.265 unidades, numa área extremamente precária do ponto de vista da infraestrutura. Esse tipo de empreendimento e estratégia de ocupação, produzindo condomínios justapostos para otimizar a gestão do canteiro e também criar mecanismos de capitalização da terra com a ocupação de regiões não urbanizadas, caracterizam a Faixa 1 na AP 5. Uma vez que essa faixa de renda trabalha com demanda fechada e não há comercialização das unidades pelas incorporadoras, elas atuam no sentido de construir grandes empreendimentos em terrenos baratos, ainda que isso signifique a implantação em áreas sem qualquer tipo de infraestrutura para que "a conta feche", ou seja, para que as incorporadoras atinjam os rendimentos esperados.

Nesse sentido, fica evidente como o PMCMV reforça a fragilidade da questão urbana nesse processo uma vez que as incorporadoras passam a ser os principais agentes na produção do espaço urbano, já que os contratos dos empreendimentos do programa tornam débil o papel do Estado na gestão direta desses empreendimentos, ficando à cargo da relação direta entre as incorporadoras no papel de proponentes e a instituição financiadora (CEF) no papel da liberação e aprovação de crédito. Segundo Faulhaber (2015), por serem essas incorporadoras "os agentes proponentes dos empreendimentos, (...) passaram a ter ainda mais autonomia sobre a determinação da paisagem urbana, conquistando o poder de modificar a divisão econômico-social do espaço"147.

Ainda que o tema não esteja no escopo deste trabalho, vale ressaltar que no processo de pesquisa dos empreendimentos localizados na AP 5, foi constatado que praticamente todos se tornaram territórios ocupados por milícias que possuem uma atuação extremamente relevante na Zona Oeste da cidade, ganhando cada vez mais notoriedade e se consolidando como uma nova forma de gestão de periferias.

${ }^{147}$ FAULHABER, 2015, p. 119 
Figura 2. Empreendimentos Faixa 1 do PMCMV no bairro de Santa Cruz (AP 5)
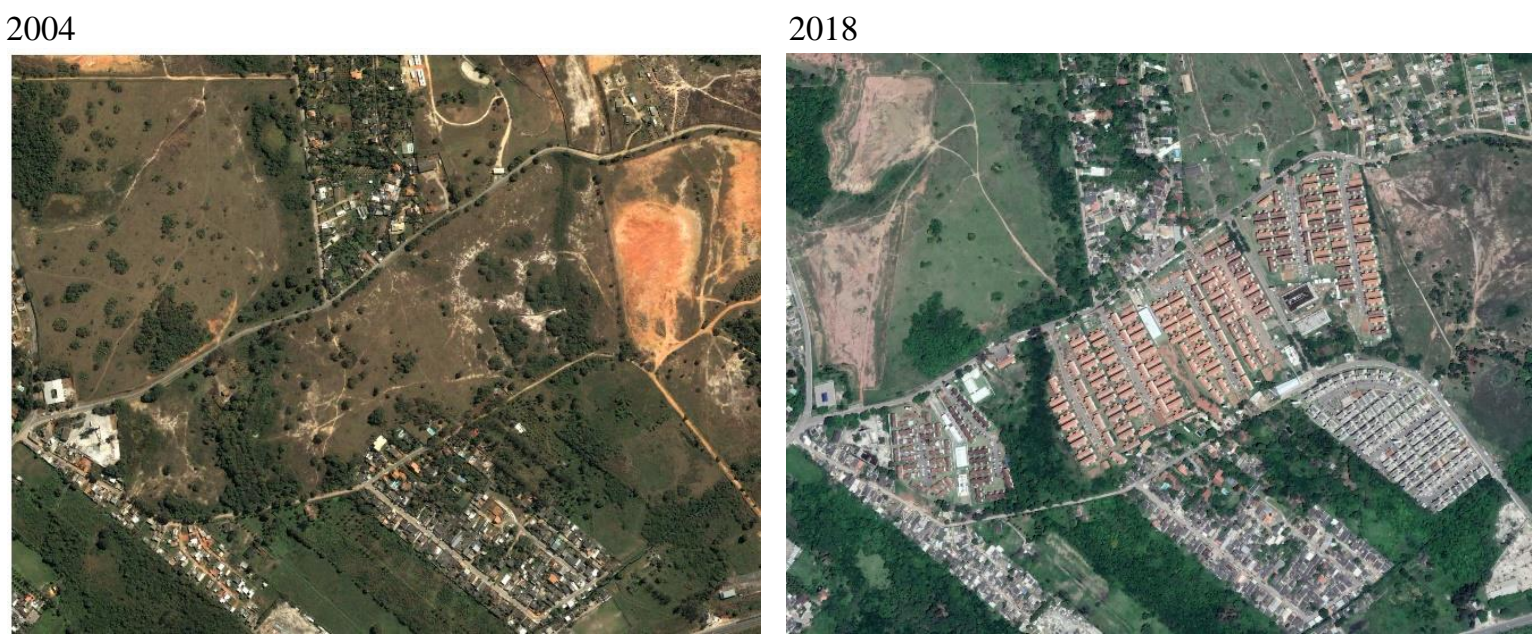

Fonte: Google Earth

Por último, a AP 3, que corresponde aos bairros da Zona Norte suburbana, é marcada pela heterogeneidade das tipologias, concentrando empreendimentos nas 3 faixas de renda estipuladas pelo programa. Diferentemente da AP 5 cujos empreendimentos Faixa 1 localizam-se basicamente em áreas extremamente inóspitas e precárias do ponto de vista das infraestruturas, na AP 3 esses empreendimentos possuem a particularidade de estarem localizados dentro ou em áreas limítrofes a favelas, configurando um outro tipo de precariedade. Talvez o empreendimento Faixa 1 mais emblemático desta AP seja o Bairro Carioca, localizado num terreno da antiga fábrica da $G E$, no bairro do Rocha, às margens da Linha 2 do metrô, onde foram produzidas um total de 2240 unidades pela construtora Direcional. Porém, outros empreendimentos de grande porte em bairros como Complexo do Alemão, Barros Filho, Costa Barros, Pavuna e Guadalupe, que receberam um grande contingente de famílias reassentadas em decorrência das obras do Programa de Aceleração do Crescimento (PAC), também ilustram esse quadro específico de precariedade. 
Figura 3. Condomínio Bairro Carioca no bairro do Rocha (AP 3)

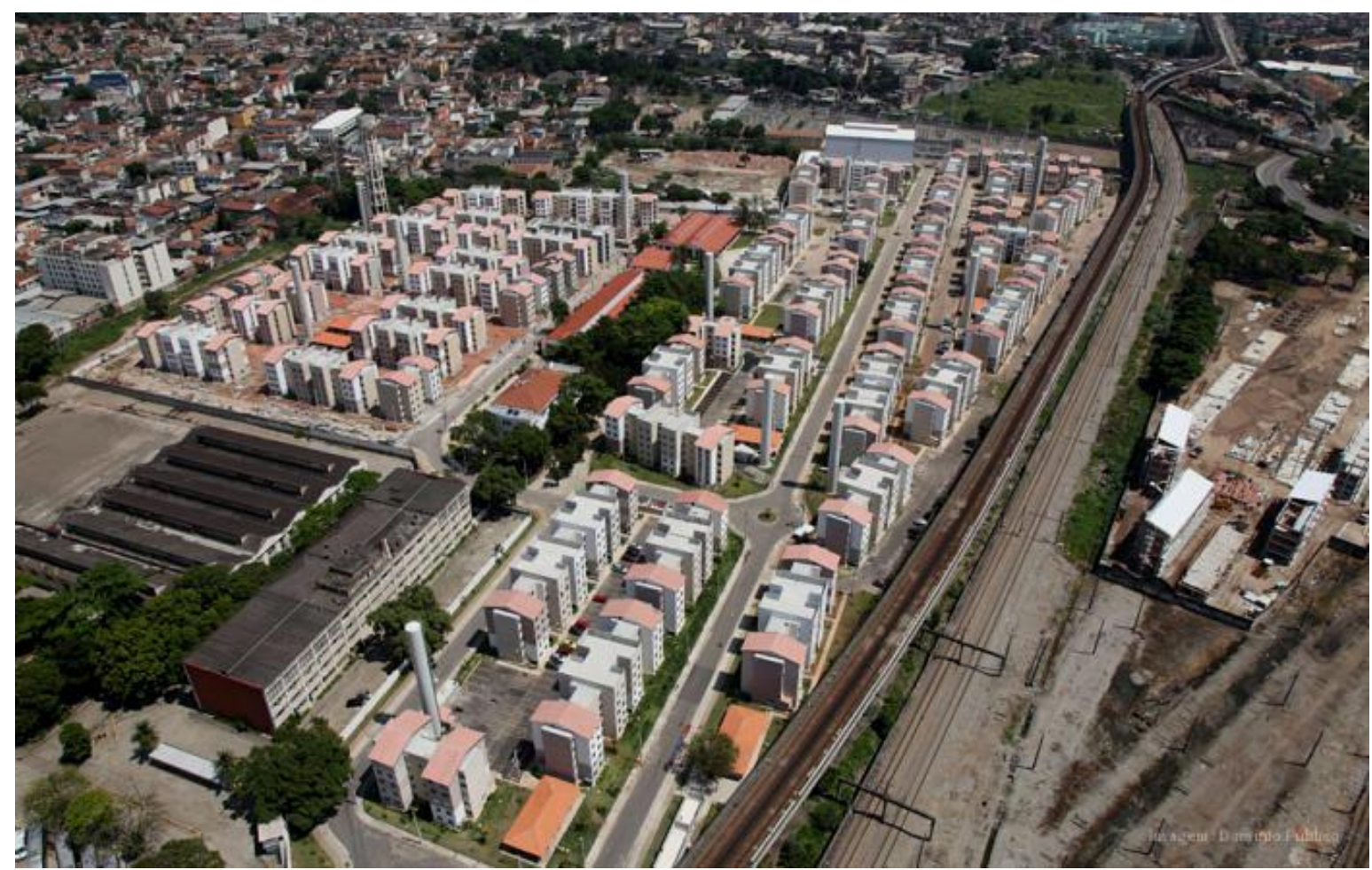

Fonte: Wikimapia ${ }^{148}$

A AP 3 também se configura por ser uma área da cidade que, apesar de possuir uma grande quantidade de terrenos ociosos decorrentes, em grande medida, da desindustrialização da área, dispõe de condições razoáveis no que diz respeito a infraestruturas de mobilidade e saneamento, bem como de equipamentos públicos, comércio e serviços. Tal característica foi importante para que as incorporadoras direcionassem seus investimentos vinculados às faixas de mercado (Faixa 2 e 3) para os bairros da área. A diversidade tipológica dos empreendimentos de mesma faixa também chama atenção. Ao mesmo tempo que se percebe condomínios com edifícios de até cinco pavimentos em áreas mais precárias, sem nenhuma qualidade construtiva e espacial, em outros casos nota-se a predominância da tipologia de condomínio-clube, com edifícios em altura (que requer a instalação de elevadores) e áreas de lazer, localizados em áreas com boa infraestrutura.

\footnotetext{
${ }^{148}$ http://wikimapia.org/1525276/pt/Bairro-Carioca-Triagem\#/photo/5191715
} 
Gráfico 5. Área licenciada pelo PMCMV e número de unidades licenciadas pelo PMCMV por Área de Planejamento no município do Rio de Janeiro (2009-2015) - \%

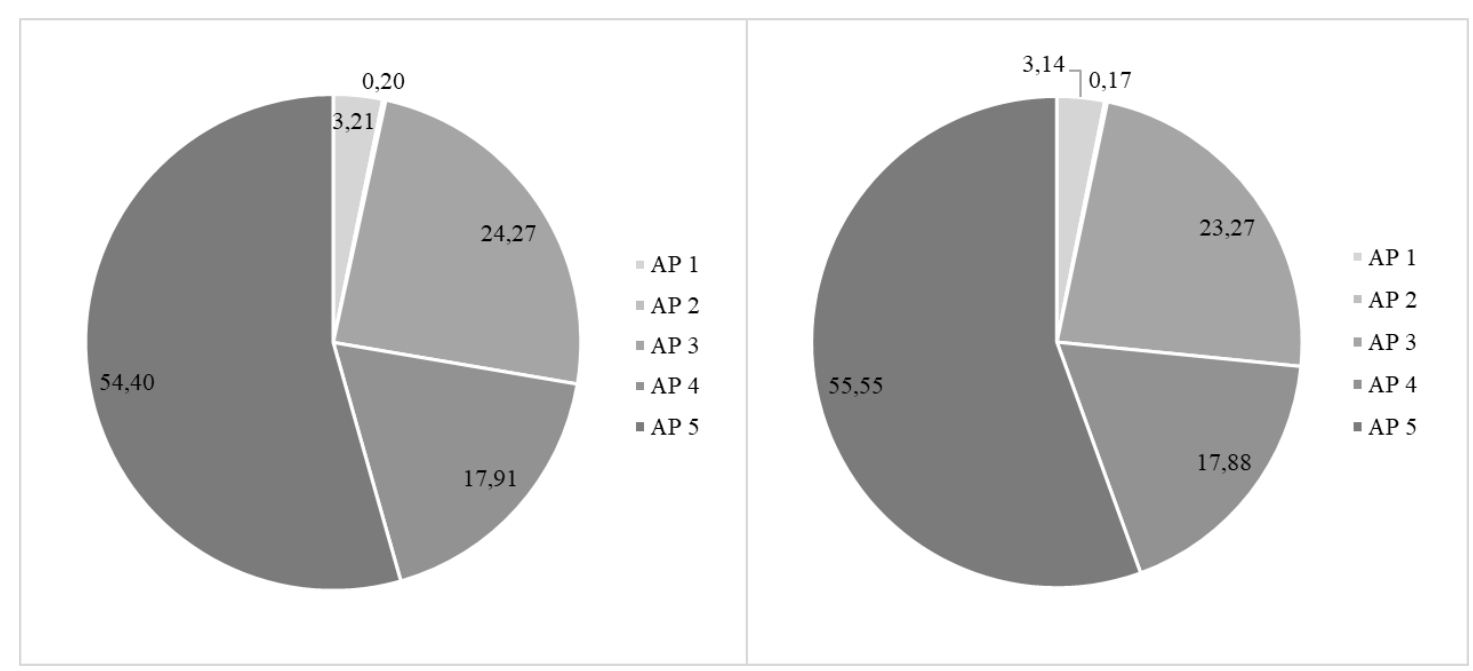

Fonte: Secretaria Municipal de Urbanismo

Em relação à distribuição de empreendimentos de acordo com as faixas de renda estipuladas pelo programa, o gráfico a seguir deixa claro o protagonismo das Faixas 1 e 3. No caso da Faixa 1, isso pode ser explicado pela iniciativa da prefeitura do Rio em criar condições para que as construtoras que atuavam na Faixa 1 pudessem lançar seus empreendimentos com incentivos, como a doação de terrenos em alguns casos, agilidade na aprovação de projetos e legislação especial. Contudo, o governo municipal não prescindiu desses empreendimentos com a finalidade de reassentar as famílias removidas de suas habitações em razão das obras realizadas no período. O exitoso caso da Faixa 3 também se deve aos benefícios em relação à flexibilização da legislação urbana e edilícia para esses empreendimentos, mas também pelo financiamento facilitado que o programa concedeu ao consumo, o que tornou vantajoso o lançamento de novos empreendimentos em áreas até então preteridas pelas incorporadoras. 
Gráfico 6. Área licenciada e número de unidades licenciadas por faixa de renda do PMCMV no município do Rio de Janeiro (2009-2013) - \%

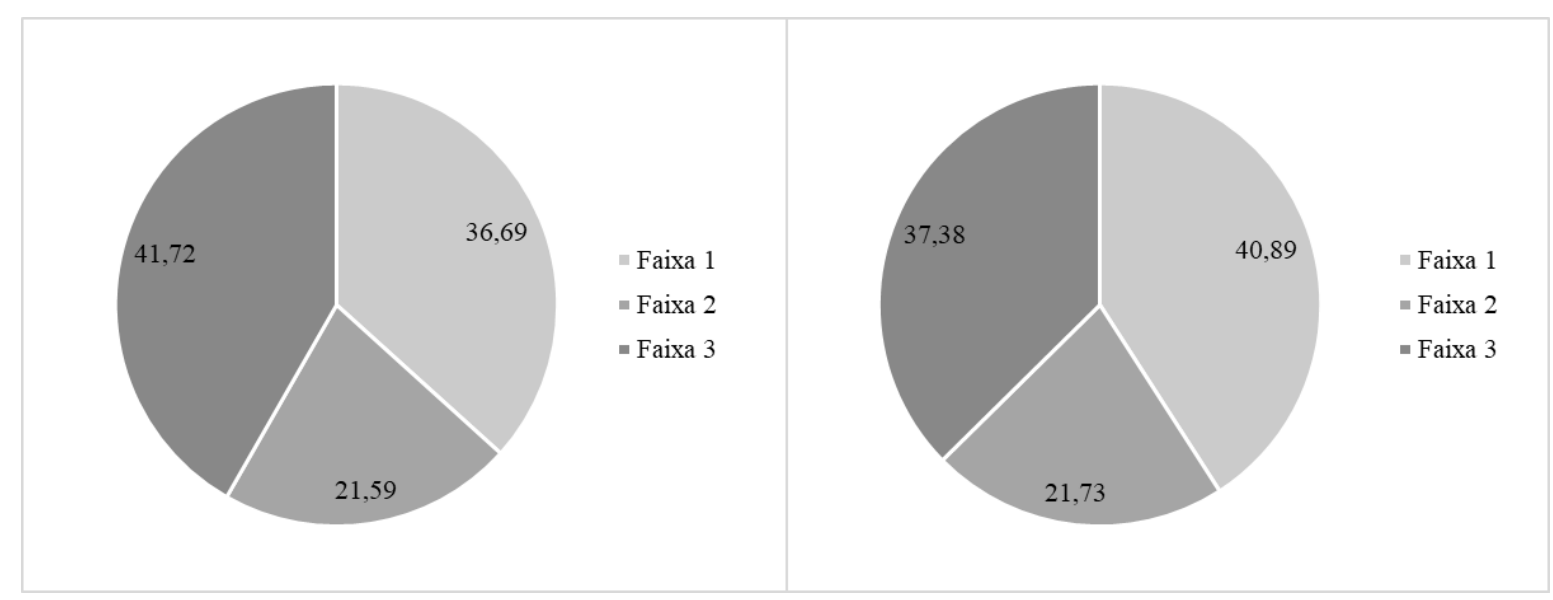

Fonte: Secretaria Municipal de Urbanismo

Algo que chama bastante atenção nos gráficos anteriores e que torna a produção vinculada ao PMCMV no município do Rio de Janeiro bastante particular, é a proporção dos empreendimentos em cada faixa em relação ao cenário do programa no contexto nacional. Enquanto no Rio as Faixas 1 e 3 são protagonistas, no cenário nacional, a Faixa 2 - que possui subsídio direto de cerca de $12 \%$ do preço do imóvel - é a mais relevante, sendo responsável por $51 \%$ de toda a produção do programa, segundo relatório elaborado pela Associação Brasileira de Incorporadoras Imobiliárias (ABRAINC). Neste mesmo cenário a participação da Faixa 3 se resume a apenas 12\% de toda produção. O mapa a seguir mostra a distribuição dos empreendimentos vinculados ao PMCMV na cidade do Rio de Janeiro, revelando o protagonismo da AP 3 e AP 5, cada uma com características particulares dentro do Programa. 
Mapa 2. Empreendimentos lançados pelo PMCMV no Rio de Janeiro (2009-2015)

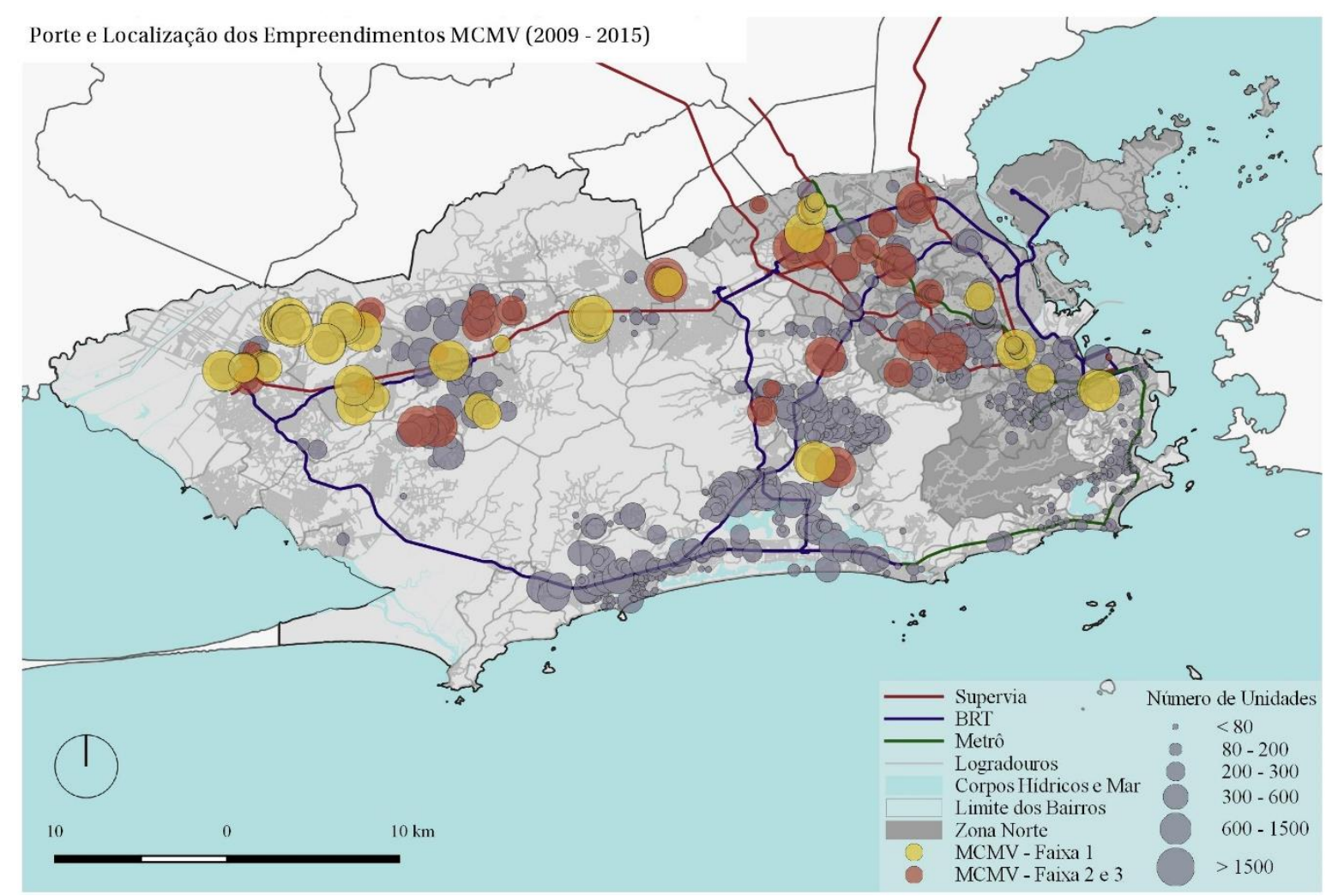

Fonte: elaboração do autor em parceria com Paula C. Moreira a partir de dados da Ademi, CEF e IPP

\section{Alteração das legislações urbana e edilícia: o Plano Diretor de 2011 e outros instrumentos}

Quando o prefeito Eduardo Paes ${ }^{149}$ tomou posse de seu primeiro mandato em janeiro de 2009, a produção imobiliária na capital carioca já estava em franca expansão. Além disso, a possibilidade de receber os Jogos Olímpicos em 2016 se mostrava bastante possível, o que acabou se confirmando alguns meses depois. O Programa Minha Casa Minha Vida também estava prestes a ser lançado como política pública federal e, como discutido anteriormente, o Rio foi uma das principais cidades a associar-se ao programa. Além disso, o estado do Rio vinha retomando o crescimento econômico a partir da exploração de petróleo e derivados no Leste e Norte Fluminense. Em síntese, as condições gerais para as transformações a partir da produção do espaço na cidade estavam lançadas.

\footnotetext{
149 Após longa trajetória política em diversos partidos, ocupando cargos em subprefeituras, secretarias do município e estado, além de um mandato como vereador e outro como deputado federal, Paes foi eleito prefeito do Rio pelo PMDB e cumpriu dois mandatos entre os anos de 2009 e 2016.
} 
Imbuído do receituário neoliberal de gestão de cidades e planejamento estratégico, o então prefeito procurou montar sua equipe em consonância com essas ideias e com a expertise da iniciativa privada, estreitando essas relações para firmar parcerias público-privadas (PPP) em projetos, viabilizando a concessão de serviços públicos urbanos, criando novos instrumentos urbanísticos e flexibilizando as legislações em áreas estratégicas para o setor imobiliário com o objetivo de tirar os projetos do papel com mais rapidez. Esta mesma equipe foi responsável, por exemplo, pelo desenho institucional que viabilizou a OUC Porto Maravilha. Em entrevista à revista Construir, o então secretário de urbanismo, Sérgio Moreira Dias corrobora essas ideias afirmando que

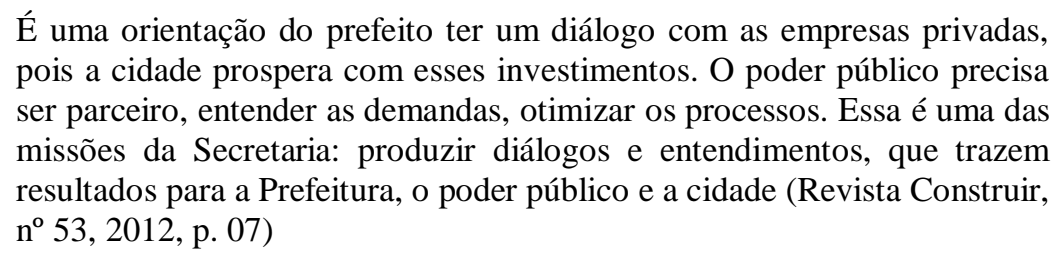

Tendo essas ideias como premissa, foi aprovado no início de 2011 o novo Plano Diretor municipal ${ }^{150}$ que segue em atividade até os dias atuais e que trouxe novos instrumentos de gestão de uso e ocupação do solo previstos no Estatuto da Cidade ${ }^{151}$ e que até então não estavam previstos em textos legais do município, como o Direito de Preempção, que concede ao poder público a preferência na aquisição de imóveis em determinadas localidades, a Outorga Onerosa do Direito de Construção e de Alteração de Uso, que libera o direito de construir acima dos índices de aproveitamento dos terrenos mediante contrapartida a ser prestada pelo beneficiário, a Transferência do Direito de Construir que autoriza, em casos específicos e em áreas de Operação Urbana, o proprietário de imóvel urbano a exercer em outro local o direito de construir previsto no plano diretor e a instituição de Operações Urbanas Consorciadas. Apesar dos instrumentos acima indicados serem citados de maneira genérica no PDDUS, se limitando a transcrever os pontos elencados no Estatuto da Cidade sem maiores detalhes, eles funcionaram como ferramentas poderosas na transformação do espaço e na gestão territorial da cidade.

A publicação do Plano data de 2011. Como pode ser visto nos itens anteriores, a expansão imobiliária já estava em franca expansão desde de 2007 e os empreendimentos vinculados ao PMCMV impulsionaram ainda mais essa expansão. Além disso, as obras de construção

\footnotetext{
${ }^{150}$ Plano Diretor de Desenvolvimento Urbano Sustentável (PDDUS) - Lei Complementar 111/2011.

${ }^{151}$ Lei 10.257/2001 que regulamenta os artigos 182 e 183 da Constituição Federal e estabelece diretrizes gerais da política urbana.
} 
de novas infraestruturas e equipamentos voltados para os Jogos Olímpicos já era uma realidade. Dessa forma, pode-se dizer que o plano teve muito mais um papel de ratificar e coroar as transformações que vinham acontecendo e ao mesmo tempo garantir através desse instrumento a sua continuidade e potencialização sob um arcabouço jurídico institucional. Nessa lógica, o plano divide a cidade em quatro grandes Macrozonas onde são definidos vetores de crescimento específicos para cada uma delas, dando claro destaque às que abarcavam a Zona Norte, Zona Oeste, baixada de Jacarepaguá e região portuária, não por acaso, as áreas da cidade que mais se transformaram no período estudado, seja através da produção imobiliária, seja através de grandes obras de infraestrutura, como será abordado adiante. Segundo o PDDUS, esse macrozoneamento é dividido da seguinte forma:

- Macrozona de Ocupação Controlada, onde o adensamento populacional e a intensidade construtiva serão limitados, a renovação urbana se dará preferencialmente pela reconstrução ou pela reconversão de edificações existentes e o crescimento das atividades de comércio e serviços em locais onde a infraestrutura seja suficiente, respeitadas as áreas predominantemente residenciais;

- Macrozona de Ocupação Incentivada, onde o adensamento populacional, a intensidade construtiva e o incremento das atividades econômicas e equipamentos de grande porte serão estimulados, preferencialmente nas áreas com maior disponibilidade ou potencial de implantação de infraestrutura;

- Macrozona de Ocupação Condicionada, onde o adensamento populacional, a intensidade construtiva e a instalação das atividades econômicas serão restringidas de acordo com a capacidade das redes de infraestrutura e subordinados à proteção ambiental e paisagística, podendo ser progressivamente ampliados com o aporte de recursos privados;

- Macrozona de Ocupação Assistida, onde o adensamento populacional, o incremento das atividades econômicas e a instalação de complexos econômicos deverão ser acompanhados por investimentos públicos em infraestrutura e por medidas de proteção ao meio ambiente e à atividade agrícola ${ }^{152}$

${ }^{152}$ PDDUS, 2011, pp. 14-15 
Mapa 3. Macrozoneamento da cidade do Rio de Janeiro - PDDUS 2011

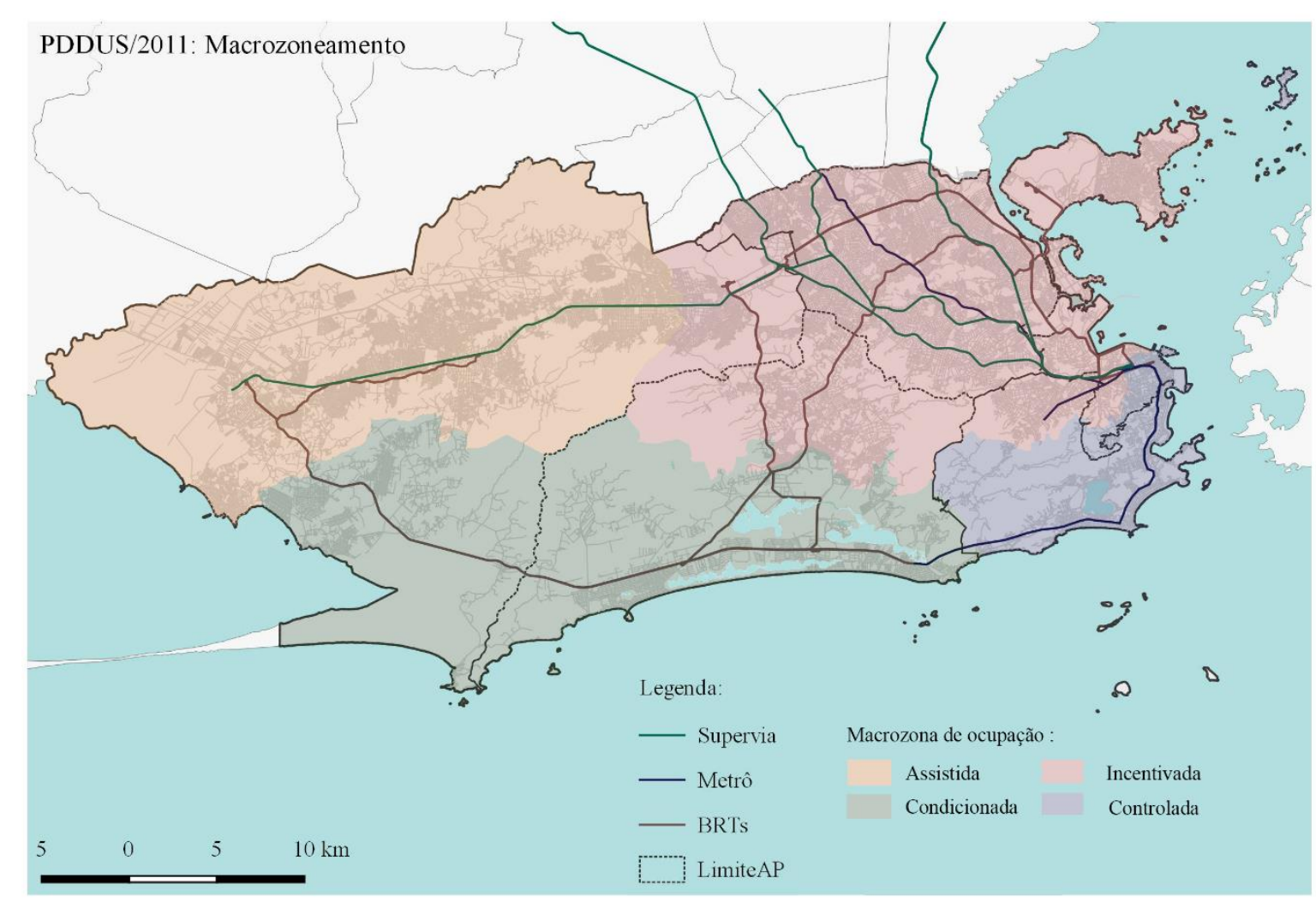

Fonte: elaboração do autor a partir de dados do PDDUS/2011

A ocupação urbana no município se orientará segundo os seguintes vetores de crescimento:

- pelo adensamento da população e das construções na Macrozona de Ocupação Incentivada, preferencialmente nas vias estruturadoras da Zona Norte, da Leopoldina e de Jacarepaguá;

- pela reconversão de edificações nas Macrozonas de Ocupação Incentivada na área central e adjacências;

- pela ocupação de vazios urbanos nas Macrozonas de Ocupação Incentivada e Ocupação Assistida, especialmente na faixa de território compreendida pela Av. Brasil e o leito da estrada de ferro, na Zona Oeste, e a Zona Portuária;

- pela intensificação da ocupação nas Macrozonas de Ocupação Incentivada e de Ocupação Assistida, junto aos centros de comércio e de serviços, às áreas industriais e aos eixos viários estruturadores do espaço na Zona Norte e da Leopoldina e na Zona Oeste;

- pela expansão da malha urbana nas Macrozonas de Ocupação Assistida e de Ocupação Condicionada a partir da associação de investimentos da iniciativa privada aos recursos 
federais, estaduais e municipais para implantação de infraestrutura e equipamentos urbanos $^{153}$

Mapa 4. Ocupação territorial e vetores de crescimento - PDDUS 2011

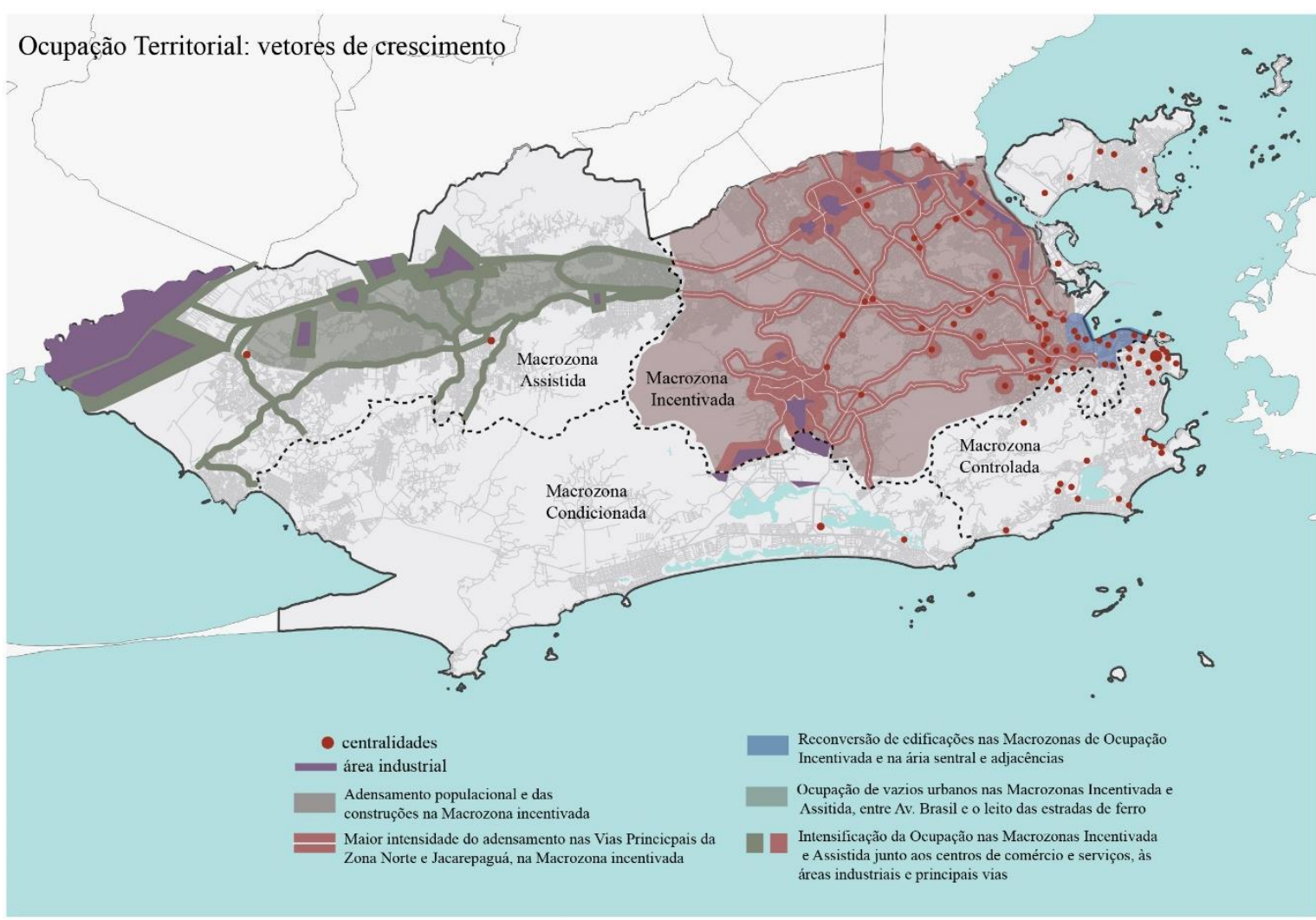

Fonte: PDDUS/2011, disponível na SMU

O texto do Plano propõe a descentralização das atividades econômicas de comércio e serviços, bastante concentrada nos bairros da Zona Sul e Barra, e estimular o fortalecimento dessas atividades nas centralidades dos bairros da Macrozona Incentivada, como Tijuca, Madureira e Taquara. Além disso, como se pode ver no mapa, a Macrozona Incentivada estimula também o adensamento populacional e de novas construções em toda sua área e, de maneira mais intensificada, nas principais vias da Zona Norte e de Jacarepaguá, sobretudo nos arredores da TransCarioca, TransOlímpica, Av. Brasil (TransBrasil) e Estádio Olímpico Nilton Santos (Engenhão), pela instituição de AEIUs ${ }^{154}$. Não por acaso eram essas áreas onde a produção imobiliária já se concentrava. Lencioni (2013) aponta para essa questão da

\footnotetext{
${ }^{153}$ Ibid., p. 15

${ }^{154}$ A SMU informa que segundo o Plano Diretor, a Área de Especial Interesse Urbanístico (AEIU) é uma área submetida a regime urbanístico específico, relativo a implementação de políticas públicas de desenvolvimento urbano e formas de controle que prevalecerão sobre os controles definidos para as Zonas e Subzonas que a contêm. A Área de Especial Interesse Urbanístico é aquela destinada a projetos específicos de estruturação ou reestruturação, renovação e revitalização urbana.
} 
urgência da produção de novas centralidades no espaço urbano contemporâneo ao declarar que "elas são produzidas muito menos pelas necessidades da cidade desempenhar as funções de comércio e de serviços e, muito mais, devido às necessidades de reprodução do capital no setor imobiliário" $" 155$.

As Macrozonas de Ocupação Incentivada e Assistida teriam, segundo o texto legal, prioridade na aplicação de investimentos públicos, inclusive os oriundos de recursos gerados pela aplicação dos instrumentos onerosos de gestão de uso e de ocupação do solo já citados anteriormente e previstos especialmente para as outras Macrozonas. Além disso, foram estabelecidas normas mais flexíveis visando a produção de unidades novas para moradia popular e a garantia do poder público na provisão de infraestruturas básicas e outros serviços públicos.

No sentido de estimular ainda mais a produção imobiliária em alguns bairros tidos como estratégicos para o mercado imobiliário, a prefeitura intensificou a elaboração de Projetos de Lei que instituíssem novos PEUs ${ }^{156}$. Alguns alcançaram o status de lei, como os PEUs da Penha, das Vargens, da Taquara e de Campo Grande. Outros ainda tramitam na Câmara dos Vereadores, como o PEU da Ilha, de São Francisco Xavier e o de Madureira.

${ }^{155}$ LENCIONI, 2013, p. 29

${ }^{156}$ Segundo a SMU, o Plano de Estruturação Urbana (PEU) é o instrumento normativo básico de intervenção urbanística para um bairro ou conjunto de bairros, instituídos através de Lei Complementar. O PEU estabelece as diretrizes que nortearão o uso e a ocupação da área estudada além de estabelecer os parâmetros urbanísticos básicos (gabarito, taxa de ocupação, taxa de permeabilidade, área total edificável, afastamentos, usos, etc.). 
Mapa 5. Bairros onde os PEUs foram instituídos ou que ainda tramitam na Câmara

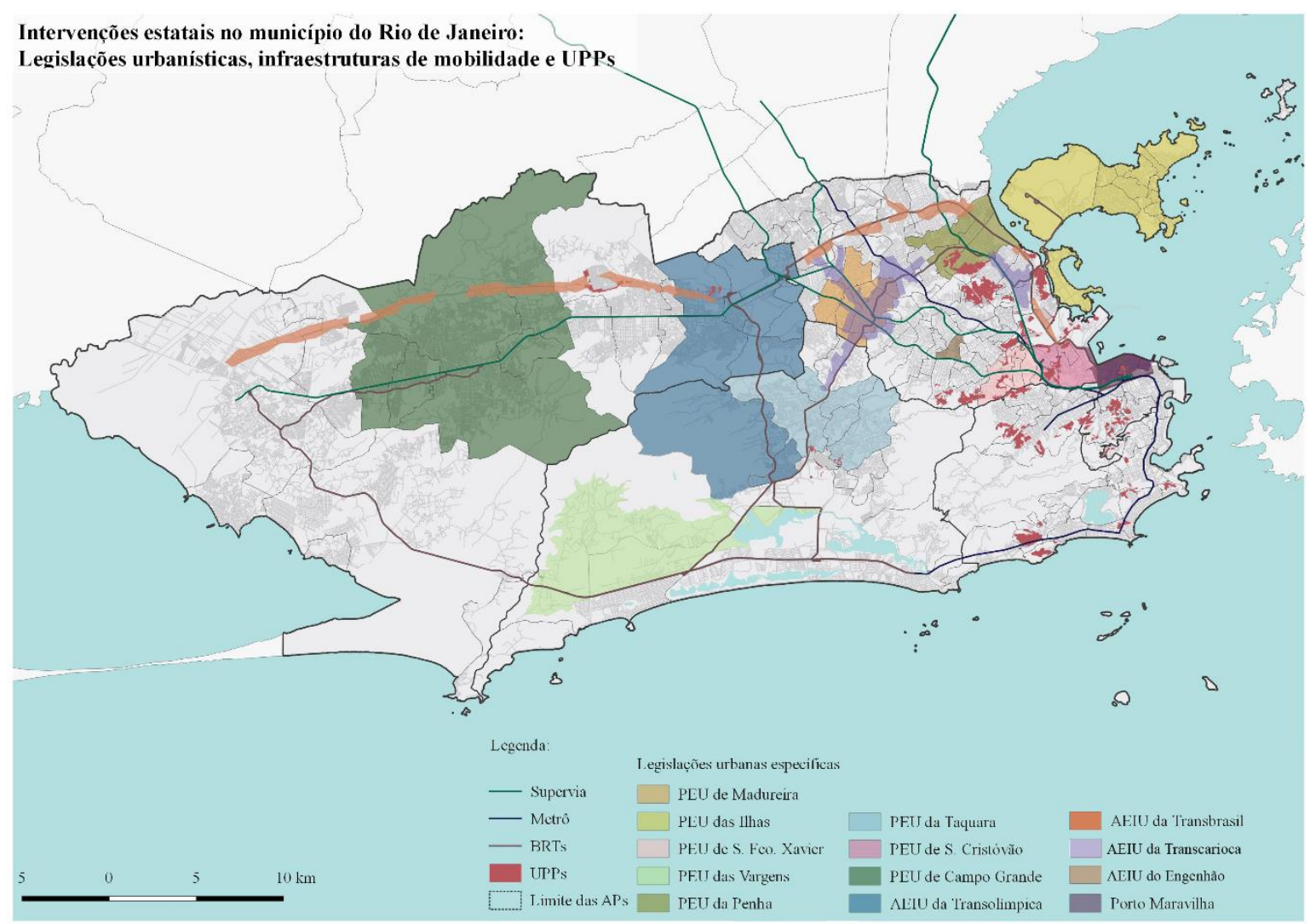

Fonte: elaboração do autor através dos dados da SMU

A instituição desses planos e dos instrumentos previstos no PDDUS como lei, não garantiu que eles fossem implementados em sua plenitude. Em alguns casos, sequer foram colocados em prática ou até mesmo arquivados. Com a crise do mercado imobiliário na cidade a partir de 2014, reflexo da crise do setor em âmbito nacional, esses planos e instrumentos se configuram como uma promessa futura de mobilização do espaço numa eventual retomada da produção. Por outro lado, a instituição dos mesmos tem um impacto significativo no preço da terra, pois, uma vez que ela funciona como capital fictício, esses instrumentos trazem a garantia de que o proprietário dos terrenos nessas áreas possa capitalizar a sua renda numa eventual transação tendo em vista a rentabilidade que os empreendimentos alcançarão no futuro. Faulhaber (2015) assinala que "o novo padrão de organização do espaço urbano imposto pelos incorporadores imobiliários foi capaz de superar quase a totalidade das barreiras legais, físicas, simbólicas e econômicas a fim de criar novas espacialidades para acumulação do capital"157.

${ }^{157}$ FAULHABER, 2015, p. 104 
Dessa forma, cada espaço do Rio de Janeiro assumiria um papel sobre as pretensões dos agentes do poder público ou do mercado imobiliário, cabendo ao Estado regular e mediar as formas de apropriação destes territórios pelo capital privado. De acordo com este princípio, surgem as formas fragmentadas e híbridas de planejamento urbano. A fim de garantir ganhos específicos a agentes seletos que já possuem determinado domínio em âmbito local, são criadas as novas áreas de acumulação. (FAULHABER, 2015, pp. 109-110)

\section{Provisão de novas infraestruturas de mobilidade urbana}

Visando atender as exigências de infraestruturas mínimas para realização dos Jogos Olímpicos, o governo municipal carioca lançou um amplo projeto de infraestrutura viária através de corredores exclusivos conhecidos como BRT (Bus Rapid Transit). Esse projeto previu a implementação de quatro grandes corredores, dos quais três estão em funcionamento e um - a TransBrasil - ainda se encontra em fase de obras. A gestão dos BRTs é feita por um grupo de empresas privadas que tradicionalmente fazem parte do oligopólio que detém o controle do sistema de transporte público rodoviário da cidade, reunidas em consórcio.

A TransOeste foi o primeiro corredor a entrar em operação. Sua primeira fase, que liga o Terminal Alvorada na Barra da Tijuca ao bairro de Santa Cruz na Zona Oeste, foi inaugurada em 2012. Posteriormente, em 2016, foi inaugurado o trecho que liga o Terminal Alvorada à Linha 4 do metrô também na Barra. O corredor totaliza cerca de $60 \mathrm{~km}$ de extensão e conta com 62 estações. O sistema atende uma demanda de 216 mil passageiros por dia, segundo dados do próprio consórcio. Os recursos financeiros para realização da obra - cerca de 1 bilhão de reais - foram oriundos do PAC. O corredor atravessa bairros que se encontram dentro das Macrozonas Condicionada e Assistida, caracterizadas pela disponibilidade de grandes terrenos ociosos e infraestrutura precária em sua maior parte. Contudo, no entorno das estações da TransOeste (raio de 500m) foram licenciadas, entre 2009 e 2015, 8,25\% dos mais de 34 milhões de $\mathrm{m}^{2}$ licenciados em toda a cidade no período indicado.

Ligando o Terminal Alvorada ao Aeroporto Tom Jobim na Ilha do Governador, a TransCarioca possui cerca de $39 \mathrm{~km}$ de extensão ao longo de 45 estações. O corredor passou a operar a partir de 2014 tendo em vista a Copa do Mundo e possui capacidade para atender 234 mil passageiros por dia, segundo dados da concessionária. O trajeto da TransCarioca faz importantes integrações modais (não necessariamente com a mesma tarifa) com a própria TransOeste na Alvorada, com a Supervia em Madureira e Olaria, com a Linha 2 do Metrô 
em Vicente de Carvalho e com a TransBrasil quando esta passar a operar. Os recursos que totalizam 2 bilhões de reais também são oriundos do PAC. Segundo Faulhaber (2015), de todo este montante, cerca de $10 \%$ serviram para pagar as desapropriações realizadas ao longo do seu percurso. Como é sabido, a partir de 2010 muitas famílias cariocas passaram pelo maior processo de remoções forçadas já ocorrido na cidade em decorrência das obras de infraestrutura para os Jogos Olímpicos e a maior parte dessas remoções ocorreram justamente ao longo da TransCarioca. O corredor atravessa as Macrozonas Condicionada e Incentivada, onde havia grande disponibilidade de terrenos, embora com preços mais elevados e boa oferta de infraestrutura. A instituição de legislações específicas para bairros cortados pela TransCarioca (PEU Taquara, PEU Madureira, PEU Penha, entre outros) ajudam a intensificar o quadro de expansão do setor imobiliário na região. As áreas licenciadas para construção no entorno das estações da TransCarioca compreenderam, entre 2009 e 2015, 7,07\% do montante total licenciado na cidade no mesmo período.

Por sua vez, o corredor da TransOlímpica tem, segundo dados da concessionária, capacidade para atender cerca de 70 mil passageiros por dia, ao longo de seus 26 quilômetros e 18 estações. O corredor liga o bairro do Recreio dos Bandeirantes a Deodoro, ambos na Zona Oeste, e se integra (não necessariamente com a mesma tarifa) com a Supervia tanto em Deodoro quanto em Magalhães Bastos, além da integração com a TransOeste no Recreio. A construção da TransOlímpica teve como objetivo inicial, a interligação mais rápida entre os locais que sediariam modalidades dos Jogos. Correndo em paralelo à TransOlímpica, existe uma via expressa para veículos automotores cujo percurso, administrado pela concessionária ViaRio S.A, é feito a partir do pagamento de pedágio. Um montante de 2,5 bilhões de reais foram necessários para construção do corredor advindos de recursos privados bancados pela concessionária que a administra. A área de influência de suas estações contribuiu com cerca de 3,95\% das áreas licenciadas em toda a cidade no período entre 2009 e 2015.

Dentre os corredores expressos de BRT, o único que ainda se encontra em fase de obras é a TransBrasil que, ao longo dos seus $30 \mathrm{~km}$ de extensão, acompanha o traçado da Av. Brasil, principal via de acesso do subúrbio do Rio e Baixada Fluminense ao Centro. A via também é a principal forma de ligação com as rodovias que liga a capital Fluminense a outros estados, como São Paulo, Minas Gerais e Espírito Santo. Sua importância para cidade é tamanha que o modal tem expectativa de atender cerca de 900 mil passageiros/dia, segundo dados da prefeitura do Rio. O corredor ligará o Centro da cidade com o bairro de Deodoro e fará 
integração com outros sistemas de transporte (não necessariamente com a mesma tarifa), como a TransCarioca, a Linha 1 do Metrô, com a Supervia em Parada de Lucas e com o VLT na Rodoviária Novo Rio. De acordo com Faulhaber (2015), a obra está enquadrada no PAC Mobilidade e seu orçamento de 1,5 bilhões de reais é custeado pela prefeitura do Rio e governo federal. As diretrizes urbanísticas para o entorno da TransBrasil preveem o adensamento populacional da área e o estímulo a novas construções a partir da instituição da AEIU Avenida Brasil. Nesse sentido, cerca de 5\% do total de áreas licenciadas na cidade entre 2009 e 2015 estão no entorno imediato da via.

A Linha 4 do metrô que liga Ipanema ao Jardim Oceânico na Barra da Tijuca, contribuiu muito pouco para a expansão imobiliária no entorno de suas estações $(0,62 \%)$, uma vez que a linha localiza-se na Zona Sul que, apesar de ter tido um avanço no lançamento de novos empreendimentos imobiliário entre 2007 e 2015, está bem aquém do restante da cidade, devido a sua quase saturação com poucos terrenos disponíveis e legislações mais restritas. Já as Linhas 1 e 2 do Metrô e os ramais da Supervia são infraestruturas de mobilidade antigas na cidade. $\mathrm{O}$ último trecho concluído na Linha 2, infraestrutura de mobilidade mais recente dentre as citadas, começou a ser operacionalizada em 1998, portanto não tendo qualquer relação com a expansão imobiliária recente ou com legados de Megaeventos. Porém, o que se nota é que a partir dessa conjuntura favorável para expansão do setor, os entornos das dessas infraestruturas passam a ser disputados e apropriados nesse processo de expansão imobiliária. É possível notar a concentração de novos empreendimentos imobiliários ao longo da Linha 2 do Metrô, em especial nos cruzamentos com outras infraestruturas de mobilidade, como o BRT TransCarioca e até mesmo a Linha Amarela.

Essas infraestruturas, antigas ou novas, viabilizadas pelo Estado através do aporte de fundos públicos ou paraestatais, "são capturadas pela racionalidade capitalista e condicionadas aos interesses exclusivos da reprodução do capital" ${ }^{\text {"158 }}$. Lencioni prossegue assinalando que

\footnotetext{
A produção dessas infraestruturas se coloca cada vez mais como negócios do capital, uma vez que o Estado vem refluindo na sua competência de prover tais infraestruturas ou de dirigir o processo de seu desenvolvimento. Consequentemente, o que se vê é que o processo de metropolização se faz acompanhar do crescimento da participação da iniciativa privada na provisão dessas infraestruturas" (LENCIONI, 2013, p. 31)
}

${ }^{158}$ LENCIONI, 2013, p. 31 
Tabela 5. Área licenciada total e total de unidades no entorno (500m de raio) de cada estação dos BRT TransOeste, TransCarioca, TransOlímpica, TransBrasil, Linhas 1, 2 e 4 do Metrô e ramais da Supervia (2009 a 2015)

\begin{tabular}{lrrr}
\hline Sistema de Transporte & \% & Área Total $\left(\mathbf{m}^{2}\right)$ & Total Unidades \\
\hline Transoeste & 8,25 & 2.844 .510 & 21.068 \\
Transcarioca & 7,13 & 2.459 .935 & 19.542 \\
Transolímpica & 3,95 & 1.361 .729 & 10.861 \\
Trans brasil & 4,82 & 1.661 .762 & 4.589 \\
Metrô Linha 4 & 0,62 & 212.250 & 984 \\
Metrô Linhas 1 e 2* & 0,94 & 323.295 & 2.441 \\
Supervia** & 5,60 & 1.930 .711 & 18.588 \\
Total acumulado & $\mathbf{3 1 , 3 1}$ & $\mathbf{1 0 . 7 9 4 . 1 9 2}$ & $\mathbf{7 8 . 0 7 3}$ \\
Total do Município & $\mathbf{1 0 0}$ & $\mathbf{3 4 . 4 8 1 . 8 8 1}$ & $\mathbf{2 5 4 . 6 4 1}$ \\
\hline * Dados de 2014 e 2015 & ** Estações localizadas no município do Rio de Janeiro &
\end{tabular}

A tabela anterior exprime o percentual dos empreendimentos licenciados acima de $800 \mathrm{~m}^{2}-$ $31,31 \%$ - no entorno das estações das grandes infraestruturas de mobilidade frente ao total licenciado no município no mesmo período. Em que pese a dificuldade de se precisar com exatidão o quanto o somatório dessas áreas consideradas "entorno" representam na área total do território do município, é possível afirmar que não são preponderantes, o que reforça o argumento de que esses empreendimentos se concentram estrategicamente nessas áreas, revelando como o mercado imobiliário passa a se apropriar de forma privilegiada dessas infraestruturas para auferir ganhos cada vez maiores a partir dessa produção.

\section{As Unidades de Polícia Pacificadora (UPPs)}

A UPP foi uma política de segurança pública criada e coordenada pela Secretaria Estadual de Segurança do Rio de Janeiro e capitaneada pelo então secretário José Mariano Beltrame que tinha como objetivo a ocupação policial de favelas dominadas pelo tráfico organizado. Franco (2014) ressalta que, embora as UPPs tenham sido estabelecidas enquanto lei apenas em 2011 pelo Decreto $n^{\circ}$ 42.787, a primeira instalação da unidade ocorrera em 2008, no Morro Dona Marta em Botafogo. A partir disso, até o ano de 2014, foram implementadas mais 37 unidades distribuídas desigualmente pela cidade, com maior presença nas favelas 
da Zona Sul e Zona Norte e mobilizando um efetivo de 9.343 policiais militares ${ }^{159}$. A ocupação teve influência direta em mais de 200 comunidades cariocas.

Em decorrência dos Megaeventos que se aproximava, a implementação das UPPs como política pública foi um elemento fundamental para colocar a cidade do Rio de Janeiro como o centro das atenções no mundo e como estratégia de propaganda acerca da criação e "legados". Porém, a ocupação de favelas estrategicamente escolhidas, foi também uma importante estratégia utilizada pelo setor imobiliário para lançamentos de novos empreendimentos imobiliários e como instrumento de capitalização da propriedade da terra em áreas próximas a favelas ocupadas. Segundo reportagem da Construção Mercado,

\begin{abstract}
um levantamento feito pelo Secovi Rio mostra que, entre abril de 2006 e dezembro de 2008, a valorização dos apartamentos de dois quartos no Botafogo foi de apenas 24,95\%, enquanto de 2008 a agosto de 2011, os preços subiram $105,32 \%$ e chegaram à média de $\mathrm{R} \$ 676$ mil. Com o sucesso da primeira experiência, a pacificação seguiu por outras comunidades da zona sul, sempre com efeitos positivos sobre os preços dos imóveis ao redor, principalmente nas ruas mais próximas à favela. O Secovi acompanhou as primeiras ocupações e calculou uma valorização média de $30 \%$ a $40 \%$ nos bairros vizinhos ${ }^{160}$.
\end{abstract}

As primeiras UPPs foram instaladas em favelas localizadas nos bairros mais valorizados da Zona Sul, como o Chapéu-Mangueira e Babilônia no Leme, Dona Marta em Botafogo e Cantagalo e Pavão-Pavãozinho no limite entre Copacabana e Ipanema. Contudo, a variação do preço do $\mathrm{m}^{2}$ dos imóveis na região não atingiu os mais altos patamares registrados na cidade, uma vez que outros aspectos influenciam nessa variação como o próprio preço da terra já consideravelmente elevado e a quase saturação da região, o que torna escasso terrenos para construção. Como as fronteiras de acumulação a partir do imobiliário foram ampliadas para novas regiões da cidade como a Zona Norte que historicamente conviveu e ainda convive com altos índices de criminalidade, a instituição das UPPs foram fundamentais para a elevação do padrão de acumulação e aceleração das vendas. Em entrevista, o então vice-presidente do Secovi Rio, Leonardo Schneider, deixa clara a importância das UPPs para a estratégia de atuação do setor imobiliário na Zona Norte: "ali, a UPP foi fundamental para o resgate de bairros e ruas que estavam degradados, esquecidos e sem nenhuma liquidez para transações imobiliárias"161.

\footnotetext{
159 http://www.upprj.com/index.php/o_que_e_upp

160 “O Efeito UPP” - Revista Construção Mercado, fevereiro/2012

http://construcaomercado17.pini.com.br/negocios-incorporacao-construcao/127/o-efeito-upp-a-pacificacaode-favelas-no-rio-282612-1.aspx

161 Ibid.
} 
A Grande Tijuca, onde está localizado um dos principais equipamentos esportivos que serviu aos Megaeventos - o Maracanã -, aparece como um caso emblemático nesse processo de aumento dos preços dos imóveis decorrentes do processo de "pacificação" de um grande número de suas favelas. Os dados do Fipe-Zap mostram que em 2008, o preço do $\mathrm{m}^{2}$ residencial na Tijuca girava em torno de R 2 mil. Desde a instalação das UPPs o preço do $\mathrm{m}^{2}$ desses imóveis registraram uma valorização de cerca de $280 \%$ em 2012. Já o preço médio das unidades comerciais atingira a casa dos $\mathrm{R} \$ 8$ mil por $\mathrm{m}^{2}$. Em entrevista, João Paulo Matos, presidente da Calçada Engenharia, aponta que "sem a UPP provavelmente não lançaríamos estes empreendimentos, e mesmo que tivéssemos lançado, eles não teriam os preços de venda que alcançamos" ${ }^{\prime 62}$.

A operação no Complexo do Alemão em 2011 e toda espetacularização midiática que envolveu esse processo, também resultou numa aproximação do mercado imobiliário com a região. Na mesma entrevista, o presidente da Calçada afirma que como efeito da ocupação do Alemão, o bairro da Penha entrou no radar das incorporadoras através de novos estudos de aquisição de terrenos.

Franco (2014) alerta que, embora a instalação das UPPs seja vista como positiva para o mercado imobiliário, "para os moradores da favela significa uma alteração quase que insustentável em seu orçamento. (...) Fica patente que tal Política de Segurança apresenta como desdobramento uma remoção econômica à população com menor poder aquisitivo" 163 . Para a autora,

\footnotetext{
Quando se analisa o viés econômico e a alta dos preços nas favelas, observa-se que alguns estabelecimentos comerciais, por exemplo, fecharam as portas por não conseguirem arcar com as taxas decorrentes do processo de regularização. Aliado a isso, observou-se uma valorização de até $200 \%$ no preço dos imóveis, tanto para aluguel quanto para compra e venda, após a ocupação da favela pela Polícia Pacificadora (FRANCO, 214, p. 84)
}

O controle territorial das favelas do Rio pelo Estado é uma forma de viabilizar as garantias que o capital incorporador precisa para intensificar a mobilização da terra enquanto mercadoria imobiliária e, com isso, garantir o arcabouço jurídico necessário para regularização dessas propriedades.

\footnotetext{
162 Ibid.

${ }^{163}$ FRANCO, 2014, p. 84
} 
As imagens abaixo ilustram a localização das comunidades "pacificadas" do Rio de Janeiro e a taxa percentual de aumento dos preços dos imóveis no entorno de cada uma delas registrada pelo Secovi Rio para imóveis residenciais de dois quartos, antes e depois da ocupação em 2011. As demais, ilustram o discurso midiático entorno do processo das UPPs:

Figura 4. UPP na mídia

\section{Após UPPs, Tijuca recupera autoestima e volta a se valorizar}

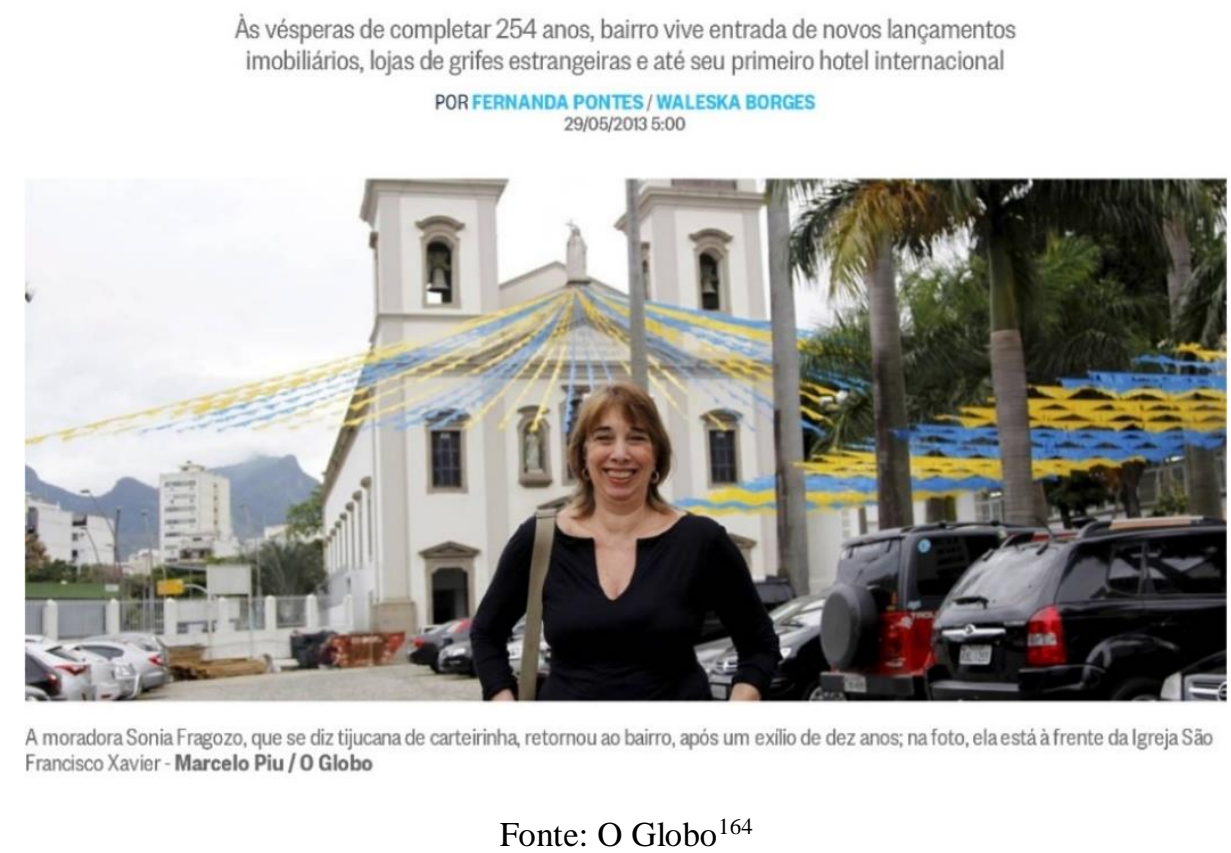

${ }^{164}$ http://www.upprj.com/index.php/acontece/acontece-selecionado/imoveis-em-areas-com-upp 
Figura 5. Localização das UPPs no município do Rio de Janeiro

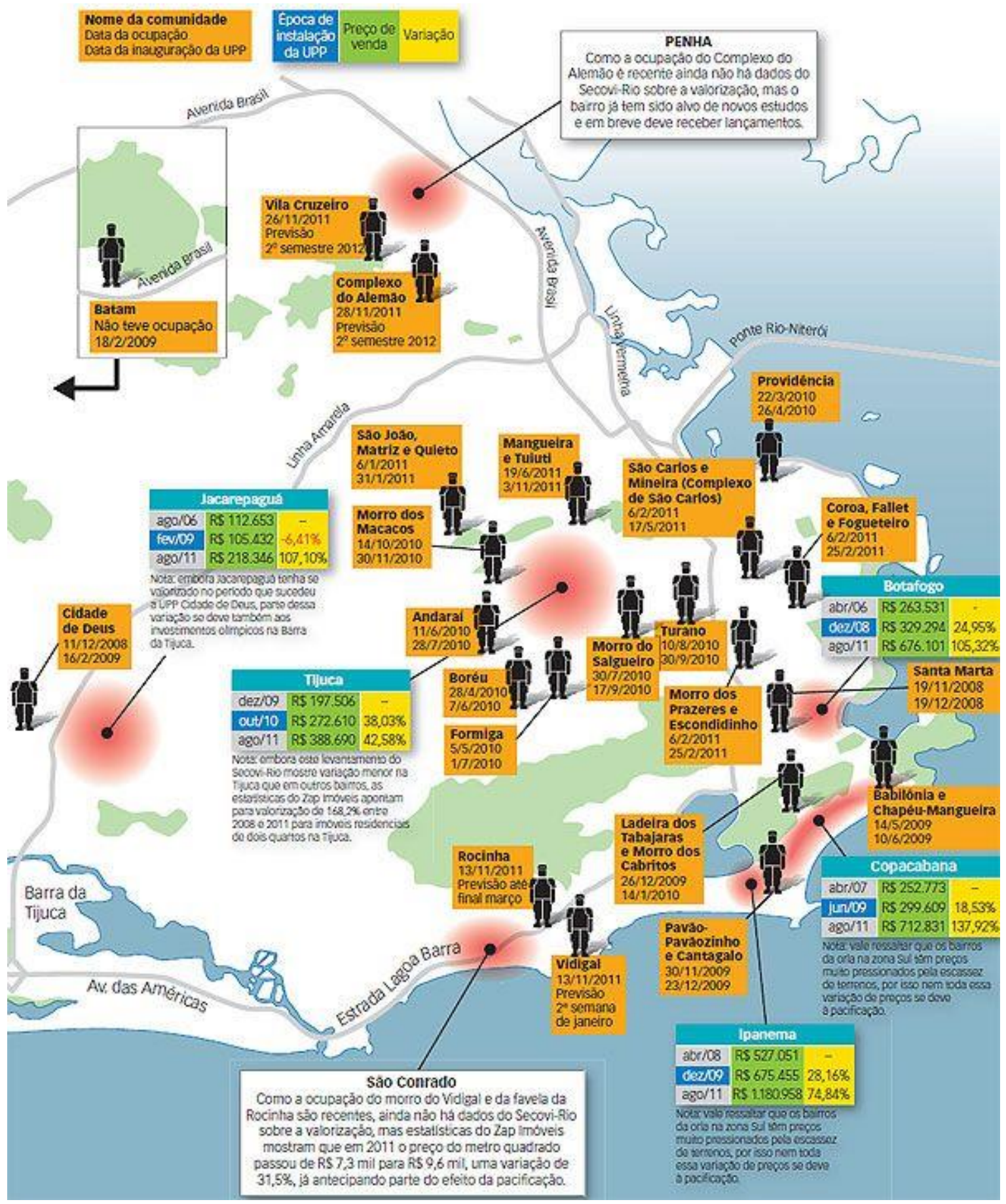

Fonte: Secovi Rio

***

Nesse cenário de recente expansão a partir de 2007 da produção imobiliária no Rio de Janeiro, impulsionada pelos fatores expostos acima, é incontestável o papel assumido pelo Estado em suas diferentes esferas na elaboração de um ambiente propício para a reprodução 
ampliada do capital a partir do imobiliário na produção do espaço carioca. Lefebvre ([1972] 2008) aponta que a mobilização do imobiliário tornou-se central para a sobrevivência do capitalismo, deixando de ser um simples agregado do capital industrial e financeiro e passando a ser protagonista na economia. Nesse sentido, a reestruturação territorial dirigida pelo Estado ajudou a construir novas fronteiras para a produção, circulação e consumo a partir das medidas adotadas em convergência com o capital incorporador e financeiro.

É importante ressaltar que a realização dessas medidas em âmbito local, contou com um poderoso discurso que utiliza dos megaeventos esportivos como chance única para alavancar a economia e dar uma cara nova à cidade a partir de uma falsa ideia, propagandeada a todo instante, de um cenário catastrófico de crise. Esse discurso ganhou força no senso comum, pois girava em torno de um suposto "imenso legado" que os Jogos Olímpicos deixariam para a cidade. Nesse sentido, Vainer (2000) aponta para uma estratégia discursiva calcada no modelo de planejamento estratégico ${ }^{165}$ de cidades fortemente difundido no Brasil e América Latina a partir dos anos 1970, mas que se estabelecera de fato apenas na década de 1990 e que segue até os dias atuais, em total consonância com o processo que descrevemos no primeiro capítulo. Um elemento fundamental dessas estruturas discursivas que tem como projeto a apropriação da cidade como meio privilegiado de reprodução do capital financeiro internacional, é o forjamento de consensos, no âmbito da ideologia, nos termos de Marx. Para Vainer, nada é

mais consistente e reiteradamente enfatizado (...) que a necessidade do consenso. Sem consenso não há qualquer possibilidade de estratégias vitoriosas. O plano estratégico supõe, exige, depende de que a cidade esteja unificada, toda, sem brechas, em torno ao projeto. Na verdade, esta condição está como que pressuposta desde o início, pois o discurso, a todo tempo, tratou a cidade como uma unidade: a cidade compete, a cidade deseja, a cidade necessita (VAINER, 2000, p. 91)

Para Castro (2015), os megaeventos foram "a expressão de um projeto urbano de reestruturação da cidade, e da adoção de um novo padrão de governança empreendedorista neoliberal, sustentada por uma coalizão de interesses econômicos, políticos e sociais"166. O capitalismo neoliberal que a priori se coloca enquanto antagonista ao Estado, com ferozes críticas ao seu funcionamento, exige, na prática, uma forma de gestão estatal que dê conta

\footnotetext{
${ }^{165}$ Nos estudos urbanos, o Planejamento Estratégico Urbano é um tipo de modelo de gestão de cidades que foi bastante difundida nos países latino-americanos a partir do receituário neoliberal por agências de cooperação e multilaterais, como o BID e o Banco Mundial, mas também por consultores privados internacionais, a partir do case Barcelona. Segundo Vainer (2000), trata-se da transposição para o espaço urbano dos conceitos e metodologias do planejamento estratégico empresarial, elaborados originalmente na Harvard Business School. ${ }^{166}$ CASTRO, 2015, pp. 11-12
} 
de continuar a garantir a condições gerais de acumulação, pois uma vez que as "intervenções públicas ficam subjugadas ao regime de acumulação privada e aos interesses de reprodução política e econômica dos agentes capitalistas, o planejamento urbano (ainda prerrogativa dos governos) serve à rentabilidade dos investimentos" ${ }^{\text {167 }}$. Nessa lógica, Lefebvre ainda destaca na obra há pouco citada que o "ordenamento territorial", objeto de manipulação dos tecnocratas subordinados ao Estado, corrobora os interesses privados de apropriação do espaço, em especial dos promotores imobiliários e bancos, servindo-se desses instrumentos como poderoso estímulo de acumulação. Mascaro (2013) sintetiza essa relação entre capital e Estado no atual contexto concluindo que

o neoliberalismo não é uma política dos capitais contra os Estados, é uma política dos capitais passando pelos Estados. (...) O favorecimento aos capitais especulativos em desfavor do planejamento da produção é uma política constante e sistemática dos Estados nacionais, num tenso concerto de movimentação internacional dos capitais (MASCARO, 2013, p.124)

É, portanto, no atual regime capitalista neoliberal, marcado pelo predomínio da esfera financeira como principal meio de acumulação de capital a partir dos juros e da renda - não perdendo de vista a importância estrutural da esfera produtiva - e que assume o comando da abertura de novas fronteiras de acumulação a partir da reestruturação do espaço, que o Estado também se reestrutura conformando seus arranjos jurídico-institucionais para continuar a ser o principal coordenador desse processo.

Ora, o que se percebe concretamente a partir da análise das múltiplas escalas e diversos arranjos dessa relação capital financeiro - incorporadoras nacionais - Estado, tanto no nível global quando no local, foi uma frenética expansão da produção imobiliária impulsionada pelo imbricamento das grandes incorporadoras com o mercado financeiro para espaços da cidade historicamente preteridos pelo setor imobiliário, mobilizando e dinamizando o mercado de terras de toda a cidade a partir do processo de capitalização da propriedade, ou seja, o deslocamento para o tempo presente de ganhos que poderão ser auferidos no futuro. Essa "dinamização" pode ser compreendida como um processo de intensificação da propriedade imobiliária como capital fictício, conforme já mencionado anteriormente. Nesse sentido, as ações estatais na constituição de mecanismos de capitalização, tanto de caráter jurídico-financeiro no âmbito global quanto socioespaciais em escala local, foram

${ }^{167}$ FAULHABER, 2015, p. 109 
fundamentais para assegurar os preços imobiliários alcançados na expansão das fronteiras de acumulação imobiliária para o subúrbio do Rio de Janeiro.

Além da transformação territorial, a elevação dos preços intensificou também um processo de segregação espacial, já que os altos preços praticados inviabilizaram a permanência de muitas famílias nesses espaços, provocando a migração das mesmas para lugares ainda mais precários dentro do espaço metropolitano. Conforme apontado por Lefebvre "o espaço é artificialmente rarefeito para 'valer' mais caro; ele é fragmentado, pulverizado, para a venda no atacado e no varejo. Ele é o meio das segregações" ${ }^{168}$. No interior de todo esse processo o que se percebe é a intensificação dos processos de espoliação imobiliária, tornando a vida dos trabalhadores cariocas cada vez mais precária, sob diversos aspectos. O mapa e tabela seguintes demonstram todo esse processo de considerável variação de preços imobiliários na cidade do Rio de Janeiro, em especial no subúrbio.

Mapa 6. Variação da taxa de valorização (\%) do preço dos imóveis no município do Rio de Janeiro por bairros entre 2008 e 2015

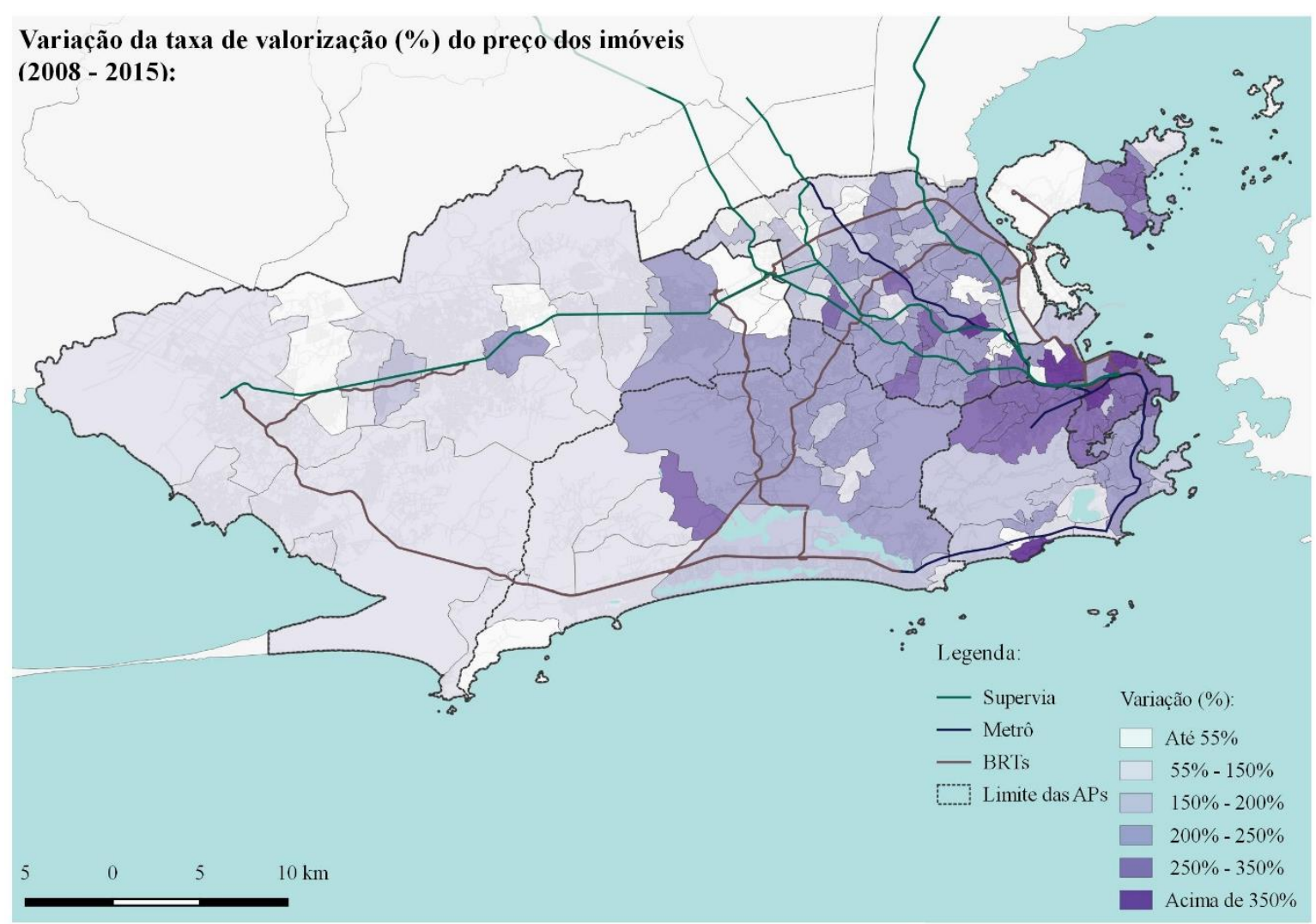

Fonte: elaboração própria com base em dados do Fipe-Zap através de consulta realizada em fev/2018

${ }^{168}$ LEFEBVRE, [1972] 2008, p. 125 
Tabela 6. Bairros com maiores variações da taxa de valorização 2008 e 2014

\begin{tabular}{|c|c|c|c|c|c|c|c|}
\hline \multicolumn{8}{|c|}{ Rio de Janeiro: valorização de imóveis por bairros* (2008 - 2014) } \\
\hline Posição & Bairro & Variação (\%) & Amostras & Posição & Bairro & Variação (\%) & Amostras \\
\hline 1 & Del Castilho & 386,4 & 240 & 21 & Cachambi & 229,7 & 999 \\
\hline 2 & S. Cristóvão & 370,1 & 196 & 22 & Botafogo & 228,6 & 2172 \\
\hline 3 & Pilares & 340 & 142 & 23 & Humaitá & 227,4 & 298 \\
\hline 4 & Rio Comprido & 339,7 & 415 & 24 & Piedade & 225,4 & 162 \\
\hline 5 & Santa Teresa & 319,1 & 258 & 25 & Irajá & 221,9 & 343 \\
\hline 6 & Andaraí & 317,9 & 336 & 26 & Penha & 218,3 & 150 \\
\hline 7 & Glória & 308 & 330 & 27 & Copacabana & 216,5 & 5074 \\
\hline 8 & Centro & 304,5 & 937 & 28 & Flamengo & 214,8 & 1861 \\
\hline 9 & Vl. Is abel & 293,9 & 1306 & 29 & Vista Alegre & 214,5 & 153 \\
\hline 10 & Riachuelo & 287,5 & 246 & 30 & Curicica & 210 & 235 \\
\hline 11 & Grajaú & 285,7 & 838 & 31 & Méier & 203,6 & 1431 \\
\hline 12 & Maracanã & 277,1 & 550 & 32 & Jacarepaguá & 200,9 & 851 \\
\hline 13 & Tijuca & 276,6 & 7101 & 33 & Olaria & 196,7 & 219 \\
\hline 14 & Lapa & 266,5 & 150 & 34 & Vl. Valqueire & 189,3 & 277 \\
\hline 15 & Eng. de Dentro & 244,1 & 565 & 35 & Jd. Guanabara & 188,9 & 573 \\
\hline 16 & Eng. Novo & 242,2 & 543 & 36 & S. Conrado & 186,6 & 281 \\
\hline 17 & Lins & 238,1 & 315 & 37 & Madureira & 181 & 203 \\
\hline 18 & Catete & 237,8 & 472 & 38 & Leme & 174,9 & 256 \\
\hline 19 & Laranjeiras & 236,8 & 1176 & 39 & Vl. da Penha & 165,8 & 531 \\
\hline 20 & Bonsucesso & 229,8 & 114 & 40 & Jd. Botânico & 159,9 & 156 \\
\hline
\end{tabular}

Bairros que compõem a Zona Norte do Rio de Janeiro

* Bairros com amostras consistentes e série histórica disponíveis no Fipe-Zap

Fonte: elaboração do autor com base em dados do Fipe-Zap através de consulta realizada em jul/2014 


\section{CAPÍTULO 03 |}

Reestruturação imobiliária e metropolização do espaço urbano carioca no século XXI: a intensificação dos processos de capitalização, centralização do capital e a expansão das fronteiras de acumulação 
A produção social do espaço se estabelece na atualidade brasileira com novos contornos e especificidades através do setor imobiliário, integrando-se ao mercado financeiro mundial de um lado e, de outro, com o Estado, como foi abordado no capítulo anterior. Neste capítulo abordaremos como na atual fase do capitalismo, cujo aspecto financeiro passa a ter grande relevância nas transformações da dinâmica do sistema a fim de garantir sua reprodução, reconfigura de maneira significativa o espaço das metrópoles contemporâneas à sua feição, pois encontra nele um impulso à sua sobrevida. Nessa lógica, o setor imobiliário se reestrutura e passa a ter um papel fundamental enquanto frente privilegiada de acumulação de capital. Torna-se então imperativo a compreensão das especificidades do desenvolvimento desse processo de reestruturação imobiliária que tem no domínio do capital financeiro, na metropolização do espaço e na centralização do capital no imobiliário suas características destacadas.

Nesse contexto, emerge como referência concreta de tais processos as transformações ocorridas na produção do espaço da cidade do Rio de Janeiro no século XXI, dando destaque à produção mais recente no subúrbio da Zona Norte. Tal abordagem será feita a partir do seguinte recorte: a produção das grandes incorporadoras que possuem relevância nacional e que, a partir de meados da década de 2000, abriram capital na Bolsa de Valores e passaram a ter uma atuação extremamente significativa em todo o território carioca.

Como traço característico dessa reestruturação que não só integra, mas intensifica a relação entre as dinâmicas imobiliária (socioespacial) e financeira (socioeconômica) no Brasil, podese destacar a consolidação das grandes incorporadoras-construtoras que passaram a ter uma atuação privilegiada no âmbito nacional, culminando numa acelerada expansão de novos empreendimentos, especialmente com o impulso dado pelo Programa Minha Casa Minha Vida, passando a atuar em espaços menos valorizados, periferias urbanas e até mesmo em espaços precários do ponto de vista da infraestrutura e equipamentos públicos, onde tradicionalmente o mercado imobiliário não atuava. Como aponta Rufino (2012), neste período específico, "identifica-se o movimento específico de fortalecimento da atuação de grandes grupos de incorporação articulados ao capital financeiro. Tal movimento de capitais dá relevo à forma incorporação e a convergência entre o financeiro e o imobiliário" ${ }^{169}$.

${ }^{169}$ RUFINO, 2012, p. 35 
$\mathrm{Na}$ atualidade, a produção desigual e diferencial do espaço nas cidades brasileiras se acentua a partir do momento em que o capital financeiro passa a ter um papel fundamental na produção desses espaços. Este processo desencadeou um aumento geral do preço da terra nas cidades brasileiras, intensificando processos espoliativos já expostos e, consequentemente, tornando mais cara a vida nas metrópoles. Segundo pesquisa realizada pela Fundação João Pinheiro, o déficit habitacional no município do Rio aumentou 10,5\% entre os anos de 2011 e 2012. Além disso, a cidade viu aumentar em 35\% o número de famílias de baixa renda que comprometem mais de $30 \%$ de seus rendimentos com aluguel entre 2007 e $2012^{170}$, tornando a cidade do Rio de Janeiro um caso bastante emblemático: entre os anos de 2008 e 2015, a cidade experimentou uma taxa de valorização média do preço dos imóveis de $360 \%$ em janeiro de 2015, com números acima da média nacional, sendo a capital brasileira com maior variação no período, como pode se constatar no gráfico a seguir:

Gráfico 7. Variação da taxa de valorização imobiliária por cidade (2008-2016)

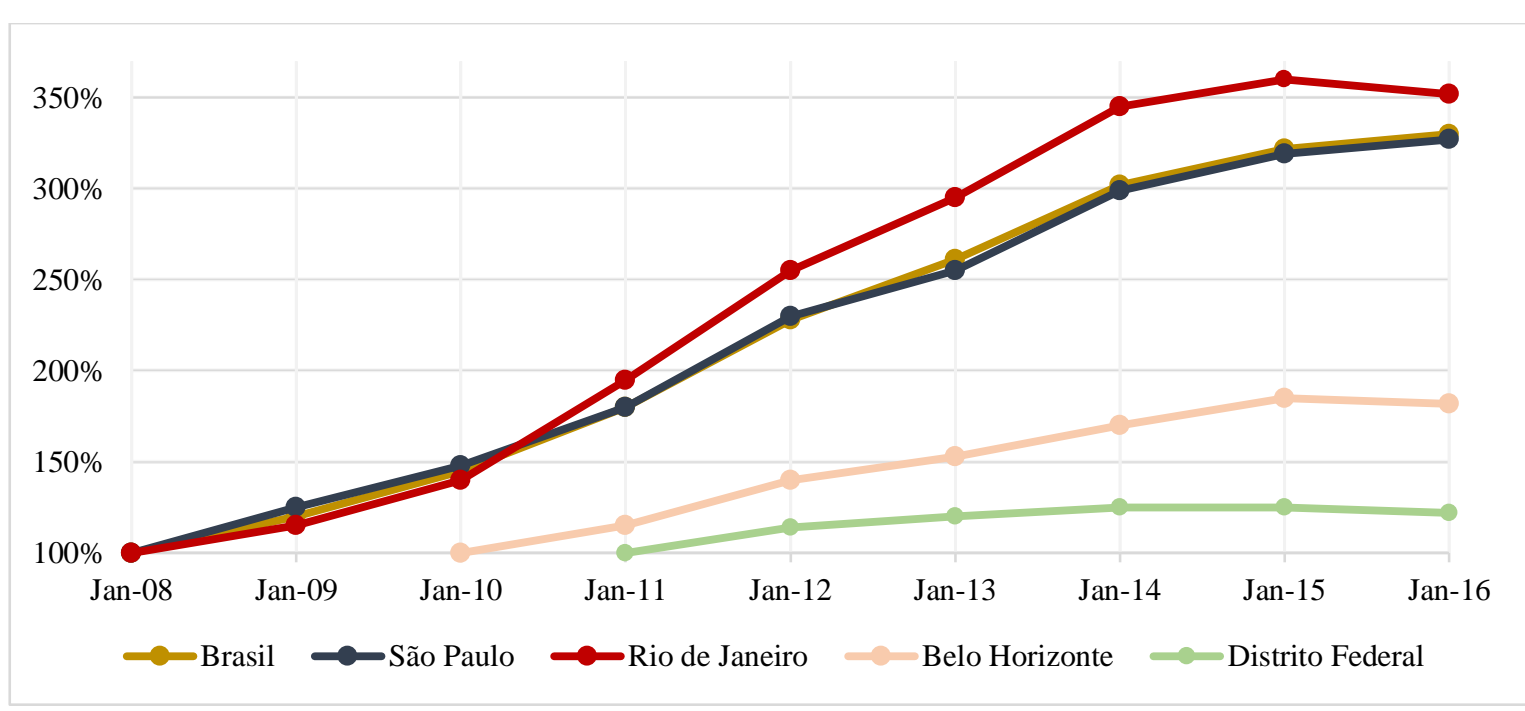

Fonte: Fipe

O cenário atual que reforça a institucionalização da hegemonia das finanças nos diferentes níveis de produção (imediato, global e total) torna mais intenso os processos de exploração do trabalho que, combinados aos processos de espoliação cada vez mais profundos, asseguram, sobretudo na esfera mundial, maior valorização do capital, consolidando a acumulação financeira e impulsionando os processos de concentração e centralização do

\footnotetext{
${ }^{170}$ https://www.bbc.com/portuguese/noticias/2014/05/140527_deficit_habitacional_ms
} 
capital. Desse regime resultam a concentração do poder econômico rentista e patrimonial e o aprofundamento das desigualdades sociais.

$\mathrm{Na}$ esteira desses processos, a capitalização das principais incorporadoras nacionais via mercado de ações na Bolsa, desencadeou uma série de processos típicos de centralização do capital, como a aquisição e fusão de empresas. A centralização do capital é, em síntese, um processo inexorável do modo de produção capitalista de concorrência entre capitais onde um capitalista é expropriado pelo outro. Segundo Lencioni (2017), esse processo desencadeia uma reorganização dos ciclos de valorização dos capitais que se apresentam fracionados, havendo uma redução do número de empresas que atuam no mercado, acirrando, assim, os patamares de concorrência ${ }^{171}$. Para Aglietta,

enquanto a concentração simples é, dentro do campo do valor, um fato quantitativo de acumulação desigual que conserva a autonomia dos capitais, a centralização é uma modificação qualitativa que remodela a autonomia dos capitais e cria novas relações de concorrência. É um processo descontínuo no tempo, relacionado com as fases de formação do capital no processo de acumulação global, que se produz simultaneamente no conjunto da economia e cujos efeitos são irreversíveis. Com a centralização do capital desaparecem inúmeros capitais individuais por absorção, enquanto outros são reagrupados por fusão ou consolidação (AGLIETTA, 1986, p. 195, grifos do autor)

Gráfico 8. Fusões e aquisições no Brasil (1985-2015)

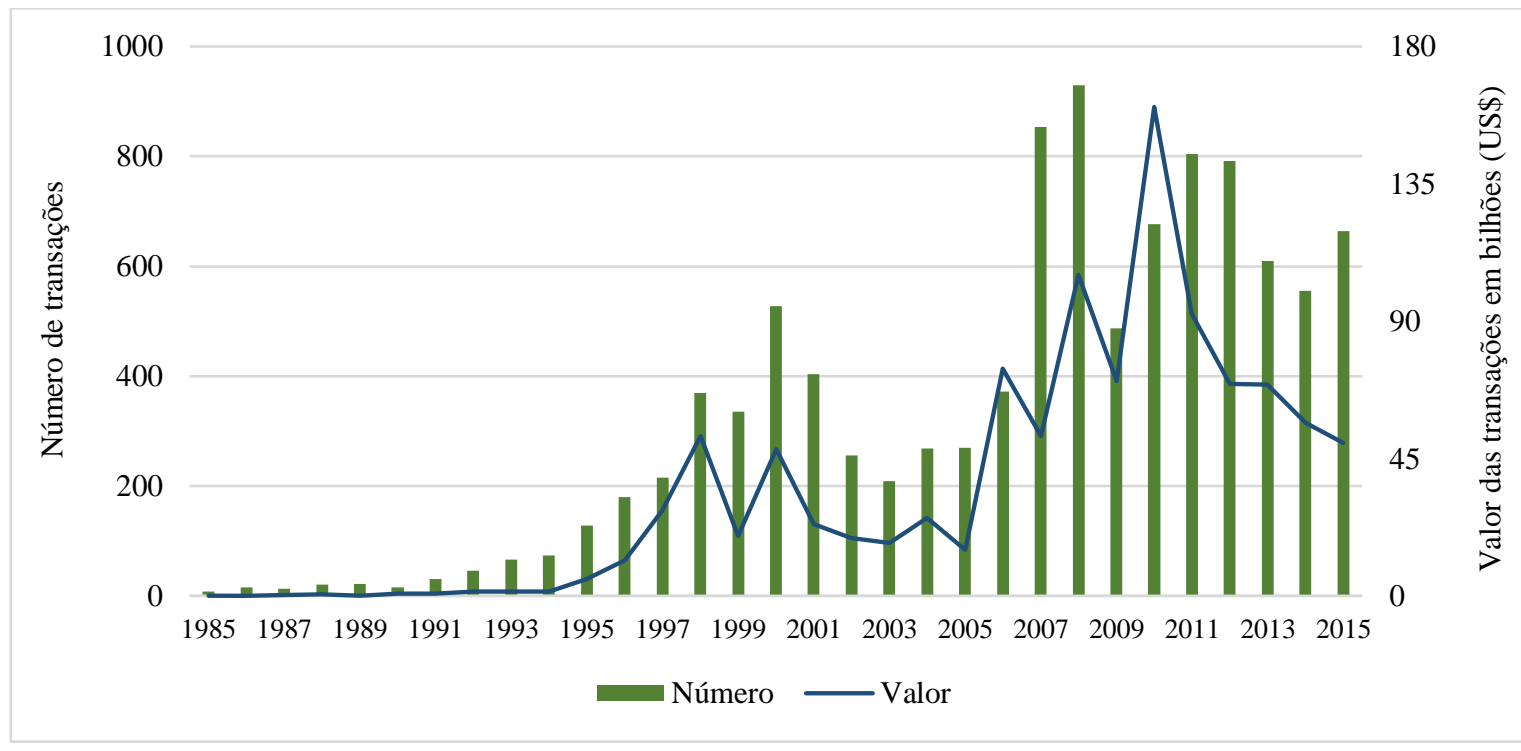

Fonte: Institute of Mergers, Acquisitions and Alliances (IMAA) ${ }^{172}$

${ }^{171}$ LENCIONI, 2017, p. 115-117

$172 \mathrm{https} / / /$ imaa-institute.org/m-and-a-statistics-countries/ 
O gráfico anterior mostra as operações de fusão e aquisição entre empresas no Brasil no intervalo dos anos de 1985 e 2015, sejam oriundos de capitais nacional ou internacional. É explícito que a partir de 2006 há um aumento expressivo do número desse tipo de transação, bem como dos valores envolvidos em cada uma delas.

No caso do setor imobiliário, esses processos foram fundamentais para que essas empresas pudessem atuar fora do seu know-how de origem, uma vez que a maioria das grandes empresas estavam historicamente envolvidas na incorporação de empreendimentos para o segmento de alto padrão e em áreas específicas, sobretudo no eixo Rio-São Paulo. Esse processo favoreceu a expansão da produção dessas empresas para outros territórios, até então dominados por incorporadoras-construtoras locais, mas também para os segmentos econômicos voltados para faixas de renda mais populares, o que requer estratégias distintas, seja de atuação, seja de tipos de produto e até nova inserção territorial. Em relação aos dados sobre fusões e aquisições no setor imobiliário brasileiro elaborados por Lencioni (2017), entre 2008 e 2011, foram realizadas 116 transações desse tipo, destacando-se como um dos setores onde mais se realizou tal operação no país ${ }^{173}$.

Embora esse processo onde uma empresa adquire outra, se fundem e até mesmo se associam marque uma estratégia de diversificação dos negócios pelas incorporadoras, "elas, de modo algum, abandonam suas atividades voltadas a atender os estratos superiores de renda da sociedade, ou seja, as grandes incorporadoras seguem produzindo também para o mercado residencial em áreas mais valorizadas" ${ }^{174}$. Nesse contexto, tal observação é importante para advertir que durante o período de expansão do setor, sobretudo com o considerável reforço dado pelo PMCMV e a expansão da produção habitacional de mercado para áreas menos valorizadas, as áreas ditas mais nobres das cidades brasileiras também experimentaram um forte incremento de novos lançamentos imobiliários. Pode-se afirmar então que houve uma explosão de lançamentos imobiliários de mercado para diversos segmentos de renda em toda a cidade, algo nunca realizado nessas proporções. Com isso, uma das estratégias adotadas pelas grandes incorporadoras foi aderir à marca de empresas subsidiárias para cada tipo de produto como forma de preservar a marca principal. No Rio de Janeiro, por exemplo, a Cyrela e a Gafisa, empresas tradicionais na incorporação e construção de empreendimentos

\footnotetext{
${ }^{173}$ Ibid., p. 121

${ }^{174}$ VOLOCHKO, 2015b, p. 104
} 
de alto padrão, quando no lançamento de novos empreendimentos para os segmentos econômico e médio, usam as marcas Living e Tenda ${ }^{175}$, respectivamente.

Do ponto de vista das múltiplas escalas em que esse processo se revela, Rufino (2012) salienta que a incorporação, ainda que consolidada nos diversos contextos nacionais, "relaciona-se com as caraterísticas estruturais do capitalismo, que na atualidade são marcadas pelo domínio do capital financeiro mundializado. Sua grande mobilidade favorece a confluência para o setor imobiliário, reconhecido como lócus de reprodução privilegiada"176 do capital. A autora manifesta que

\begin{abstract}
o resultado das estratégias de 'diversificação dos segmentos' e 'expansão geográfica', diretamente associados à abertura de capital e à recuperação dos financiamentos, é o alcance de um outro patamar de lucratividade por essas empresas, que ganham expressão internacional. De acordo com ranking da consultoria Economatica, no terceiro trimestre de 2009, estavam no Brasil 12 das 20 construtoras de capital aberto mais lucrativas da América Latina e Estados Unidos. Outra notícia, do Jornal Valor Econômico, mostra ainda que enquanto em 2006 apenas uma única empresa do setor possuía faturamento acima de um bilhão de reais, em 2009, oito companhias passaram a figurar nesse mesmo patamar" (RUFINO, 2012, pp. 76-77)
\end{abstract}

Nesta reconfiguração marcada pela integração do mercado financeiro com o imobiliário, o espaço tornou-se um campo privilegiado para a generalização e intensificação da formacondomínio que, segundo Pereira (2013), "se difundiu como se fosse uma forma arquitetônica, mas a rigor é uma forma de propriedade do imóvel"177. Segundo o autor,

\begin{abstract}
a intensificação desse tipo de negócio imobiliário, a produção massiva de condomínios para os mais variados usos dá origem aos complexos imobiliários-urbanísticos que alteram o volume dos projetos e dos investimentos. Esses megaprojetos direcionam a transformação socioespacial não só porque negam o espaço público e o uso urbano da cidade, mas porque aceleram a reconfiguração da cidade como mercadoria imobiliária (PEREIRA, 2013, p. 98)
\end{abstract}

O espaço então torna-se essencial na lógica de acumulação capitalista e financeira, imbricando o imobiliário com o financeiro para potencializar seus rendimentos. Para Lefebvre (2008), o imobiliário mobilizado tornou-se central no capitalismo. O autor argumenta que este setor é privilegiado, pois "a construção proporcionou e ainda proporciona lucros superiores à média. A especulação não entra nesse cálculo, mas

\footnotetext{
175 Gafisa e Tenda se dissociaram em 2017.

176 RUFINO, 2012, pp.41-42

177 PEREIRA, 2013, p. 98
} 
superpõe-se a ele; nela e por ela, através de uma mediação - o espaço - o dinheiro produz dinheiro" $" 178$.

Essa reconfiguração que intensifica a produção do espaço como mercadoria imobiliária é analisada por Pereira (2013) e Lencioni (2017) à luz do conceito de Reestruturação Imobiliária. A autora expõe que esse processo de reestruturação é marcado por processos fundamentais que se intensificam nas cidades contemporâneas como "a densificação das construções nas áreas mais centrais da metrópole e a dispersão do espaço construído que produz uma metrópole contemporânea difusa" ${ }^{179}$. De maneira mais abrangente,

\begin{abstract}
a noção de reestruturação imobiliária é, inicialmente, uma percepção da dinâmica imobiliária, um entendimento da especificidade das formas de propriedade do imóvel urbano, do edifício e da terra. Por isso, se fundamenta na valorização imobiliária e na renda da terra, que altera seu ritmo quando se associa ao nível global da acumulação. Em seguida, a estruturação é um imbricamento da dimensão social e da dimensão espacial gerando uma unidade por onde de observa o filtro da dinâmica imobiliária e a hierarquia das formas de produção do espaço que toma relevo nos processos socioespaciais da atual relação espaço-tempo. (PEREIRA, 2013, p. 100)
\end{abstract}

Pereira (2013) ainda aponta em seu texto que a noção desse conceito é uma forma de abordar a cidade para além de sua transformação física, compreendendo as múltiplas escalas que envolvem essa mudança - do global ao local, do geral ao particular -, mas também os aspectos sociais imbricados aos espaciais. No nível mais concreto, observa-se as transformações na forma de produção do espaço, além das mudanças de caráter formal dos produtos imobiliários, que tem nos grandes condomínios dispersos pelas cidades integrados a formas mais "atrasadas" de produção, a manifestação mais acabada desse processo. A forma-condomínio então se renova "nesta nova etapa a partir de diferentes tipologias e em diversas áreas das cidades, destacando-se na paisagem por sua escala e pela ruptura com as estruturas urbanas precedentes" $" 180$.

No Rio de Janeiro essa reestruturação fica bastante evidente a partir de 2007, quando esses grandes empreendimentos imobiliários residenciais passam a fazer parte da paisagem carioca como um todo, não apenas em áreas mais valorizadas como a Barra da Tijuca, mas consolidando novas fronteiras de acumulação em direção ao subúrbio da cidade,

\footnotetext{
${ }^{178}$ LEFEBVRE, [1972] 2008, p.118

${ }^{179}$ LENCIONI, 2017, p. 110

${ }^{180}$ RUFINO, 2013, p. 145
} 
Mapa 7. Empreendimentos lançados no município do Rio de Janeiro entre 2000 e 2006: porte e preço

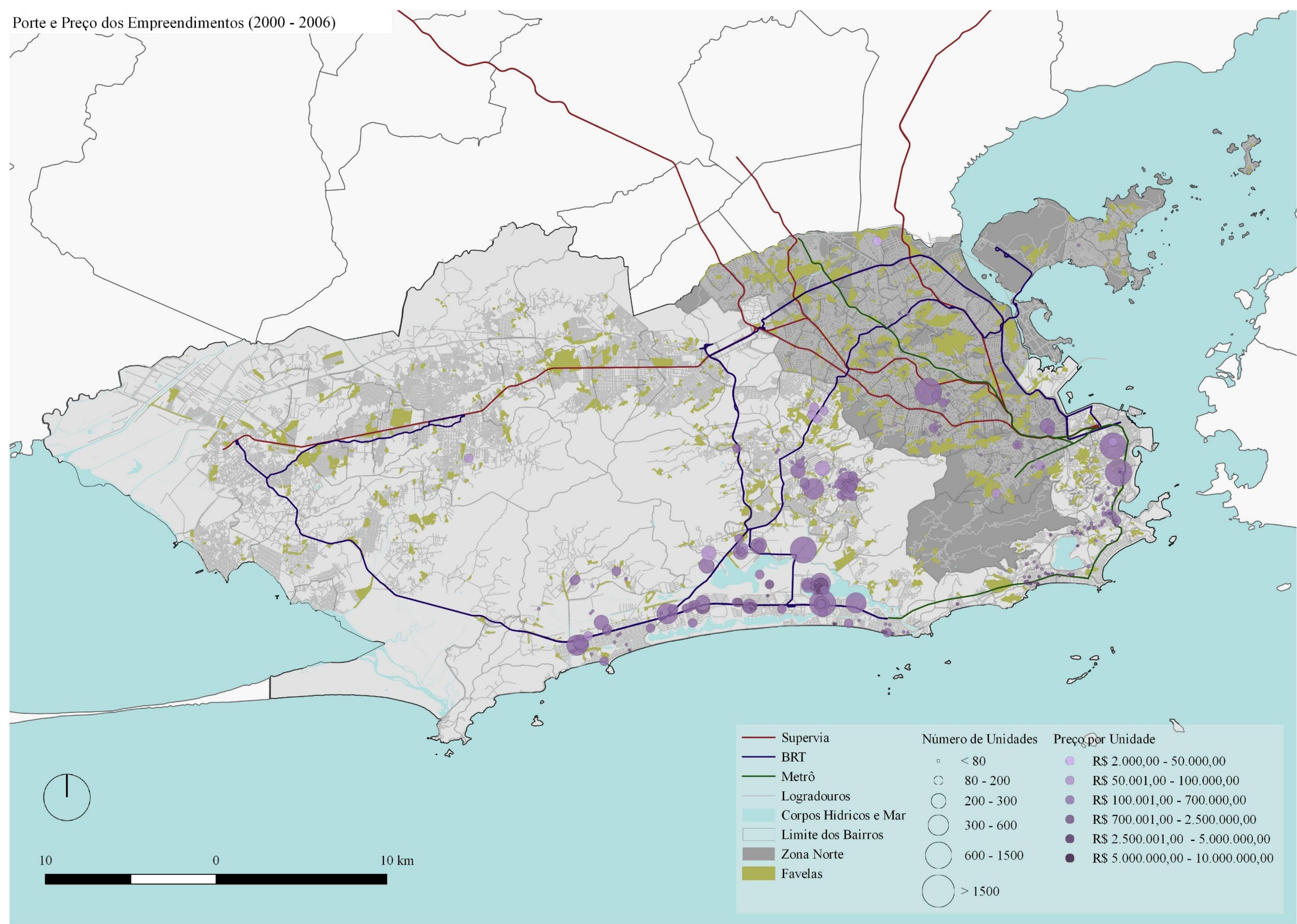

Fonte: elaboração do autor em parceria com Paula C. Moreira a partir de dados da Ademi 
Mapa 8. Empreendimentos lançados no município do Rio de Janeiro entre 2007 e 2015: porte e preço

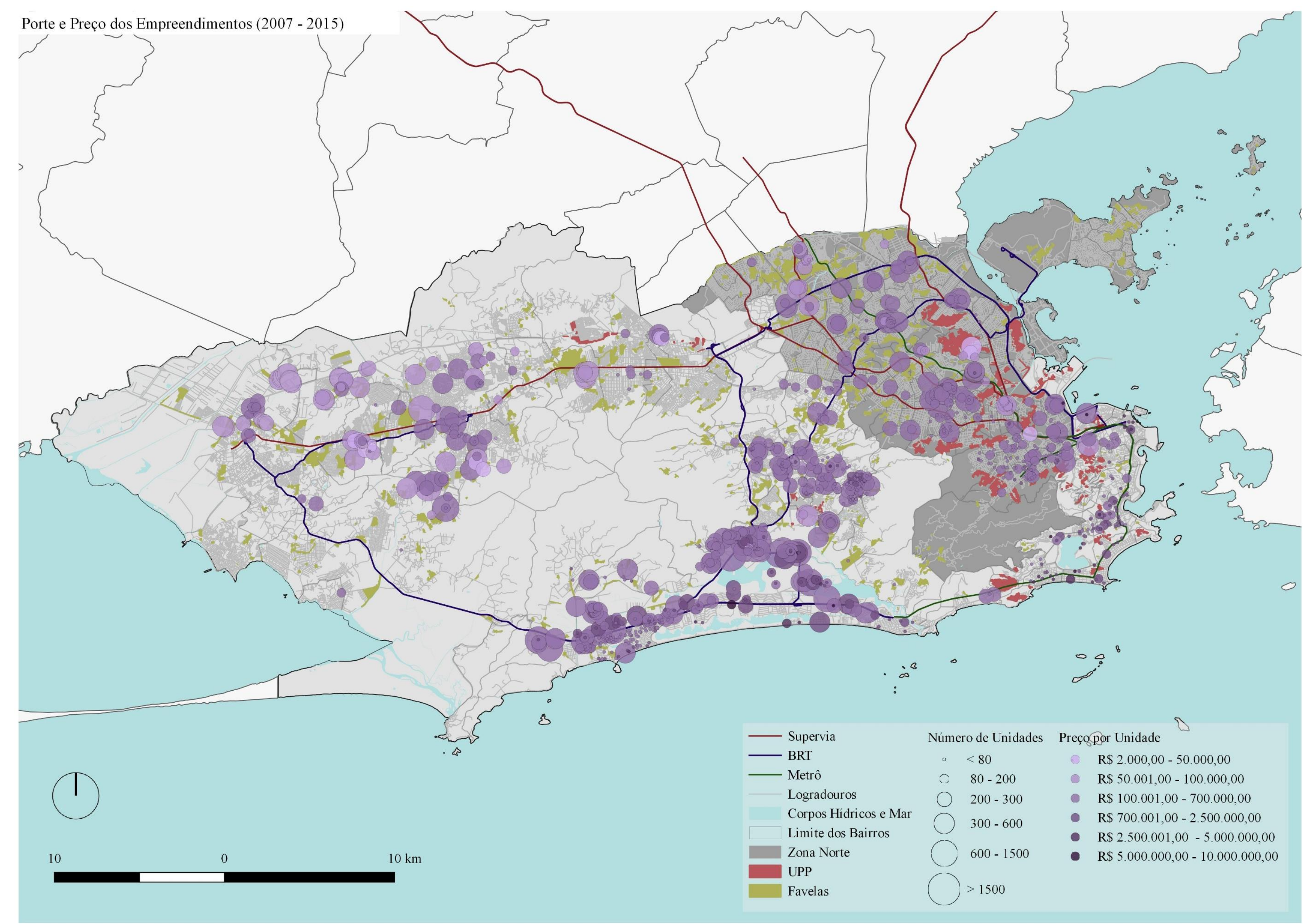

Fonte: elaboração do autor em parceria com Paula C. Moreira a partir de dados da Ademi 
apropriando-se de grandes terrenos ociosos de resquícios industriais em diversos espaços da cidade, inserindo-se, assim, de forma seletiva e fragmentada na metrópole, deixando bem marcada as diferenciações espaciais na escala local, consolidando-se como forma predominante da produção imobiliária e de expansão da metrópole. "A consagração dessa forma de propriedade dá relevo à forma intensiva de produção do espaço na totalidade da metrópole, iluminando uma nova lógica de produção do espaço que se diferencia da urbanização" ${ }^{" 181}$.

Tal diferenciação apontada por Rufino não tem, nas metrópoles contemporâneas, pelo menos como característica predominante, aquela expansão urbana que se consolidou ao longo do século XX: camadas sucessivas de urbanização extensiva cada vez mais distantes da centralidade onde se concentra os centros de decisão econômicos e políticos e também os empregos; horizontalizada e majoritariamente ocupada pela população mais pauperizada; marcada como lugar de reprodução da força de trabalho. Trata-se, portanto, de transição para um novo momento.

Essa atual conjuntura pode ser compreendida como fenômeno de metropolização do espaço que se constitui enquanto processo socioespacial que reconfigura o território e que está intimamente associado ao processo de globalização, onde o espaço social está subordinado a "uma dinâmica de expansão crescente das relações sociais capitalistas em escala planetária e, ao mesmo tempo, de intensificação dessas relações" ${ }^{182}$.

Lencioni (2013) aponta que essas transformações, além de não se restringirem às áreas metropolitanas institucionalizadas como tal, possuem uma dimensão cultural evidente, desenvolvendo-se nas múltiplas escalas territoriais - do local ao global - contribuindo para uma produção do espaço metropolitano difusa e dispersa. Com relação às transformações mais concretas na dimensão espacial, mais especificamente ao imobiliário, a autora ainda destaca que

\footnotetext{
a dinâmica do processo de metropolização vai envolvendo áreas e modificando o mercado de terras, que passa, assim, por uma maior "valorização", ou seja, por um aumento de seu preço. Em outros termos, há uma elevação geral do preço da terra, pois a propriedade privada da terra se constitui numa relação indispensável à produção imobiliária formal, que (não exclusivamente) mercantiliza o espaço. Em geral, as terras mais longe do núcleo metropolitano tendem a ter um preço de mercado menor. Por isso, devido a essa dinâmica dos preços, novas áreas passam a ser
}

\footnotetext{
${ }^{181}$ Ibid., p. 146

182 LENCIONI, 2013, p. 17
} 
continuadamente incorporadas à lógica do mercado de terras da metrópole, contribuindo para a indefinição dos limites do aglomerado metropolitano (LENCIONI, 2013, pp. 26-27)

Nesse contexto, o espaço suburbano se apresenta como uma nova fronteira de acumulação capitalista pelo imobiliário. Essa região que tradicionalmente esteve fora dos radares das incorporadoras, embora bem assistida do ponto de vista das infraestruturas de saneamento e mobilidade, passa a ser mobilizada lucrativamente, tornando-se um lugar privilegiado para reprodução desse capital. Com isso, como veremos mais detalhadamente adiante, as grandes incorporadoras atuam inicialmente nesse território a partir da compra de terrenos para realização de seus empreendimentos. Normalmente são terrenos de grandes dimensões, para construção de grandes empreendimentos, para que se possa garantir a rentabilidade esperada pelos investidores financeiros que ali aplicaram seus capitais através das incorporadoras. Esses terrenos possibilitam a construção de uma quantidade considerável de unidades habitacionais para diversos estratos sociais, dependendo da localização, além de seus preços serem, normalmente, menores que em áreas mais valorizadas, como a Zona Sul ou Barra.

Na base desse pensamento, segundo Volochko (2015a), “está a ideia de que a reprodução do capitalismo necessariamente se nutre de diferenciações entre países, regiões e mesmo no interior de uma metrópole para realizar uma acumulação sempre ampliada do capital" 183 . Isso quer dizer que as novas produções do espaço "representam momentos nos quais os capitais podem encontrar formas mais rentáveis de aplicação, podendo realizar novas valorizações, sobretudo diante das crises, migrando de um setor ou ramo da economia para outro que se apresente mais vantajoso" 184 . No que concerne a este ponto, o autor reforça que,

\begin{abstract}
dadas às necessidades de continuidade de produção ampliada da acumulação urbana, e dadas algumas barreiras como a raridade do espaço em certas regiões valorizadas e densamente ocupadas das cidades e metrópoles, o setor imobiliário de ponta e o capital financeiro, com o auxílio do Estado, passam atualmente a investir pesadamente na produção habitacional nos espaços periféricos - mas não apenas aí -, onde a pobreza historicamente constituída vem sendo mobilizada lucrativamente (VOLOCHKO, 2015a, p.112)
\end{abstract}

No limite, o que se percebe é que o impacto gerado na produção do espaço das cidades por essa reestruturação, que tem no imbricamento do financeiro com o imobiliário a condução desse processo, é uma radical homogeneização, fragmentação e hierarquização do espaço urbano: a) homogêneo, pois essa produção é marcada por uma forma monótona expressa em

\footnotetext{
${ }^{183}$ VOLOCHKO, 2015a, p. 111

${ }^{184}$ Ibid., p. 112
} 
todos os lugares. Na esfera da atual produção imobiliária residencial, seja no Rio de Janeiro, em Curitiba, Recife ou Goiânia, a paisagem passa a ser vista com uma certa monotonia, ou seja, um mais do mesmo no que diz respeito às formas e tipologias arquitetônicas. No caso dos edifícios corporativos, essa similaridade ainda é mais evidente e "mundializada" por assim dizer, pois essa mesmice arquitetônica se intensifica em escala global. Muñoz (2008) aposta no termo urbanalización para sintetizar este processo de "padronização" e "globalização" da paisagem. Ainda que pontuais, essas transformações são profundamente homogêneas, "porque não se desvinculam de funções que servem principalmente ao

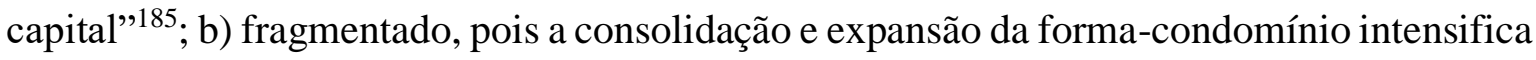
a segregação socioespacial, impondo-se sobre o território sem nenhum tipo de mediação com seu entorno imediato. "Esses territórios revelam com nitidez as diversas temporalidades: a dos condomínios privados, a das favelas, a das pequenas cidades, a dos centros de negócios" ${ }^{186}$, fazendo valer de determinadas localidades privilegiadas dentro do espaço metropolitano para se impor enquanto lugar privilegiado de acumulação capitalista pela diferenciação contínua da propriedade; e c) hierarquizado, pois o espaço, uma vez homogeneizado e fragmentando, nutre uma diferenciação espacial que cria uma hierarquia entre os lugares, tanto numa escala mais imediata, do local, quanto metropolitana, uma vez que o fortalecimento de novas centralidades altera a dinâmica socioespacial na metrópole, reestruturando as relações de subordinação econômica e política. No Rio de Janeiro, esse processo pode ser analisado à luz da expansão da produção de grandes condomínios privados para as áreas mais periféricas da cidade - o subúrbio carioca. -, onde se intensifica a produção desigual desse espaço da cidade.

Cabe aqui fazer uma advertência importante: ainda que no decorrer do capítulo tal questão se mostrará incontestável, não se pode afirmar que a produção imobiliária recente da cidade do Rio de Janeiro se constitui como forma de produção homogênea, ou seja, produzida apenas pelas incorporadoras que abriram capital na Bolsa - embora seja explícita a relevância delas na produção do espaço carioca. Tampouco se pode afirmar que toda essa produção é "financeirizada". Antes pelo contrário: as formas de produção do espaço observada nas pesquisas empíricas aqui expostas revelam-se heterogêneas, até mesmo quando se trata da forma incorporação. Contudo, optou-se como objeto de pesquisa a

\footnotetext{
185 PEREIRA, 2013, p. 105
}

${ }^{186}$ LENCIONI, 2013, p. 30 
compreensão dessa forma de produção que tem como característica essencial o fato dessas grandes empresas terem se capitalizado via mercado de ações - mais avançada e sofisticada do ponto de vista da acumulação capitalista - que se impõe sobre as outras sem superá-las, transformando o próprio setor e o urbano. O porte "grande empresa" aqui, é importante frisar, tem uma conotação genérica. Diz respeito apenas ao tamanho dessas empresas, no que diz respeito à capacidade de produção em grande escala, seja em relação ao volume de capitais que ela mobiliza, seja pela capacidade que elas têm de produzir diversos empreendimentos de grande porte.

Assim sendo, abordaremos na sequência a trajetória e as estratégias de atuação das três principais incorporadoras de capital aberto - Cyrela, MRV e PDG - no território da Zona Norte suburbana. A partir da análise crítica da produção dessas incorporadoras, será possível compreender o impacto de transformações descrito anteriormente no nível mais imediato, bem como a intensificação dos processos de homogeneização, fragmentação e hierarquização do espaço decorrentes da generalização da forma-condomínio na reestruturação do espaço metropolitano carioca.

\subsection{As estratégias de atuação das grandes incorporadoras de capital aberto no Rio de Janeiro}

Conforme descrito anteriormente, no período entre 2005 e 2007 ocorreram importantes mudanças no mercado imobiliário brasileiro a partir da adesão por parte das principais incorporadoras nacionais ao Novo Mercado da bolsa de valores. Essas mudanças acarretaram também numa profunda transformação socioespacial das principais metrópoles brasileiras. Neste subitem serão abordadas as estratégias de atuação de algumas dessas principais incorporadoras nacionais no território carioca, dando especial destaque à atuação das mesmas na Zona Norte suburbana da cidade. A escolha por analisar três incorporadoras de capital aberto - PDG, Cyrela e MRV - devem-se aos seguintes motivos: i) por serem incorporadoras de relevância nacional, tendo em vista seus respectivos volumes de produção, além da diversificação geográfica e de produtos imobiliários empreendidas por elas no período estudado; ii) pelas diferentes estruturas acionárias e estratégias de atuação no território de cada uma delas; iii) pelo volume de produção e atuação na área estudada e no restante da cidade. O que se busca enquanto análise desses casos é compreender como a 
concentração e a centralização de capital e as diferentes estruturas acionárias dessas incorporadoras influenciaram suas estratégias de atuação no território carioca e nas estratégias de diversificação dos produtos, tendo um impacto decisivo na produção do espaço da cidade e mais ainda na área em questão. Além disso, busca-se compreender como essas empresas, que tiveram uma ascensão meteórica a partir da segunda metade da década passada, passam, em pouco tempo, a enfrentar graves crises financeiras em alguns casos e, em outros, um arrefecimento de uma produção que se mostrava pujante, questionando a sustentabilidade de um modelo calcado na captura de capitais via mercado financeiro e as próprias contradições desse sistema que tem na capitalização via propriedade da terra e dos imóveis o seu fundamento. No entanto, antes de adentrarmos nesses temas, torna-se necessário contextualizar o mercado imobiliário carioca a partir dos anos 2000.

A conjuntura do mercado imobiliário carioca na virada para o século XXI segue a mesma tendência de baixa produtividade característica das décadas de 1980 e 1990 . Segundo dados da Ademi, embora o ano 2000 tenha apresentado uma reação em relação aos seus antecessores, quando foram lançados mais de 6mil unidades residenciais, nos dois anos seguintes (2001 e 2002), os números de lançamentos retornam a patamares registrados no início da década de 1990. Contudo, já em 2003 com o cenário macroeconômico nacional se estabilizando, o mercado mostra uma importante reação atingindo quase o dobro de lançamentos de 2002. O que se vê a partir disso é um contínuo reaquecimento do mercado na cidade confirmados pelos números de lançamentos dos anos posteriores, como demonstrado no gráfico seguinte.

Gráfico 9. Unidades residenciais lançadas na cidade do Rio de Janeiro (1980- 2006)

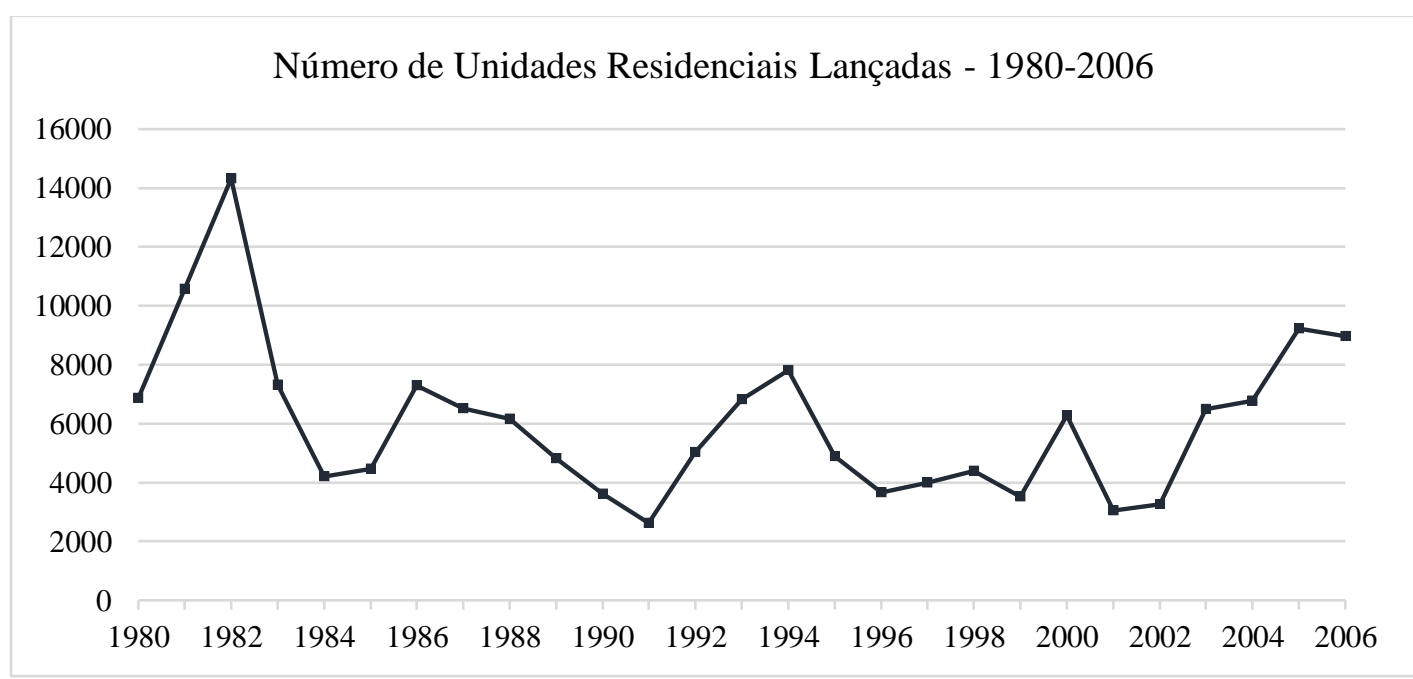

Fonte: elaboração própria com base em dados da Ademi e Compans (2002) 
No período que compreende os anos de 2000 a 2006, duas questões saltam aos olhos: em primeiro lugar pode-se dizer que $57 \%$ dos lançamentos neste período foram realizados entre 2005 e 2006, quando algumas incorporadoras já haviam aberto seus capitais na bolsa de valores. A outra questão importante a ser salientada é a primazia da Barra da Tijuca ainda como frente de expansão imobiliária na cidade, algo que se iniciara na década de 1970, devido ao grande estoque de terrenos ainda por se realizar e por uma legislação edilícia que permitia a produção de grandes empreendimentos imobiliários e a construção em altura bastante superior a outras regiões do município. Em estudo realizado por Compans (2002) para a SMU, observa-se que nos anos de 2000 e 2001, a área total licenciada para construção na Barra foi responsável por cerca de $24 \%$ do total no município do Rio, revelando uma grande concentração da atividade imobiliária no bairro. Essa concentração se confirma ainda através dos dados da Ademi, onde a Barra foi responsável por cerca de $32 \%$ de todos os empreendimentos lançados no período analisado. Se levarmos em consideração toda a AP 4, que envolve, além da Barra da Tijuca, todos os bairros da baixada de Jacarepaguá, as Vargens e o Recreio dos Bandeirantes, esse percentual salta para $73 \%$ de toda a produção imobiliária do período na cidade.

Gráfico 10. Participação do número de unidades lançadas na cidade do Rio de Janeiro por Área de Planejamento entre 2000 e 2006

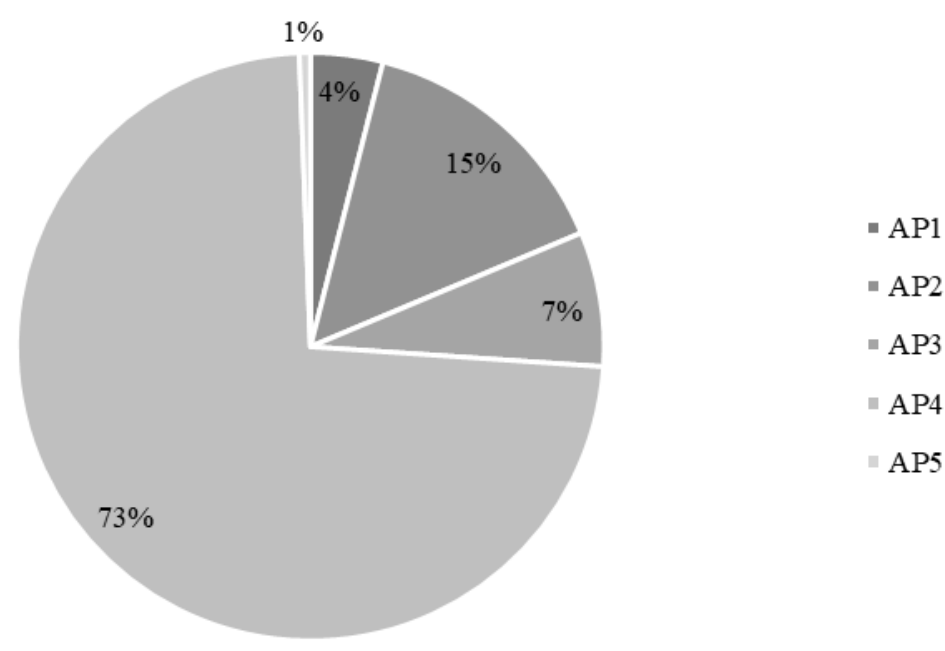

Fonte: elaboração própria com base em dados da Ademi

O estudo de Compans também destaca a considerável quantidade de empreendimentos de grande escala lançados na Barra da Tijuca no início da primeira década do século XXI. A pesquisadora revela que $76 \%$ da área licenciada no período para a Barra correspondia a 
empreendimentos com mais de $10 \mathrm{mil} \mathrm{m}^{2}$, o que exprime a predominância de grandes condomínios e se confirma a partir da observação da realidade.

A Zona Sul, que desde a década de 1970 vem esgotando-se como uma potencial região para novos lançamentos de mercado devido à sua quase saturação, legislação mais rígidas e altos preços dos terrenos, correspondeu, no período estudado, a $12 \%$ dos novos lançamentos. Contudo, a média de unidades por empreendimento não chega a quarenta, ainda que o empreendimento Quartier Carioca da PDG no bairro do Catete impressione pelas suas 880 unidades. Apesar desse esgotamento da região, a Zona Sul ainda se mostrava como uma saída para alcançar a alta rentabilidade por empreendimento para os promotores imobiliários pois o baixo número de unidades era e ainda é compensado pelo preço altamente elevado das mesmas. Completando a AP 2, os empreendimentos lançados na grande Tijuca - região que passou a se tornar relevante após o início do esgotamento da Zona Sul como frente de expansão imobiliária - corresponderam a módicos 3\% do total de lançamentos em toda a cidade.

Já a área compreendida como AP3, que agrega os bairros da Zona Norte suburbana, foi responsável por 7,43\% das unidades lançadas no período. Embora este percentual possa parecer modesto num primeiro momento, ele representa um considerável avanço dado os números de períodos anteriores, sinalizando o devir de expansão da fronteira imobiliária que se confirmaria poucos anos depois. No período entre 2000 e 2006, 86\% desses empreendimentos se concentraram na região do grande Méier, região do subúrbio que desde o final da década de 1970 já vinha alterando seu padrão de uso e ocupação do solo através da intensificação e verticalização, conforme apontado por Abramo (2001). Os lançamentos realizados nesta área no período analisado ainda eram predominantemente incorporados por empresas familiares locais de pequeno e médio porte. Contudo, o que se pode aferir é que os empreendimentos mais representativos lançados na região (e no restante da cidade) em relação ao porte, foram produzidos por grandes incorporadoras que viriam a abrir seu capital na bolsa a partir de 2006, como a PDG - em parceria com a construtora local CHL - e a Rossi. 
Mapa 9. Lançamentos dos empreendimentos das empresas que abriram capital a partir de 2005 na cidade do Rio de Janeiro por porte (2000-2006)

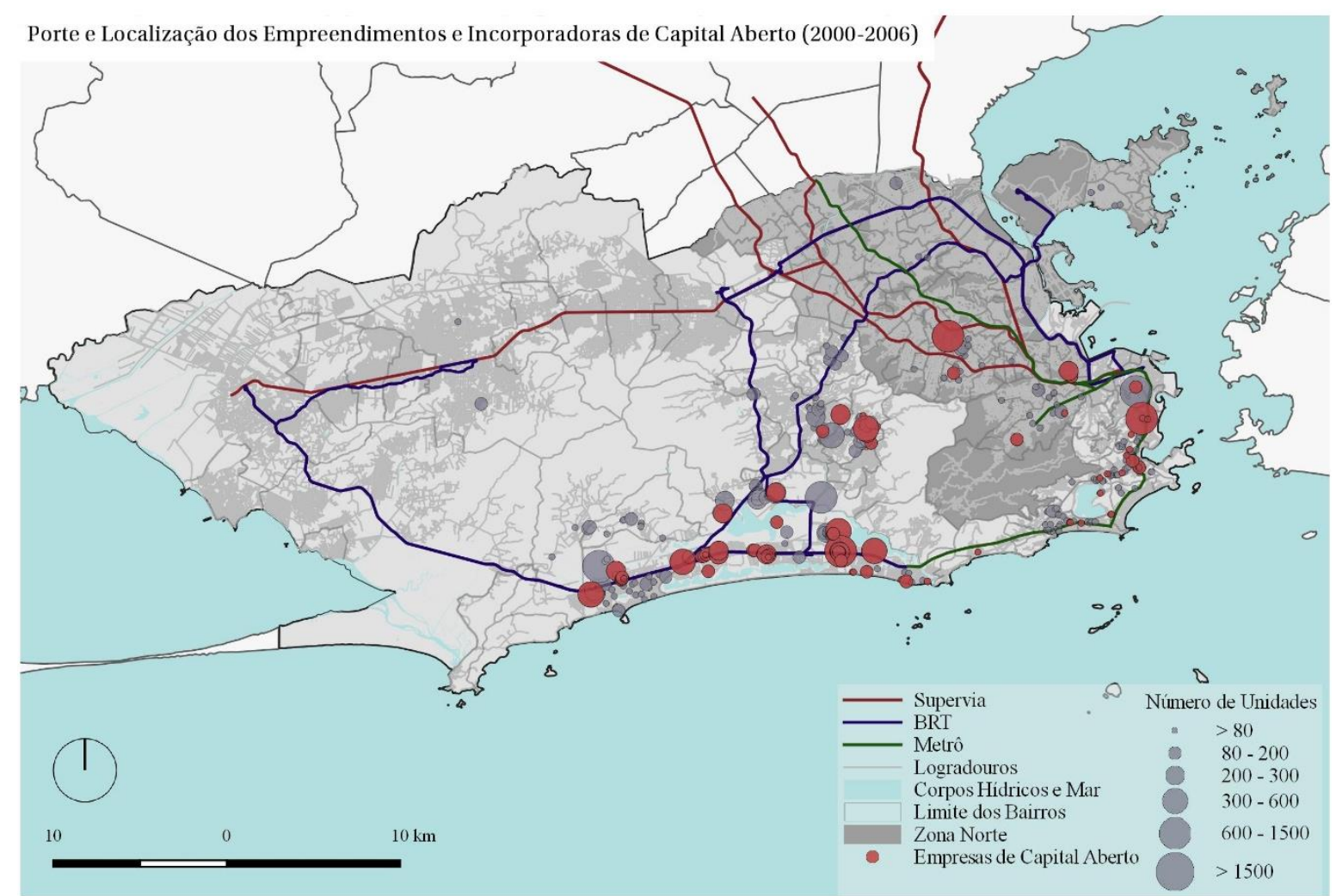

Fonte: elaboração do autor em parceria com Paula C. Moreira a partir de dados da Ademi

Em síntese, o que se pode notar a partir da observação do mapa anterior é ainda uma grande concentração de lançamentos imobiliários em áreas já consolidadas enquanto lócus de reprodução ampliada do capital pelo imobiliário na cidade, como a Barra da Tijuca e a Zona Sul. Esta última já de maneira menos intensa, como já comentado.

Não obstante, o que se nota a partir da abertura de capital das grandes incorporadoras nacionais é, além da produção intensiva de novos empreendimentos, uma expansão das fronteiras de acumulação que engendra uma dispersão concentrada no que diz respeito à geografia da cidade, para regiões até então preteridas por este mercado, configurando a partir disso o que conceitualmente convencionamos chamar de reestruturação imobiliária ${ }^{187}$. Essa dispersão concentrada se conforma, por um lado, pela inegável disseminação da formacondomínio para todo o território da cidade que, por sua vez, "dá força para que a indústria da construção imobiliária se consolide ainda como uma indústria de propriedade" ${ }^{188}$, como mostra o mapa 8, mas também pela concentração desses empreendimentos no entorno de

\footnotetext{
187 Tomando o já explicitado conceito de Pereira (2013, p. 100)

${ }^{188}$ RUFINO, 2017, p. 218
} 
determinadas centralidades ou infraestruturas, sobretudo as de mobilidade, reforçando-as enquanto condições gerais a partir da valorização e por elas sendo reforçadas como mecanismos de capitalização. Como sintetizado por Pereira (1984),

a renda imobiliária provém do caráter de monopólio de privatização do espaço que, pela necessidade de se pagar o acesso à localização, torna possível a formação de um preço de mercado imobiliário que sobe até os limites permitidos pelas condições de pagamento na disputa pela utilização do espaço (PEREIRA, 1984, p. 245 apud LENCIONI, S. 2015, p. 152)

É nessa lógica que as infraestruturas de mobilidade, somadas a outros elementos como o aumento dos índices de adensamento, instalação das UPPs e políticas de financiamento, passam a ter um papel fundamental na formulação do planejamento. A partir da conexão desses elementos é que se permitiu a produção de empreendimentos imobiliários impensáveis anteriormente. Nesse processo, são as grandes incorporadoras que mais se apropriam dessa possibilidade de capitalização, fazendo com que seus imóveis alcancem preços bastante descolados dos preços de produção. Sem ações como essas, seria impossível que essas empresas atingissem a expansão pressuposta em seus processos de abertura de capital.

Essa expansão pode ser confirmada concretamente através dos números de unidades lançadas na cidade entre 2007 e 2015. Embora a participação dos bairros que compõem a AP 4, sobretudo a Barra e Jacarepaguá (Freguesia, Pechincha, Taquara, etc.), ainda sejam extremamente relevantes para o setor, concentrando a maior parcela (46\%) dos empreendimentos lançados na cidade, o que se percebe é um considerável arrefecimento da importância dessa região em relação ao período anterior onde era soberana.

Já a AP 2 (Zona Sul e Grande Tijuca), embora tenha mais que dobrado, em números absolutos, a quantidade de unidades lançadas neste período em relação ao anterior, sua participação no total da cidade caiu de $15 \%$ para $6 \%$. O mesmo acontece com a AP 1 que aumentou substancialmente a quantidade de unidades lançadas (5,5 vezes), mas que se manteve nos mesmos $4 \%$ do período anterior. Contudo, o que chama atenção neste caso específico da AP 1 é a não realização do que se projetara para a área com a instituição da OUC Porto Maravilha ${ }^{189}$ e todo o sofisticado desenho financeiro para sua viabilidade. A

\footnotetext{
${ }^{189}$ Foge ao escopo desta dissertação aprofundar as minúcias da formulação da OUC Porto Maravilha, bem como as questões que levaram ao (in)sucesso da mesma e os conflitos gerados na disputa por este espaço entre capital e Estado de um lado e movimentos de luta por moradia do outro. Para maiores esclarecimentos acerca do tema, consultar os trabalhos de Cardoso (2013), Halfen (2014) e Werneck (2016).
} 
região portuária carioca foi eleita, no final da década passada, a "bola da vez" na expansão da fronteira imobiliária e turística da cidade com a reconversão do obsoleto uso portuário para dar lugar a luxuosos empreendimentos de usos corporativo e hoteleiro em sua predominância, ainda que também estivesse previsto a intensificação do uso residencial.

A AP 5, sem dúvidas, foi a área da cidade que mais se destacou nesse processo de expansão das fronteiras para o subúrbio do Rio de Janeiro. No período anterior, a participação da AP 5 era bastante residual, com apenas $1 \%$ das unidades lançadas, porém, entre 2007 e 2015 , esse percentual aumenta para $1 \frac{1}{4}$, ou seja, $25 \%$ de todas as unidades lançadas na cidade. Esse salto surpreendente é explicado, sobretudo, por conta da atuação do PMCMV na região onde, como já dito anteriormente, 55,5\% dos empreendimentos vinculados ao programa foram lançados, sobretudo os empreendimentos Faixa 1, que chamam atenção pelo gigantismo de seus portes. Esses números podem ser analisados a partir do gráfico seguinte.

Gráfico 11. Participação do número de unidades lançadas na cidade do Rio de Janeiro por Área de Planejamento entre 2007 e 2015

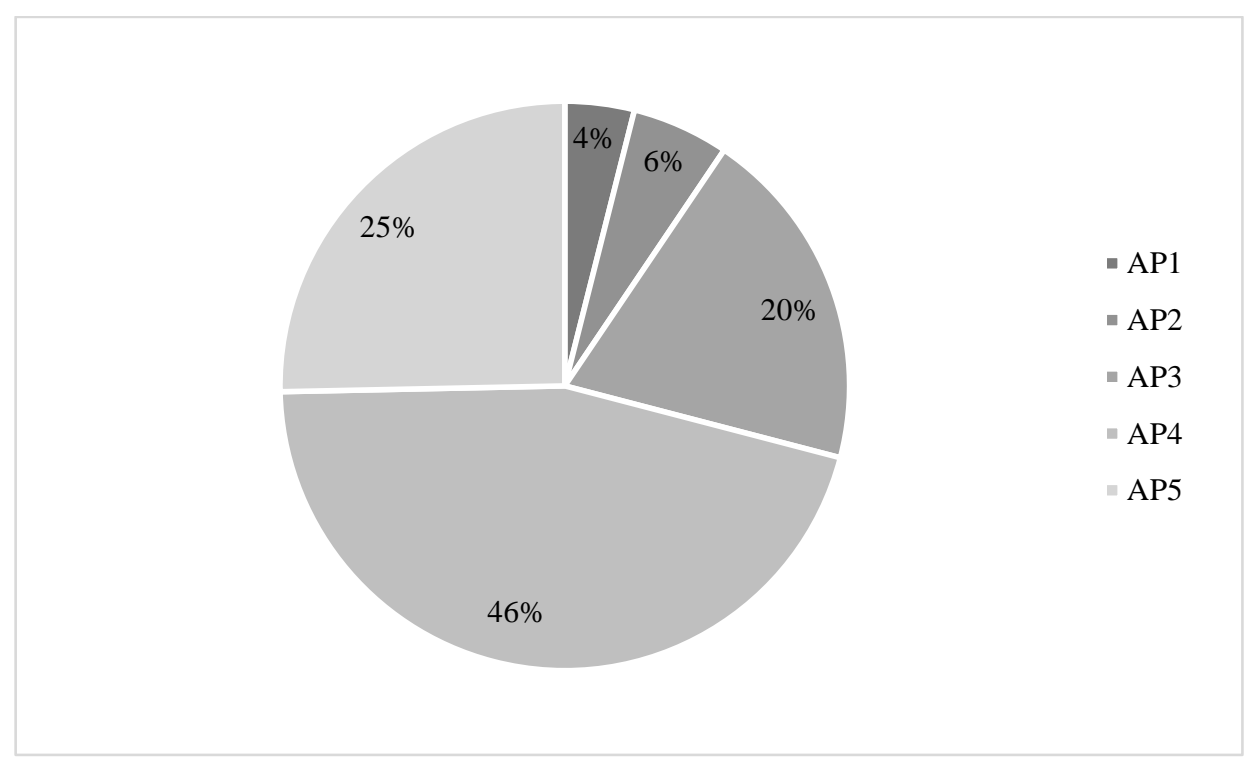

Fonte: elaboração própria com base em dados da Ademi

Embora não seja a área de planejamento que mais se destaca pelo volume de unidades lançadas no período entre 2007 e 2015 (20\% contra 7\% do período anterior), a AP 3 tem particularidades que fazem dela um objeto privilegiado para as discussões a que esta dissertação se propõe. Vale relembrar aqui que, a despeito da franca expansão da produção imobiliária observada na AP 3, as grandes intervenções públicas de infraestrutura, as UPPs e as legislações urbanísticas criadas foram fundamentais para transformar a região e fazer 
dela a área onde a variação do preço da terra foi mais aguda em comparação ao restante da cidade.

É indiscutível que a abertura de capital pelas grandes incorporadoras brasileiras teve um impacto decisivo na produção do espaço contemporânea das metrópoles brasileiras. No Rio de Janeiro, esses impactos se tornam bastante claros quando se observa a expansão imobiliária para a Zona Norte suburbana da cidade (AP 3). Conforme assinalado por Penha Filho e Mioto (2017), a inédita abertura de capital pelas empresas do setor imobiliário, modificou, logo de partida, a tradicional organização empresarial dessas empresas, predominantemente familiar, fazendo com que essas empresas "passassem a operar sob a lógica da valorização dos ativos no mercado financeiro, transformando significativamente suas operações"190.

A abertura de capital intensificou também um processo inerente ao próprio modo de produção capitalista e que, no setor da construção civil, tinha certa resistência a se concretizar devido suas características particulares, a saber, o processo de centralização do capital, conforme já descrito anteriormente à luz dos trabalhos de Aglietta (1986) e Lencioni (2017). O processo de concentração de capital que se estabeleceu a partir da abertura de capital, alterou o histórico padrão do setor de predominância de empresas pequenas e médias, conferindo a essas empresas de capital aberto um crescimento excepcional. Mas é a partir do processo de centralização do capital que se estabelece um cenário de aquisições e fusões de empresas menores, fazendo com um grupo restrito de empresas fosse responsável pela concentração de uma parcela extremamente relevante da produção imobiliária nessas grandes incorporadoras e, com isso, concentrando também boa parte da mais-valia global advindos de toda a produção. O gráfico a seguir sintetiza essa discussão com maior clareza, ao mostrar que apenas 11 incorporadoras, todas as de capital aberto que atuavam ou passaram a atuar na cidade do Rio de Janeiro, foram responsáveis por $44,5 \%$ de toda a produção de unidades habitacionais ${ }^{191}$ entre 2007 e 2015 e, se levarmos em consideração apenas as cinco primeiras deste ranking - Cyrela/Living, PDG, Gafisa/Tenda, Even e MRV - esse percentual é de $32,7 \%$ do total.

\footnotetext{
190 PENHA FILHO e MIOTO, 2017, p.03

${ }^{191}$ É necessário deixar registrado para que não fique a impressão de que apenas as empresas de capital aberto foram responsáveis pelo grande volume de produção na cidade que a Emccamp, construtora paulistana de capital fechado, foi responsável por 6,2\% de toda a produção no período analisado. Porém, a empresa atuou exclusivamente na construção de empreendimentos Faixa 1 do PMCMV, numa lógica particular de produção e distinta ao que vem sendo abordado aqui.
} 
Gráfico 12. Participação das incorporadoras de capital aberto no lançamento de novos empreendimentos imobiliários da cidade do Rio de Janeiro (2007-2015)

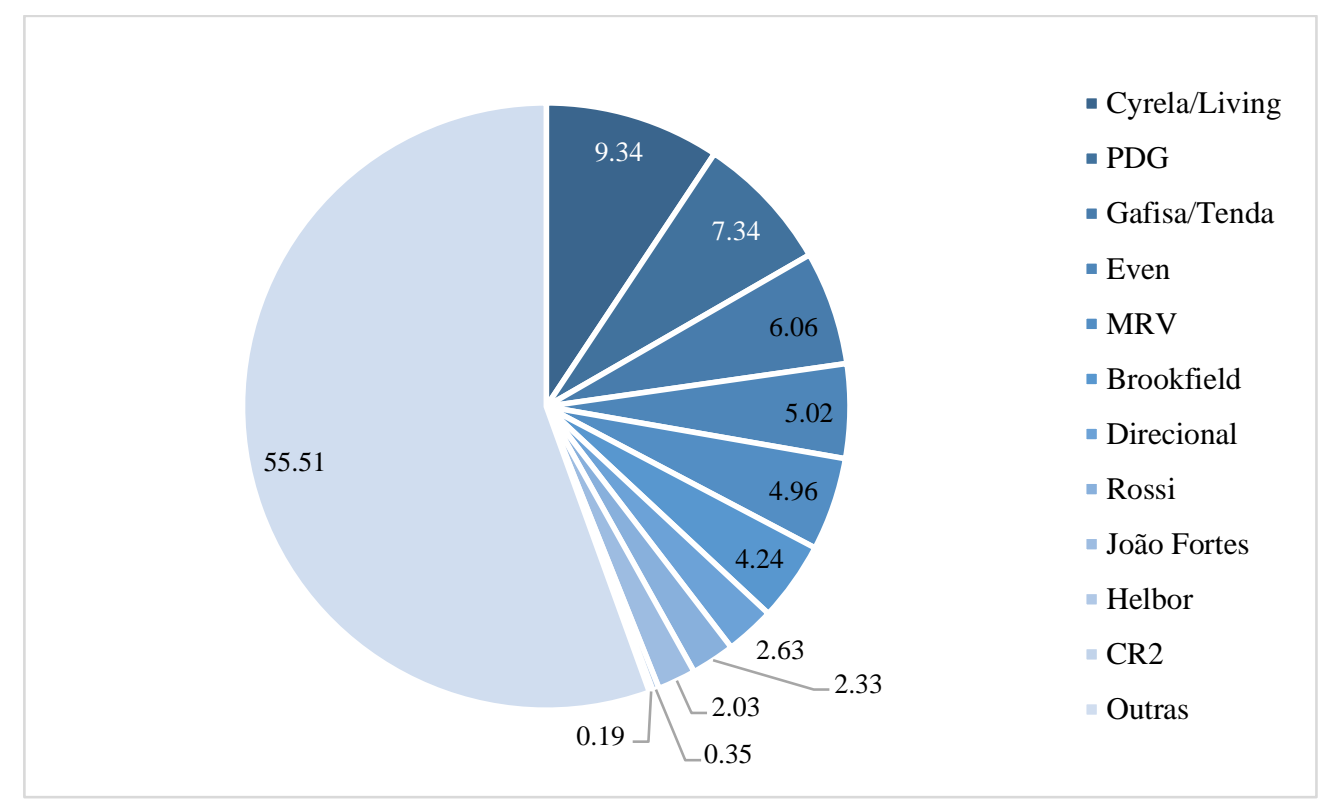

Fonte: elaboração própria com base em dados da Ademi

Quando se correlaciona os dois últimos gráficos expostos, observa-se que a produção dessas empresas de capital aberto altera o padrão de produção do espaço na atualidade, reforçando o processo de reestruturação imobiliária, cuja característica se dá "por uma maior intensidade na exploração de novas fronteiras imobiliárias, extrapolando uma histórica tendência de concentração nos territórios mais valorizados, e pela grande escala dos empreendimentos"192. Assim, Rufino (2017) aponta que

\begin{abstract}
a forte centralização de capital no setor, apoiada na ampliação das condições de consumo via crédito, irá viabilizar por meio de diferentes estratégias "espaciais" o crescimento contínuo imposto pelo capital financeiro. Tal movimento apropria-se e impõe mudanças do/no território da metrópole ao explorar novas fronteiras imobiliárias e intensificar a construção, ampliando a dimensão dos empreendimentos. Pela visível ampliação da escala dos empreendimentos, esse movimento de centralização do capital dá força também à articulação entre infraestruturas e imóveis - entendida como importante estratégia de valorização e capitalização (RUFINO, 2017, p. 232)
\end{abstract}

O mapa seguinte sinaliza essa forte expansão da fronteira de acumulação, transformando essa área em lócus privilegiado de reprodução do capital pelo imobiliário, ou seja, a partir da valorização e da capitalização.

${ }^{192}$ RUFINO, 2017, p. 232 
Mapa 10. Lançamentos dos empreendimentos das empresas de capital aberto na cidade do Rio de Janeiro por porte (2007-2015)

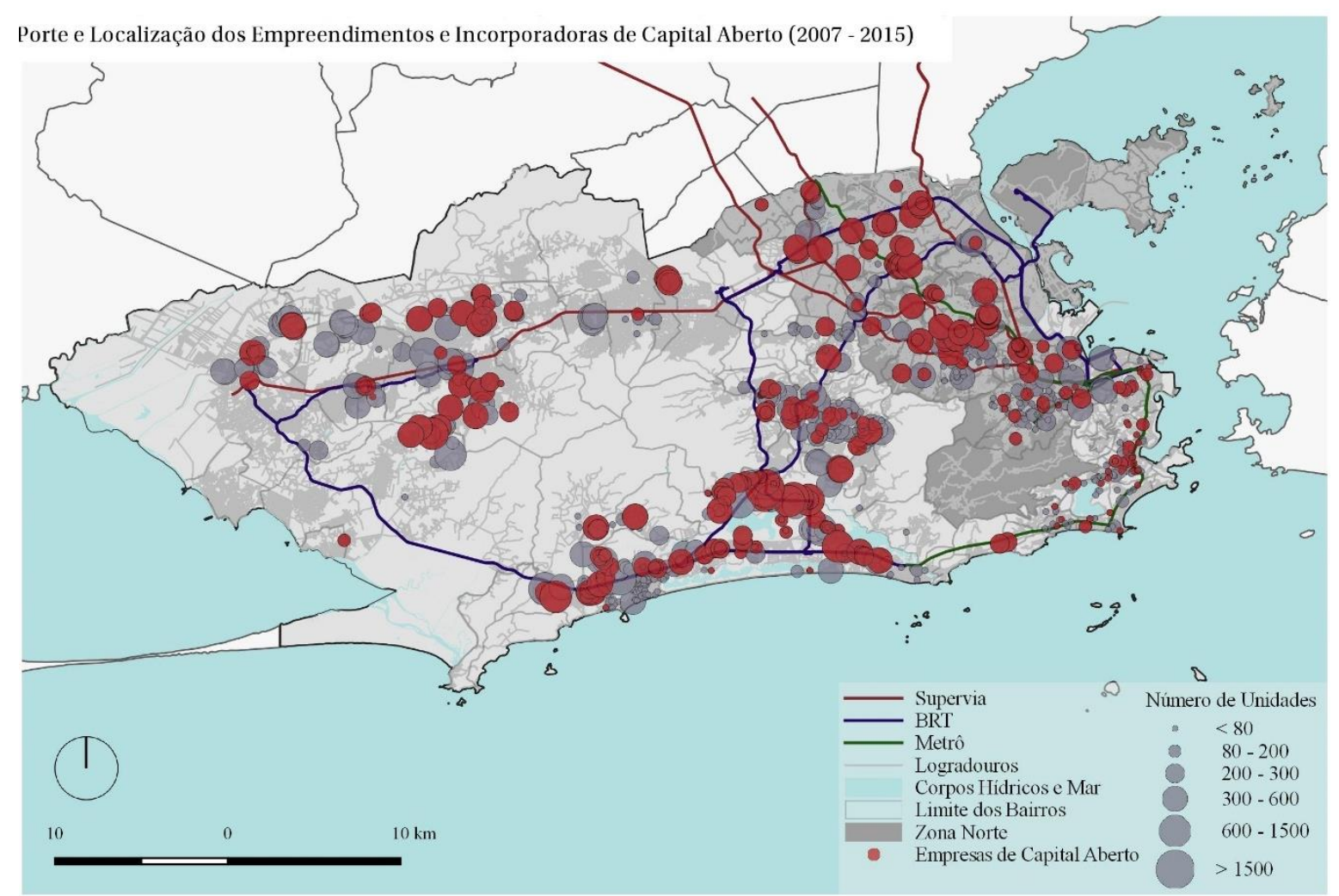

Fonte: elaboração do autor em parceria com Paula C. Moreira a partir de dados da Ademi

No interior dessa reestruturação, os terrenos que abrigavam antigas indústrias desativadas em função da reestruturação produtiva na Zona Norte e os espaços precários do ponto de vista da infraestrutura na Zona Oeste (conforme exposto no item sobre o impacto do PMCMV na AP 5) tornam-se centrais para a expansão da fronteira imobiliária na cidade. No caso da Zona Norte, esses terrenos já eram razoavelmente assistidos do ponto de vista da infraestrutura, oriundos do período de concentração industrial na região, onde o escoamento da produção fabril e a mobilidade dos trabalhadores entre suas casas e seus postos de trabalho eram imperativos no ordenamento territorial e na implantação das mesmas. O que se verifica na contemporaneidade é a disputa pela captura dos espaços servidos por essas infraestruturas, com o objetivo impulsionar os processos de valorização-capitalização imobiliária.

No caso do Rio, a provisão de uma nova camada de infraestruturas, engendradas por e nessa lógica, vem para intensificar ainda mais esses processos. As imagens a seguir revelam com nitidez esse processo: em questão, antigas áreas industriais nos bairros Vila da Penha (superior) e Del Castilho (inferior), ambas na Zona Norte carioca (AP 3), que deu lugar, após 
longo período de ociosidade, a empreendimentos de grande porte produzidos por um grupo de incorporadoras de capital aberto (Brookfield e Rossi no primeiro caso e PDG e Cyrela/Living no segundo). É explícita a relação dos empreendimentos com a Linha 2 do Metrô e com o corredor BRT TransCarioca, no caso da Vila da Penha e com a Linha Amarela, no caso de Del Castilho, infraestruturas de mobilidade de épocas distintas, mas que são capturadas com a mesma finalidade neste atual contexto de reestruturação imobiliária. Outra questão que ganha relevo é o da sobreposição temporal das camadas de urbanização e metropolização: o impacto desses empreendimentos no território intensifica os processos de homogeneização, fragmentação e hierarquização do espaço, indicando uma apropriação seletiva do espaço "onde a intensificação e qualificação das infraestruturas tendem a ser projetadas em função da obtenção de ganhos futuros a partir dos empreendimentos imobiliários, potencializando rendas imobiliárias e financeiras"193.

Figura 6. Implantação de novos empreendimentos de grande porte na Zona Norte
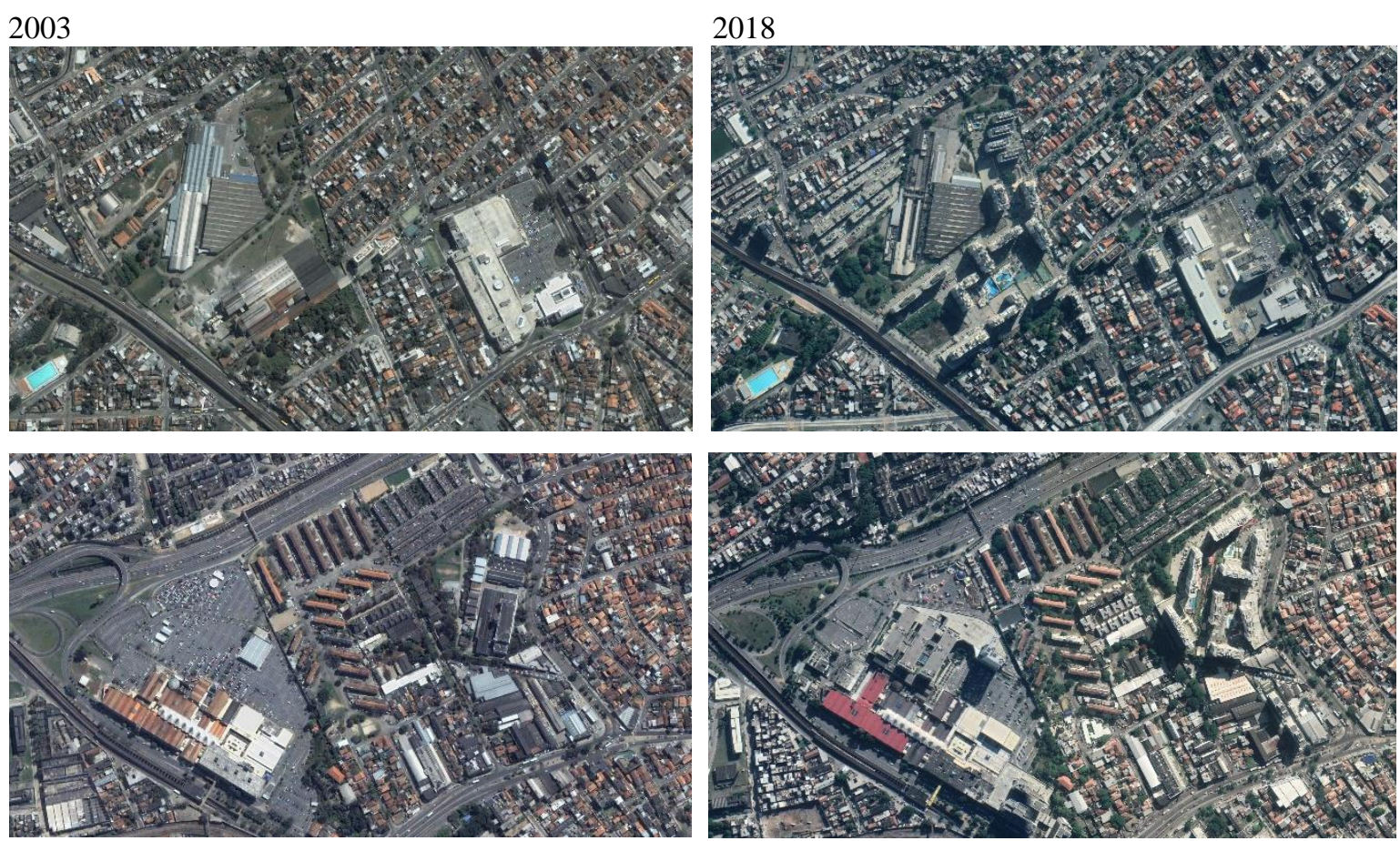

Fonte: Google Earth

Conforme já assinalado, é evidente na AP 3 uma forte hierarquização dos condomínios nesse processo de reestruturação imobiliária frente a outros espaços da cidade. Portanto, seguindo a mesma lógica dos casos anteriores, mas com algumas particularidades, ainda há os empreendimentos de incorporadoras de capital aberto, como a MRV, que se localizam em

193 Ibid., p. 233 
bairros menos valorizados da Zona Norte, como Colégio (superior) e Guadalupe (inferior), ilustrados nas imagens a seguir. Na maioria dos casos, esses empreendimentos estão vinculados ao PMCMV (faixa 3) e, pelo opulento porte, ocupam também antigas áreas industriais. Essas incorporadoras passam a ter uma atuação privilegiada nesse território e, de certa forma, esses empreendimentos também se apropriam da infraestrutura já existente embora mais precária que da área anterior - como estratégia de aumentar seus ganhos e como forma de se conectar a outros espaços da metrópole. Contudo, o que ganha destaque nesses casos é a intensificação da segregação socioespacial a partir da fragmentação do território. Como se pode observar nas ilustrações, as diversas camadas temporais são bastante evidentes, como a do condomínio, da favela (Para Pedro, no caso de Colégio), das casas operárias (no caso de Guadalupe) e dos resquícios do período industrial.

Figura 7. Implantação de novos empreendimentos de grande porte na Zona Norte

2003
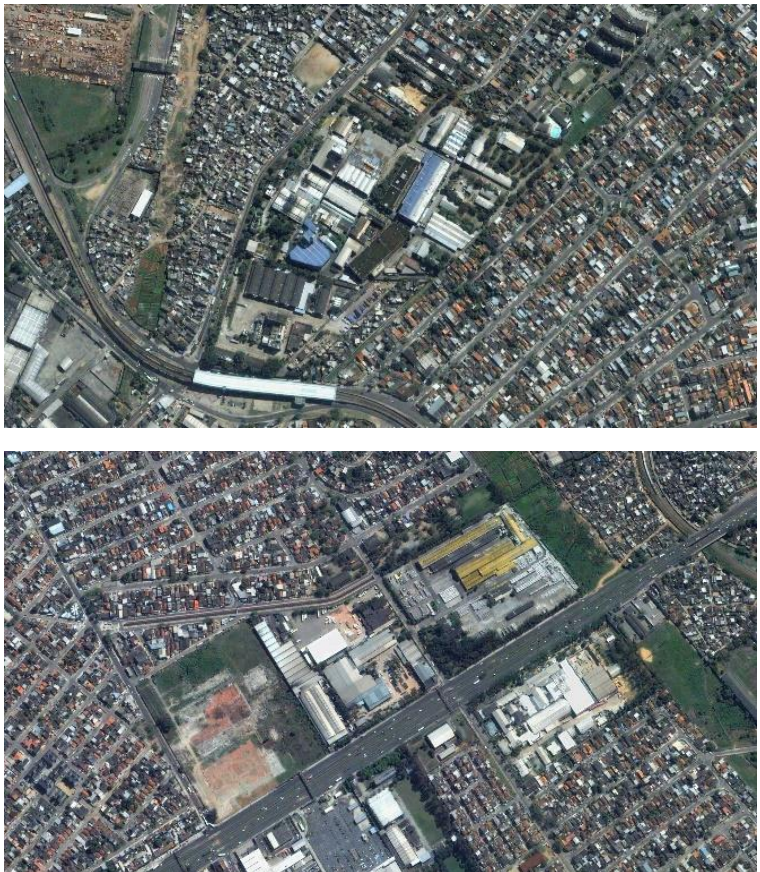

2018
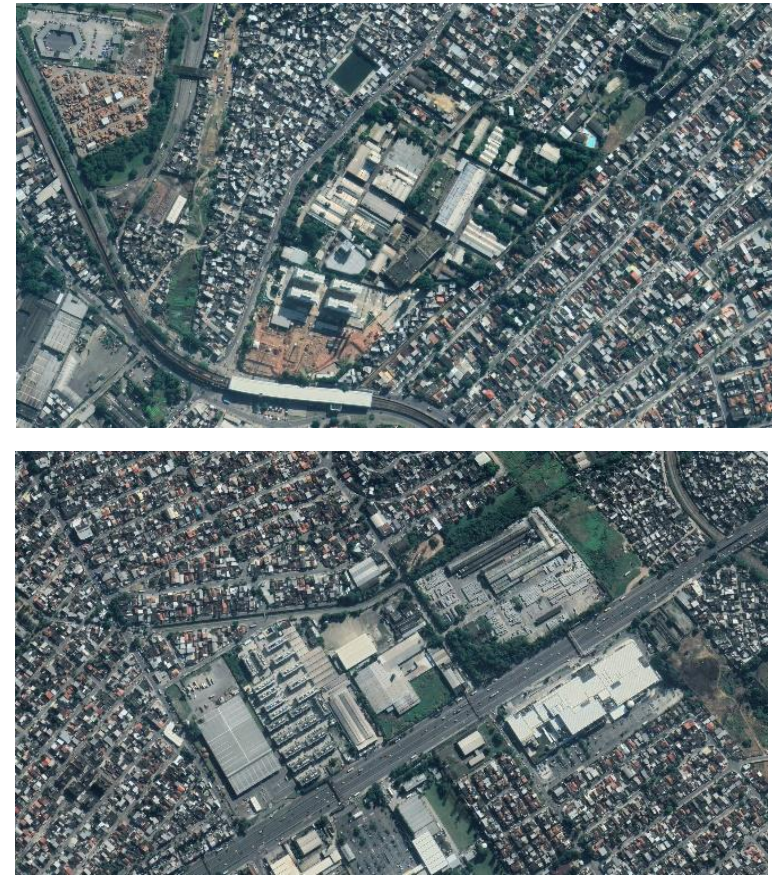

Fonte: Google Earth

Embora esse atual processo de reestruturação imobiliária com características tipicamente financeiras tenda a se generalizar e impactar todo o território da metrópole carioca, é no subúrbio da Zona Norte onde a manifestação desse processo é mais concreta. Nas outras áreas, embora a participação dessas empresas tenha relevância, não se vê o mesmo protagonismo do grupamento de empresas de capital fechado. A tabela seguinte revela a parcela ocupada pelas empresas de capital aberto na produção total de cada Área de 
Planejamento do município do Rio de Janeiro. A AP 3 foi a única região da cidade onde a produção imobiliária das empresas de capital aberto foi superior ao das outras empresas.

Tabela 7. Participação das incorporadoras de capital aberto no lançamento de novos empreendimentos imobiliários na cidade do Rio de Janeiro por AP (2007-2015)

\begin{tabular}{cc}
\hline \multicolumn{2}{c}{$\begin{array}{c}\text { Participação das empresas } \\
\text { de Capital Aberto por } \\
\text { Área de Planejamento (AP) }\end{array}$} \\
\hline AP1 & $27,70 \%$ \\
AP2 & $36,23 \%$ \\
AP3 & $61,37 \%$ \\
AP4 & $44,51 \%$ \\
AP5 & $34,39 \%$ \\
\hline
\end{tabular}

Fonte: elaboração própria com base em dados da Ademi

Gráfico 13. Participação das incorporadoras de capital aberto no lançamento de novos empreendimentos imobiliários na AP 3: Rio de Janeiro (2007-2015)

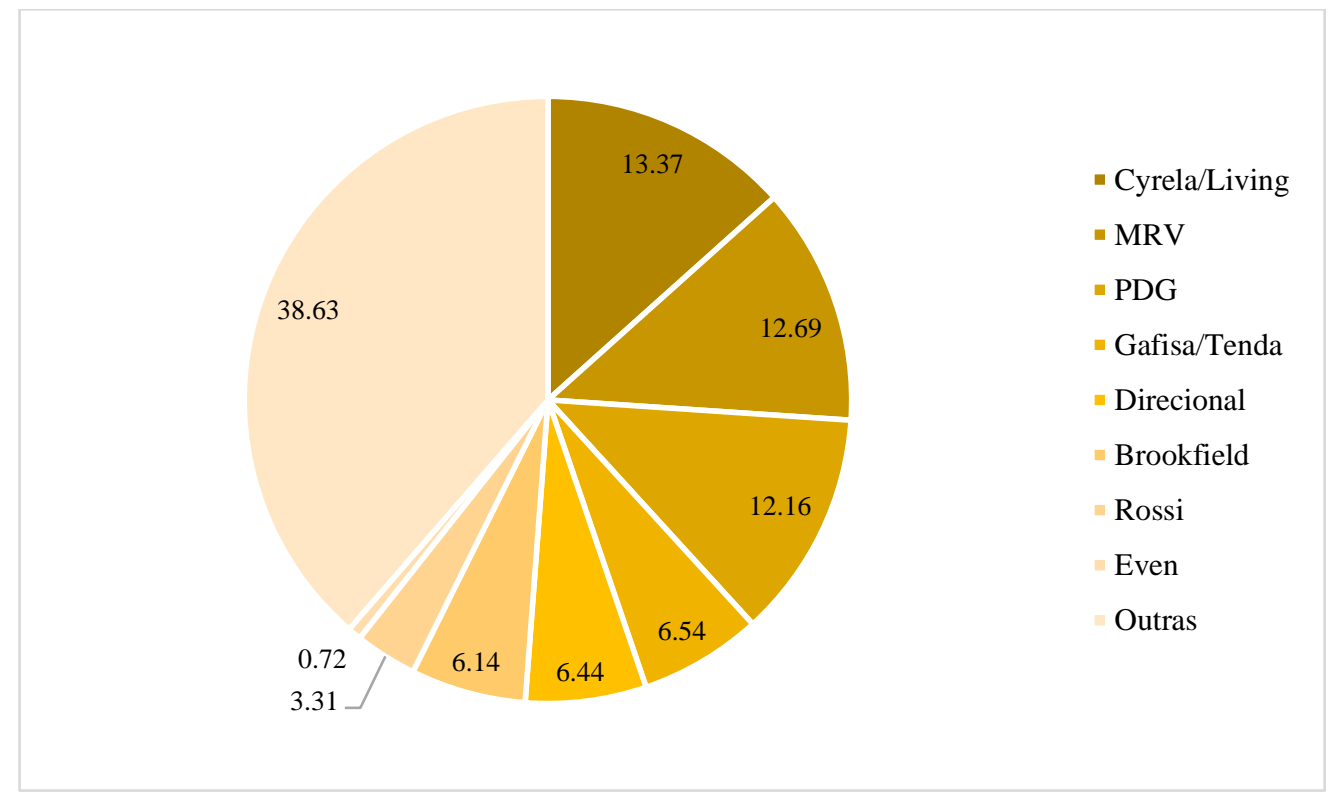

Fonte: elaboração própria com base em dados da Ademi

O gráfico anterior revela com mais clareza a concentração dos investimentos das incorporadoras de capital aberto, onde oito empresas concentram mais de $60 \%$ de toda a produção imobiliária da AP 3. Se ainda levarmos em consideração a produção das três primeiras incorporadoras nesse arranjo - Cyrela/Living, MRV e PDG -, o processo de concentração se mostra ainda mais evidente, pois somente elas detém mais da metade da 
produção das incorporadoras de capital aberto, demonstrando a força que essas empresas tem no âmbito nacional e que se reforça mais concretamente no contexto local.

Nesse sentido, a AP 3 (ou Zona Norte suburbana) que no período urbano-industrial ao longo do século XX era um espaço caracterizado como lócus privilegiado de rebaixamento da força de trabalho, torna-se, na atualidade, estratégico como frente de expansão da reprodução do capital através da produção do seu espaço e a manifestação mais acabada nesse processo de reestruturação empreendida a partir do boom imobiliário iniciado em 2007 na cidade do Rio de Janeiro e que se caracteriza fundamentalmente pelo entrelaçamento da esfera financeira com o imobiliário. Esses processos podem ser compreendidos com maior facilidade a partir da análise crítica das três incorporadoras de capital aberto mais representativas na área estudada, bem como de sua produção e o impacto que seus empreendimentos geraram no território.

\section{Cyrela: trajetória e estratégia de atuação no Rio de Janeiro}

$\mathrm{O}$ ano de fundação da Cyrela enquanto incorporadora e construtora não é preciso, mas, segundo informações em seu site, a empresa foi criada em 1962 por Elie Horn, um sírio radicado no Brasil, que comandou a empresa até 2014 quando passou a presidência para seus dois filhos. Assim como a maioria das construtoras brasileiras, a Cyrela tem uma tradição familiar de gestão de negócios. No início, a Cyrela se limitava às atividades de incorporações de edifícios residenciais e comerciais, terceirizando todo o processo de construção e venda. Em 1981, o grupo cria a Cyrela Construtora e a Seller Consultoria Imobiliária, centralizando todas as etapas - da incorporação à comercialização.

Em 1994, constitui-se a Brazil Realty numa joint venture com a empresa argentina Irsa (Inversiones e Representaciones S.A.) para construção e locação de lajes corporativas de alto padrão e, em 1996, fazem a primeira oferta pública de ações na bolsa de valores captando cerca de US\$80,5 milhões e se consolidando como empresa pioneira no desenvolvimento do FII no mercado imobiliário brasileiro.

No ano 2000, firma uma parceria joint venture com a carioca RJZ Engenharia para expandir sua atuação para o Rio de Janeiro. 
Em 2005, após uma grande reestruturação, passa a se chamar Cyrela Brazil Realty S.A. Empreendimentos e Participações. No mesmo ano, ingressa no Novo Mercado da Bovespa fazendo seu I.P.O. A partir de 2006, importantes fundos de investimento internacionais passam a compor o quadro acionário da Cyrela. No mesmo ano, tendo como estratégia a expansão geográfica e a diversificação de segmentos, passa a fazer joint ventures com algumas construtoras menores de outros mercados Brasil afora, como a Agra, a Mac, Plano \& Plano e a Goldsztein, além de fazer a aquisição completa da RJZ. Ainda em 2006, cria a marca Living para atuar no segmento "econômico".

Em 2007 firma uma joint venture com a Cury, construtora com vasto know how na atuação para o segmento "econômico", passando a controlar 50\% do capital da empresa. Esse seria o caminho para ingressar no Programa Minha Casa Minha Vida que viria acontecer pouco tempo depois. Em 2009 faz a aquisição total da Goldsztein e a Living torna-se uma empresa com estrutura independente e, além da atuação no segmento "econômico", passa a atuar para padrões "médios" fora do PMCMV.

Em 2016, a Cyrela passa a ser proprietária de 13,62\% da gigante do setor Tecnisa. E, em 2018, cria a subsidiária Vivaz para atuar exclusivamente no Programa Minha Casa Minha Vida.

Gráfico 14. Trajetória da Cyrela na Bovespa (2005-2016)

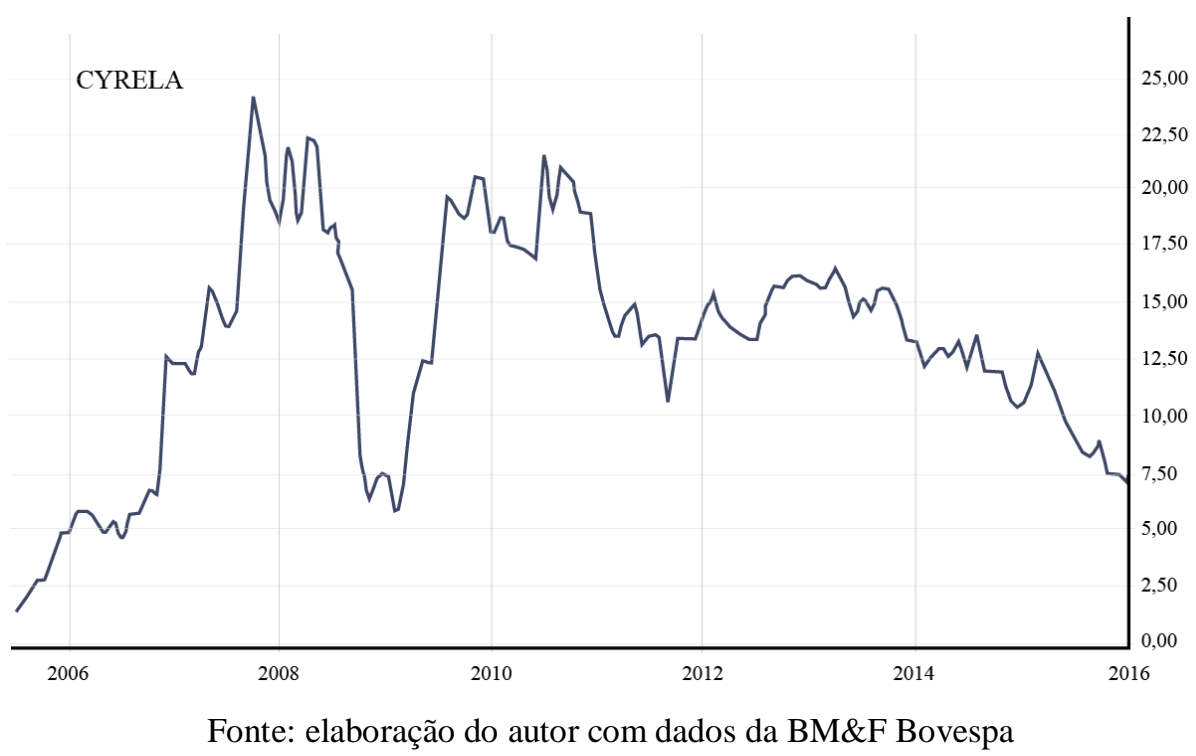

Como dito anteriormente, a estrutura acionária da Cyrela mostra um padrão onde, apesar do capital aberto e da necessidade em corresponder os anseios de seus acionistas, ela ainda possui um forte controle familiar. Esse padrão de empresa enxerga na abertura de capital 
uma forma de expandir sua atuação sem, no entanto, "perder a mão" dos caminhos da companhia. Nesse sentido, mais de $30 \%$ das ações da Cyrela estão concentradas na mão de seu fundador e também controlador. Junto a ele na controladoria, estão os antigos donos de empresas que foram incorporadas pela Cyrela. Os fundos internacionais de investimentos Dynamo e Orbis também compõem o quadro acionário com cerca de $20 \%$ das ações totais.

Tabela 8. Posição acionária da Cyrela (2017)

\begin{tabular}{lcr}
\hline \multicolumn{3}{c}{ Posição Acionária - Cyrela } \\
\hline Acionista & Nacionalidade & Ações Ordinárias (\%) \\
\hline Elie Horn* & Brasil & 24,55 \\
Dynamo & Inglaterra & 10,13 \\
Orbis Investment & Bermuda & 9,88 \\
Management & Brasil & 5,48 \\
Eirenor S.A.* & EUA & 4,68 \\
Capital Research Global & & \\
Investors & Brasil & 1,88 \\
EH Capital & Brasil & 1,58 \\
Management* & Brasil & 0,46 \\
Rogerio J. Zylbers ztajn* & - & 41,36 \\
Fernando Goldztein* & & \\
Outros & &
\end{tabular}

* Controladores

Fonte: Econoinfo

A Cyrela passa a atuar no Rio de Janeiro no início da década de 2000 a partir de uma joint venture com a incorporadora local RJZ, focada em empreendimentos de alto padrão em bairros da Zona Sul e Barra da Tijuca. Com o passar do tempo, a Cyrela vai aumentando sua participação dentro da empresa até integralizar sua compra em 2006. Entre 2000 e 2006, a produção da Cyrela na cidade do Rio de Janeiro concentrou-se na Barra da Tijuca, especialmente no entorno da Avenida das Américas, com o complexo de condomínios residenciais Le Parc, com 770 unidades e o complexo corporativo Le Monde com 1021 unidades, ambos no mesmo endereço, com unidades de $30 \mathrm{~m}^{2}$ custando em torno de $\mathrm{R} \$ 400$ mil. A Península da Barra, um loteamento de condomínios de alto padrão, também foi um local onde a Cyrela concentrou seus empreendimentos. Ali, lançou cinco empreendimentos com média de 200 unidades cada de alto padrão em parceria com a incorporadora do "dono da Barra" ${ }^{194}$ Carvalho Hosken, proprietária do loteamento. Neste ponto, o preço dos imóveis custava, em média, à época do lançamento, cerca de R \$ 650 mil.

\footnotetext{
194 Conforme matéria "Carlos Carvalho, o dono da Barra da Tijuca", veiculada na Exame em 15/06/2012: https://exame.abril.com.br/revista-exame/carlos-carvalho-o-dono-da-barra-da-tijuca/
} 
Os outros empreendimentos lançados pela incorporadora no período localizam-se, quase todos, na Zona Sul. São empreendimentos de pequeno porte, com uma média de 48 unidades por edificação, custando em média cerca de R 740 mil.

O único empreendimento fora desse tradicional circuito de incorporação imobiliária carioca é o condomínio Paço Real no bairro de São Cristóvão no ano de 2006, um ano após a abertura de capital na bolsa, o que já seria um prenúncio da característica expansão geográfica adotada pelo setor após a oferta de ações.

Mapa 11. Lançamentos da Cyrela na cidade do Rio de Janeiro por porte (2000-2006)

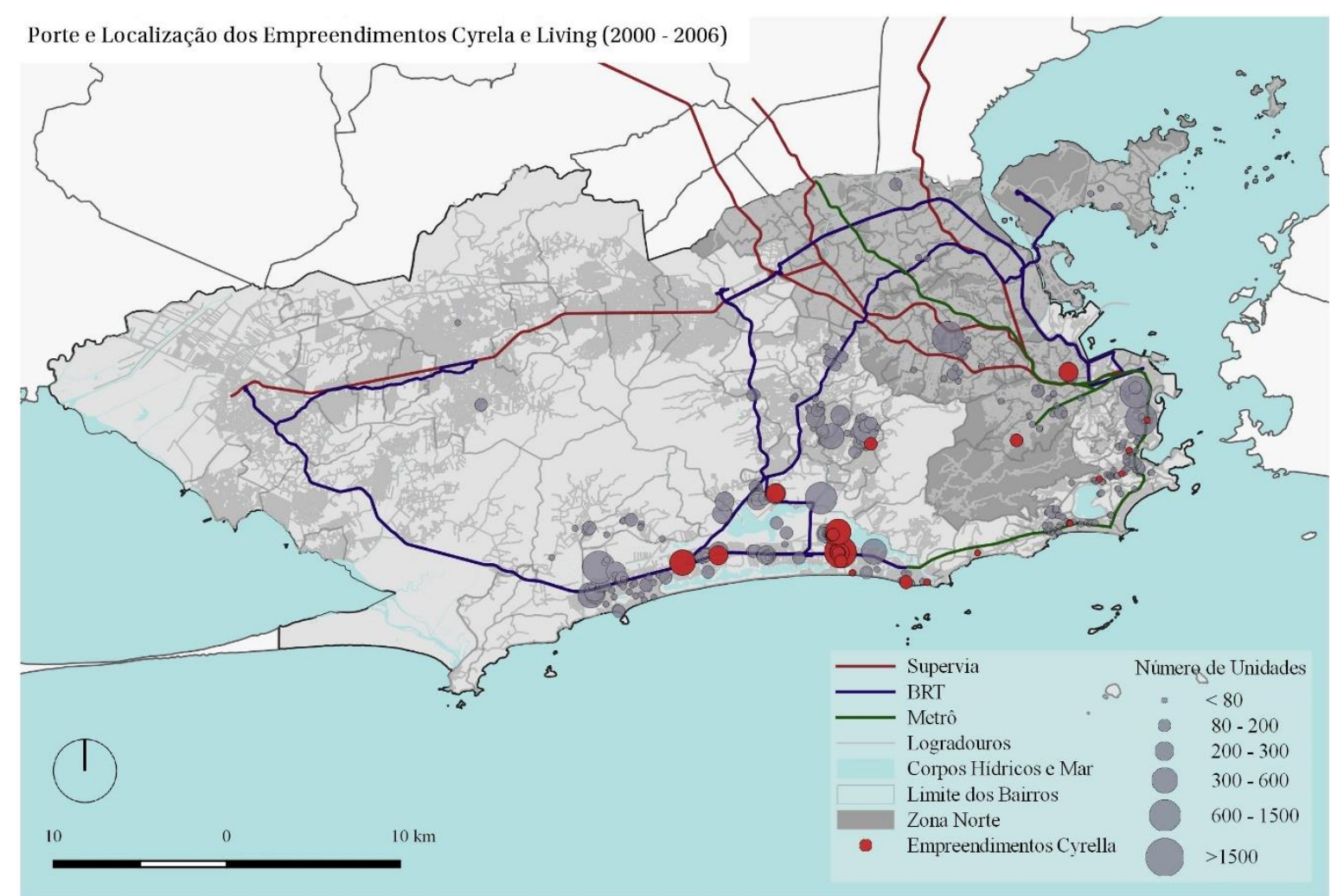

Fonte: elaboração do autor em parceria com Paula C. Moreira a partir de dados da Ademi

Conforme já aludido na trajetória da empresa, a Cyrela optou enquanto estratégia de atuação por fazer parcerias e até mesmo criar subsidiárias com estrutura independente para expandir sua atuação em outros segmentos de faixa de renda, preservando a marca principal, que se reservou a continuar lançando empreendimentos de alto padrão na cidade em territórios onde já estava estabelecida, como a Barra da Tijuca. Embora a maioria dos empreendimentos lançados pela marca Cyrela na Barra tenha sido através de incorporação própria, em alguns casos a empresa deu continuidade a joint ventures com a Carvalho Hosken e com a Brookfield, incorporadoras de grande porte, mas também com construtoras locais como a JC 
Gontijo Engenharia e a Rubem Vasconcelos. Neste último caso, a parceria envolvia a cessão dos terrenos por parte das construtoras, cabendo à Cyrela todo o restante da atividade de incorporação. Neste cenário de expansão, a Zona Sul perdeu destaque e teve tímidos quatro empreendimentos lançados pela incorporadora.

No subúrbio da cidade, a Cyrela estampou sua marca quase que exclusivamente na incorporação de grandes edifícios corporativos, como a Torre Norte Shopping no Cachambi com 360 unidades, o Nova América Offices em Del Castilho com 914 unidades, o Carioca Offices em Vicente de Carvalho com 360 unidades - todos anexos a shoppings homônimos - e o DHC Offices no bairro de Pilares com 442 unidades. Os únicos edifícios residenciais incorporados pela Cyrela nessa região foram o Norte Village Residencial com 533 unidades e o Norte Nobre com 166 unidade, ambos fortemente vinculados ao Norte Shopping e ao Power Center Linha Amarela - um complexo de hiperlojas de inspiração estadunidense, que abriga gigantes como a Leroy Merlin, o Walmart e o Sam's Club.

Contudo, foi através da subsidiária Living que a produção da Cyrela expandiu consideravelmente para a Zona Norte, Zona Oeste e baixada de Jacarepaguá visando atender os segmentos "econômico" e "médio". Para atuar no segmento "econômico" e nas faixas 2 e 3 do PMCMV, a Living se aliou à expertise da Cury neste mercado através de uma joint venture. O exemplo que chama mais atenção pelo porte, é o empreendimento Estação Zona Norte no bairro da Pavuna com 980 unidades. Outros exemplos importantes de serem ressaltados como fruto dessa parceria são os empreendimentos Completo Zona Norte em Tomás Coelho com 440 unidades e o Dez Rocha Miranda em Rocha Miranda com 444 unidades. Apesar de os três empreendimentos citados possuírem uma relação bem estreita com as infraestruturas de mobilidade da cidade, se encontram em regiões bastante precárias. 
Figura 8. Empreendimento Estação Zona Norte, no bairro da Pavuna: joint venture entre a Living e a Cury

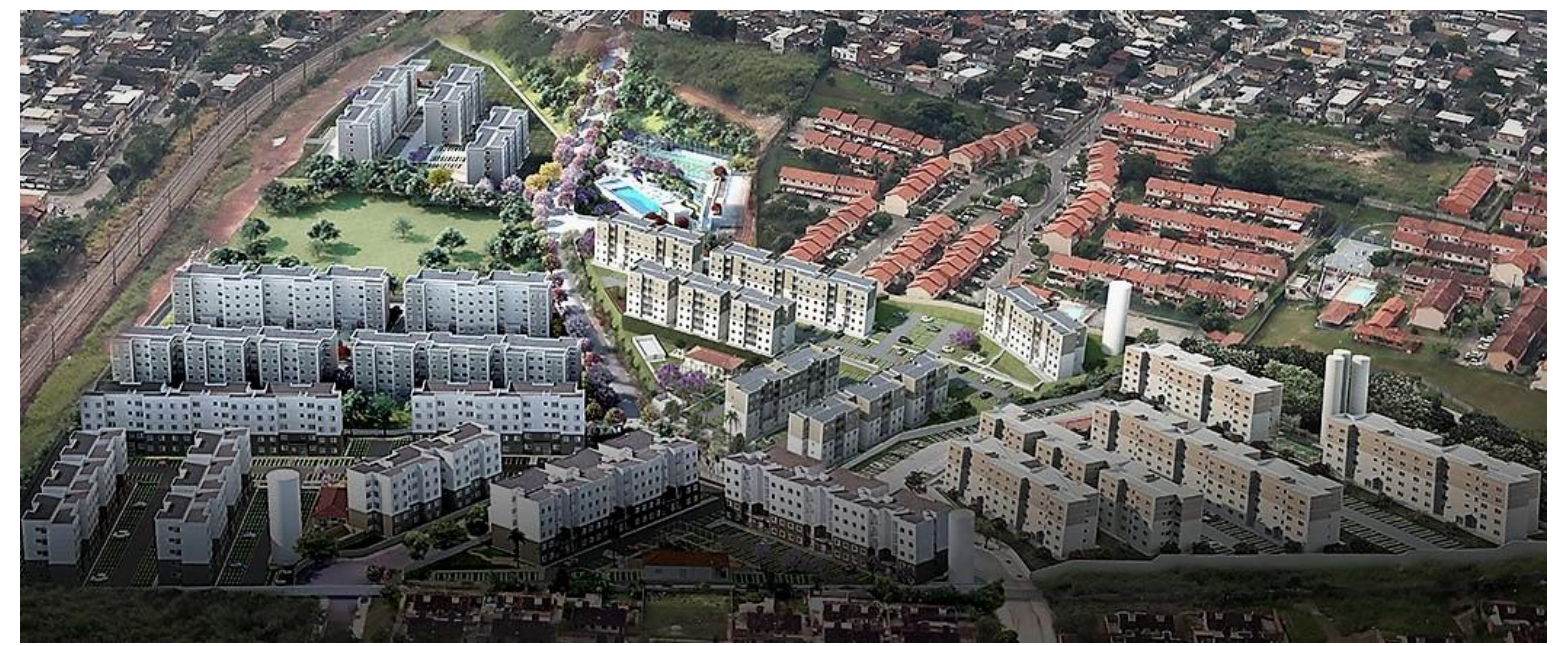

Fonte: www.cury.net/imovel/estacao-zona-norte-berlim

Outra joint venture importante feita pela Living foi com a PDG para construção de um grande complexo com dois empreendimentos residenciais e um conjunto de lojas voltado para o segmento "médio" no bairro de Del Castilho. Trata-se dos condomínios Rio Parque e Carioca Residencial, com 815 e 732 unidades, respectivamente. Ainda no segmento "médio", a Living lançou sozinha outros empreendimentos na Zona Norte como o Vidamérica Clube em Del Castilho com 356 unidades, dentre outros. O gráfico abaixo mostra os lançamentos da Cyrela/Living entre 2005 e 2015, onde se nota a evolução crescente do segmento "médio" e das Faixas 2 e 3 do PMCMV sem, no entanto, deixar de lançar empreendimentos voltados para o "alto" padrão. Além disso, o que se percebe é que esses empreendimentos para o segmento "médio" estão concentrados em alguns bairros adjacentes, com relação bem forte com a Linha 2 do metrô, o ramal Deodoro da Supervia e com a Linha Amarela, no que diz respeito à infraestrutura de mobilidade, mas também a grandes complexos de comércio e serviço, como pode-se ver no mapa após o gráfico. 
Gráfico 15. Série histórica de lançamentos da Cyrela por segmento de mercado na RMRJ

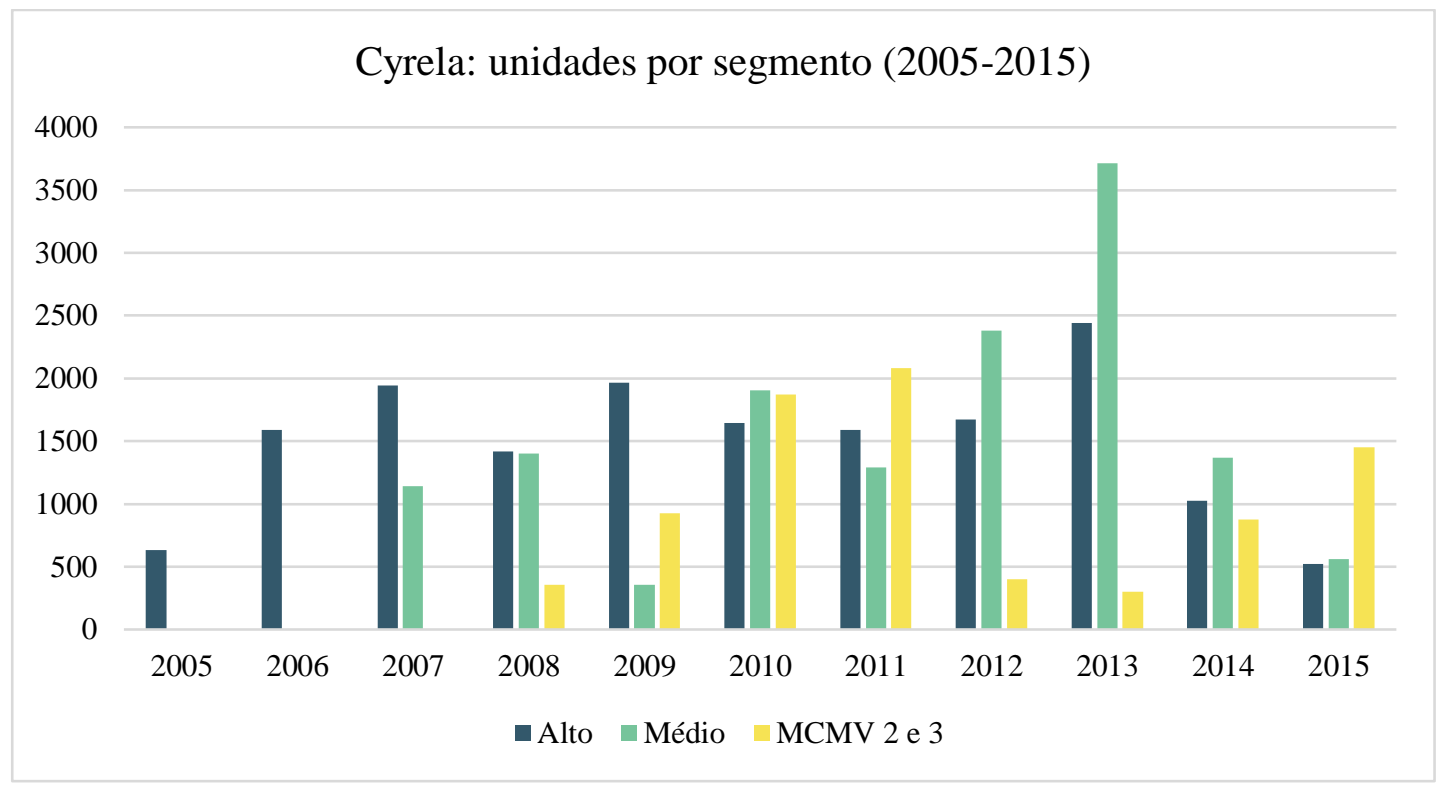

Fonte: elaboração do autor a partir de dados dos relatórios de resultados anuais da Cyrela

Mapa 12. Lançamentos da Cyrela na cidade do Rio de Janeiro por porte (2007-2015)

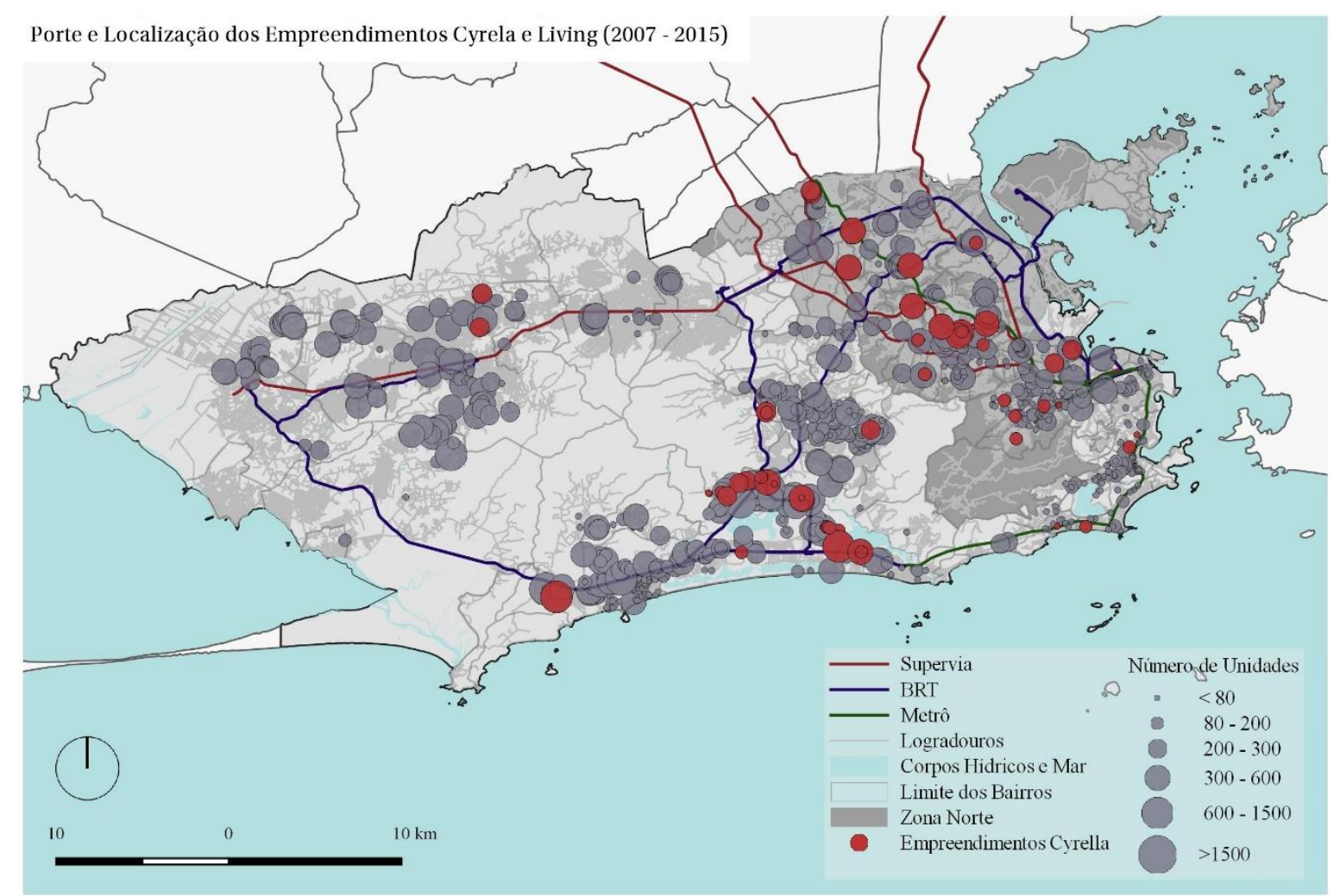

Fonte: elaboração do autor em parceria com Paula C. Moreira a partir de dados da Ademi 


\section{MRV: trajetória e estratégia de atuação no Rio de Janeiro}

A MRV tem como característica particular a sua tradição em empreendimentos populares. A construtora mineira foi fundada na cidade de Belo Horizonte no ano de 1979 pelos irmãos Márcio e Rubens Menin em sociedade com a Vega Engenharia, daí o nome MRV, tendo como foco principal a construção e incorporação de empreendimentos para este segmento de renda. Toda essa expertise adquirida pelas décadas de atuação para segmentos mais populares é um dos motivos pela qual a MRV é a mais relevante incorporadora atuando no PMCMV, programa este na qual a incorporadora atuou decisivamente no desenho institucional.

Cerca de 10 anos antes de abrir capital na bolsa, no ano de 1996, a MRV expandiu sua atuação para São Paulo e Região Sul do país. Em 2004, expandem ainda mais para todo Centro-Oeste, Sudeste, Bahia e Ceará.

Como apontado por Fix (2011), a MRV se aproxima do mercado financeiro em 2006 a partir de um movimento próprio de private equity, quando vende $16,7 \%$ do seu capital para o fundo de investimento estrangeiro Autonomy Capital Research. Poucos meses depois, já em 2007, faz seu I.P.O. na Bovespa, arrecadando cerca de R 1,071 bilhões derivados desta oferta primária. Recursos estes destinados à aquisição de novos terrenos e construção de novos empreendimentos. Ainda em 2007 torna-se a primeira empresa do setor imobiliário a ser correspondente da CEF. Essa parceria com o banco estatal permitiu que a própria MRV fizesse as análises de propostas e financiamentos habitacionais - antes uma atribuição exclusiva do bando - para concessão de empréstimos.

Em 2009 fazem a segunda oferta pública de ações e arrecadam cerca de R \$722 milhões. Em 2010, o faturamento da empresa atingiu $\mathrm{R} \$ 714$ milhões. Cerca de dez vezes mais do que atingira em 2007 (R\$ 71,6 milhões).

Em 2011, já como líder de contratos do PMCMV, detém a parcela de 12\% dos empreendimentos contratados pelo Programa.

Em 2015 a MRV foi denunciada pelo Ministério Público do Trabalho por submeter seus funcionários a trabalho análogo à escravidão em seus canteiros.

Diferentemente de outras empresas brasileiras do setor que abriram capital, a MRV conseguiu, de certa maneira, se manter estável no período de retração após 2014. Em 2016, 
quando 11 das 17 incorporadoras de capital aberto amargaram prejuízos, a empresa fechou o ano alcançando um lucro de R \$ 557 milhões e investiu cerca de R \$ 41 bilhões em landbank, projetando lançamentos de 60 mil unidades por ano durante um longo período ${ }^{195}$. Em 2017, num período onde as incorporadoras nacionais estavam diminuindo sua atuação em diversos estados brasileiros, a MRV expandiu ainda mais para Região Norte do país. Atualmente a MRV é a incorporadora brasileira de maior valor de mercado na bolsa de valores, atingindo a marca de $\mathrm{R} \$ 6,08$ bilhões, segundo dados da Bovespa.

Gráfico 16. Trajetória da MRV na Bovespa (2007-2016)

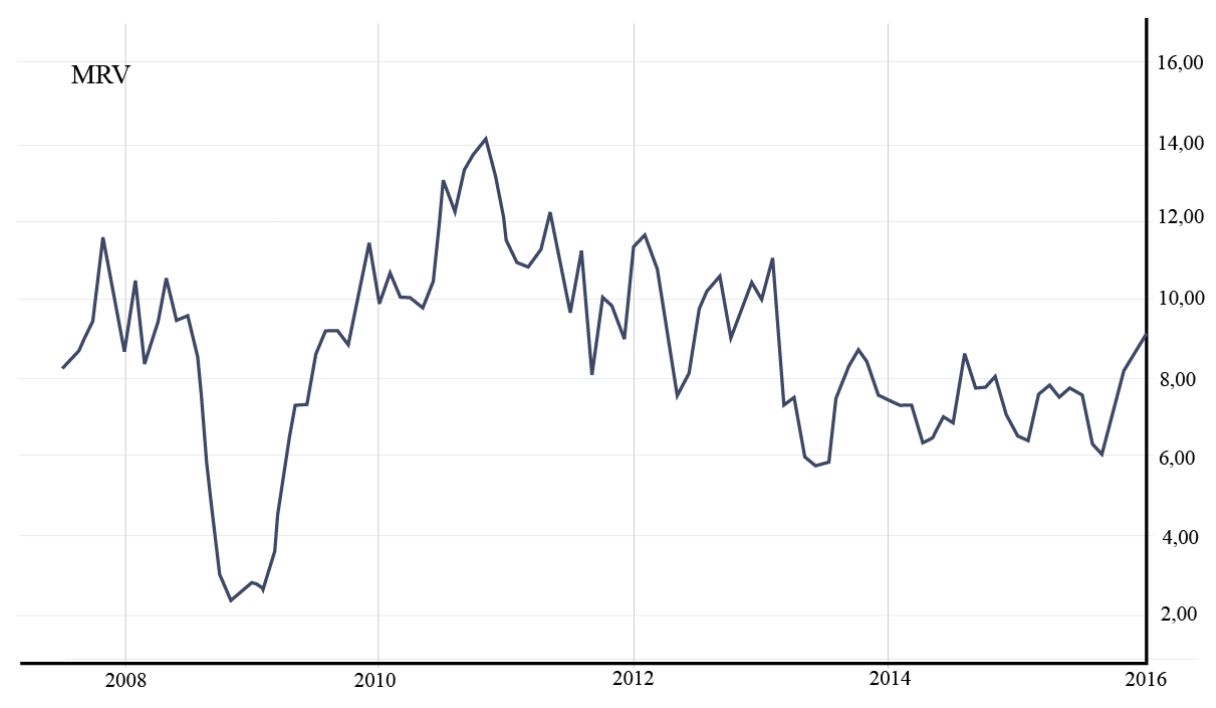

Fonte: elaboração do autor com dados da BM\&F Bovespa

Assim como a Cyrela, a MRV também possui uma estrutura familiar no controle da empresa, centralizada no comando de seu fundador Rubens Menin, que também atua como presidente do Conselho de Administração da ABRAINC. Apesar da MRV ter aberto seu capital e, com isso, sofrer a pressão de investidores para que se expanda seu leque de atuação, seu presidente e principal acionista decidiu manter a sua produção concentrada para o segmento econômico, o que a transformou em líder de contratos do PMCMV, como já mencionado.

Fix (2011) aponta em sua tese que ao final da segunda oferta pública de ações em 2009, a adesão de investidores estrangeiros às ações da MRV foi bastante considerável. $\mathrm{O}$ fundo de investimentos Janus Capital Management, que também já compôs o quadro acionário de outras incorporadoras brasileiras, adquirira 5,7\% das ações. A inglesa Prudential Plc. detinha, até 2017, cerca de 5\% das ações da companhia. Atualmente, a Blackrock Inc.,

195 Conforme matéria "Enquanto uns choram, a MRV pisa no acelerador — Como?" publicada na Exame em 26/04/2017: https://exame.abril.com.br/revista-exame/enquanto-uns-choram-a-mrv-pisa-no-acelerador-como/ 
considerada a maior gestora de ativos (private equity) do mundo e que já compôs o quadro acionário da Cyrela e PDG, adquiriu, em 2018, 5,1\% das ações da MRV.

Tabela 9. Posição acionária da MRV (2018)

\begin{tabular}{lcr}
\hline \multicolumn{3}{c}{ Posição Acionária - MRV } \\
\hline Acionista & Nacionalidade & Ações Ordinárias (\%) \\
\hline Rubens Menin* & Brasil & 33,6 \\
Prudential Plc & Inglaterra & 5,07 \\
Executivos e & - & 2,1 \\
membros do conselho & - & 0,6 \\
Tesouraria & - & 58,7 \\
Outros & &
\end{tabular}

Fonte: Econoinfo

Das incorporadoras analisadas, a MRV é a única que não atuava no Rio de Janeiro antes da abertura de capital. Seus primeiros empreendimentos na cidade foram lançados no bairro de Jacarepaguá em 2007 - os empreendimentos Spazio Regency (88 unid.), Spazio Rennes (160 unid.) e Spazio Rimini (168 unid.) - com características bem distintas dos que viriam a ser produzidos após o lançamento do PMCMV.

Em 2009, com o lançamento do PMCMV, todos os empreendimentos lançados pela MRV se vincularam ao programa e, com isso, a tipologia e o porte dos empreendimentos se modificaram. A MRV passa a ficar marcada por tipologias padrões que se repetem exaustivamente nos empreendimentos para atuação nas Faixas 2 e 3 em todo Brasil e por ter uma maneira bem particular de organização de seus canteiros. Em linhas gerais, são empreendimentos com um grande número de blocos de até cinco pavimentos, sem elevadores, com as áreas livres quase toda destinada a estacionamento e com o mesmo produto arquitetônico, sofrendo poucas alterações de acordo com a implantação de cada projeto.

Segundo os dados da Ademi, a produção da MRV no município do Rio de Janeiro foi bastante irregular no período analisado. Além disso, o número de unidades lançadas pela incorporadora na cidade também não causa espanto. Tal fato pode ser justificado por dois motivos: em primeiro lugar, os relatórios da MRV apontam para uma estratégia de atuação que prioriza o lançamento de empreendimentos em cidades do interior, embora não especifique os estados. Nos anos de 2009, 2010 e 2011, a parcela de lançamentos no “interior” da MRV foram 53\%, 55\% e 47\%, respectivamente, enquanto as parcelas dos 
empreendimentos lançados em "capitais" foram 27\%, 14\% e 23\%. Além disso, o Rio de Janeiro teve uma participação bem mediana nos números de lançamentos da MRV pelo Brasil, apesar de sua importância econômica. Em segundo lugar, essa estratégia de lançamentos em cidades do interior, pode estar relacionada aos altos preços da terra nas principais metrópoles brasileiras. Como já demonstrado em gráfico no início do capítulo 3 , o Rio de Janeiro foi a cidade brasileira onde a variação média do preço da terra foi mais intensa entre 2008 e 2016, a despeito de historicamente a cidade possuir um dos $\mathrm{m}^{2}$ mais caros do país. Nesse sentido, levando-se em consideração o tipo de produto lançado pela MRV e o segmento de renda a quem destina seus produtos, pode ser esta a razão da participação mais acanhada da incorporadora na cidade do Rio de Janeiro em relação a outras cidades, ainda que a atuação da MRV na cidade possa impactar a paisagem.

Gráfico 17. MRV: unidades lançadas por ano no Rio de Janeiro (2007-2015)

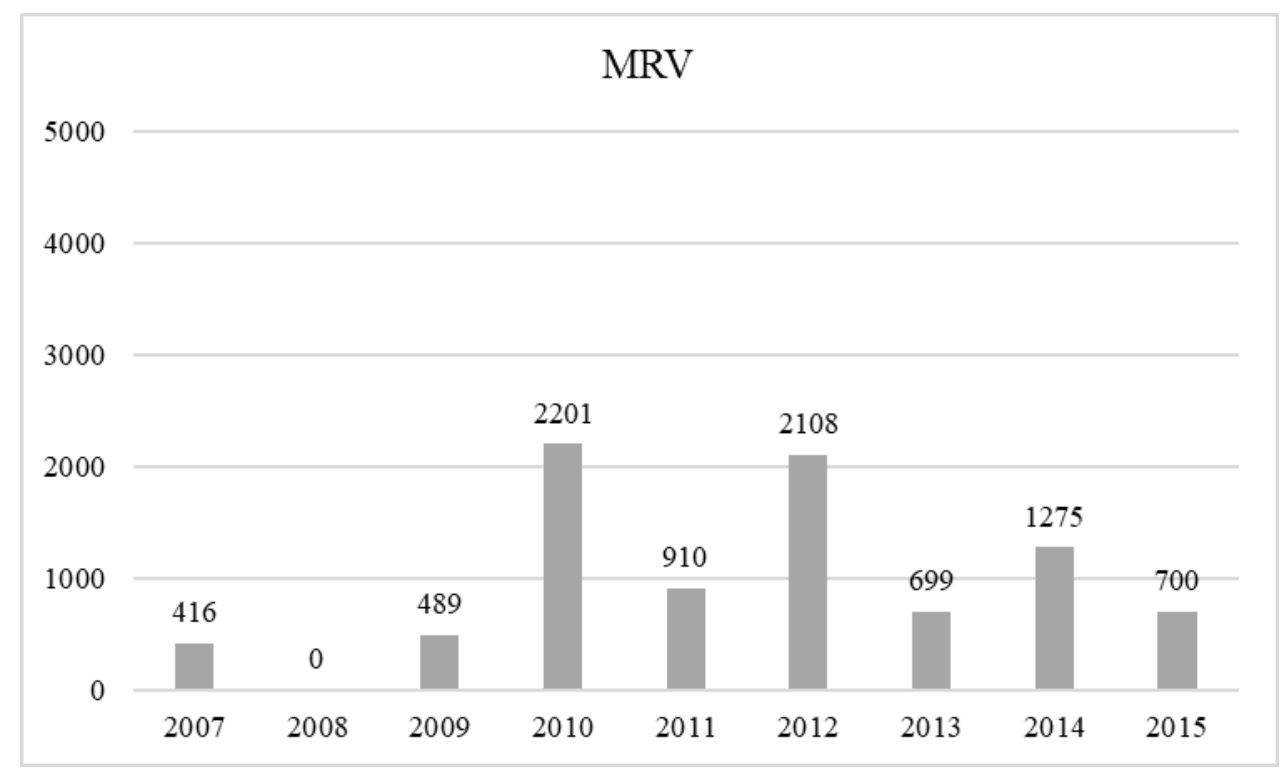

Fonte: elaboração do autor com base em dados da Ademi

Os lançamentos da MRV no território carioca tendem a se concentrar nos bairros menos valorizados da Zona Norte e da Zona Oeste, embora possuam estreita relação com as infraestruturas de mobilidade e principais vias da cidade. A atuação nesses territórios está estreitamente relacionada com o argumento indicado anteriormente. Nessa perspectiva, os empreendimentos que mais chamam atenção é o Recanto dos Pássaros (Rouxinóis, Andorinhas e Beija-Flores) no bairro de Honório Gurgel com 1100 unidades construídas e divididas em três condomínios. Nesta mesma lógica, no bairro vizinho, em Guadalupe, a MRV também lançou o empreendimento Parque Recreio (do Pontal e dos Bandeirantes) com 
600 unidades no total, dentre outros. Essa estratégia de construir diferentes condomínios justapostos ou bem próximos é prática bem comum entre as incorporadoras que atuam para o segmento "econômico", uma vez que a aglomeração dessas construções faz com que a própria incorporadora engendre um processo de capitalização da propriedade imobiliária, além da otimização do canteiro no mesmo espaço, que permite às empresas auferirem maiores lucros na produção imediata.

Outra característica marcante dos empreendimentos da MRV na Zona Norte do Rio, é a relação dos empreendimentos com a Avenida Brasil e com a Supervia como demonstrado no mapa a seguir, embora haja também a relação de alguns empreendimentos com a Linha 2 do Metrô.

Mapa 13. Lançamentos da MRV na cidade do Rio de Janeiro por porte (2007-2015)

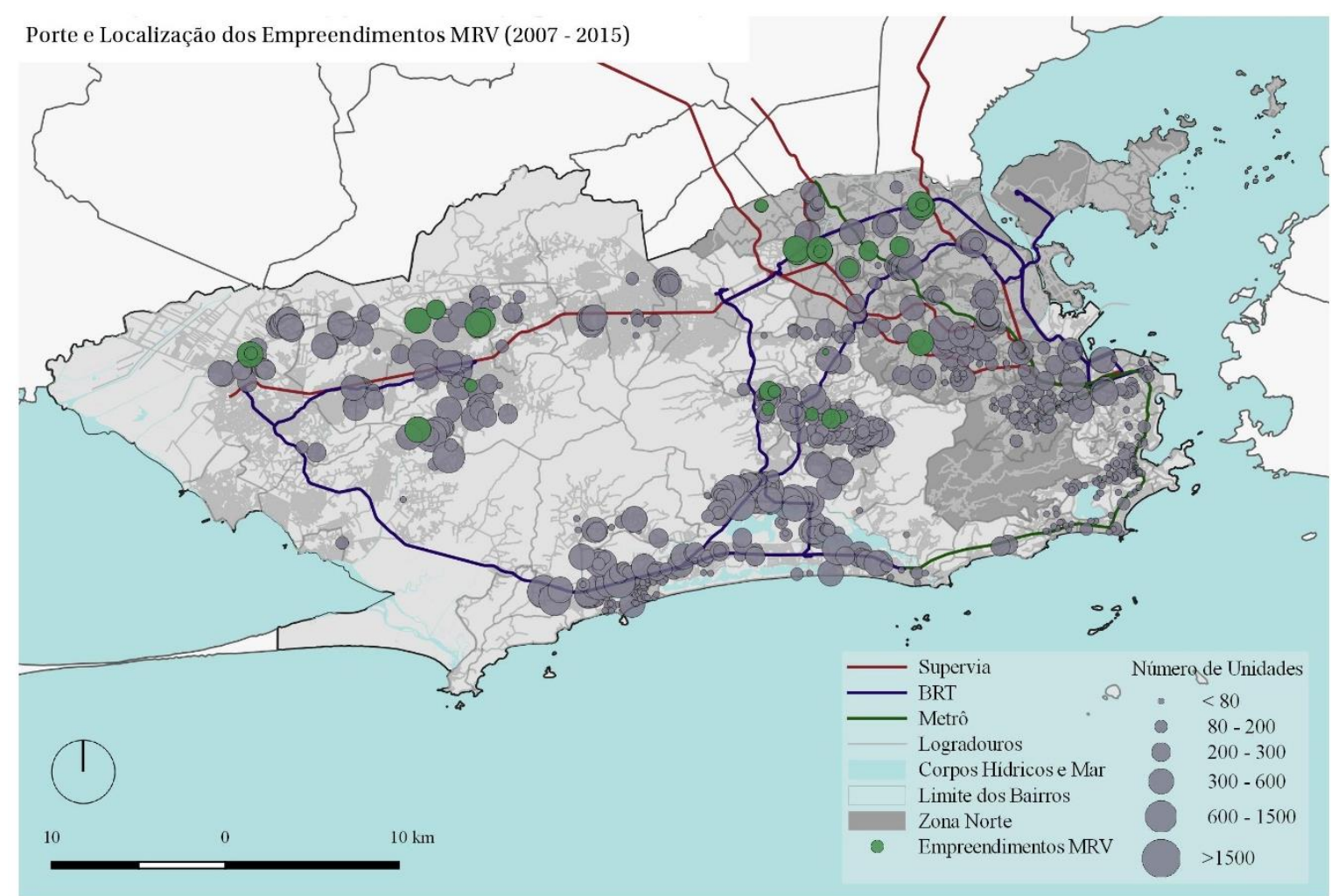

Fonte: elaboração do autor em parceria com Paula C. Moreira a partir de dados da Ademi

\section{PDG: trajetória e estratégia de atuação no Rio de Janeiro}

Das incorporadoras aqui abordadas, a paulistana PDG é a única que surgiu a partir de práticas de gestão financeira, em contraponto às outras empresas originárias de uma estrutura familiar 
de negócios. Por conta disso, considera-se a primeira corporate ${ }^{196}$ do setor no Brasil. Inicialmente, ela se consolidou no mercado brasileiro como uma das principais incorporadoras e construtoras atuando no mercado residencial para faixas de renda de médio e alto padrão, em áreas valorizadas da capital fluminense e paulista, mas também nos segmentos comercial e de loteamentos. Segundo dados disponibilizados em seu site, a incorporadora diz possuir um portfólio de 150 mil unidades entregues desde o início de suas atividades até o final de 2017.

Embora a PDG tenha surgido em 2003 incorporada ao fundo de investimento e participações Pactual Desenvolvimento e Gestão I, sua origem remonta ao ano de 1998 quando surge, na cidade de São Paulo, a Varsóvia Participações S/A, uma holding patrimonial ${ }^{197}$ que atua no setor imobiliário, fundada por executivos do Banco Pactual. Apesar disso, "a PDG se apresenta como uma empresa com 40 anos de experiência, justamente porque resulta de uma sequência de aquisições de empresas antigamente de estrutura familiar" ${ }^{198}$.

Apenas em 2006 a PDG torna-se uma unidade de negócios independentes e já em janeiro de 2007 abre seu capital na bolsa de valores (Bovespa), captando R \$ 648 milhões no seu I.P.O. e mais R $\$ 575$ milhões no Follow $O n^{199}$ poucos meses depois. A maior parte das ações $(40,1 \%)$ ficaram sob gestão do fundo de investimento fundador e o restante com outros fundos e acionistas minoritários. Para se ter uma ideia do impacto gerado nos números da PDG devido à captura de recursos via mercado financeiro, apenas nos nove primeiros meses a empresa teve um crescimento de $379 \%$ em seu VGV para o ano. O que se vê a partir disso é uma sucessiva entrada de grandes fundos de investimentos internacionais na composição acionária da empresa, adquirindo boa parte de suas ações em um dado momento e as vendendo quando lhes é oportuno.

Passado o processo de abertura de capital e tendo que expandir sua atuação geográfica e para outros segmentos de faixa de renda para aumentar consideravelmente seus ganhos e mostrar resultados para os investidores, a PDG partiu em busca de adquirir outras empresas. Em

\footnotetext{
196 Empresa com princípios de governança corporativa, diferenciando-se das empresas de estrutura familiar que tem a figura do(s) dono(s).

${ }^{197}$ Holding Patrimonial é uma empresa criada para administrar bens patrimoniais familiares ou próprios imóveis na maior parte das vezes - visando facilitar a gestão dos mesmos e atuando na compra, venda e locação deles.

${ }^{198}$ FIX, 2011, p. 158

${ }^{199}$ O Follow On caracteriza-se como um processo onde uma empresa de capital aberto volta ao mercado de ações para disponibilizar mais papéis com a finalidade de se capitalizar ainda mais, o que acarreta como consequência, a ampliação de sua composição acionária.
} 
2008, integralizou a compra da Goldfarb, empresa que atuava no segmento econômico, e da carioca CHL. Em 2010 adquiriu a Agre, empresa que já tinha forte atuação em São Paulo e nas regiões Norte e Nordeste.

Em 2011 faz a fusão dessas empresas numa única marca, a PDG, que passa a significar "Poder de Garantir". Neste ano, a incorporadora atinge o valor de mercado de R $\$ 11$ bilhões, tornando-se a maior incorporadora do Brasil, tanto em VGVs alcançados e número de unidades lançadas. Além disso, a PDG já lançava empreendimentos em 15 estados, no Distrito Federal e até mesmo na Argentina. A partir de 2012, no entanto, a empresa entra numa derrocada devido a denúncias de corrupção e brigas envolvendo seus diretores. Seguindo esse declínio, em 2015, a PDG acumulava prejuízos e dívidas acima de R\$ 1 bilhão, vendo suas ações serem negociadas pelo preço de $\mathrm{R} \$ 0,09^{200}$. O gráfico abaixo mostra a performance da incorporadora na bolsa desde 2007:

Gráfico 18. Trajetória da PDG na Bovespa (2007-2016)

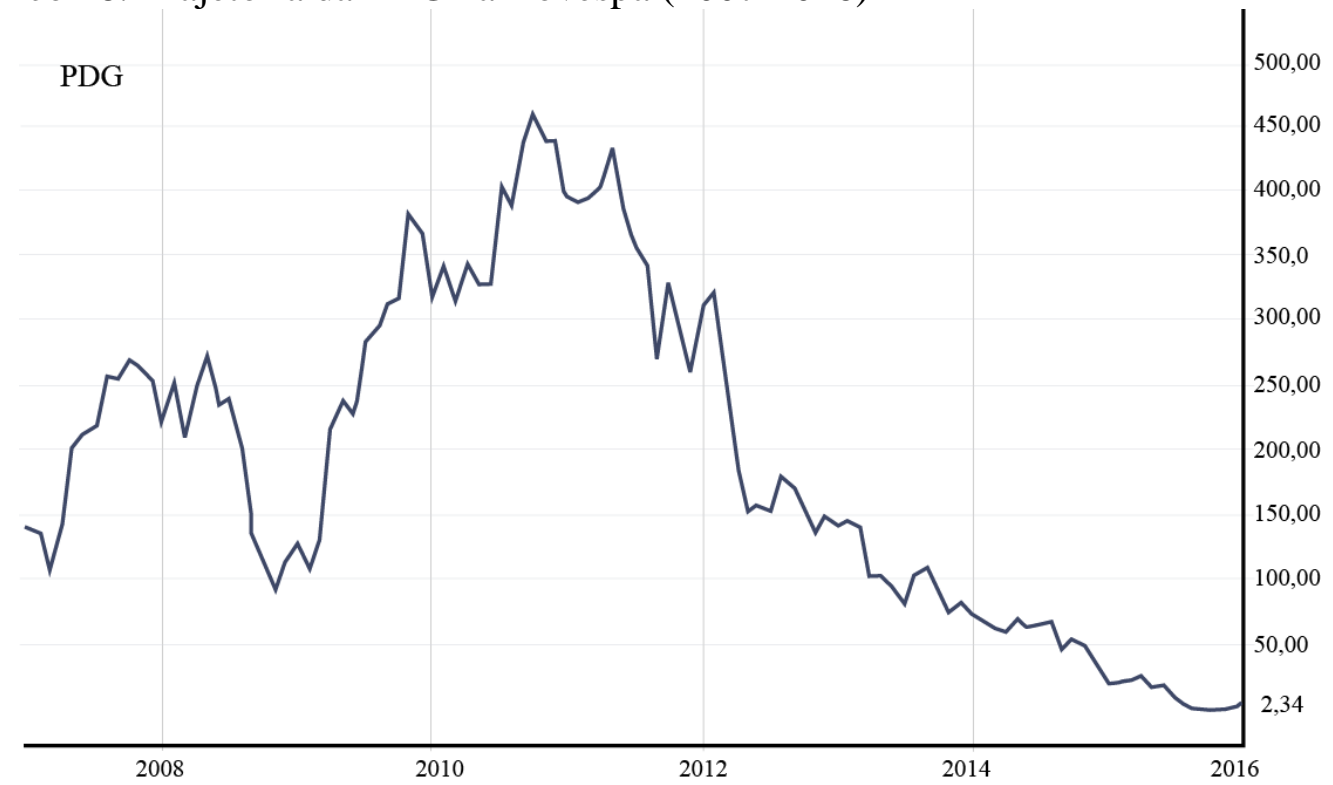

Fonte: elaboração do autor com dados da BM\&F Bovespa

Com a venda de ações no mercado financeiro em 2007, a PDG ficou sem capital controlador, mas sob a administração dos antigos acionistas, ex-sócios do Banco Pactual, por meio do Fundo de Investimento Vinci Partners. Na PDG, os membros do conselho detinham apenas uma pequena parte das ações, o que em tese não garantiria um efetivo compromisso dos gestores com a saúde financeira global da empresa. Neste contexto de crise, com as ações

200 Conforme matéria "PDG afunda $25 \%$ e ação vale menos de 10 centavos" veiculada na Exame em 24/08/2015. https://exame.abril.com.br/mercados/pdg-afunda-25-e-acao-vale-menos-de-10-centavos/ 
em baixa a Vinci Partners retorna como a principal acionista da PDG com mais um aumento de capital da companhia. A posição acionária atual da PDG, distribuída entre 11.995 investidores "pessoa física”, 125 "pessoa jurídica" e 211 investidores institucionais ${ }^{201}$, conforma-se da seguinte forma:

Tabela 10. Posição acionária da PDG (2017)

\begin{tabular}{lcr}
\hline & Posição Acionária - PDG & \\
\hline Acionista & Nacionalidade & Ações Ordinárias (\%) \\
\hline $\begin{array}{l}\text { Vinci Equities Gestora } \\
\text { de Recursos }\end{array}$ & Brasil & 22,38 \\
$\begin{array}{l}\text { Orbis Investment } \\
\text { Management }\end{array}$ & Bermuda & 15,11 \\
Vinci Capital Partners II & Brasil & 11,66 \\
Outros & - & 50,85 \\
\hline
\end{tabular}

Fonte: Econoinfo

Após a abertura de capital na bolsa, a PDG adotou uma postura agressiva no mercado para atender a demanda de seus acionistas. Para isso, intensificou a sua produção (12.860 unidades em 2007 para 42.616 em 2010) ${ }^{202}$ em diversos segmentos de faixa de renda, em especial o "econômico", adquirindo e lançando novos empreendimentos em áreas periféricas das principais metrópoles brasileiras. Antes da abertura de capital, a atuação da PDG no segmento "econômico" era bastante modéstia, dando ênfase aos segmentos "médio", "médio-alto" e "alto". A partir de 2007, com a urgente necessidade de expansão, passa a priorizar seus lançamentos no segmento "econômico" e, com o lançamento do PMCMV, a atuação nesse segmento ganha um boost e passa a representar mais de $80 \%$ do portfólio de unidades lançadas. A partir de 2012, com a empresa em crise e a diminuição significativa de lançamentos pelo país, a PDG diminui sua atuação geográfica pelo país e volta seus lançamentos para faixas de renda que tradicionalmente o mercado imobiliário sempre priorizou antes do boom. O gráfico abaixo revela a heterogeneidade dos lançamentos da PDG durante o período entre 2005 e 2015 :

\footnotetext{
${ }^{201}$ Dados atualizados pela última vez em 19/09/2017, pelo site Econoinfo.

${ }^{202}$ Segundo dados dos relatórios de resultados trimestrais da PDG
} 
Gráfico 19. Série histórica de lançamentos da PDG por segmento de mercado

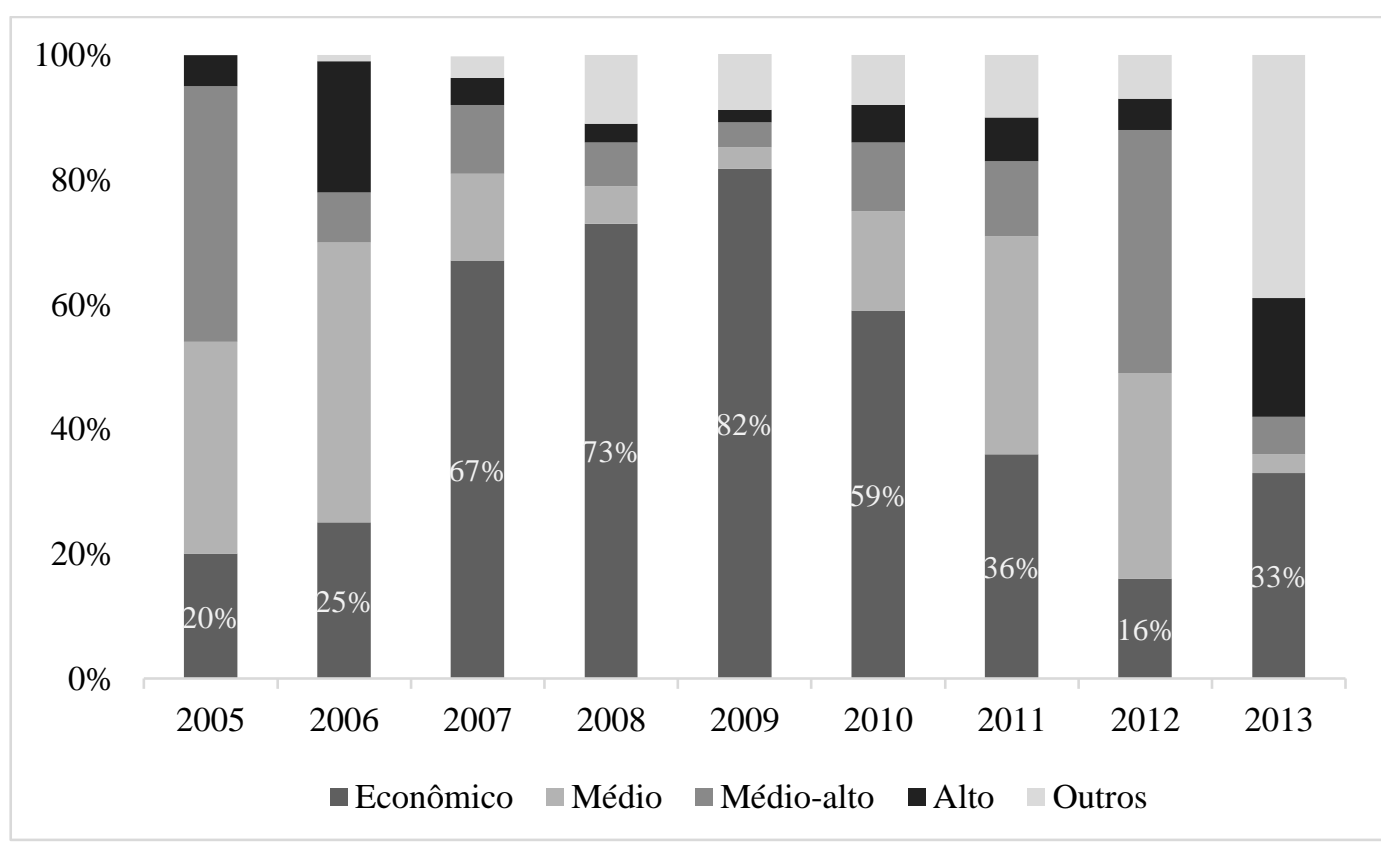

Fonte: elaboração do autor a partir de dados dos relatórios de resultados anuais da PDG

A PDG passou a atuar no Rio de Janeiro a partir da compra de parte da CHL, construtora carioca com largo know-how em segmentos de "médio-alto" e "alto" padrão, com forte atuação na Zona Sul. No início de 2007, adquiriu 40\% da empresa e, até o final do mesmo ano, já detinha $70 \%$ e, em 2008, fez a aquisição de $100 \%$ da mesma. A compra da CHL implicou também na aquisição de seu landbank e de todo seu know-how e portfólio. A partir disso, alinhavou uma parceria entre a Goldfarb e a CHL para atuação no segmento "econômico" na cidade, aliando a expertise no segmento de uma ao domínio e influência no território carioca da outra. Além disso, a CHL foi importante para a manutenção de lançamentos de médio-alto e alto padrão na cidade, embora com bem menos frequência.

Entre 2000 e 2006, ainda como CHL, os empreendimentos lançados na cidade do Rio de Janeiro mantinham o histórico padrão de produção para uma demanda solvável nos bairros da Zona Sul. Esses Empreendimentos eram de pequeno e médio portes, com algumas dezenas de unidades e não ultrapassando 150 de uma maneira geral, com uma média de preços por unidade de aproximadamente $\mathrm{R} \$ 500$ mil. Os pontos fora da curva desse período e que já apontam para uma expansão geográfica e o aumento considerável de seus empreendimentos, são três lançamentos no Catete, na Freguesia e no Engenho de Dentro: Quartier Carioca (880 unid.), Aquarius Residencial (348 unid.) e o Arena Park (989 unid.), respectivamente. O primeiro caso, ainda localizado na Zona Sul, causa certo espanto pelo 
gigantismo do empreendimento numa região quase saturada e com terrenos extremamente fragmentados e de preços elevados. Os outros dois já apontam para uma expansão geográfica e de outro patamar de porte, que se tornará o padrão de lançamentos da PDG no período seguinte.

Mapa 14. Lançamentos da PDG na cidade do Rio de Janeiro por porte (2000-2006)

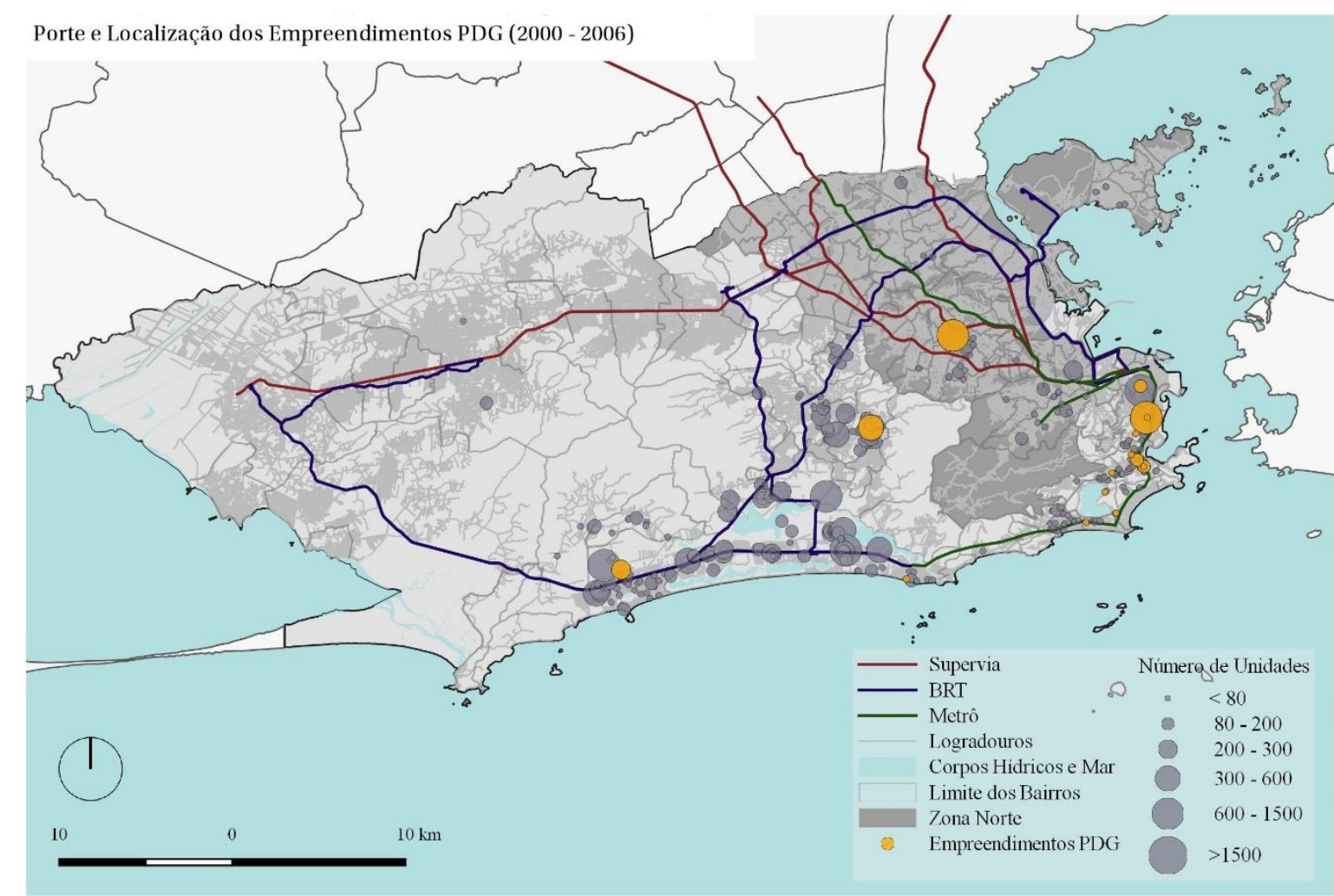

Fonte: elaboração do autor em parceria com Paula C. Moreira a partir de dados da Ademi

A partir da abertura de capital em 2007, tornou-se bastante perceptível a intensificação da atuação da incorporadora na cidade do Rio de Janeiro. Conforme divulgado em relatório de resultados em 2011, 16,5\% dos lançamentos da empresa foram na capital fluminense. Ficando apenas atrás de São Paulo (capital) e "demais cidades" do estado paulista. Entre 2007 e 2015, foram lançadas cerca de 15.800 unidades pela PDG, predominantemente residenciais para o segmento "médio" e "econômico". Este último intimamente ligado ao PMCMV, mas também empreendimentos de "alto" e "médio-alto" padrão na Zona Sul e edifícios comerciais, embora numa escala menor. 
Gráfico 20. PDG: unidades lançadas por ano no Rio de Janeiro (2007-2015)

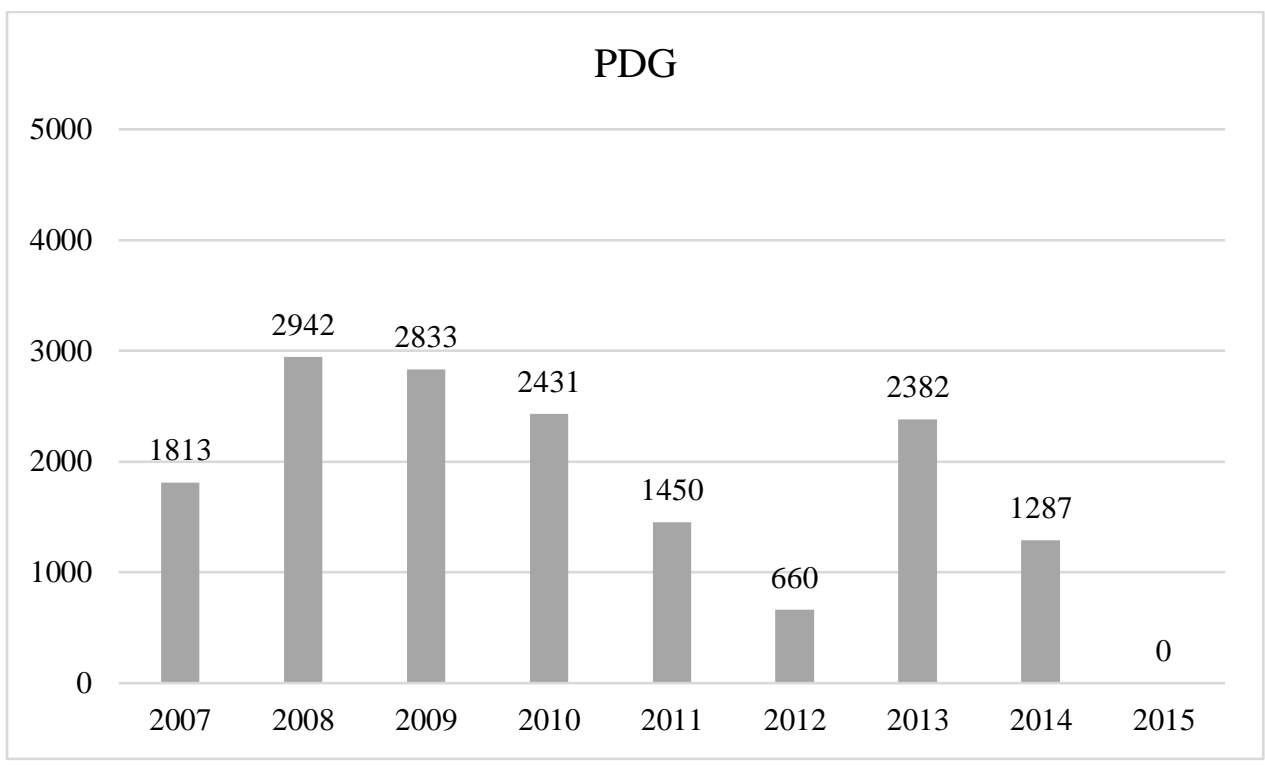

Fonte: elaboração do autor com base em dados da Ademi e de relatórios da PDG

A maior incidência dos empreendimentos lançados no período encontra-se na Zona Norte da cidade, articulados com as novas e antigas infraestruturas de mobilidade, como os BRTs, a Linha 2 do Metrô, os ramais da Supervia e até mesmo à Linha Amarela - via expressa que liga a Av. Brasil à Barra da Tijuca. A construção dessas novas infraestruturas somadas a uma nova legislação urbanística que incentiva a intensificação e o adensamento construtivo do entorno dessas áreas, torna-se a condição central para que os novos lançamentos alcancem altos preços e rápida liquidez.

O tamanho dos empreendimentos também é importante ser analisado, uma vez que para se alcançar o lucro e rentabilidade almejados pela incorporadora e seus acionistas, os empreendimentos em áreas menos valorizadas devem necessariamente ter um grande porte para atingir o VGV estipulado, já que o "baixo" preço por unidade comercializado nessas áreas precisa ser compensado pelo grande número de unidades.

Como estratégia geral, a PDG apostou na força de sua marca para realizar seus empreendimentos, organizando todas as etapas de incorporação dentro da empresa e quase sempre sem a realização joint ventures com outras parceiras, seja no segmento econômico ou no alto padrão. Como aponta Faulhaber (2015), "Os poucos casos de parceria de incorporação estão majoritariamente localizados na região da Barra da Tijuca e Jacarepaguá 
e ocorrem principalmente com firmas ou grupos de investimentos locais, que por vezes, representam os proprietários de terras"203.

Mapa 15. Lançamentos da PDG na cidade do Rio de Janeiro por porte (2007-2015)

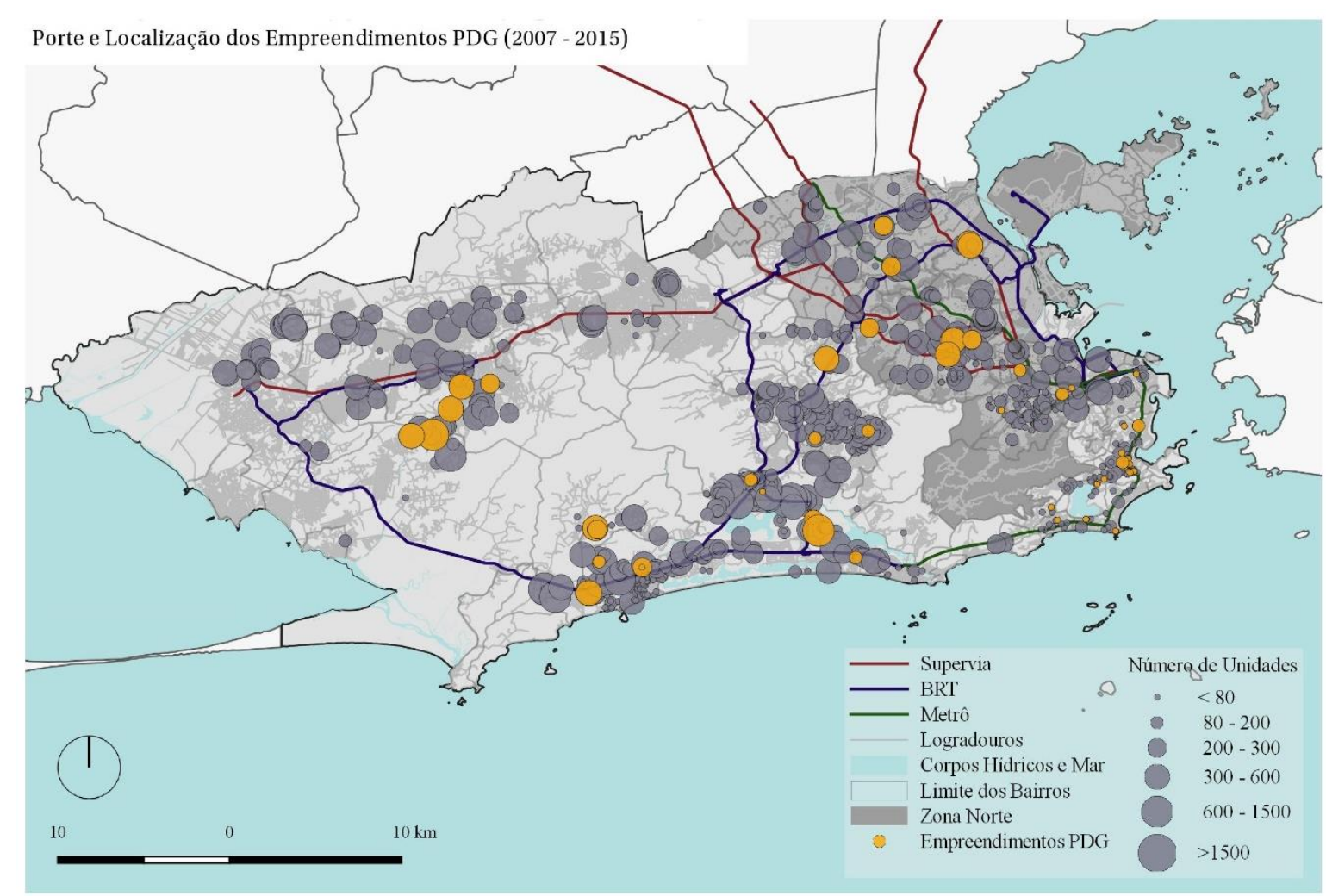

Fonte: elaboração do autor em parceria com Paula C. Moreira a partir de dados da Ademi

A análise da trajetória e estratégia de atuação dessas empresas no território carioca, suscita questões de cunho teórico já explicitadas anteriormente e que torna fundamental a sua retomada à luz desses processos concretos anteriormente expostos. Trata-se dos limites e contradições que o próprio modo de produção capitalista impõe à concentração e centralização do capital nas empresas do setor imobiliário que, como já comentado, tem particularidades frente a outros setores da indústria. Nesse sentido, a terra aparece como questão central para compreender esse processo.

Tendo em vista que o imbricamento entre o capital financeiro e o setor imobiliário se apresenta, do ponto de vista das formas de produção, a relação mais desenvolvida do ponto

${ }^{203}$ FAULHABER, 2015, p. 69 
de vista da reprodução e acumulação do capital na produção do espaço, imaginou-se, à princípio, com o aumento exponencial dessas empresas num curto espaço de tempo no que diz respeito a seus respectivos volumes de produção, de concentração de capital e dos exorbitantes lucros alcançados, que a abertura de capital na bolsa de valores fosse o caminho "natural" para as incorporadoras que quisessem crescer e expandir. Contudo, como apontado em estudo produzido por Penha Filho e Mioto (2017), "a partir de 2012, nota-se uma reversão desse movimento [de crescimento], colocando novas questões sobre a dinâmica setorial e sua relação com o mercado de capitais" ${ }^{204}$. Em outras palavras, essa ascensão meteórica seguida, pouco tempo depois, da crise de algumas dessas empresas, coloca em dúvida a sustentabilidade deste modelo calcado na captura de recursos via mercado financeiro.

Analisando os gráficos de performance dessas empresas na bolsa, nota-se que a partir de 2011 todas elas passam a ter o preço de suas ações comprometidas. Essa crise pode ser evidenciada também pelos relatórios trimestrais disponibilizados pelas empresas para seus acionistas e para o mercado em geral, onde o número de empreendimentos lançados tem uma queda significativa, recuo na expansão geográfica para outros estados brasileiros e seus ativos, como banco de terrenos, passam a ser negociados antes mesmo da promoção de novos lançamentos. Um claro sintoma de que a saúde financeira dessas empresas não estava indo bem.

O que se nota a partir desse cenário é uma mudança nas estratégias de atuação dessas grandes incorporadoras e até mesmo a forma como os investidores analisam o desempenho das mesmas: se antes um portfólio com um landbank robusto indicava a realização futura de novos empreendimentos, sinalizando ao mercado a oportunidade de aumento de seus rendimentos, após a crise no setor, a velocidade com que as incorporadoras se desfazem de seus estoques de unidades não comercializadas torna-se o indicador de saúde financeira e, consequentemente de segurança no investimento.

Além disso, as empresas que apostaram na diversificação de produtos para diversos segmentos e na expansão geográfica, como as já comentadas Cyrela e PDG, "voltam suas atividades aos mercados mais dinâmicos do país, como São Paulo Capital e Interior além de Rio de Janeiro e alguns estados do sul e desfazem-se também de empresas adquiridas" 205.

\footnotetext{
204 PENHA FILHO e MIOTO, 2017, p. 04

${ }^{205}$ Ibid., pp. 14-15
} 
Nessa lógica, quando se analisa a produção dessas metrópoles no período pós crise, percebese que essas grandes empresas voltam a adotar as mesmas estratégias do período anterior ao estudado, lançando seus empreendimentos nas áreas mais valorizadas dessas metrópoles, mas também atuando, como no caso da PDG, em outras segmentos que não o residencial como as de galpões para indústria e logística. No ano de 2013 a maior parcela da produção da empresa $-39 \%$ - se deu justamente nesses segmentos.

A MRV, por sua vez, tem uma performance diferente das outras empresas no momento de crise. A incorporadora expandiu a sua atuação para quase todos os estados brasileiros, sobretudo para cidades médias e bairros das periferias das grandes metrópoles, mas manteve restrita sua atuação no segmento de mercado que atuara desde sempre e que, por isso, detinha bastante expertise: o econômico. A produção, quase toda vinculada ao PMCMV, fez da MRV a líder em contratos do programa, como já mencionado, e essa característica foi fundamental para manter a empresa afastada da crise que abateu as incorporadoras de capital aberto a partir de 2012. Isso pode ser constatado pela pouca variação do preço de suas ações na bolsa conforme o gráfico da performance da empresa na Bovespa. Além disso, a MRV foi a única dentre as empresas estudadas que, mesmo no momento de crise econômica no setor e no país, ampliou seu landbank, demonstrando que a expansão da produção não será interrompida. Essa trajetória de estreita relação entre a MRV e o PMCMV ilustra com bastante clareza a atuação do Estado como um importante agente nesse processo pois, ao fornecer subsídios tanto à produção como ao consumo, garante a reprodução ampliada do capital e, consequentemente, a acumulação na esfera financeira.

Embora alguns estudos apontem que a crise financeira enfrentada pelas grandes incorporadoras brasileiras de capital aberto se resuma a problemas de gestão, onde apostouse numa rápida expansão geográfica sem o domínio necessário das dinâmicas particulares dos mercados locais e na atuação para diversos segmentos de renda fora de seus respectivos know-how, e até mesmo à crise política e econômica que se instalou no Brasil a partir de 2014, defende-se aqui uma outra visão que dialoga com a ideia de que a intensificação do processo de capitalização do preço da terra e, consequentemente, dos imóveis, muito em decorrência da própria insaciabilidade do capital financeiro em auferir maior rentabilidade a partir dos investimentos realizados torna-se o próprios obstáculo para a reprodução ampliada do capital a partir do imobiliário, deixando claro seus limites. 
Gráfico 21. Variação da valorização (\%) do preço dos imóveis no Rio de Janeiro x performance da Bovespa entre 2008 e 2015

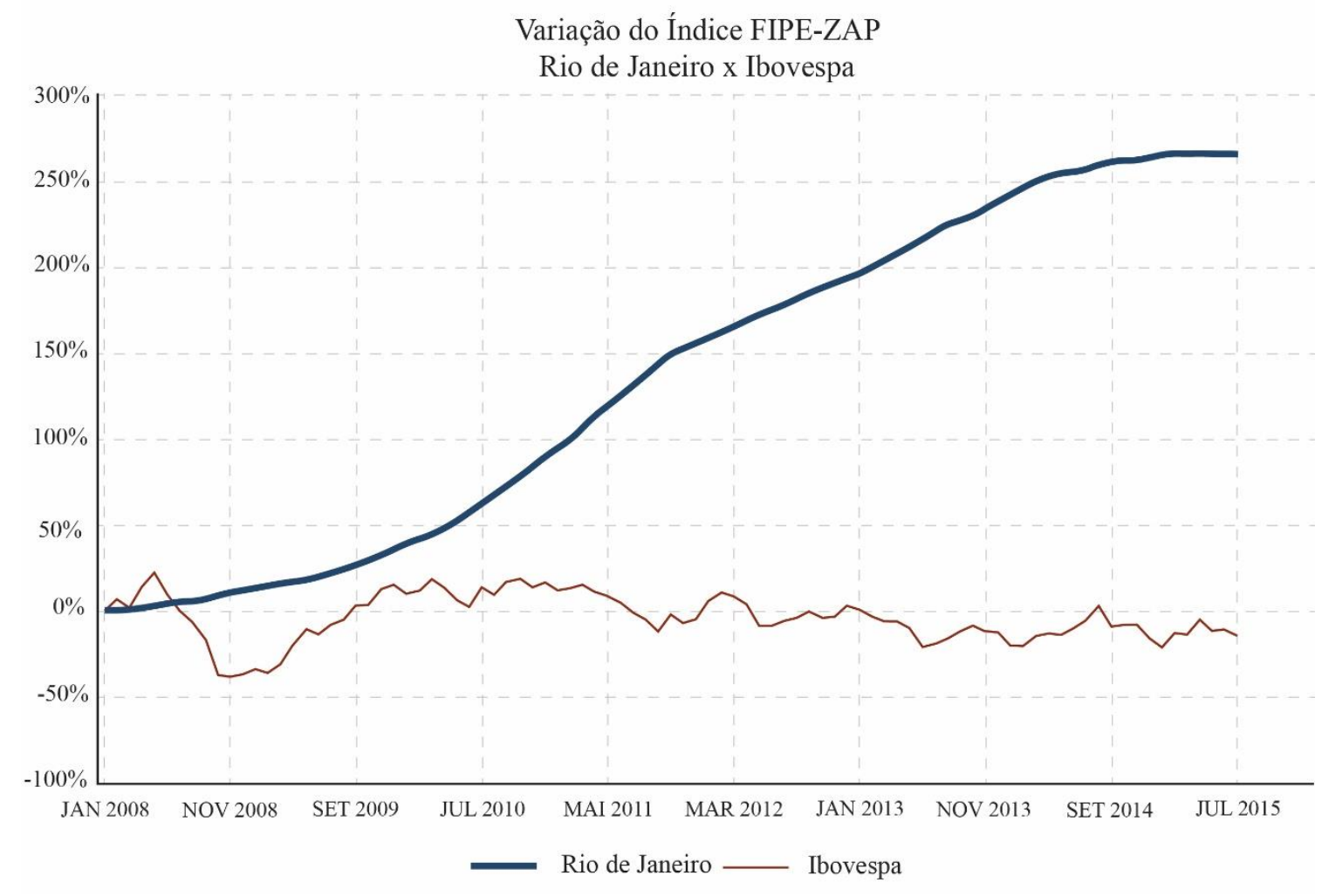

Fonte: FIPE-ZAP

Se num primeiro momento a terra é vista como um obstáculo à produção imobiliária, pois atuando como um falso custo onde se imobiliza capital para sua aquisição antes mesmo da produção, ela passa a ser um impulso para acumulação a partir da capitalização da renda imobiliária, possibilitando auferir ganhos ainda maiores a partir desse processo. Porém o que se vê nesse período de intensa expansão é um aumento cada vez mais insano dos preços da propriedade imobiliária. Nesse sentido, ela mesma se torna um entrave para a aquisição de novos terrenos, para a produção e no circuito do consumo, já que a renda dos trabalhadores brasileiros, ainda que tenha adquirido aumento real no mesmo período, não acompanhou o mesmo ritmo observado na variação dos preços imobiliários. 


\section{CONSIDERAÇÕES FINAIS}

A produção imobiliária a partir da lógica financeira, operando todo o espaço das metrópoles enquanto lócus de reprodução ampliada do capital, atinge seu apogeu na contemporaneidade, causando repercussões em todos os âmbitos da vida social. A "insaciabilidade" inerente às finanças associada ao imobiliário, vem tornando cada vez mais insana a oscilação de preços das propriedades imobiliárias, à medida que se expande para todos os espaços das metrópoles, intensificando os processos de exploração do trabalho, mas também de espoliação imobiliária, uma vez que os preços de mercado da mercadoria imobiliária - e até mesmo o aluguel - torna-se inviável para a maioria dos trabalhadores brasileiros que vivem nessas grandes metrópoles.

O que se revela a partir do presente trabalho é que esse imbricamento torna-se a forma de produção mais avançada do ponto de vista da acumulação capitalista, consolidando uma intensa generalização da forma-condomínio em todos os espaços da metrópole carioca e, com isso, produzindo mais precariedade e desigualdade socioespacial. Marx já apontava no século XIX que "quanto mais rápida a acumulação capitalista, tanto mais miseráveis são para os trabalhadores as condições habitacionais" ${ }^{206}$. Tal fato, num primeiro momento, pode parecer paradoxal, contudo a indústria da construção civil opera a partir de lógicas particulares e distintas de outros setores produtivos da economia cujo aumento da produtividade reduz o preço de produção das mercadorias. No imobiliário, ao contrário, a generalização da mercadoria habitação promove o encarecimento de seu preço devido à necessidade do pagamento de uma renda de monopólio a seu proprietário, acarretando, nesses momentos de expansão, a elevação da mesma que se capitaliza continuamente, conforme demonstrado. A intensificação da propriedade imobiliária como capital fictício na atualidade agrava ainda mais essa situação.

As metrópoles contemporâneas e, mais especificamente as localizadas na América Latina, foram historicamente constituídas a partir de processos de segregação socioespacial, cuja produção desigual do espaço se caracteriza pela coexistência de formas de produção mais "atrasadas" com formas mais "avançadas" sem que isso constitua na eliminação da primeira. Pelo contrário, a ascensão da segunda se impulsiona a partir da primeira num processo desigual e combinado. Nesse contexto, o papel da produção imobiliária passa a ser

${ }^{206}$ MARX, [1867] 2013, p. 732 
determinante na "organização socioespacial da metrópole, apropriando-se de um padrão histórico de segregação e revigorando-o para obter redução de custos e, simultaneamente, mais rentabilidade por meio da intensificação de uso em terrenos mais baratos" ${ }^{207}$. Dessa forma, a generalização da forma-condomínio para todos os espaços da cidade sob a lógica imperativa da acumulação capitalista financeira não reduz as diferenciações socioespaciais, mas, ao contrário, as intensifica, uma vez que os ganhos auferidos nessa produção "se dá pela redefinição da segregação com elevação do gradiente de preços" ${ }^{208}$. Com isso, intensifica-se os processos segregadores de homogeneização, fragmentação e hierarquização, indicando uma apropriação seletiva do espaço e revelando uma sobreposição desigual de camadas temporais de urbanização: das favelas, das indústrias, dos conjuntos habitacionais, das casas proletárias e dos grandes condomínios.

Nesse sentido, o espaço urbano do Rio de Janeiro é bastante emblemático como síntese dessas contradições socioespaciais inerentes à urbanização capitalista pois observa-se formas de produção extremamente avançadas do ponto de vista capitalista a partir da conexão com as finanças mundiais que se materializam no espaço através de grandes condomínios, ao mesmo tempo em que se constata uma ocupação espacial com aquilo que há de mais precário. Em Sobre a Questão da Moradia, Engels já apontava que "numa sociedade desse tipo, a escassez de moradia não é um acaso; é uma instituição necessária" ${ }^{209}$. Contudo, observa-se na atualidade, frente a um quadro de precariedade que se intensifica, características que delineiam novos processos de espoliação. No período urbano-industrial, esse quadro se consolidou pela negação de serviços urbanos essenciais para a reprodução da classe trabalhadora, onde a aglomeração em favelas a partir da produção doméstica, na maioria dos casos, foi a solução encontrada para sobrevivência. Na atualidade, esses processos espoliativos se juntam ao primeiro, mas adquire duas novas feições que intensificam esses processos - a financeira e a imobiliária. No primeiro caso, a partir do endividamento das famílias numa sociedade baseada no crédito financeiro e pela privatização dos serviços públicos, cujo acesso se dá mediante à contratação desses serviços. Já a espoliação imobiliária se intensifica a partir do momento em que a propriedade imobiliária passa a ser mediada pelas especulações financeiras, reforçando sua característica

\footnotetext{
${ }^{207}$ RUFINO e PEREIRA, 2011, p. 17

${ }^{208}$ Ibid., p. 18

${ }^{209}$ ENGELS, [1872] 2015, p. 71
} 
fictícia. No interior desta lógica, observa-se vertiginoso encarecimento da mercadoria habitação, alijando a existência da classe trabalhadora na metrópole.

Como já demonstrado, o processo de reestruturação imobiliária ocorrido no Rio de Janeiro há pouco tempo, elevou a taxa de valorização média do preço dos imóveis em $360 \%$, registrado em janeiro de 2015. A maior variação dentre as cidades brasileiras.

O alcance dessa taxa não seria possível sem a atuação do Estado em seus diferentes níveis federativos através dos já mencionados mecanismos de capitalização, de caráter jurídicofinanceiro relacionados à disponibilidade de financiamentos e ao PMCMV no âmbito nacional e, no contexto urbano local, através de mecanismos socioespaciais ligados à produção imediata do espaço, viabilizados através de políticas públicas municipais e obras de infraestrutura que foram apropriadas de maneira privilegiada pelas grandes incorporadoras como estratégia de reprodução ampliada do capital através da realização de elevados preços a partir da expansão das fronteiras de acumulação para áreas que até então pouco era exploradas, como a Zona Norte suburbana, no caso da metrópole carioca.

Mapa 16. Preço médio do $\mathrm{m}^{2}$ no município do Rio de Janeiro por bairros (2015)

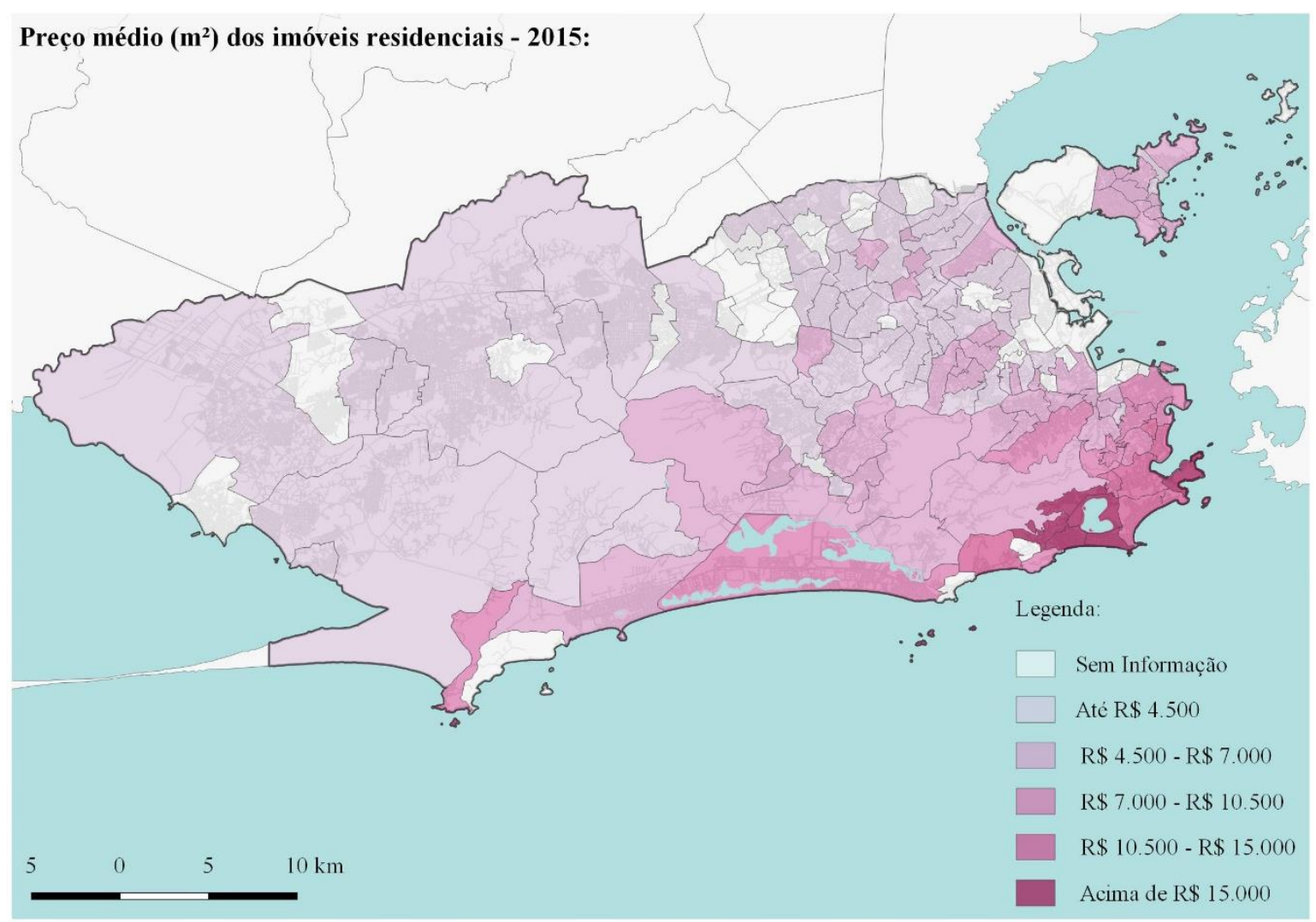

Fonte: elaboração própria com base em dados do Fipe-Zap através de consulta realizada em fev/2018 
O mapa anterior revela como resultado de todos esses processos os altos preços médios do $\mathrm{m}^{2}$ dos imóveis na cidade do Rio de Janeiro no ano de 2015, quando o setor imobiliário já se encontrava em recessão. Atualmente, num cenário de crise política e econômica em âmbito nacional, intensificado ainda mais na metrópole carioca, os preços dos imóveis na cidade diminuíram timidamente, ainda que uma boa parte dessa produção não tenha se realizado na circulação e continue vazia. Um novo patamar de acumulação a partir da valorização e capitalização imobiliária foi alcançado por meio dos imperativos financeiros.

Nesse sentido, a problemática habitacional permanece, na atualidade, longe de ser resolvida. Ao revés, se aprofunda ainda mais. As tentativas de políticas públicas habitacionais operadas pelo Estado capitalista fracassam, pois são instituídas a partir da lógica da valorização do valor. Urge então a necessidade coletiva de questionamento e ações práticas e radicais de antivalor que desafie a instrumentalização da propriedade privada da terra nesta sociedade que tem na desigualdade, a sua premissa e resultado. 


\section{REFERÊNCIAS BIBLIOGRÁFICAS}

ABRAMO, Pedro. Análise das Transações Imobiliárias na Cidade do Rio de Janeiro, no Período 1968-1995. In: Coleção Estudos Cariocas. Secretaria Municipal de Urbanismo: Rio de Janeiro, 2001.

ABREU, Maurício de. Evolução Urbana do Rio de Janeiro. Rio de Janeiro: Instituto Pereira Passos, 2008.

A Periferia de Ontem: o processo de construção do espaço suburbano do Rio de Janeiro (1870-1930). Revista Espaço \& Debates, ano VII, v.1, no 21. 1987.

AGLIETTA, Michel. Regulación y Crisis del Capitalismo. $3^{\mathrm{a}}$ ed. México: Siglo Veintiuno Editores, 1986.

AMARAL, Marisa. Teorias do Imperialismo e da Dependência: a atualização necessária ante a financeirização do capitalismo. Tese de doutorado. FEA-USP. São Paulo, 2012.

ASSOCIAÇÃO BRASILEIRA DE INCORPORADORAS IMOBILIÁRIAS (ABRAINC). Análise das Necessidades Habitacionais e suas Tendências para os Próximos Dez Anos. Relatório Técnico Final. São Paulo: FGV, 2018.

BOTELHO, Adriano. O Financiamento e a Financeirização do Setor Imobiliário: uma análise da produção do espaço e da segregação socioespacial através do estudo do mercado de moradia na cidade de São Paulo. Tese de Doutorado. FFLCH-USP. São Paulo, 2005.

CARDOSO, Adauto. et al. A Implementação do Programa Minha Casa Minha Vida na Região Metropolitana do Rio de Janeiro: agentes, processos e contradições. In: SANTO AMORE, Caio. et al. Minha Casa... e a Cidade? Avaliação do Programa Minha Casa Minha Vida em seis estados brasileiros. Rio de Janeiro: Letra Capital, 2015.

CARDOSO, Isabel Cristina. O Papel da Operação Urbana Consorciada do Porto do Rio de Janeiro na Estruturação do Espaço Urbano: uma “máquina de crescimento urbano"?. In: O Social em Questão, ano XVI, nº. 29, 2013, p. 69-100. 
CASTELLS, Manuel. La Urbanización Dependiente en América Latina. In: CASTELLS, Manuel. (Org.). Imperialismo y Urbanización en América Latina. Barcelona: Gustavo Gili, 1973.

CASTRO, Demian Garcia. et al. O Projeto Olímpico da Cidade do Rio de Janeiro: reflexões sobre os impactos dos megaeventos esportivos na perspectiva do direito à cidade. In: CASTRO, Demian Garcia. et al. (org.). Rio de Janeiro: os impactos da Copa do Mundo 2014 e das Olimpíadas 2016. Rio de Janeiro: Letra Capital, 2015.

CHESNAIS, François. Introdução Geral. In: CHESNAIS, François. (org.). A Mundialização Financeira: gênese, custos e riscos. São Paulo: Xamã, 1998.

O Capital Portador de Juros: acumulação, internacionalização, efeitos econômicos e políticos. In: CHESNAIS, François. (org.). A Finança Mundializada. São Paulo: Boitempo, 2005.

COMPANS, Rose. Barra da Tijuca em números: um estudo sobre o licenciamento de construções nos anos 2000 e 2001. In: Coleção Estudos Cariocas. Secretaria Municipal de Urbanismo: Rio de Janeiro, 2002.

DUAYER, Mário e ARAÚJO, Paulo Henrique. Para a Crítica da Centralidade do Trabalho: contribuição com base em Lukács e Postone. Revista Em Pauta, Rio de Janeiro, $1^{\text {o }}$ Sem. 2015, n'. 35, v. 13, pp. 15- 36.

ENGELS, Friedrich. Sobre a Questão da Moradia. São Paulo: Boitempo, [1872] 2015.

FAULHABER, Lucas. Jogo Imobiliário Carioca. Dissertação de mestrado. IPPURUFRJ. Rio de Janeiro, 2016.

FERNANDES, Nélson. O Rapto Ideológico da Categoria Subúrbio: Rio de Janeiro 1858-1945. Rio de Janeiro: Apicuri, 2011.

FIORI, José Luis. Os Moedeiros Falsos. Petrópolis: Vozes, 1997.

FIX, Mariana. Financeirização e Transformações Recentes no Circuito Imobiliário no Brasil. Tese de doutorado. IE-UNICAMP. Campinas, 2011. 
FRANCO, Marielle. UPP - A Redução da Favela a Três Letras: uma análise da política de segurança pública do estado do Rio de Janeiro. Dissertação de mestrado. PPGAdUFF. Niterói, 2014.

GORENDER, Jacob. Globalização, Tecnologia e Relações de Trabalho. In: Revistas Estudos Avançados, v. 11, no. 29, pp. 311-361. São Paulo: IEA/USP, 1997.

HALFEN, Vitor. Porto Maravilha e a Alienação do Trabalho do Arquiteto. Trabalho Final de Graduação. FAU-UFRJ. Rio de Janeiro, 2014.

HARVEY, David. Paris, Capital da Modernidade. São Paulo, Boitempo, 2015. . Os Limites do Capital. São Paulo: Boitempo, 2013. . A Produção Capitalista do Espaço. São Paulo: Annablume, 2005.

JARAMILLO, Samuel. Las Formas de Producción del Espacio Construido en Bogotá. In: PRADILLA, Emilio. (Org.). Ensayos sobre el problema de la vivienda en México. México: Latina UNAM, 1982. pp. 149-212.

LAPAVITSAS, Costas. Theorising Financialisation. In: Work, Employment \& Society, v. 25, nº. 4, pp. 611-626, 2011.

LEFEBVRE, Henri. A Revolução Urbana. Belo Horizonte: Editora UFMG, [1970] 1999.

. A Cidade do Capital. Rio de Janeiro: DP\&A Editora, [1972] 1999. . Espaço e Política. Belo Horizonte: Editora UFMG, [1972] 2008. . O Direito à Cidade. São Paulo: Centauro, [1968] 2010.

LENCIONI, Sandra. Metropolização do Espaço: processos e dinâmicas. In: FERREIRA, Álvaro. et al (org.). Metropolização do Espaço: gestão territorial e relações urbano-rurais. Rio de Janeiro: Consequência, 2013.

- Metrópole e sua Lógica Capitalista Atual Face ao Regime de Acumulação Patrimonial. Revista Mercator, v. 14, nº.4. Fortaleza, 2015, p. 149-158. 
. Metrópole, Metropolização e Regionalização. Rio de Janeiro:

Consequência, 2017.

LIMA JR., João. IPO's das Empresas Brasileiras de Real Estate: a questão da Valuation. In. Seminário Internacional da Latin America Real State Society. São Paulo, agosto de 2007.

MARICATO, Ermínia. Para Entender a Crise Urbana. São Paulo: Expressão Popular, 2015.

MARTINS, José de Souza. O Cativeiro da Terra. São Paulo: Livraria Editora Ciências Humanas, 1979.

MARX, Karl. O Capital: crítica da economia política. Livro I. São Paulo: Boitempo, [1867] 2013.

O Capital: crítica da economia política. Livro III. São Paulo: Boitempo, [1894] 2017.

Teorias da Mais-Valia: história crítica do pensamento econômico.

Vol. 1. Rio de Janeiro: Civilização Brasileira, 1980.

. Teorias da Mais-Valia: história crítica do pensamento econômico.

Vol. 2. Rio de Janeiro: Civilização Brasileira, 1980.

MASCARO, Alysson. Estado e Forma Política. São Paulo: Boitempo, 2013.

MORAES, Antônio. e COSTA, Wanderley. A Valorização do Espaço. São Paulo: Hucitec, 1984.

MUÑOZ, Francesc. Urbanalización: paisajes comunes, lugares globales. Barcelona: GG, 2008.

NETTO, José Paulo. Introdução ao Estudo do Método de Marx. São Paulo: Expressão Popular, 2011.

OLIVEIRA, Francisco de. Crítica à Razão Dualista. $4^{\mathrm{a}}$ ed. São Paulo: Boitempo, [1972] 2013. 
PAULANI, Leda. A Inserção da Economia Brasileira no Cenário Mundial: uma reflexão sobre a situação atual à luz da história. Boletim de economia e política internacional, nº10. Brasília: Ipea, 2012.

PENHA FILHO, Carlos Alberto e MIOTO, Beatriz. Limites da Concentração e Centralização de Capitais no Imobiliário: um olhar a partir de quatro empresas incorporadoras. In: anais do XVII Enanpur. São Paulo, 2017.

PEREIRA, Paulo C. Xavier. Espaço, Técnica e Construção: o desenvolvimento das técnicas construtivas e a urbanização do morar em São Paulo. São Paulo: Nobel, 1988.

Dinâmica imobiliária e Metropolização: a nova lógica do crescimento urbano em São Paulo. Scripta Nova. Revista electrónica de geografía y ciencias sociales. v. 9, nº 194 (10). Barcelona: Universidad de Barcelona, 2005.

Metropolização, Reestruturação Imobiliária e Reconfiguração da Cidade de São Paulo. In: FERREIRA, Álvaro. et al (org.). Metropolização do Espaço: gestão territorial e relações urbano-rurais. Rio de Janeiro: Consequência, 2013.

Preço e Valor na Financeirização da Produção do Espaço. In: FERREIRA, Álvaro. et al (org.). O Espaço e a Metropolização: cotidiano e ação. Rio de Janeiro: Consequência, 2017.

RIBEIRO, Luiz C. Queiroz. Dos Cortiços aos Condomínios Fechados: as formas de produção da moradia na cidade do Rio de Janeiro. Rio de Janeiro: Civilização Brasileira, 1997.

ROYER, Luciana. Financeirização da Política Habitacional: limites e perspectivas. Tese de Doutorado. FAU-USP. São Paulo, 2009.

RUFINO, Maria Beatriz Cruz. Incorporação da Metrópole: centralização do capital no imobiliário e nova produção do espaço em Fortaleza. Tese de Doutorado. FAU-USP. São Paulo, 2012.

. A Incorporação da Metrópole: algumas considerações sobre a produção imobiliária e a metropolização. In: FERREIRA, Álvaro. et al (org.). 
Metropolização do Espaço: gestão territorial e relações urbano-rurais. Rio de Janeiro: Consequência, 2013.

. Um Olhar Sobre a Produção do PMCMV a Partir de Eixos Analíticos. In: SANTO AMORE, Caio. et al. Minha Casa... e a Cidade? Avaliação do Programa Minha Casa Minha Vida em seis estados brasileiros. Rio de Janeiro: Letra Capital, 2015.

Financeirização do Imobiliário e Transformações na Produção do Espaço. In: FERREIRA, Álvaro. et al (org.). O Espaço e a Metropolização: cotidiano e ação. Rio de Janeiro: Consequência, 2017.

RUFINO, Maria Beatriz Cruz. e PEREIRA, Paulo C. Xavier. Segregação e Produção Imobiliária na Transformação da Metrópole Latino-americana: um olhar a partir da cidade de São Paulo. In: LENCIONI, Sandra. et al. Transformações Sócio-Territoriais nas Metrópoles de Buenos Aires, São Paulo e Santiago. São Paulo: FAU-USP, 2011.

SANFELICI, Daniel. Financeirização e a Produção do Espaço Urbano no Brasil: uma contribuição ao debate. EURE, v.39, nº118, setembro/2013a.

A Financeirização do Circuito Imobiliário como Rearranjo Escalar do Processo de Urbanização. Confins: Revista franco-brasileira de geografia [online], $\mathrm{n}^{\mathrm{o}} .18,2013 \mathrm{~b}$.

SANTOS, Cesar Simoni. Horizontes da política social na globalização da desigualdade e o Minha Casa Minha Vida. Revista Cidades, v. 13, nº. 22, 2016.

SECRETARIA MUNICIPAL DE URBANISMO. Evolução da Ocupação e Uso do Solo: 2014 - 2015 - 2016. Secretaria Municipal de Urbanismo: Rio de Janeiro, 2016.

SHIMBO, Lucia. Habitação Social de Mercado: a confluência entre Estado, empresas construtoras e capital financeiro. Belo Horizonte: C/Arte, 2012.

SMITH, Adam. A Riqueza das Nações: investigação sobre sua natureza e suas causas. São Paulo: Nova Cultural, [1776] 1996. 
SMITH, Roberto. Propriedade da Terra e Transição: estudo da formação da propriedade privada da terra e transição para o capitalismo no Brasil. São Paulo: Editora Brasiliense, 1990.

TAVARES, Rosana. A Estrutura de Financiamento das Empresas Brasileiras Abertas do Setor de Construção Civil Incorporadoras de Empreendimentos Imobiliários: um estudo comparativo. Tese de Doutorado. FEA-USP. São Paulo, 2008.

TONE, Beatriz. São Paulo, Século XXI: valorização imobiliária e dissolução urbana. Tese de Doutorado. FAU-USP. São Paulo, 2015.

TOPALOV, Christian. Les Promoteurs Immobiliers: contribution à l'analyse de la production capitaliste du logement en France. Paris: Editora Mouton, 1974.

VAINER, Carlos. Pátria, Empresa e Mercadoria: notas sobre a estratégia discursiva do planejamento estratégico urbano. In: ARANTES, Otília. et al. A Cidade do Pensamento Único: desmanchando consensos. Petrópolis: Vozes, 2000.

VOLOCHKO, Danilo. Nova Produção das Periferias Urbanas e Reprodução do Cotidiano. In: CARLOS, Ana Fani A. (org.). Crise urbana. São Paulo: Contexto, 2015a.

. A Moradia como Negócio e a Valorização do Espaço Urbano Metropolitano. In: CARLOS, Ana Fani A. et al (orgs.). A Cidade Como Negócio. São Paulo: Contexto, 2015b.

WERNECK, Mariana. Porto Maravilha: agentes, coalizões de poder e neoliberalização. Dissertação de Mestrado. IPPUR-UFRJ. Rio de Janeiro, 2016. 
Institute for Mergers, Acquisitions and Alliances (IMAA):

https://imaa-institute.org/m-and-a-statistics-countries/

\section{Leis Federais:}

Decreto da Alienação Parcial da Propriedade Condominial (Dec. n 5.481/1997): http://www2.camara.leg.br/legin/fed/decret/1920-1929/decreto-5481-25-junho-1928776630-publicacao original-140611-pl.html

Lei das Incorporações Imobiliárias (Lei $n^{0}$ 4.591/1964):

http://www.planalto.gov.br/ccivil_03/LEIS/L4591.htm

Lei do Sistema Financeiro Imobiliário (Lei no 9.514/1997):

http://www.planalto.gov.br/ccivil_03/LEIS/L9514.htm

Estatuto da Cidade (Lei $\mathrm{n}^{\circ}$ 10.257/2001):

http://www.planalto.gov.br/ccivil_03/leis/LEIS_2001/L10257.htm

Lei do Patrimônio de Afetação (LC no 10.931/2004):

http://www.planalto.gov.br/ccivil_03/_Ato2004-2006/2004/Lei/L10.931.htm

Lei do Programa Minha Casa Minha Vida (LC no 11.977/2009):

http://www.planalto.gov.br/ccivil_03/_Ato2007-2010/2009/Lei/L11977.htm

\section{Leis Municipais:}

Normas relativas a edificações do PMCMV no município do Rio de Janeiro (LC $\mathbf{n}^{\circ}$ 97/2009):

http://mail.camara.rj.gov.br/APL/Legislativos/contlei.nsf/10348033358c05b10325681f006 2ca30/9165c07fa1cfeb0083257792005a0c7f?OpenDocument

Plano Diretor de Desenvolvimento Urbano Sustentável do Município do Rio de Janeiro (LC 111/2011): 
http://www.rio.rj.gov.br/dlstatic/10112/139339/DLFE229591.pdf/LeiComplementar11120 11PlanoDiretor.pdf

Lei de Uso e Ocupação do Solo do Município do Rio de Janeiro (PLC no 33/2013):

http://www.rio.rj.gov.br/dlstatic/10112/4224287/4103827/ProjetodeLeiComplementar33_2 013LUOS 